This report has been reproduced directly from the best aysilable copy

Available to DOE and DOE contractors from the Office of Scientific and Technical Information, P.O. Box 62, Oak Ridge, TN 37831; prices available from (615) 576-8401, FTS 626-8401.

Available to the public from the National Technical Information Service, U.S. Department of Commerce, 5285 Port Royal Rd. Springfinld, VA 22161.

NTIS price codes-Printed Copy: AO9 Microfiche AO 1

This report was prepared as an account of weirk sponsored by an agency of the United States Government. Neither the United States Government nor any agency thereof, nor any of their employees, makes any warranty, express or implied, or assumes any legal liability or responsibility for the sccuracy, contpleteness, or usefulness of any information, apparatus, product, or process disclosed, or represents that its use would not intringe privately owned rights. Reference herein to any specific commercial product, process, or service by trade name, trademark, manufacturer, or otherwise, does not necessarily constitute or imply its endorsement, recommendation, or favoring by the United States Government or any agency thereof. The viows and opinions of authors expressed herein do not necessarily state or reflect those of the United States Government or any egency thereof. 


\title{
COMPARATIVE EVALUATION OF SEVERAL SMALL MAMMAL SPECIES AS MONITORS OF HEAVY METALS, RADIONUCLIDES, AND SELECTED ORGANIC COMPOUNDS IN THE ENVIRONMENT ${ }^{1}$
}

\author{
Sylvia S. Talmage ${ }^{2}$ \\ Barbara T. Waiton
}

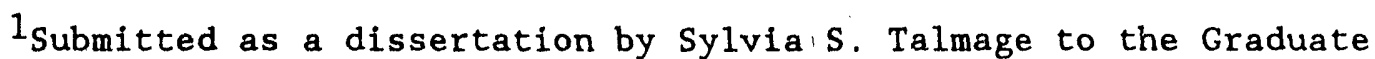
School of The University of Tennessee in partial fulfillment of the requirements for the degree of Doctor of Philosophy.

2Ecology Program, The University of Tennessee, Knoxville; Health and Safety Research Division, Oak Ridge National Laboratory

\author{
Environmental Sciences Division \\ Publication No. 3534 \\ Date Published - August 1990
}

\begin{abstract}
Prepared for the Office of Environmental Restoration and Waste Management, U.S. Department of Energy (Budget Activity No. KG 7291010 )
\end{abstract}

Prepared by the OAK RIDGE NATIONAL LABORATORY

Oak Ridge, Tennessee 37831-6285 operated by MARTIN MARIETTA ENERGY SYSTEMS, INC. for the U.S. DEPARTMENT OF ENERGY under Contract DE-AC05-840R21400 
I. INTRODUCTION . . . . . . . . . . . . . . . 1

II. REVIEW OF THE USE OF SMALL MAMMALS AS MONITORS OF CHEMICAL CONTAMINANTS

Introduction.

Study Species . . . . . . . . . . . . . . . 5

Soricidae . . . . . . . . . . . . . . 5

Cricetidae . . . . . . . . . . . . 9

Muridae . . . . . . . . . . . . . . . . . 13

Other Families . . . . . . . . . . . . . 14

Metal Contaminants . . . . . . . . . . . . . . . . 14

Arsenic . . . . . . . . . . . . 15

Cadmium . . . . . . . . . . . . . 16

Chromium . . . . . . . . . . . 21

Cobalt . . . . . . . . . . . . . . . . 22

Copper . . . . . . . . . . . . . . . . . 22

Lead . . . . . . . . . . . . . . . . 25

Manganese . . . . . . . . . . . . . . . . 31

Mercury . . . . . . . . . . . . . . . . . 32

Nickel . . . . . . . . . . . . 33

Zinc . . . . . . . . . . . . . 34

Radionuclides . . . . . . . . . . . . . . . . . 35

Organic Contaminants . . . . . . . . . . . . . . . . 37

DDT and Metabolites . . . . . . . . . 39

Dieldrin . . . . . . . . . . . . . . 45

Kepone . . . . . . . . . . . . . . . . 46

Mirex . . . . . . . . . . . . . . . . . . . 46

Organophosphate pesticides . . . . . . . . . . 47

Polychlorinated biphenyls . . . . . . . . . . . 48

2,3,7,8-Tetrachlorodibenzo-p-dioxin . . . . . 49

Complex Mixtures . . . . . . . . . . . . . . . 51

Evaluation of Study Species as Monitors . . . . . . 53

Limitations to biomonitoring . . . . . . . . 68

Advantages of biomonitoring . . . . . . . . . . 70

III. BIOMONITORING STUDIES AT ORNL . . . . . . . . . . . . . 72

Introduction . . . . . . . . . . . . . . . . . . . . 72

Materials and Methods . . . . . . . . . . . . 77

Laboratory Study . . . . . . . . . . . . . . . 77

Description of Study Sites . . . . . . . 78

East Fork Poplar Creek. . . . . . . . . 78

White Oak Lake. . . . . . . . . . . . . . 79

White Oak Creek . . . . . . . . . . . . . 80

Solid. Waste Disposal Area-4 . . . . . . . 80

Collection of Study Animals . . . . . . . . . . 83

Collection of Soil Samples . . . . . . . . . 84 


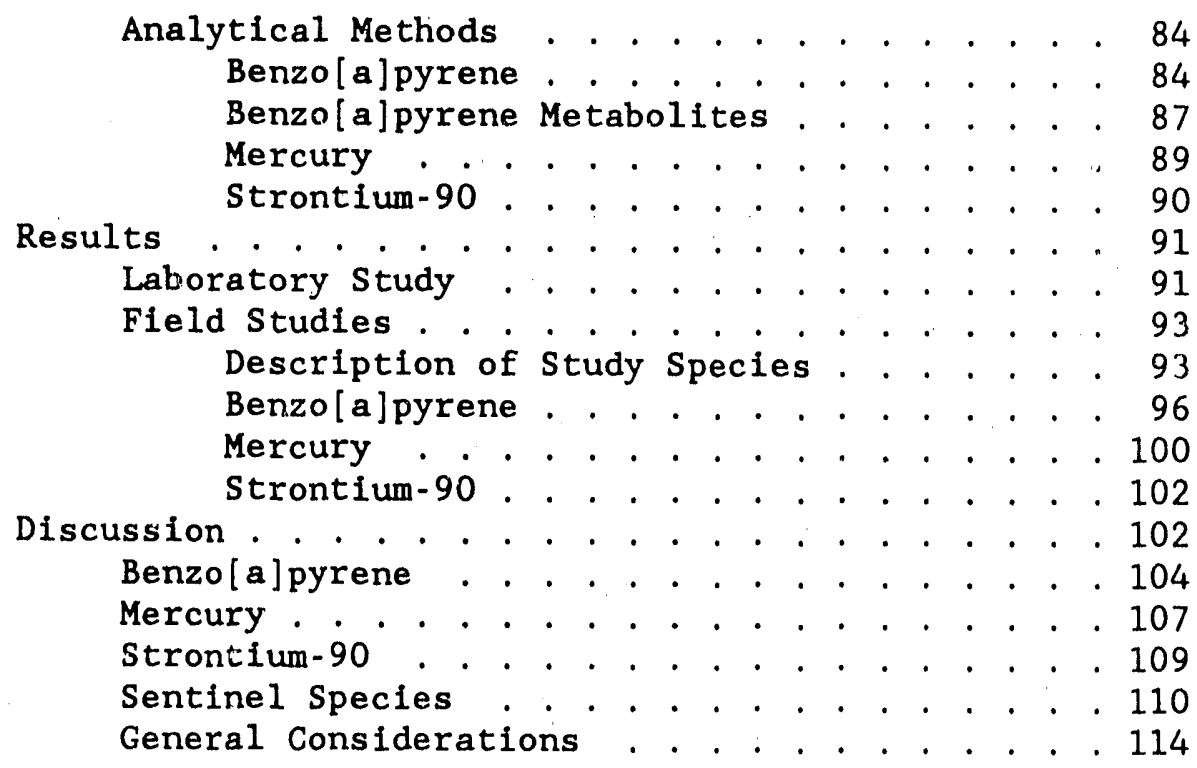

IV. CONCLUSIONS . . . . . . . . . . . . . . . . . . 116

LITERATURE CITED . . . . . . . . . . . . . . . . . . . 119

APPENDICES . . . . . . . . . . . . . . . . . . . 131

APPENDIX A. HEAVY METAL CONCENTRATIONS IN SOIL, VEGETATION, AND TISSUES OF SNIALL MAMMALS AT CONTAMINATED

SITES . . . . . . . . . . . . . . . . 133

APPENDIX B. CONCENTRATIONS OF MERCURY IN KIDNEY TISSUE

OF SMALL MAMMALS AT ORNL . . . . . . . . . . . . 167

APPENDIX C. CONCENTRATIONS OF MERCURY IN SOIL AT ORNL . . . . 171

APPENDIX D. CONCENTRATIONS OF STRONTIUM-90 IN BONES OF

SMALL MAMMALS AT ORNL. . . . . . . . . . . . . 173 
1. Species and common names of small mammals trapped in monitoring studies. . . . . . . . . . . . . . . . . . 6

2. Concentrations of cadmium in tissues of small mammals trapped at control sites . . . . . . . . . . . . . . 18

3. Relationship between concentrations of cadnium in soil and tissues of Apodemus sylvaticus . . . . . . . . . . . 21

4. Concentrations of copper in tissues of small mammals trapped at control sites . . . . . . . . . . . . . . . . 24

5. Tissue and whole-body concentrations of lead in small mammals trapped at control sites . . . . . . . . . . . . 26

6. Relationship between traffic density and tissue concentration of lead in peromyscus leucopus . . . . . . 28

7. Relationship between lead concentrations in soil and tissues of Apodemus sylvaticus . . . . . . . . . . . . . 29

8. Concentrations of zinc in tissues of small mammals trapped at control sites . . . . . . . . . . . . . . . . 35

9. Radionuclide concentrations in carcasses and tissues of small mammals trapped at contaminated and control sites. 36

10. Organic contuminants assayed in small mammals at field and hazardous wàste sites . . . . . . . . . . . . . . . 40

11. Evaluation of small mammal species and target tissues as biomonitors of environmental contaminants . . . . . . . 54

12. Relationship between diet and biomonitoring suitability of small mamials collected at contaminated sites . . . . 69

13. Contaminants present at the East Fork Poplar Creek. (EFPC), White Oak Lake (WOL), White Oak Creek (WCK), and Solid Waste Disposal Area-4 (SWSA-4) study sites . . 84

14. Weekly concentrations of benzo[a]pyrene tetrol I-1 metabolite in the blood of mice fed 3 dose levels of benzo[a]pyrene in the laboratory

15. Species and numbers of smal1 mammals trapped at ORNL study sites during 1986-1988 . . . . . . . . . . . . . . 94 
16. Food habits of species trapped at the ORNL study sites

17. Benzo[a]pyrene concentrations in soil at the East Fork Poplar Creek (EFPC), White Oak Creek (WCK 2.1), White Oak Lake (WOL), and Solid Waste Disposal Area-4 (SWSA.4) sites . . . . . . . . . . . . . . . . . . 97

18. Species of mammals trapped at East Fork Poplar Creek and White Oak Lake and tested for the presence of benzo[a]pyrene metabolites . . . . . . . . . . . . . . . 98

19. Mercury concentrations in soil and kidney tissue of small mammals collected on the East Fork Poplar Creek (EFPC) floodplain, White Oak Creek (WCK) floodplain, and Solf.d Waste Storage Area-4 (SWSA-4) sites . . . . . . 101

20. Strontium-90 concentrations in bone of small mammals, soil, and vegetation from the East Fork Poplar Creek (EFPC) floodplain, White Oak Creek (WCK) floodplain, and Solid Waste Storage Area-4 (SWSA-4) sites.... . . 103

21. Evaluation of three species of smali inammals as monitors of benzo[a]pyrene, mercury: and strontium-90 at the ORNL sites... . . . . . . . . . . . . . . 111 
1. White Oak Creek Floodplain showing the solid waste disposal areas and small mammal trapping sites... . . . 81

2. Solid Waste Storage Area-4 showing ground-1evel gamma readings, the seeps, and small mammal trapping sites . . 83

3. High performance liquid chromatography/fluorescence profiles of (a) standard solution of benzo[a]pyrene tetrols I-1 and II-2, and (b) tetrols hydrolyzed from the hemoglobin of a $\mathrm{C} 3 \mathrm{H}$ mouse following four weeks of treatment with 50 ug of benzo[a]pyrene twice weekly . . . 92

4. High performance liquid chromatography/fluorescence profiles of (a) standard solution of benzo[a]pyrene and (b) organic compounds extracted from the soil at East Fork Poplar Creek . . . . . . . . . . . . . . . . . . . .

5. High performance liquid chromatography/fluorescence profiles of (a) standard solution of benzo[a]pyrene tetrols I- 1 and II-2 and (b) tetrols hydrolyzed from the hemoglobin of Blarina brevicauda trapped at East Fork Poplar Creek . . . . . . . . . . . . . 999 


\section{ACKNOWLEDGEMENTS}

We thank Drs. Walter R. Farkas, Arthur C. Echternacht, and Lee R. Shugart for helpful guidance and critical comment during the course of this study. We especially appreciate the expert advice of Dr. Shugart on the subchronic feeding study and analysis of blood for hemoglobin adducts of benzo[a]pyrene metabolites. Contributions of Ms. Linda Meyers-Schone, Mr. Nelson Edwards, Dr. Tsuneo Tamura, Mr. Brian Keele, Mr. James Stout, Mr. Charles Garten, Dr. Anthony King, and Ms. Theresa Feldkamp of Oak Ridge National Laboratory are gratefully acknowledged. Dr. Barnett Rattner, Patuxent Wildlife Research Center; Dr. Clayton Gist, Oak Ridge Associated Universities; and Dr. Wayne Clark, Oak Ridge, Tennessee, provided helpful assistance.

This research was conducted in the Environmental Sciences Division at Oak Ridge National Laboratory under sponsorship of the Office of Environmental Restoration and Waste Management, U.S. Department of Energy, under contract DE-AC05-840R21400 with Martin Marietta Energy Systems, Inc. 


\section{ABSTRACT}

TALMAGE, S. S. and B. T. WALTON. 1990. Comparative Evaluation of Several Small Mammal Species as Monitors of Heavy Metals, Radionuclides, and Selected Organic Compounds in the Environment. ORNL/TM-11605. Oak Ridge National Laboratory, Oak Ridge, Tennessee.

The merit of using small mammals as monitors of environmental contaminants was assessed using data from the literature and results of a monitoring study at selected sites on the Oak Ridge National Laboratory (ORNL) research reservation operated for the U.S. Department of Energy in Oak Ridge, Tennessee. Heavy metals, radionuclides, and organic chemicals were included in the evaluations. In the literature review, exposure to contaminants was determined from tissue residue concentrations, biochemical assays, and cytogenetic assays. In general, there was a relationship between concentrations of contaminants in the soil and concentrations in target tissues of several species. This relationship was most obvious for the nonessential heavy metals, cadmium and lead.

Each species' suitability as a monitor for a specific contaminant or type of contaminant was evaluated and subsequently ranked. A relationship between contaminant uptake and trophic level emerged. Carnivores had the highest concentrations of contaminsints, followed by omnivores and herbivores which had the lowest concentrations. Target tissues for specific contaminants were also ranked.

In the field study, ten species of small mammals were trapped at selected field and reference sites to monitor for exposure to mercury, strontium-90, and benzo[a]pyrene. Residue anasyses and a hemoglobinadduct assay were performed on several species including the shorttail 
shrew (Blaxina brevicauda), the white-footed mouse (Peromyscus leucopus), and the cotton rat (Sigmodon hispidus).

Accumulation of mercury in kidney tissue and strontium-90 in bone was related to the degree of contamination of the environment as well as trophic level of the species. Both shorttail shrews and whitefooted mice trapped at the mercury-contaminated site had significantly higher concentrations of mercury in kidney tissue than those irapped at the reference sites. However, the mean concentration in kidnoy of the insectivorous shrew was nearly 33 times that of the omnivorous mouse.

Strontium-90 was present in the bone of all species trapped at the radionuclide-contaminated sites, but was highest in the herbivore, Reithrodontomys humulis, which inhabited the grassy site. For the white-footed mouse, there was a gradient effect of strontium-90 accumulation among the highly contaminated, intermediate, and uncontami. nated sites.

The hemoglobin-adduct assay was evaluated as an indicator of subchronic exposure to benzo[a]pyrene in the laboratory and chronic exposure in the field. Concentrations of benzo[a]fjrene-hemoglobin adducts in $\mathrm{C} 3 \mathrm{H}$ mice fed benzo[a]pyrene in the laboratory for seven weeks were initially high, but declined to low, barely detectable, levels with time. Concentrations of benzo[a]pyrene-hemoglobin adducts in small mammals exposed to low concentrations of benzo[a]pyrene in the field were low and variable among individuals and between species. 


\section{INTRODUCTION}

Many potentially harmful chemicals, both natural and anthropogenic, are released to the environment each year. Although chemical analyses of soll, air, and water can tell us the concentrations of specific compounds present, they are Inadequate to assess the availability and potential toxicity of contaminants to humans and other biota. These analytical techniques do not take into account critical properties that determine bioavaliability of contaminants such as media-chemical interactions and the physiology and biochemistry of the organism. Moreover, toxicity assays conducted in the laboratory with single chemicals fail to account for the complexity of chemical mixtures encountered by animals inhabiting contaminated sites and, therefore, cannot be readily extrapolated to field situations. Animals that live in these environments, however, integrate contaminant exposure both spatially and temporally. Therefore, measurement of chemical contaminants and their metabolites, in vivo reaction products, and effects within the organism hold promise as a means of identifying and estimating human health risks from natural populations of animals.

Resident wildlife populations at contaminated sites can be used as surrogates for human exposure and as monitors of adverse effects on the populations themselves. Small mammals have frequently been used to monitor the presence of metals and other chemical contaminants in the environment, either directly, based on residue analysis, or indirectly, based on biochemical parameters. Small mammals can be particularly effective biomonitors of soll contaminants if the species used are abundant, easily caught, do not migrate long distances, have wide- 
spread distribution, and have generalized food habits (Beardsley et al. 1978). Good biomonitors are in equilibrium with the contaminant of interest and ideally show a graded response to a range of pollution. Their relatively short life span (generally less than one year) allows long-term monitoring of contaminants in that each new generation reflects the present type and amount of contaminants in the environment, thus increases, decreases, or the addition of new contaminants can be detected. Thus, small mammals can serve as indicators of the presence and bioavaliability of chemical contaminants, and selected species can be used to measure bioaccumulation. Furthermore, knowledge of food habits and habitat may indicate routes of exposure to animals. Biological monitoring can be used as a cost-effective survey of contaminated sites, for routine surveillance of uncontaminated sites, to provide evidence for contaminant impacts on biota, and to establish priorities for site cleanup. In preliminary studies to determine the extent of contamination, biomonitoring can be used as an alternative to extensive sampling and chemical analyses of abiotic media, particularly where a large area is involved and the origin or extent of contamination is unknown. In uncontaminated areas, where there is a potential. for contamination via accidental release or migration of contaminants, small mammals can be routinely monitored over long periods of time. Since the presence of a contaminant does not necessarily involve risk to humans, evidence of impact on biota as determined by biochemical parameter changes and tissue residues will help to estabilish the need for site cleanup. 
The primary purpose of this study was to evaluate which small mammal species are the best monitors of specific environmental contaminants. The evaluation is based on the published literature and on an analysis of small mammals trapped at several sites on the Oak Ridge National Laboratory (ORNL) Reservation in Oak Ridge, Tennessee. Studies on the uptake of heavy metals, radionuclides, and organic chemicals are reviewed in Chapter II to evaluate several small mamma] specier for their capacity to serve as sentinels for the presence, accumulation, and effects of various contaminants. Where several species were present at a site, a comparative evaluation was made and species are rankel for their capacity to serve as monitors of specific contaminants. Food chain accumulation and food habits of the species are used to establish a relationship with suitability as a biomonitor. In addition, tissue-specific concentration factors were noted in order to establish target tissues. Life histories, habitat, and food habits are reviewed in order to make genoralizations concerning the ability of similar taxa to serve as biomonitors. Finally, the usefulness of several small mammal species as monitors of three contaminants - benzo[a]pyrene, mercury, and strontium-90 -- present on or near the ORNL facilities was investigated. Sentinel species for these contrminants are discussed in terms of the conclusions drawn from the literature review. This study is presented in Chapter III. 
II. REVIEW OF THE USE OF SMALL MAMMALS

AS MONITORS OF CHEMICAL CONTAMINANTS

\section{Intreduction}

The earliest biomonitoring scudies, reported in the early 1970s, involved meastrement of metals and persistent organic compounds in tissues and whole bodies of animals collected after accidental releases of contaminants or field application of chemical pesticides. Most of these residue analyses made no al:tempt to relate tissue concentrations to potential health effects. Studies performed within the last six years have tried to document health effects $d=$ sites where complex mixtures of chemicals are present.

Heavy metals are the most commonly evaluated environmental contaminants in biomonitoring studies. Studies on heavy metals are of several types: (1) reports of metal concentrations in animals from only one location, (2) correlations of tissue concentrations with environmental concentrations, (3) monitoring a site through time, (4) concentrations in animals collected along a gradient of pollution, and (5) comparisons of concentrations in animals from reference and contaminated sites or sites where contamination is suspected. These studies provide information on background concentrations of contaminants and correlations of tissue concentrations with environmental concentrations. 


\section{Study Species}

In order to evaluate species-specific uptake of contaminants, information on the diet, habitat, and activity of the monitored species is necessary. The selection of an appepriate or optimal species for a monitoring study is restricted to those present at a site. When the ideal species in not present at a specific site, closely related species or a species occupying a similar niche may be used. Alternatively, a particular species, known to be a good biomonitor, can be placed in enclosures at the site and the uptake or effect of the contaminants can be compared to that at a reference area. Life history information on the genera and species most often discussed in the literature is provided here. The most commonly trapped small mammals belonged to three families: Soricidae (shrews), Cricetidae (mice, rats, lemmings, and voles), and Muridae (Old World mice and rats). Al1 small mammal species discussed in the literature review are listed in Table 1 .

Soricidae (shrews)

Blarina brevicauda, the shorttail shrew, occurs throughout most of the eastern half of the United States and the southern regions of adjacent Canadian provinces (Hall 1981, George et al. 1986). In East Tennessee this species occupies areas with high log and stump density, hard ground, few shrubs, and dense overstory (Kitchings and Levy 1981). Blarina brevicauda nests undergroind; runways usually parallel the surface and are located in the top ten $\mathrm{cm}$ of soil. They also burrow through rotten logs and often use the runways of other rodents. The 
Table 1. Species and common names of small mammals trapped in monitoring studies.

Soricidae

Blarina brevicauda (Say)

Sorex araneus (Linnaeus)

Sorex cinereus (Baird)

Cryptotis parva (Say)

Microsorex hoyi (Zimmermann)

Cricetidae

Reithrodontomys humulis (Audubon and Bachman)

Reithrodontomys megalotis (Baird)

Peromyscus leucopus (Rafinesque)

Peromyscus maniculatus (Wagner)

Peromyscus polionotus (Wagner)

Sigmodon hispidus (Say and Ord)

Microtus pennsylvanicus (Ord)

Microtus pinetorum (LeConte)

Microtus ochrogaster (Wagner)

Microtus agrestis (Linnaeus)

Microtus arvalis (Pallas)

Clethrionomys, glareolus (Schreber)

Clethrionomys gapperi (Vigors)

oryzomys palustris (Harlan)

Muridae

Apodemus sylvaticus (Linneaus)

Mus musculus (Linnaeus)

Rattus norvegicus (Berkenhout)

Rattus rattus (Linnaeus)

Rattus exulans

Zapodidae

Zapus hudsonius (Zimmerman)

Sciuridae

Spermophilus richardsoni (Sabine)

Spermophilus variegatus (Erxleben)

Spermophilus columbianus (Ord)

Spermophilus tridecemlineatus (Mitche11)

Sciurus carolinensis (Gmelin)

Talpidae

Talpa europea (Linnaeus) northern shorttail shrew

common shrew

masked shrew

least shrew

Hoy's pigny shrew

eastefn harvest mouse

western harvest mouse

white-footed mouse

deer mouse

oldfield mouse

hispid cotton rat

meadow vole

pine vole

prairie vole

field vole

common vole

bank vole

Gapper's red-backed vole

marsh rice rat

field mouse

house mouse

Norway rat

black rat

Polynesian rat

meadow jumping mouse

Richardson's ground squirrel rock squirrel

Columbian ground squirrel

13-1ined ground squirrel

gray squir:el

mole 
home range averages 2.5 ha. Earthworms are the major diet item, but millipedes, Insects and occasionally mice and voles are also eaten. In a population from New Brunswick, Canada, the major diet items by volume were earthworms (328), slugs and snails (228), insect larvae (19.58), and adult insects (16.58) (Whitaker and French 1984). Most shrews eat the equivalent of their body weight in food per day $(8 \mathrm{~g})$. In the northern part of their range, the breeding season lasts from early February to September. Gestation requires 21 to 22 days and weaning occurs by 25 days after birth. Litter size is four to six. Life-span is approximately one year. Population density varies from year to year and populations occasionally crash (George et al. 1986). Depending on the quality of the habitat, density varies from 3 to $30 /$ ha. In the wild, $\underline{B}$. brevicauda is a solitary territorial species (Nowak and Paradiso 1983). Blarina brevicauda can be distinguished from other shrews by its short tall and slate gray color. This species was trapped in several studies cited in the literature review and at ORNL.

Sorex araneus, the common shrew, is found over most of Europe except for Ireland and parts of the Iberian peninsula (van den Brink 1968). This species is commonly found in various types of habitats: woods, grasslands, marshlands, dunes, and open areas. Sorex araneus is active day and night, tunneling through the loose accumulation of litter and also burrowing underground in search of food. In England, S. araneus occupies a well-defined home range of approximately $2,800 \mathrm{~m}^{2}$ and is aggressive toward other members of its species (Nowak and Paradiso 1983). Like most shrews, it eats approximately its own body weight $(8 \mathrm{~g})$ of food per day. Adult Coleoptera and Lumbricidae are the 
dominant prey in the average diet, with insect larvae, harvestmen (Phalangids), slugs and snails also important (Rudge 1968, Pernetta 1976). Seasonal fluctuations in diet occur, depending on prey avaliability. The nest is usually above ground and under cover. Sorex araneus occupies a niche similar to that of $\underline{B}$. brevicauda in the United States (Quarles et al. 1974).

Sorex cinereus, the masked shrew, is widely distributed over Canada and the northern United States with southern extensions in the mountain areas (Burt, 1976). It is found in moist situations in forests, open country, and brushland. This small, long-talled shrew eats more than its own weight in food each day. A nest of dry leaves is bujilt under trees, logs, or brush. Another member of the family Soricidae, the least shrew, Cryptotis parva, is found in grass-covered areas throughout the southeastern United States (Whitaker 1974), largely overlapping the distribution of $\underline{B}$. brevicauda. Although not commonly trapped, there is a surprising amount of information concerning predation on this species, especially by owls. Cryptotis parva inhabits grassy, weedy, and brushy fields. It eats earthworms, snails, beetles, and spiders.

Although the Soricidae are found throughout most of North America, shrews were not commonly trapped in monitoring studies. The reasons for low trapping success were not discussed in the 1iterature, but could be due to low numbers and lack of suttable trap bait. Traps were usually baited with seeds or oatmeal, whereas, all shrews are insectivorous. Their solitary and territorial, aggressive habits may also account for low densities. 
Cricetidae (mice, rats, and voles)

The subgenus Reithrodontomys (harvest mice) consists of ninis species (Spencer and Cameron 1982), four of which are distributed across slightly overlapping sections of the United States (Burt 1976). These very small brown mice resemble house mice, but can be distinguished from other mice by their grooved upper incisors. The eastern harvest mouse, $\underline{R}$ humulis, is the only species found in the southeast. It inhabits old fields, marshes, and wet meadows (Burt 1976). In monitoring studies the eastern harvest mouse was trapped only at ORNL. The western harvest mouse, $\underline{\mathrm{R}}$. megalotis, is found from the Great Lakes to the Pacific coast. Grasslands provide habitat where seeds and insects are the primary food items. Nests are usually on or above the surface of the ground (Burt, 1976).

Burt (1976) describes 14 species of Peromyscus distributed throughout North America. The deer mouse $\underline{P}$. maniculatus, has a broader distribution than $\underline{P}$. leucopus, the white-footed incuse, and overlaps with this species over much of its range. Severel of tiiese closely related species have s'milar food habits but slightly different habitat requirements (Brown 1964).

Peromyscus leucopus is distributed from southern Canada through the eastern half of the United States to (ilorado and Mexico. The habitat of $\underline{P}$. leucopus is primarily brushy fields and deciduous woodlands, although it is also present in open, swampy areas (Kitchings and Levy, 1981; lackey et al., 1985). Individuals occupy nest sites above the ground or at ground level in rock piles, logs, stumps, under trees, and in ground burrows. Home range varies seasonally, but 
averages 0.1 ha. Peromyscus leucopus is an opportunistic feeder -. seeds, insects, and green vegetation comprise most of the diet (Brown 1964). Litter size averages four, with several litters per year. Gestation time is 22 to 32 days, and young are weaned after 20 days. In the southern part of its range, the breeding season is year round. Life span in the wild is probably one year. Peromyscus leucopus was trapped in several monitoring studies and was abundant at ORNL.

Sigmodon hispidus, the cotton rat, is found throughout most of the southeastern and southcentral United States (Cameron and Spencer 1981). It commonly occurs in grass-dominated habitats where it nests in burrows or in dense clumps of grass or brush. Home range averages 0.35 ha for the species, however, males range further than females. Home ranges of the latter do not overlap. Cotton rats feed almost exclusively on grasses; seasonal consumption of insects is a notable exception. In warmer parts of their habitat, breeding occurs year round. Litter size varies from one to fifteen with a mean size of four to five. Gestation lasts 27 days; weaning takes place at 10 to 15 days; maturation occurs at one to three months. This species was trapped in several monitoring studies and at ORNL.

Microtus spp. (voles) are found throughout Canada and the United States in areas of good grass cover. Burt (1976) lists 16 species of Microtus, including the pine vole, which is often placed in the genus Pitymys. According to the literature, the most widely distributed and commonly caught species are the meadow vole (ㅆ. pennsylvanicus), the prairie vole (․․ ochrogaster), and the pine vole (ㅆ. pinetorum). Voles may be active day and night, and serve as food for larger predators. 


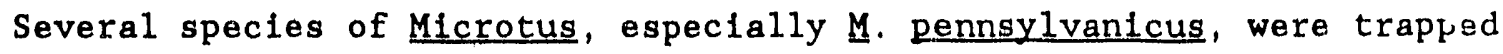
in monitoring studies; both $\underline{M}$. ochrogaster and $\underline{M}$. pinetorum were trapp :d at ORNL, but were not abundant.

Microtus permsylvanicus is found in low, noist meadows and in high grasslands with abundant vegetation throughout Canada and in the northern and eastern United States (Reich 1981). It is often present in orchards with grassy undergrowth. The meadow vole is sympatric with several other species of small mammals. Nests are built above or below ground with runways along the surface of the ground. Voles are active any time of the day. Meadow voles are primarily herbivorous, eating grasses, sedges, seeds, grains, bark, and occasionally insects. The home range is one-tenth to one acre. Populations fluctuate with two to five year intervals. Life span in the wild is one to three years. Breeding is year-round.

Microtus pinetorum, the pine vole, is found in the eastern half of the United States in a wide variety of habitats including deciduous forests, meadows, and orchards where densities may be quite high (Smolen 1981). Nests occur beneath tree roots or stumps and surface burrows are constructed through the loose litter or as shallow surface burrows. Pine voles are primarily herbivorous, eating the sprouts, fruit, and roots of grasses, wild flowers and many economically important crops. The home range is limited to the burrow system. As is the case with $\underline{M}$. pennsylvanicus, populations fluctuate widely from year to year.

Microtus agrestis, the short-tailed vole, is found in moist areas in Northern Europe except for Ireland; it is missing from most of 
Southern Europe (van den Brink 1968). The primary habitats are pastures, flelds, and open woods; rarely are they found under closed canoples. Although the burrow system of this species is underground, the runways occur above ground. The nest is usually above ground, also. Short-tailed voles, which are exclusively herbivorous, feed on above ground vegetation such as the shoots and leaves of fine-leaved grasses (Evans 1973). According to Quarles et al. (1974), a garestis occupies a niche similar to that of the North American species $M$. pennsylvanicus.

Redback voles, Clethrionomys spp., are found in forested areas in both North America and Europe. Clethrlonomys glareolus, the bank vole, is found in the British Isles and most of Europe except for a crescentshaped area around the Mediterranean Sea (van den Brink 1968). The bank vole is found mainly in dectduous woods, but also in hedges, bushes, edges of woods, and parkland. Most authors noted that this species was trapped almost exclusively in areas with cover. of $39 \mathrm{C}$. glareolus trapped by Jefferies et al. (1973), 38 were caught on fleld edges, hedges, dike and grass borders; only one was caught on a tilled field. Superficial burrow systems are built in dry areas. This species is active during the night, but often spends time above ground during the day. Populations are known to fluctuate periodically. As an herbivore, this species feeds primarily on the seeds and leaves of perennial trees and shrubs (Watts 1968, Jefferies and French 1972). Leaves of woody plants, Including dead leaf material during the winter, make up a large portion of the diet during most of the year; insects are eaten only when they are abundant. 
A related species, the Gapper's redbark vole, Clethrlonomys gapperi, is found in Canada and parts of the northern United States, extending south into the Rocky and Appalachian Mountains (Merritt 1981). This red-backed vole is an omnivorous, opportunistic feeder, with diet reflecting availability of foods. The primary diet item is vegetation, with fung1, seeds, and arthropods eaten seasonally. Clethrionomys gapperi occupies forest habitat with abundant 1itter; it may also be found in clear-cut areas and old fields.

Family Muridae (01d World mice and rats)

Apodemus sylvaticus, the wood mouse, is distributed throughout Europe except for part of the Baltic countries (van den Brink 1968). It is abundant in open country and woodland, and in Britain is common to a variety of habitats including tilled fields, grassy areas, hedge rows, woods, and dunes (Kikkawa 1964, Jefferies et a1. 1973). The wood mouse digs shallow burrows, but occasionally builds nests above ground. Like most Muridae, it does not hibernate. It is primarily a nocturnal forager, feeding on grass, seedlings, buds, fruit, nuts, snalls, and insects. Seeds (endosperm) are the most important food item year round, with insects and earthworms eaten in appreciable quantities in spring and a small amount of green leaves in early spring (Watts 1.968). It ranges widely in hedge and field habitats, and occasionally changes its home range area (Kikkawa 1964, Pollard and Relton 1970). Quarles et al. (1974) point out that the habitat and omnivorous food haits of the wood mouse put it in a similar niche to the North American species P. leucopus. Apodemus sylvaticus was the most commonly trapped sma11 mammal in British monitoring studies. 
The only species of old world Muridae found in the United States, Mus musculus, Rattus norvegicus, and Rattus rattus are closely assoclated with man and his dwellings and are rarely found in open fields (Burt 1976, van den Brink 1.968). These species do not hibernate. Al1 three of these species are prolific, breeding year round and are often found in colonial nests. They are omnivorous, eacing anything edible. Members of the family Muridae were rarely collected in monitoring studies except in urban areas. Both us musculus and Rattus norvegicus were present at ORNL, but were not abundant.

Other Families

The meadow jumping mouse (Zapus hudsonius) was trapped in only one study (Smith and Rongstad 1982). This omnivorous specles is found in various types of habitats, but usually feeds in low meadows (Burt 1976). Its distribution includes southern Canada and the north-central and northeastern United States. Squirrels and chipmunks (Sciuridae) and moles (Talpidae) were not commonly trapped in numbers large enough to draw conclusions about monitoring suitability.

\section{Metal Concaminants}

A search of the literature revealed 33 studies that addressed the use of small mammals as monitors of environmental metal contamination (APPENDIX A). A11 of these studies used tissue or whole-body residue analyses as a measure of contaminant exposure. Whole-body and tissue concentrations for both reference and contaminated sites are listed. In addition, concentrations in soil, vegetation, and invertebrates, when avallable, are also provided. 
In order to compare tissue concentrations of metals among studies, all concentrations were converted to dry welght using the conversion factors of several researchers as well as those develuped by the authors during the present study. Jefferies and French (1972) dried liver and body samples of three species at $90^{\circ} \mathrm{C}$ for 72 hours in order to obtain water content. The resulting multiplication factors, used to convert wet weight concentications to dry weight concentrations, were $3.48,3.67$, and 3.40 for liver tissue of $\underline{M}$. agrestis, $\underline{C}$. glareolus, and A. sylvaticus, respectively. Multiplication factors for whole bodies were $3.00,3.16$, and 3.20 for the three species, respectively. According to Roberts and Johnson (1978) and Roberts et al. (1978), multiplication factors for freeze-dried whole bodies of $\underline{M}$. agrestis, $\underline{A}$. sylvaticus, and $\underline{s}$ araneus were $3.09,3.10$, and 3.09 , respectively. For oven-dried samples of muscle, bone, liver, and kidney of $\underline{R}$. norvegicus, conversion factors were $2.38,1.33,2.70$, and 2.08 , respectively (Way and Schroder 1982). Wet weight to dry weight conversion factors for kidneys of species trapped on the ORNL reservation were 2.50 for $\underline{R}$. humulis $(n-3)$ and 3.53 for $\underline{P}$. leucopus $(n-3)$, and S. hispldus $(n-2)$. These values were obtained by drying paired kidneys to a constant weight at $100^{\circ} \mathrm{C}$. For species for which no information was available, the average conversion factors of 3.12 for whole body and 3.5 for soft tissues were used.

Arsenic

Very few studies addressed the relationship between arsenic (a nonessential element) concentrations in soil and vegetation and concentratiors in small mammals. Whole-body concentrations in two 
species from $r \ni$ ference sites were $\leq 1$ ug/g (Smith and Rongstad 1982). Concentrations in tissues of small mammals at reference and leadarsenate-treated orchards were not given, but concentrations in soil were 3 and $31 \mathrm{ug} / \mathrm{g}$, respectively (Elfving et al. 1978, Haschek et al. 1979). Of seven crops sampled at the orchards, arsenic was concentrated by a factor of seven in carrots and millet from the orchard soil compared to the corresponding crops at the reference site. It was not concentrated over the soil value in several other crops. Too little animal tissue was available to analyze for arsenic at this site. Sharma and Shupe (1977) found no relationship between arsenic concentrations in soil and vegetation and concentrations in the livers of rock squirrels (Spermophilus variegatus) from different uncontaminated areas in the western United States. The mean arsenic concentration in five composite samples of Peromyscus maniculatus from a zinccopper mine was not different from that of reference animals $\quad<0.1$ ug/g) (Smith and Rongstad 1982). However, two composite samples of Blarina brevicauda from this site did show a difference; whole-body concentrations at the reference and mine sites were $<0.1$ and $0.6 \mathrm{ug} / \mathrm{g}$, respectively. Soil and vegetation concentrations were not given. No conclusions concerning uptake or sentinel species could be made from these few studies.

Cadmium

Cadmium is usually found in mineral ores in association with other metals such as lead, zinc, and copper. Extraction and separation of the heavy metals results in extensive metal contamination in the vicinity of mine sites and smeltering operations. In uncontaminated 
areas, cadmium is present in the earth's crust at an average concentration of $0.2 \mathrm{ug} / \mathrm{g}$ (Hammond and Beliles 1980). Cadmium concentrations of $0.8,1$, and $2 \mathrm{ug} / \mathrm{g}$ were measured in soil at reference sites in the monitoring studies cited in Table 2. In the following studies analysis for cadmium was by atomic absorption spectroscopy.

Whole-body concentrations of cadmium in most species of small mammals from reference sites averaged $<1 \mathrm{ug} / \mathrm{g}(0.1$ to $1.4 \mathrm{ug} / \mathrm{g})$ (Table 2). Shrews averaged slightly higher than other animals, ranging from 1.2 to $4 \mathrm{ug} / \mathrm{g}$. Except for two studies, concentrations in liver and kidney of most animals ranged from $<0.1$ to 1.3 and 0.0 to $5 \mathrm{ug} / \mathrm{g}$, respectively. Reasons for the high concentrations in $\underline{S}$. araneus at the reference site in one study (Hunter and Johnson 1982) and Talpa europa (mole) in mother study (Ma 1987) are not possible to ascertain. Many of the data points in Table 2 are based on only one or two studies. In general, there was a positive relationship between concentrations of cadmium in soil and concentrations in soft tissues of small mammals. Several species were trapped at the most highly contaminated site, a derelict lead-zinc inine in Wales, where cadmium concentrations in the surrounding surface soll averaged $92 \mathrm{ug} / \mathrm{g}$ (Johnson et al. 1978, Roberts and Johnson 1978). Whole-body and/or tissue levels were higher at the mine site than the reference site for four species trapped: $\underline{A}$.

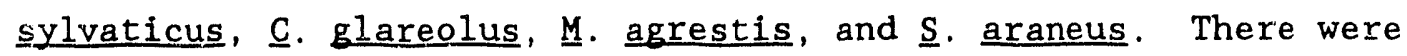
apparent species differences in accumulation which the authors related to the diet of each species. Average whole-body concentration was lowest in $\underline{M}$. agrestis $(0.6 \mathrm{ug} / \mathrm{g})$ and lower than in its diet of cover vegetation $(4 \mathrm{ug} / \mathrm{g})$. Average whole-body concentration was highest in 
T. ble 2. Concentrations of cadmium in tissues of small mammals trapped at reference sites. ${ }^{a}$

\begin{tabular}{|c|c|c|c|}
\hline \multirow[b]{2}{*}{ Species } & \multicolumn{3}{|c|}{ cadmium concentrations (ug/g dry weight) } \\
\hline & Whole body & Liver & Kidney \\
\hline Apodemus sylvaticus & 0.3 & $0.5-0.9$ & $1.7-2.2$ \\
\hline Blarina brevicauda & $0.9-1.2$ & & \\
\hline Clethrionomys glare'ilus & 0.2 & & \\
\hline Microtus agrestis & $0.1-0.9$ & $0.3-1.1$ & $0.3-5.0$ \\
\hline Microtus pennsylvanicus & $<0.4$ & $0.0-1.5$ & $0.0-5.6$ \\
\hline Peromyscus 1eucopus & & 0.4 & 0.6 \\
\hline Peromyscus maniculatus & $<0.4-1.4$ & & \\
\hline Rattus norvegicus & & 0.2 & 0.6 \\
\hline Sorex araneus & $1.2-4.0$ & $2.9-25.4$ & $4.1-25.7$ \\
\hline Sorex ciriereus & 0.7 & & \\
\hline Spermophilus variegatus & & $2-27$ & \\
\hline Talpa europea & & 30 & 59 \\
\hline
\end{tabular}

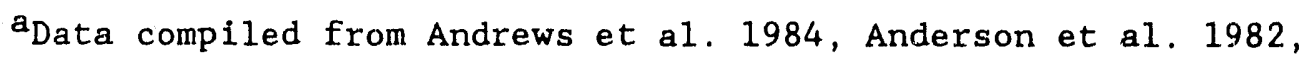
Anthony and Kozlowski 1982, Beardsley et al. 1978, Hunter and Johnson 1978, Juhnson et al. 1978, Ma 1987, Roberts and Johnson 1978, Schlesinger and Potter 1974, Sharma and Shupe 1977, and Smith and Rongstad 1982.

S. araneus $(40 \mathrm{ug} / \mathrm{g})$ and higher than in its diet of invertebrates (1.9 ug/g).

At a refinery site which included a copper-cadmium alloy plant, cadmium concentrations in tissues of $\underline{A}$. sylvaticus, $\underline{\mathbf{M}}$. agrestis, and $\underline{\mathbf{s}}$. araneus decreased with distance away from the plant (Hunter and Johnson 1982). The same pattern was true for surface soil; unwashed litter, grass, and cover vegetation; and invertebrates. Concentrations in unwashed litter and vegetation were always less thá: that of the surface soil. Concentration factors in invertebrates, compared to their estimated diets, ranged from 1.1 to 5.4. Carnivorous invertebrates contained higher concentrations than herbivorous invertebrates. 
The three species of small mammals collected at the coppercadmium alloy plant have distinct dietary patterns (Hunter and Johnson 1982). Examination of stomach contents showed that Sorex araneus ate primarily invertebrates at the top of the invertebrate food web. Microtus agrestis ate primarily green stems and leaves of grasses and A. sylviticus ate seeds and fruit. The latter two foodstuffs contained lower concentrations of cadmium than the grasses. Total-body concen-

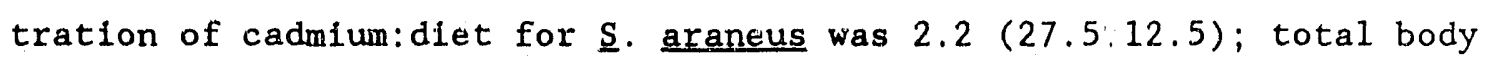
concentrations for the other two species $(<1 \mathrm{ug} / \mathrm{g}$ for $\underline{A}$. sylvaticus and $1.7 \mathrm{ug} / \mathrm{g}$ for $M$ agrestis) were less than diet concentrations.

The same pattern was true at the lead-zinc mine complex although tissue concentrations were higher in $\underline{A}$. sylvaticus than in $\underline{M}$. agrestis (Roberts and Johnson 1978). Suspension of mine wastes by wind at the derelict sites may have been less important than continuous emissions at the copper-cadmium alloy plant for deposition on grasses, thus resulting in the higher tissue concentrations for $\underline{A}$. sylvaticus than for $\underline{M}$. agrestis at the lead-zinc mine.

At a site where municipal effluent was used to irrigate the land, little accumulation of cadmium took place (Anthony and Kozlowski 1982). Concentrations were significantly higher than reference values for only kidney tissue of $\underline{\mathrm{P}}$. leucopus $(0.7 \mathrm{ug} / \mathrm{g}$ compared to $0.2 \mathrm{ug} / \mathrm{g})$; concentrations in liver and kidney tissue of $\underline{M}$. pennsylvanicus from the reference site were higher than those from the contaminated site. The effluent sludge mixture contained $5 \mathrm{ug} / \mathrm{g}$ cadmium.

Over a wide range of exposures, cadmium has a strong affinity for soft body tissues, particularly the kidney and liver (Hammond and 
Beliles 1980). At low doses the concentration in the kidney is approximately ten times that in the liver. At high exposures the liver concentration may exceed that in the kidneys. In addition to wholebody concentrations, only the kidney and liver concentrations clearly differentiated between the reference and contaminated sites in these studies. For most species and sites, kidney was the primary target organ; the tissue concentration pattern was kidney $>$ liver $>$ muscle $>$ heart $>$ bone $>$ brain. However, for $\underline{S}$. araneus the primary target tissue was the liver. Concentrations of cadmium in liver of $\underline{S}$. araneus in these studies averaged $236 \mathrm{ug} / \mathrm{g}$ at the contaminated site compared to a reference value of 2.9 (Andrews et al. 1984) and $280 \mathrm{ug} / \mathrm{g}$ compared to a reference value of 25 (Hunter and Johnson 1982).

The relationship between concentrations of cadmium in soil and concentrations in soft tissues of small mammals can be seen most clearly in $\underline{A}$. sylvaticus, the species for which most data were available (Table 3 ). Highest cadmium concentrations were measured in kidney tissue and ranged from approximately $2 \mathrm{ug} / \mathrm{g}$ at reference sites where soil concentrations ranged from 1 to $2 \mathrm{ug} / \mathrm{g}$ to nearly $40 \mathrm{ug} / \mathrm{g}$ at the most contaminated site where the soll concentration was $92 \mathrm{ug} / \mathrm{g}$. The tissue:soil relationship was of a lesser magnitude for liver tissue and wizs not clear for whole-body residues. Fewer data were available for other species, but the same relationship held true.

There may be an age-dependent accumulation of cadmium. However, only one study investigated this relationship. Schlesinger and Potter (1974) showed a relationship between body weight and cadmium accumulation for one species, B. brevicauda, but not for $\underline{\text { P. maniculatus. }}$ 
Table 3. Relationship between concentrations of cadmium in soil and tissues of Apodemus sylvaticus. ${ }^{a}$

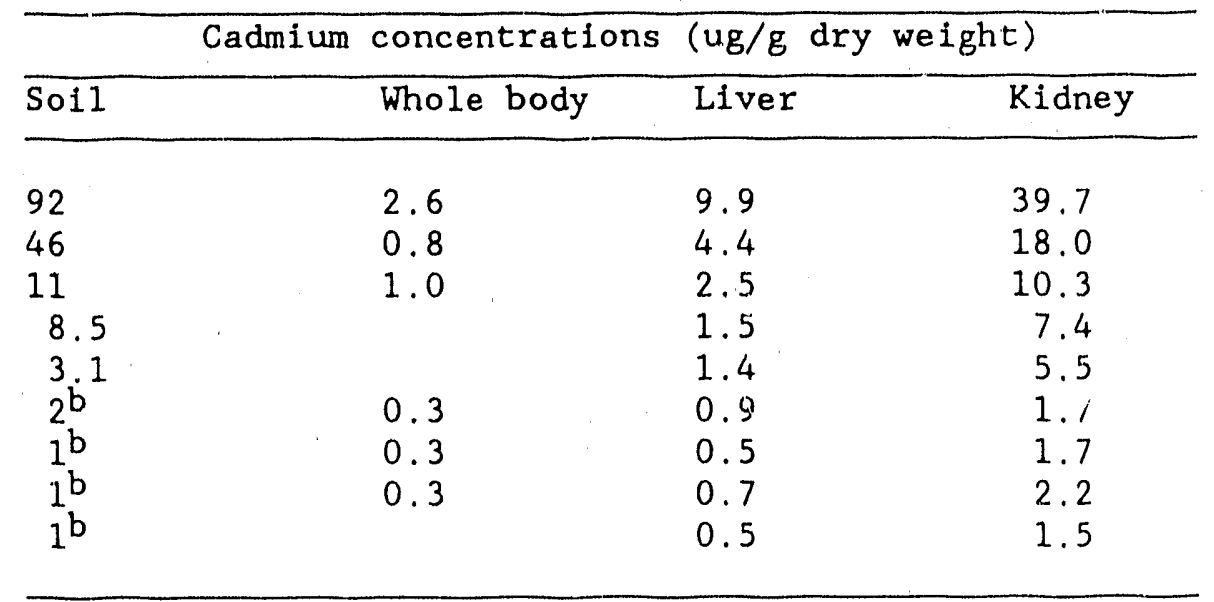

a Data compiled from Hunter and Johnson 1982, Johnson et al. 1978, and Roberts and Johnson 1978.

\footnotetext{
$b_{\text {Reference sites }}$
}

Chromium

Chromium is present in the earth's crust at a concentration of $200 \mathrm{ug} / \mathrm{g}$. Trivalent chromium is an essential element in animals. Absorption by the body is low, about 18 (Hammond and Beliles 1980). Uptake of chromium by small mammals was investigated at two sites where sewage effluent was applied to land, but no relationship between soil contamination and tissue uptake could be made (Beardsley et al. 1978, Anthony and Kozlowski 1982). Beardsley et al. (1978) compared concentrations in several tissues of $\underline{M}$. agrestis from laboratory stock and reference and sewage-contaminated areas. For some tissues, concentrations were highest in the field-collected reference animals (liver, $1.1 \mathrm{ug} / \mathrm{g} ; \mathrm{kidney}, 0.5 \mathrm{ug} / \mathrm{g}$; concentrations were similar in other tissues). At the other waste-water site, concentrations in the liver and kidney of $\underline{P}$. leucopus from the 
contaminated site were the same as concentrations in animals from the reference site, whereas concentrations in $\mathbb{M}$. pennsylvanicus collected at the reference site were higher than in those from the treated site. The treated site had received 5.0 to $7.5 \mathrm{~cm} /$ week of effluent, containing $121 \mathrm{ug} / \mathrm{g}$ chromium, for 14 years (Anthony and Kozlowski 1982). The amounts of chromium in soil, invertebrates, and vegetation were not given. Although these two studies were negative for chromium uptake, they provide too few data to draw any definitive conclusions concerning uptake of chromium.

Cobalt

Cobalt is present in the earth's crust at a concentration of 23 ug/g. It is an essential element in mammalian systems as a constituent of Vitamin $B_{12}$ (Hammond and Beliles 1980). One study (Anthony and Kozlowski 1982) also addressed the uptake of cobalt by small mammals at the site where sewage effluent was applied to field and forest areas. The mixture contained $57 \mathrm{ppb}$ cobalt and had been applied for 14 years. Microtus pennsylvanicus and $\underline{\mathrm{P}}$. leucopus captured at reference sites contained similar concentrations of cobalt: <1 ug/g in liver tissue and 1-2 ug/g in kidney tissue. There were no significant differences between concentrations of cobalt in liver and kidney tissues of mice and voles from the reference and sprayed areas.

Copper

Copper, present in the earth's crust at a concentration of 45 $\mathrm{ug} / \mathrm{g}$, is an essential element for hemogiobin synthesis and oxidative 
enzymes. The liver is involved in copper homeostasis. With increasing dietary levels of copper, the liver, kidney, bone marrow, and hair become important storage organs (Hammond and Beliles 1980). At reference sites copper concentrations in several tissues of eight species appeared to be remarkedly similar (Table 4). With the exception of the insectivores, $\underline{S}$. araneus and $I$. europea, which were slightly higher, concentrations ranged from 9 to $19 \mathrm{ug} / \mathrm{g}$ of tissue. Greatest variation was in kidney tissue, ranging from 11 to $19 \mathrm{ug} / \mathrm{g}$. Whole-body concentrations averaged $12 \mathrm{ug} / \mathrm{g}$. A study by Anthony and Kozlowski (1982) is not included in Table 4 because reference values for the kidney and liver were greatly elevated compared to the other studies. Standard deviations of the mean were high in this study. Analyses in all studies were by atomic absorption spectroscopy.

Environmental contamination by copper results from mining and refinery operations and from application of sewage to land. Nine species captured at such sites showed varying accumulation of copper. Copper concentrations were significantly elevated in liver tissue of A. sylvaticus $(23.7 \mathrm{ug} / \mathrm{g})$, kidney and hair of $\underline{M}$. dgrestis $(22.6$ and $24.2 \mathrm{ug} / \mathrm{g}$, respectively), and liver and hair of $\underline{\mathrm{s}}$. araneus (56.1 and $77.8 \mathrm{ug} / \mathrm{g}$, respectively) collected at a copper refinery where surface soll values averaged $2,480 \mathrm{ug} / \mathrm{g}$ (Hunter and Johnson 1982). The degree of contamination was highest in the shrew and lowest in the mouse. Hy, ghest concentrations were found in the liver of two of the species.

Whole-body concentrations were significantly higher in $\underline{P}$. $\underline{\text { manicu }}$.tus and $\underline{M}$. pennsylvanicus trapped at a zinc-copper mine than 
Table 4. Concentrations of copper in tissues of sma11 mammals trapped at reference sites. ${ }^{a}$

\begin{tabular}{|c|c|c|c|}
\hline \multirow[b]{2}{*}{ Species } & \multicolumn{3}{|c|}{ Copper concentrations (ug/g dry weight) } \\
\hline & Whole body & Liver & Kidney \\
\hline Apodemus sylvaticus & & 12.9 & 13.5 \\
\hline Blarina brevicauda & $9-10.6$ & & \\
\hline Microtus agrestis & & $13.4-16$ & $10.8-19$ \\
\hline Microtus pennsylvanicus & 11.9 & 17.3 & 15.6 \\
\hline Peromyscus maniculatus & $10-13.4$ & & \\
\hline Sorex araneus & & 31.1 & 22.8 \\
\hline Sorex cinereus & 12.8 & & \\
\hline Talpa europea & & 23 & 25 \\
\hline
\end{tabular}

${ }^{a_{\text {Data }}}$ compiled from Anderson et a1. 1982, Anthony and Kozlowski 1982, Beardsley et al. 1978, Hunter and Johnson 1978, Ma 1987, Schlesinger and Potter 1974, and Smith and Rongstad 1982.

at a reference site, with concentrations higher in $P$. maniculatus than in $M$. pennsylvanicus (Smith and Rongstad 1982). Relative to reference values, uptake was greater in $\underline{P}$. maniculatus than in $\underline{M}$. pennsylvanicus or $\underline{B}$. brevicauda. In another study, there were no differences in liver and kidney concentrations between reference and effluent-sludge disposal sites for $\underline{M}$. pennsylvanicus and $\underline{P}$. leucopus (Anthony and Kozlowski 1982). Concentrations were generally higher in tissues of animals from the reference sites.

Since copper is well regulated by the body, it is not a candidate to be monitored by small mammals except at sites that are suspected to be extremely highly contaminated as shown in the study by Hunter and Johnson (1982). At this site both $\underline{S}$. araneus and $\underline{M}$. agrestis showed elevated concentrations when uptake by several different tissues was considered. Relative to reference concentrations, concentrations in both grass and invertebrates were high, averaging 153 and $375 \mathrm{ug} / \mathrm{g}$ in 
different types of vegetation (the food of $M$. agrestig) and 310,343 , and $568 \mathrm{ug} / \mathrm{g}$ in different types of invertebrates (the food of $\underline{\mathrm{S}}$. araneus).

Lead

Although the average concentration of lead in the earth's crust is $15 \mathrm{ug} / \mathrm{g}$, concentrations at reference sites in monitoring sites were higher, 78 and $96 \mathrm{ug} / \mathrm{g}$. Lead is a nonessential element in mammalian systems. Most lead enters the body through ingestion and ninety percent of the total body burden is found in the bone. Higher than average body concentrations are also found in the kidney and liver. Since the excretion rate is low, the lead burden increases with age. In addition to body and tissue burdens, evidence of exposure to high concentrations of lead can be seen by the production of intranuclear inclusion bodies in the proximal tubule cells of the kidney, inhibition of delta-amino levulinic acid dehydratase (ALAD), and renal edema (Goyer et al. 1970, Hammond and Beliles 1980).

In all studies, lead in tissue and whole-body samples of smal1 mammals was analyzed by atomic absorption spectrometry following acid digestion (wet oxidation). Tissues were processed wet, freeze-dried, or dried to a constant weight at $100^{\circ} \mathrm{C}$. Concentrations were reported on a dry weight basis.

Concentrations of lead in tissues of several species of small mammals collected at reference sites varied considerably (Table 5). Concentrations in bone, kidney, liver, and whole body ranged from 5 to $25,<1$ to 13,1 to 12 , and 2 to $18 \mathrm{ug} / \mathrm{g}$, respectively. The wide range of concentrations for reference areas makes it difficult to estimate a 
Table 5. Tissue and whole body concentrations of lead in small mammals from rufererice sites, ${ }^{a}$

\begin{tabular}{|c|c|c|c|c|}
\hline \multirow[b]{2}{*}{ Species } & \multicolumn{4}{|c|}{ Lead (ug/g dry weight) } \\
\hline & Bone & Kidney & Liver & Whole Body \\
\hline Apodemus sylvaticus & $1.2-25$ & $<0.4-1.3$ & $3.5-9$ & $3-4$ \\
\hline Blarina brevicauda & & & & $3-17$ \\
\hline Clethrionomys glareolus & & 5 & $8-12$ & $5-8$ \\
\hline Microtus agrestis & 6 & $6-9$ & 4 & $5-9$ \\
\hline Microtus ochrogaster & & & & 3 \\
\hline Microtus pennsylvanicus & & $4-13$ & $1-2$ & $2 \cdot 18$ \\
\hline Mus musculus & 9.3 & 3.4 & 1.9 & 4.6 \\
\hline Peromyscus Leucopus & & 13 & 3 & $2.6-6.4$ \\
\hline Peromyscus maniculatus & $5-6$ & $2-3$ & 1.1 & $3-9$ \\
\hline Rattus norvegicus & $10-14$ & $4-6$ & $1-3$ & \\
\hline Reithrodontomys megalotis & & & & 3 \\
\hline Sorex araneus & & & & 3 \\
\hline Sorex cinereus & & & & 3 \\
\hline Talpa europea & 22 & 9 & & \\
\hline
\end{tabular}

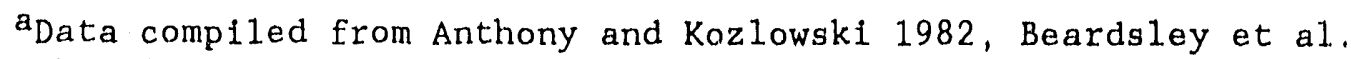
1978, Chmiel and Harrison 1981, Clark 1979, Elfving et a1. 1978, Gardner et al. 1978, Getz et al. 1977, Goldsmith and Scanlon 1977, Haschek et a1. 1979, Jefferles and French 1972, Johnson et al. 1.982, Ma 1987, Mierau and Favara 1975, Mour et al. 1975, Quarles et al. 1977, Roberts and Johnson 1978, Roberts et al. 1978, Scanlon 1977, Smith and Rongstad 1982, Welch and Dick 1975, and Williamson ani Evans 1972.

baseline concentration for any species or any tissue. The differences may be due to numerous biological and environmental factors including the natural variability of the lead content of the soll and vegetation, diet of the species, season of the year, and age and sex of the animals.

A number of studies have shown the effect of automobile exhaust on lead concentrations in small animals living various distances from highways of different traffic densities. In general, the concentrations of lead in soll, vegetation, invertebrates, and selected tissues of mammals correlate with the traffic density of the highway (Jefferies 
and French 1972, Welch and Dick 1975, Goldsmith and Scanlon 1977, Getz et al. 1977, Scanlon 1979). A compllation of the data on traffic density and lead concentrations in several tissues of $P$. maniculatus, the species for which most data were avallable, shows this relationship (Table 6). Although the relationship holds true for all of the tissues, it is most dramatic for bone. Concentrations ranged from approximately $5 \mathrm{ug} / \mathrm{g}$ in bone at untravelled reference sices to $106 \mathrm{ug} / \mathrm{g}$ at a major highway. Concentrations of lead in soll were not provided for these sites. In addition to the relationship with traffic density, there was also a gradient effect of tissue lead concentrations with distance from the highway (Williamson and Evans 1972, Quarles et al. 1974). Al1 species had highest lead concentrations at sites adjacent to heavy-use highways.

In other studies the elevated concentrations of lead in tissues reflected elevated concentrations in soll, vegetation, and invertebrates. The greatest environmental contamination with lead occurred at abandoned lead-zinc mines in Great Britain (Johnson et a1. 1978, Roberts and Johnson 1978, Roberts et al. 1978). At one such site, lead concentrations in soll averaged $14,010 \mathrm{ug} / \mathrm{g}$; the highest whole-body concentration of lead was found in $\underline{M}$. agrestis $(140.4 \mathrm{ug} / \mathrm{g}$ ) (Roberts and Johnson 1978). The highest reported mean tissue concentration of lead was in bone of $\underline{A}$. sylvaticus at an abandoned smelter waste heap, $672 \mathrm{ug} / \mathrm{g}$ (Johnson et al. 1978). There were general increases in all tissues except muscle at these contaminated sites compared to tissues of animals from respective reference sites. There was also accumulation in vegetation and invertebrates compared to respective reference 
Table 6. Relationship between traffic density and tissue concentrations of lead in Peromyscus maniculatus. a

\begin{tabular}{llccc}
\hline \multirow{2}{*}{ Vehicles/day } & \multicolumn{4}{c}{ Tissue concentrations (ug/g dry welght) } \\
\cline { 3 - 5 } & Whole body & Liver & Kidney & Bone \\
\hline 38,000 & & 4.6 & 23 & 106 \\
19,800 & & 3.3 & 8.5 & 52 \\
19,600 & 5.5 & 3.5 & 7.9 & 24.6 \\
18,500 & & 1.3 & 3.9 & 27 \\
9,500 & & 0.8 & 1.7 & 8.6 \\
4,200 & 3.7 & 0.7 & 2.6 & 5.1 \\
1,360 & 1.7 & 9 & 8 \\
340 & 2.4 & 1.8 & 3 & 6.4 \\
Reference & & 1.1 & 3.3 & 4.8 \\
Reference & 2.8 & 1.1 & 1.8 & 5.7 \\
& & & & \\
\hline
\end{tabular}

aData compiled from Getz et al. 1977, Mierau and Favara 1975, and Welch and Dick 1975.

sites, with greater uptake in vegetation $(249 / 29 \mathrm{ug} / \mathrm{g})$ than in invertebrates $(82 / 22 \mathrm{ug} / \mathrm{g})$.

The most data on tissue concentrations in relation to soil concentrations were available for A. sylvaticus (Table 7). Concentrations at reference sites for this species were: whole body, 3 to 4 $\mathrm{ug} / \mathrm{g}$; 1iver, 3.5 to $9 \mathrm{ug} / \mathrm{g}$; kidney, <1 to $13 \mathrm{ug} / \mathrm{g}$; and bone, 11.5 to 25 $\mathrm{ug} / \mathrm{g}$. Concentrations in several tissues of this species collected at contaminated sites were elevated, but did not reflect differences in environmental lead levels. Bone, followed by kidney, were the target tissues for lead.

At sewage-sludge treated areas, concentrations in soil were not reported, but are presumably lower than in the above studies. Significant differences betwean reference and contaminated sites were seen for some tissues, but, in general, uptake was low (Beardsley et al. 1978, Anthony and Kozlowski 1982, Anderson et al. 1982). There were 
Table 7. Relationship between lead concentrations in soll and tissues of Apodemus sylvaticus. a

\begin{tabular}{ccccc}
\hline \multicolumn{5}{c}{ Lead concentrations } \\
\hline Solig/g dry weight) & \\
\hline & Whole body & Liver & Kidney & Bone \\
\hline 14,010 & 43.1 & 13.0 & 39.2 & 189 \\
8,430 & 26.7 & 11.7 & 46.6 & 352 \\
4,030 & & 12.1 & 65.2 & 672 \\
150 & 12 & & \\
120 & & 9.5 & 6.5 & 11.5 \\
$96^{\mathrm{b}}$ & 2.9 & 7.9 & 12.7 & 21.1 \\
$78^{\mathrm{b}}$ & 3.8 & 5.4 & 9.4 & \\
Reference & & 9.0 & 5.0 & 25 \\
Reference & 3.5 & 6.1 & & \\
Reference & & 3.5 & $<0.4$ & \\
\hline
\end{tabular}

${ }^{a}$ Data compiled from Chriel and Harrison 1981, Johnson et al. 1978, Roberts and Johnson 1978, Roberts et al. 1978, and Williamson and Evans 1972.

$b_{\text {Reference sites }}$

significant differences in selected tissues of rats ( $R$. norvegicus) collected in urban and rural areas (Mouw et al. 1975, Way and Schrocler 1982).

At an abandoned orchard that had been treated with lead-arsenate for insect control, lead wals still present in soll several years later $(218 \mathrm{ug} / \mathrm{g})$, and accumulated in several tissues of voles and mice (Elfving et al. 1978, Haschek et a1. 1979). The authors related uptake to the degree of subsurface feeding and movement of the three species, with concentrations in pine voles $>$ meadow voles $>$ white-footed mice, but there were too few data to draw firm cunclusions.

Although bone, kidney, and liver, in that order, are the primary target tissues for lead accumulation, most studies measured whole body concentrations. Because inhalation may be an important route of uptake 
adjacent to heavily traveled roads, one study (Getz et al. 1977) also measured concentrations in the lung tissue. Concentrations were higher In lung rissue for $\underline{B}$. brevicauda and $B$. megalotis from the contaminated area, but statistical analyses were not performed on this tissue. Much higher concentrations were found in bone and kidney tissue.

In addition to tissue residues, exposure to lead may be monitored by observing changes in cellular structures and enzyme levels. The most sensitive index of lead polsoning is the presence of intranuclear inclusion bodies in the epithelial cells of the proximal tubules of the kidney. These bodies are composed of protein and lead and may be formed following a single dose of lead (Hammond and Bellies 1980). In experimental studies, renal lead levels as low as $13 \mathrm{ug} / \mathrm{g}$ have been associated with cellular alterations (Goyer et a1. 1970).

Intranuclear inclusion bodies were found in the proximal tubule cells of $20 / 23$ rats caught in urban areas and in none of the rats caught in rural areas by Mouw et al. (1975). Lead concentrations in the kidney were $30.2 \mathrm{ug} / \mathrm{g}$ in urban rats and $1.5 \mathrm{ug} / \mathrm{g}$ in rural rats. Urban rats also exhibited excess kidney weight and had reduced ALAD in the kidney and red blood cells.

Intranucliar inclusion bodies were also found in $M$. agrestis trapped on spoil heaps of two abandoned lead-zinc mines (Roberts et al. 1978). No nuclear alterations were present in the tissues of animals from matched control sites. Whole body lead concentrations averaged 128.4 and $135.9 \mathrm{ug} / \mathrm{g}$ at the two mine sites; concentrations in renal tissue were not given, and no consistent relationship between whole body and kidney concentrations could be made from the reported values. 
Renal edema was observed in $\underline{M}$. agrestis and $\underline{A}$. sylvaticus from sites where kidney and bone concentrations were very high $(46.6 \mathrm{ug} / \mathrm{g}$ and 352 $\mathrm{ug} / \mathrm{g}$ for kidney and bone, respectively) in $\mathrm{A}$. sylvaticus; concentrations for $M$. agrestis were not given.

Meadow voles and pine voles ( $\underline{M}$. pennsylvanicus and $\underline{M}$. pinetorum) from lead-arsenate treated orchards had lesions in the epithelial cells of the proximal convoluted cells of the kidney (Elfving et al. 1978, Haschek et al. 1979). The cells were enlarged, degenerating, and contained enlarged nuclei with intranuclear inclusion bodies. There was also arrested development in the long bones. Lead concentrations in meadow voles trapped in the orchard ranged from 14 to $41 \mathrm{ug} / \mathrm{g}$ in kidney and from 73 to $303 \mathrm{ug} / \mathrm{g}$ in bone. Two pine viles contained 27 and $30 \mathrm{ug} / \mathrm{g}$ in kidney and 306 and $401 \mathrm{ug} / \mathrm{g}$ in bone.

Lead poisoning ras not observed in populations of deer mice (․ maniculatus) living adjacent to a major highway in Colorado (Mierau and Favara 1975). Kidney and bone concentrations in this population averaged 8.5 and $52.1 \mathrm{ug} / \mathrm{g}$, respectively. Lead poisoning was not investigated in other roadside populations. Data from all of the above studies agree with the laboratory study of Goyer et al. (1970) which showed that the lowest concentration of lead in the kidney that produces renal changes is $13 \mathrm{ug} / \mathrm{g}$.

Manganese

Beardsley et al. (1978) investigated the concentrations of manganese (an essential element) in several tissues of $\underline{M}$. agrestis trapped at a sewage-sludge treated area, an unpolluted grassland, and a laboratory stock of this species. Concentrations in vegetation at the 
reference and polluted sites were 38 and $183 \mathrm{ug} / \mathrm{g}$, respectively. Differences in median concentrations of manganese in several tissues of the vole were small and erratic and no conclusions could be drawn.

Mercury

There is a scarcity of data on mercury exposure of small mammals at contaminated sites. Mercury was analyzed by atomic absorption spectroscopy and values were reported as total mercury; only one study made a distinction between inorganic and organic mercury. In three studies, residues of mercury in whole bodies and tissues of $\underline{A}$. sylvaticus, $\underline{B}$. brevicauda, and $\underline{C}$. glareolus from reference areas were $\leq 0.1$ ug/g. Concentrations in sámples of surface soil and grass (ug/g dry weight) and earthworms (ug/g wet weight) at a reference site were 0.11 , 0.10, and 0.04, respectively (Bull et al. 1977). Hammond and Bellies (1980) cite $0.5 \mathrm{ug} / \mathrm{g}$ as an average value for the earth's crust. In the above study (Bull et al. 1977), concentrations within $0.5 \mathrm{~km}$ of a chlor-alkali plant were $3.8,4.0$, and 1.3 for these three compartments, respectively, showing no uptake over soll concentrations by vegetation or invertebrates. Conversely, small mammals living within $0.5 \mathrm{~km}$ of the plant accumulated mercury in their tissues, with slightly higher concentrations in the mouse, $\underline{A}$. sylvaticus, than in the vole, $\underline{C}$. glareolus. The highest concentrations were in the muscle of $A$. sylvaticus $(3.43 \mathrm{ug} / \mathrm{g})$ and in the kidney of $\underline{\mathrm{C}}$. glareolus $(1.24 \mathrm{ug} / \mathrm{g})$. For the two species caught in this study, tissue concentrations were statistically higher in hair, kidney, and liver of $\underline{A}$. sylvaticus and in brain and hair of $\underline{\underline{C}}$. glareolus from the contaminated site. Although methyl mercury is not emitt ad by the plant, some of the total mercury 
$(<108)$ in the tissues of the animals was in the form of methyl mercury. Of several species of small mammals trapped at an active zinc-copper mine, only a composite sample of two $\underline{B}$. brevicauda had concentrations higher than two reference animals (Smith and Rongstad 1982). Concentrations in soil, vegetation, and invertebrates were not given.

Concentrations of total mercury in small mammals trapped in fields sown with wheat treated with an organomercury fungicide were higher following sowing, but declined with time (Jefferies and French 1973, Jefferies and French 1976, Westlake et al. 1980). Residues were detected up to several months after planting. Apodemus sylvaticus, which inhabited both the open field and the surrounding pastures and woodland, fed immediately on the seed as indicated by increased residues during the two weeks after sowing. Clethrionomys glareolus was caught almost exclusively on the grass borders of the fields and $\underline{M}$. agrestis was caught only in short grass. These habitat patterns are reflected in the low tissue concentrations of these two species. Since A. Sylvaticus was the only species that lived on or ventured into the treated fields, a comparative evaluation of accumulation could not be made.

Nickel

The accumulation of this nonessential element was investigated at an active zinc-copper mine (Smith and Rongstad 1982) and at field and forest sites sprayed with sewage-sludge effluent containing $75 \mathrm{ug} / \mathrm{g}$ nickel (Anthony and Kozlowski 1982). Soil concentrations at neither site were given. The average concentration in soil at uncontaminated sites is $80 \mathrm{ug} / \mathrm{g}$. Whole-body concentrations of animals collected at 
uncontaminated areas ranged from $2.2 \mathrm{ug} / \mathrm{g}$ for the jumping mouse ( $\mathcal{Z}$. hudsonius) to $6.2 \mathrm{ug} / \mathrm{g}$ for the deer mouse ( $\underline{P}$. maniculatus). Concentrations in the liver and kidney of $\underline{P}$. leucopus and $\underline{M}$. pennsylvanicus were similar (2.0-15 ug/g). Nickel did not accumulate in mice, shrews, or voles at either site; in all cases, reference concentrations were higher than concentrations at the contaminated sites.

Zinc

Zinc, a ubiquitous element in the environment, is an essential trace element. It is present in the earth's crust at a concentration of $65 \mathrm{ug} / \mathrm{g}$. In mammalian systems, zinc is involved in enzyme functions, protein synthesis, and carbohydrate metabolism (Hammond and Beliles 1980).

The average concentrations in whole-body samples of nine species of small mammals captured at reference sites ranged from 96 to $143 \mathrm{ug} / \mathrm{g}$ and averaged $108 \mathrm{ug} / \mathrm{g}$ (Table 8). Averages in liver ranged from 120 to 199, and averages in kidney ranged from 104 to $192 \mathrm{ug} / \mathrm{g}$. There were too few data for some species and too much variation among studies to make specific statements about concentrations in tissues of a particular species.

Dry-weight body burdens for four species were elevated one- to two-fold at an abancioned lead-zinc mine relative to reference concentrations (Johnson et al. 1978, Roberts and Johnson 1978). But body burdens for $\underline{M}$ agrestis $(191.6 \mathrm{ug} / \mathrm{g})$, A. sylvaticus $(107.3 \mathrm{ug} / \mathrm{g}$ ), S. araneus $(141.1 \mathrm{ug} / \mathrm{g})$, and $\underline{C}$. glareolus $(123.4 \mathrm{ug} / \mathrm{g}$ ) were lower than soil $(21,000 \mathrm{ug} / \mathrm{g})$, vegetation $(340 \mathrm{ug} / \mathrm{g})$ and invertebrate (220-270 $u g / g$ ) concentrations and thus were less than their estimated diets. 
Table 8. Concentrations of zinc in tissues of small mammals trapped at reference sites. ${ }^{a}$

\begin{tabular}{llll}
\hline & \multicolumn{3}{l}{ Zinc concentrations (ug/g dry weight) } \\
\cline { 2 - 4 } Species & Whole body & Liver & Kidney \\
\hline Apodemus sylvaticus & $96-112$ & 133 & 158 \\
Blarina brevicauda & 96 & & \\
Clethrionomys glareolus & $103-143$ & 120 & 104 \\
Microtus agrestis & 121 & $138-199$ & $115-192$ \\
Microtus pennsylvanicus & 107 & 161 & 140 \\
Peromyscus leucopus & & & \\
Peromyscus maniculatus & 106 & & \\
Sorex araneus & $96-111$ & & \\
Zapus hudsonius & 107 & &
\end{tabular}

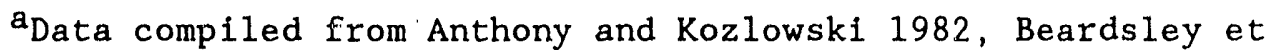
al. 1978, Johnson et al. 1978, Roberts and Johnson 1978, and Smith and Rongstad 1982.

The increase in body burden was significant in only $\underline{M}$. agrestis (reference $121.2 \mathrm{ug} / \mathrm{g}$ ), but the increase was only $50 \mathrm{z}$ in contrast to a 17-fold increase in the vegetation on which it feeds.

Radionuclides

Biomonitoring may be a critical technique for determining the presence of leaks at radioactive waste sites, but literature on this subject is scarce (Table 9). Kaye and Dunaway (1962) measured bioaccumulation of radionuclides in $\underline{\mathrm{P}}$. 1eucopus and $\underline{\mathrm{S}}$. hispidus at several contaminated sites at ORNL. They did not include a reference site in this preliminary study. They found that body burdens were higher than those expected from radioactive fallout, but too few animals of either species were caught to draw conclusions about sentinel species. Tissues of muskrats (. Ondatra zibethica), rabbits (Sylvilagus 


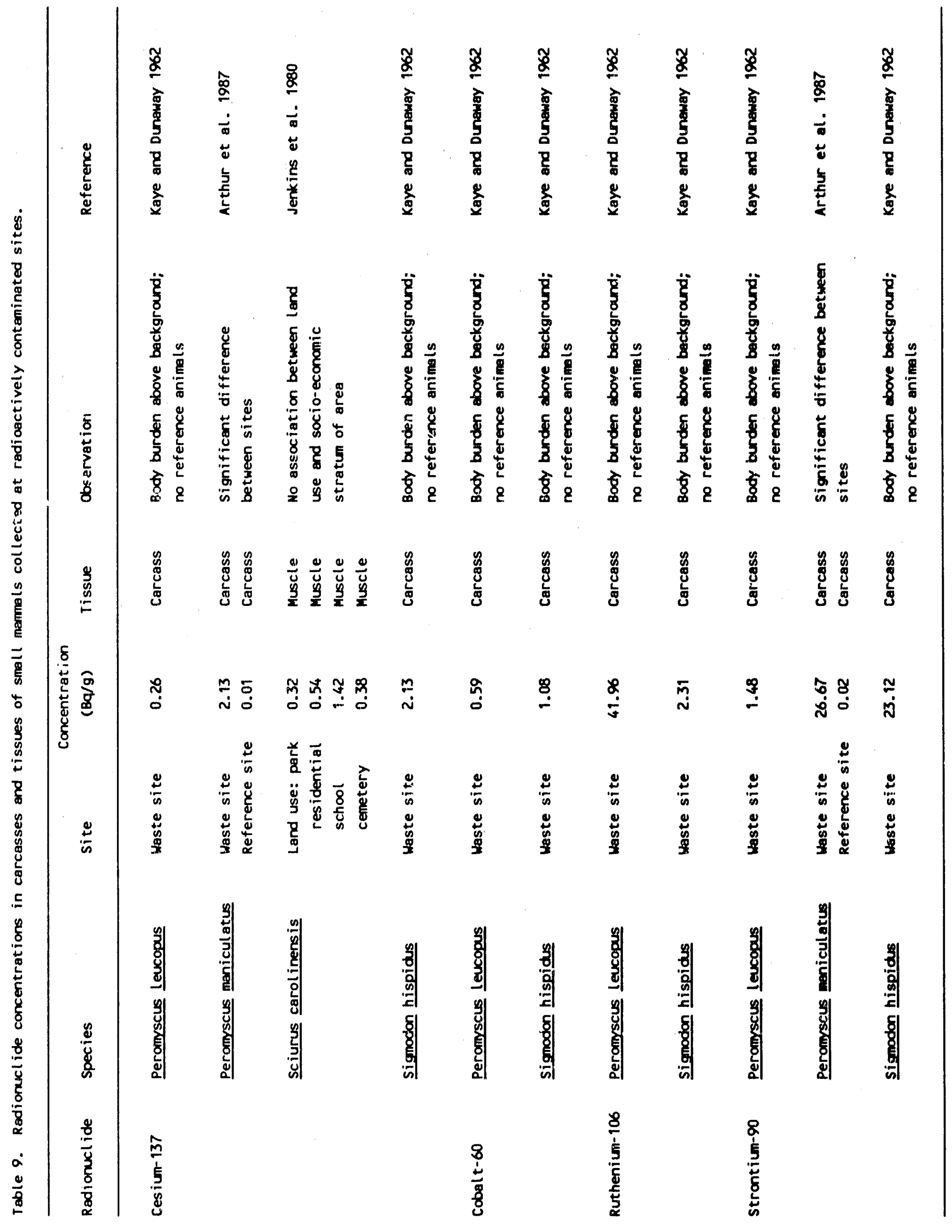


floridanus), and a cotton mouse ( $\underline{\text { S }}$ hispidus) were analyzed for different radionuclides. Strontium-90 concentrations were highest in bone, whereas cesium-137 was present in all soft tissues. They did find large variations in bioaccumulation among individuals of a single species.

Arthur et al. (1987) measured radionuclide concentrations in tissues of deer mice ( $\underline{P}$. maniculatus), the most abundant species at the Subsurface Disposal Area of the Idaho National Engineering Laboratory. Deer mice were contaminated with radionuclides in areas where the surface soil was contaminated and in areas where the waste was covered with $0.6 \mathrm{~m}$ soil. Exposure at the latter site was presumably due to burrowing activity since the two dominant plant species on this site, crested wheatgrass and Russian thistle, were not contaminated. Concentrations of strontium-90 and cesium-137 in carcasses were significantly different from concentrations at the reference site. Concentrations of americium-241, plutonium-238, and plutonium-239+240 in carcasses were all less than $1 \mathrm{~Bq} / \mathrm{g}$. No other tissue, except lung, was analyzed for radionuclides. Other species were present at the site, but were not analyzed. Small mammals were also trapped at sites contaminated with actinide elements (Garten et al. 1987, Halford 1987), but tissue concentrations were generally below $1 \mathrm{~Bq} / \mathrm{g}$ of tissue.

\section{Organic Contaminants}

Many organic chemicals are not susceptible to either biotic or abiotic degradation and consequently are persistent in the environment. These compounds tend to be lipophilic and may also accumulate through 
food chains. Thus, potential hazards to wildlife exist due to the toxicity of these chemicals.

In addition to residue analyses, a variety of biochemical and cytogenetic assays can be applied to determine the presence and effects of persistent organic compounds. Where complex mixtures are present, such as at hazardous waste sites, a number of nonchemical-specific assays, originally developed for laboratory studies, have been applled.

Many of the present chemicals of concern, such as insecticides, were developed for their toxicity and persistence in the environment. Unfortunately, many insecticides are not selective, and nontarget species may be affected. Chlorinated hydrocarbon insecticides that are persistent in the environment and may be potentially harmful to wildife include DDT and its metabolites, dieldrin, Kepone, mirex, and the hexachlorocyclohexanes (Menzer and Nelson 1980).

Organochlorine insecticides are being replaced, in many instances, by organophosphate and carbamate pesticides. Most of the latter compounds are cholinesterase inhibitors and the problems of persistence and chronic toxicity seen with the organochlorines have been replaced with the problem of acute toxicity and less selectively. Because the transient nature of organophosphate insecticides as well as the ir higher potency make the measurement of residues difficult, biochemical assays such as cholinesterase inhibition have been used to measure effects on wildlife populations. Other biochemical assays such as mixed function oxidase induction have been applied to monitor exposures of several species, including fish (Jimenez et al. 1987), but have not yielded repeatable results when applied to natural populations of 
terrestrial animals (Rattner and Hoffman 1987). Blochemical markers such as the formation of contaminant adducts with deoxyribonucleic acids (DNA) or hemoglobin have been investigated in the laboratory (Calleman 1984, Shugart 1985) and are potentially useful for fleld studies. Cytogenetic assays have been applied at sites where mixtures of unidentified chemicals are present. Residue analyses and biochemical assays applied to small mammalis exposed to organic contaminants and hazardous wastes are summarized in Table 10. Most analyses were performed on a wet weight basis.

DDT and metabolites.

DDT is an environmentally stable organochlorine pesticide. Residues of DD'T and DDD and DDE, its major metabolites, are ubiquitous. The residues are highly lipophilic and concentrate through food chains (Murphy 1980). Although the Environmental Protection Agency has restricted the use of DDT, residues persist in the environment. Accumulation in small mammals is of concern because small mammals such as Microtus spp. serve as prey for raptors and DDE-induced egg-she11 thinning has been linked to reproductive failure in these birds (Kendal1 1982).

Environmental persistence is evidenced by the presence of measurable residues in mice, voles, and shrews nine years after single applications to forests in Maine at a rate of $0.89 \mathrm{~kg} / \mathrm{ha}$ ( $1 \mathrm{lb} / \mathrm{bcre}$ ) (Dimond and Sherburne 1969). Pooled samples of shrews (ㅆ. hoy 1 , B. brevicauda, and Sorex sp.) contained an average of $15.58 \mathrm{ug} / \mathrm{g}$ wet weight of DDT residues during the year of application and $1.18 \mathrm{ug} / \mathrm{g}$ nine years later. Pooled samples of mice (Peromyscus sp.) and voles 


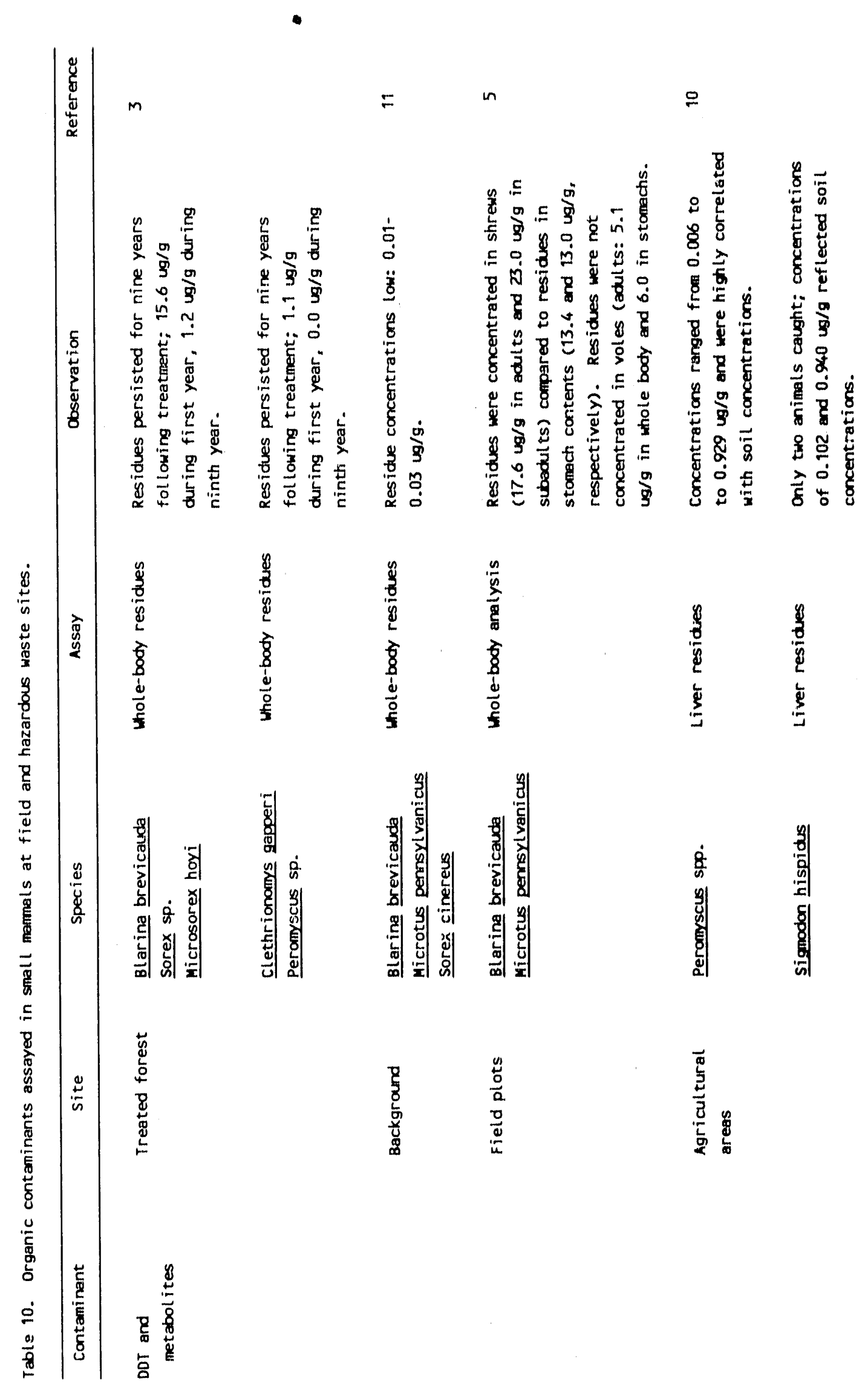




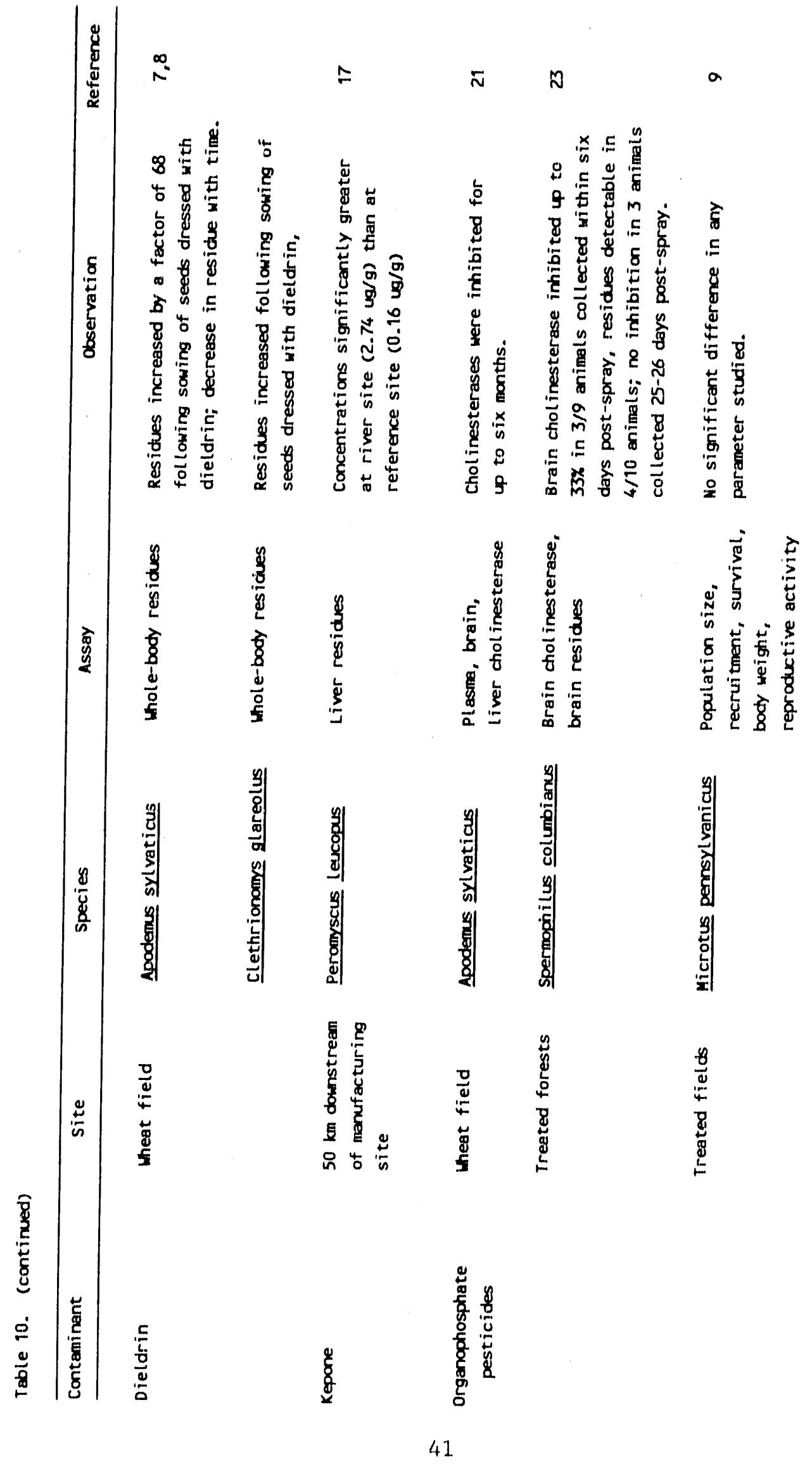




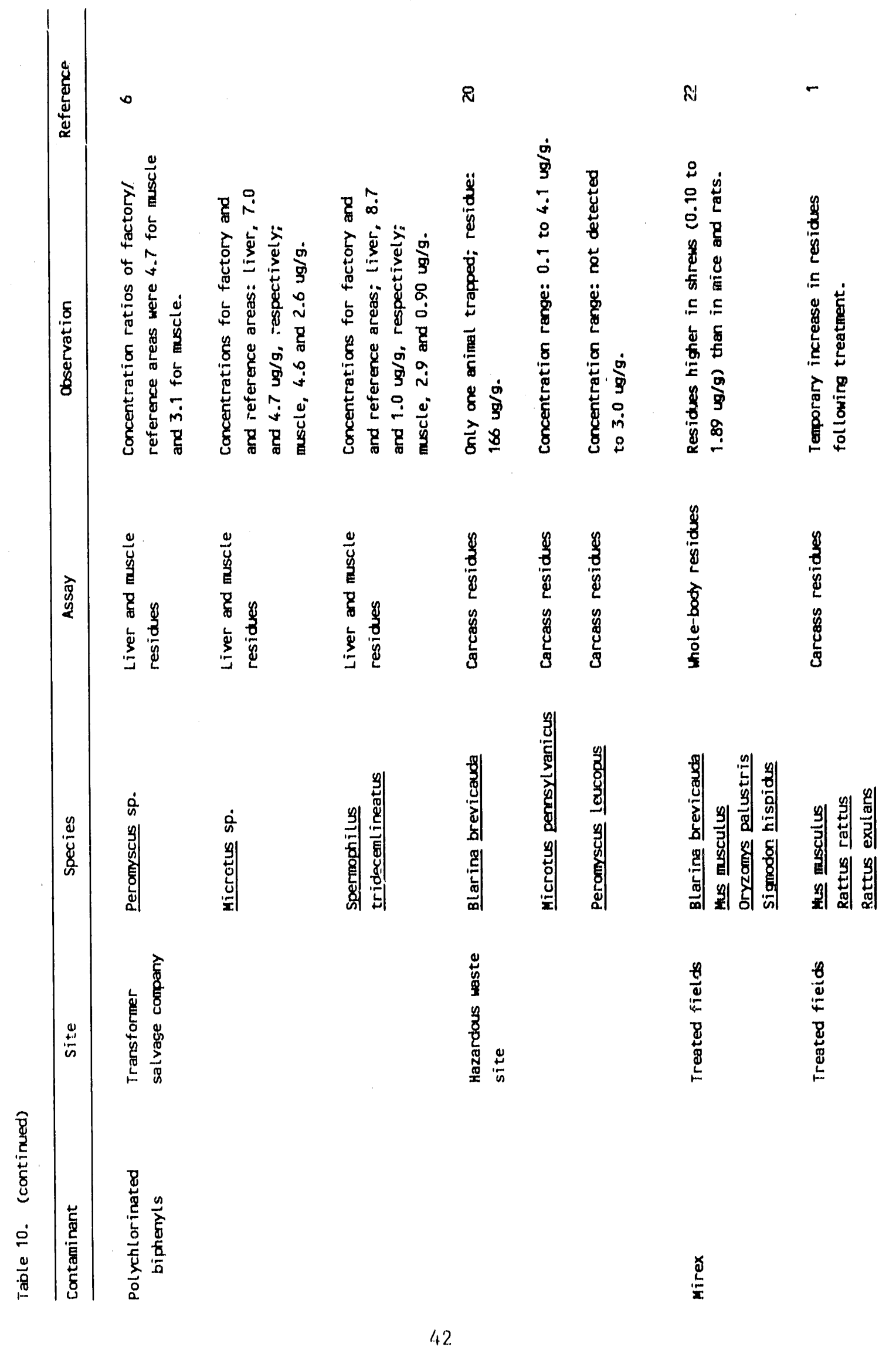




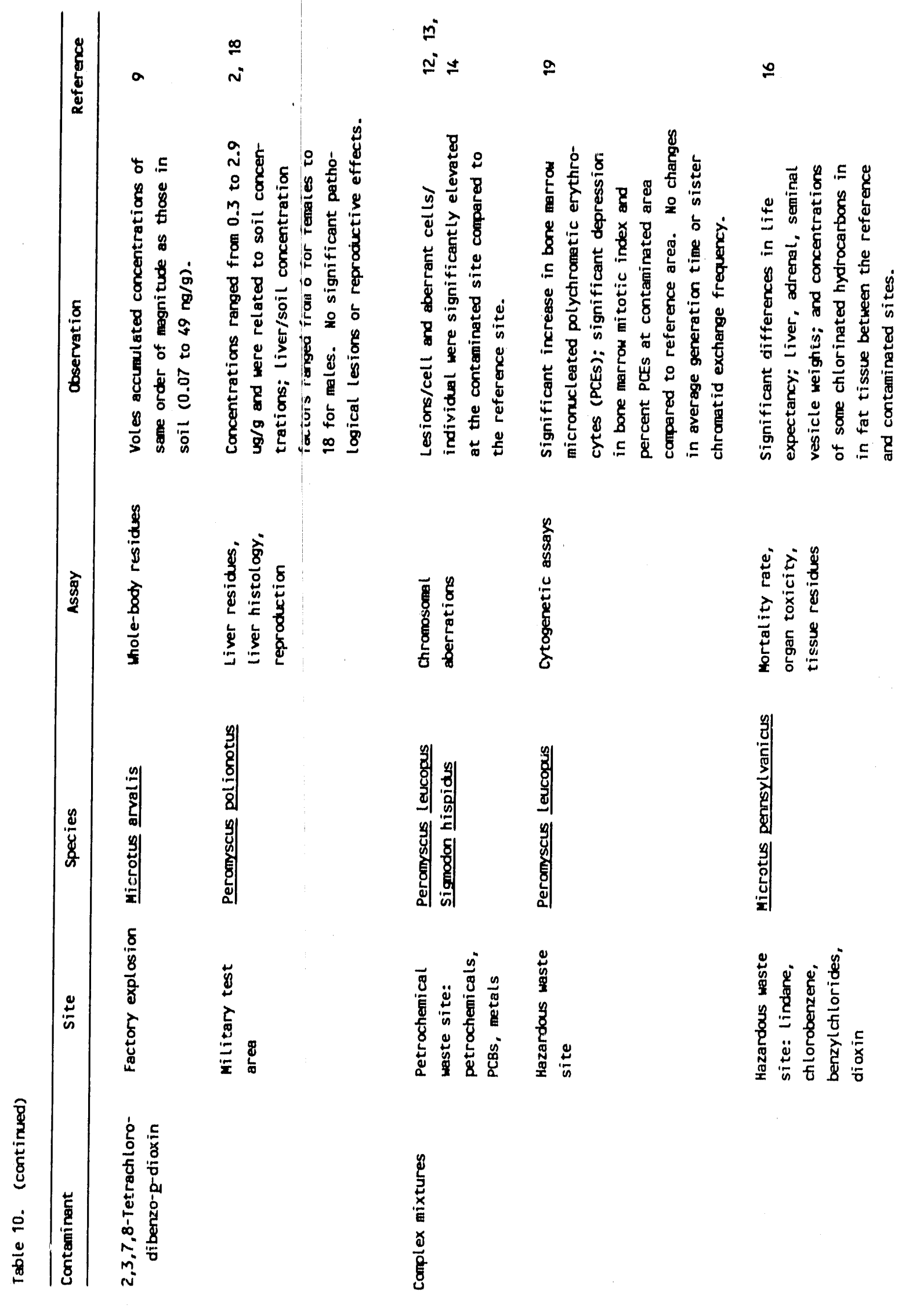




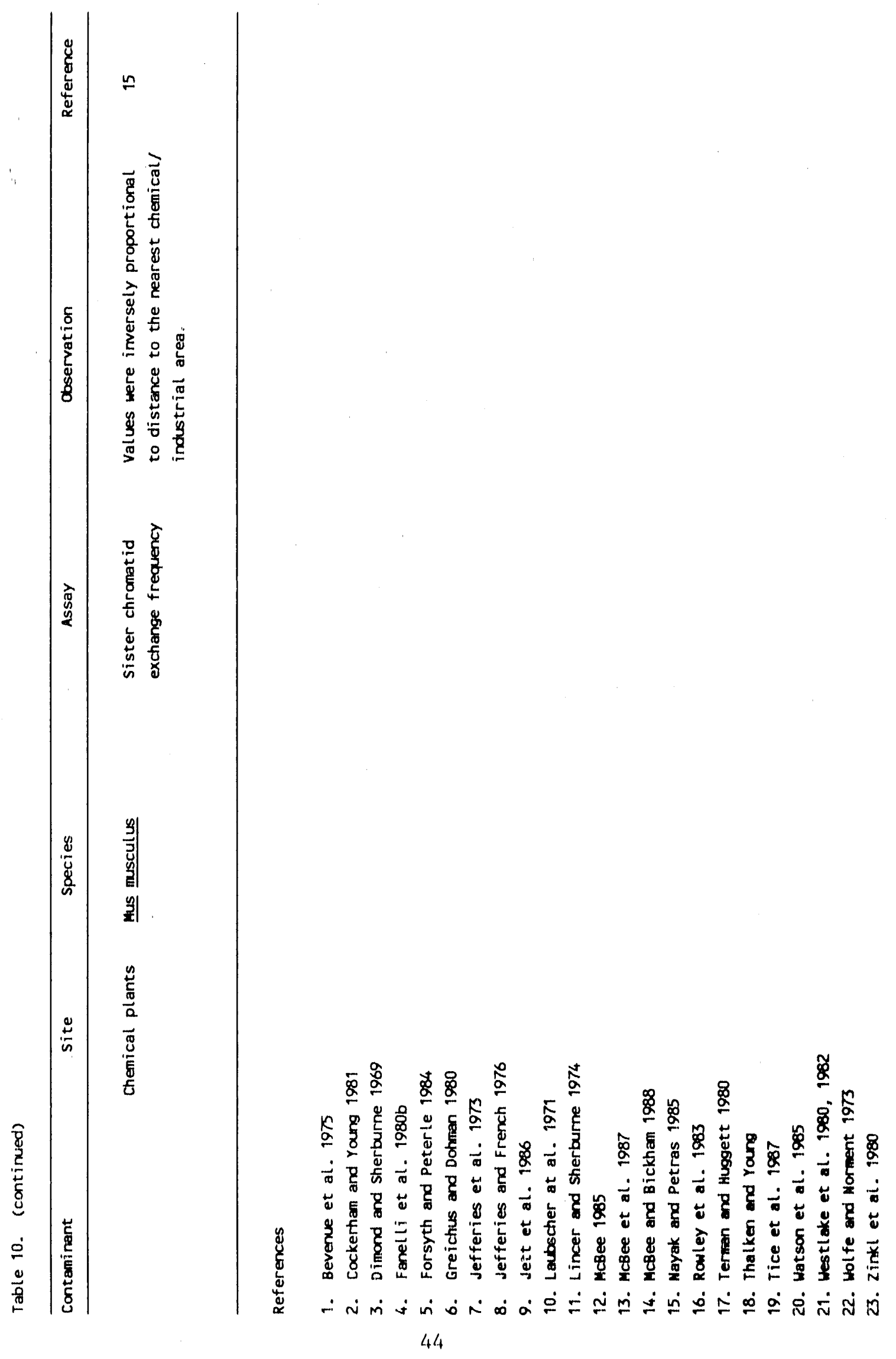


(G. gapperi) contained $1.06 \mathrm{ug} / \mathrm{g}$ during the first year and $0.04 \mathrm{ug} / \mathrm{g}$ nine years later. The two groups collected from an untreated area contained 0.30 and $0.03 \mathrm{ug} / \mathrm{g}$, respectively. DDE residues $i^{\prime \prime}$ voles (․․ pennsylvanicus) and shrews ( $\underline{B}$. bravicauda and $\underline{s}$. cinereus) in the Ithaca, New York, area were 0.01 and $0.03 \mathrm{ug} / \mathrm{g}$, respectively (Lincer. and Sherburne 1974). It was not reported when this area or nearby areas had been treated. In a third field study, total residues of DDT were detected at concentrations ranging from 0.006 to $0.929 \mathrm{ug} / \mathrm{g}$ wet weight in whole bodies of $\underline{\underline{P}}$. leucopus and were related to soil concentrations of 3.6 to $6,700 \mathrm{ug} / \mathrm{g}$ (Laubscher et al. 1971).

Following treatment of field plots with ${ }^{36} \mathrm{Cl}$-DDT, concentrations of total DDT residues were greater in shrews (B. brevicauda, $17.6 \mathrm{ug} / \mathrm{g}$ wet weight) than in voles ( $\underline{M}$. pennsylvanicus, $5.1 \mathrm{ug} / \mathrm{g}$ ) (Forsyth and Peterle 1984). Whole body residues were higher in juveniles than in adults and increased with increasing body fat concent. Whole body residues were greater than residues in stomach contents of $\underline{B}$. breyicauda, thus showing bioaccumulation; this was not true for $\underline{M}$. pennsylvanicus.

Dieldrin

As part of an investigation of the food chain transfer of chlorinated organic compounds to carnivorous birds in Britain, a study of the dieldrin residues of their small mammal prey was made (Jefferies et al. 1973, Jefferies and French 1976). Until 1974, both an organomercury fungicide and the insecticide dieldrin were commonly used to treat cereal seeds before sowing. Dieldrin residues were measured in small mammals before and up to two months after sowing. Results showed that 
the field mouse (A. sylvaticus), which inhabited the open fields and the grassy areas surrounding the fields, fed immediately on the seeds. This resulted in elevated concentrations one day after sowing. The bank vole (‥ glareolus) was restricted in its habitat to the field edges, resulting in lower, but erratic concentrations of residues compared to the field mouse.

\section{Kepone}

The pesticide, Kepone, was released to the James River, Virginia, and the Chesapeake Bay through careless manufacturing practices at a small chemical plant in Hopewe11, Virginia (Menzer and Nelson 1980). Monitoring with two populations of the white-footed mouse ( $\underline{P}$. leucopus), one located on an island in the James River, $50 \mathrm{~km}$ downstream of the plant and the other located $4.8 \mathrm{~km}$ inland of the river, established that Kepone has moved into the terrestrial environment (Terman and Huggett 1980). Kepone was found in all of the mice on the island. Significantly lower concentrations were found in 708 of mice trapped at a reference site $4.8 \mathrm{~km}$ inland. No detectable amount was present in a laboratory-reared individual of this species. Concentrations in other compartments were not measured, and thus comparisons with other species could not be made.

Mirex

Mirex has been used for fire ant control in the southeastern United States. Mirex is persistent in the environment; residues in soil, water, and vegetation were found to be constant over a period of 300 days (Val Valin 1968, Murphy 1980). Acute toxicity to wildlife is 
low. Mirex residues were monitored in wildlife in Mississippi for one year following an aerial application (Wolfe and Norment 1973). Wholebody residues in several species were related to food habits, with the shrew (ㅁ. brevicauda) having the highest concentrations (up to 1.89 $\mathrm{ug} / \mathrm{g}$ wet weight). Herbivores generally had lower concentrations than omnivores.

Mirex residues were also monitored in several small mammals (M. musculus, R. rattus, and $\underline{\mathrm{R}}$. exulans) before and after aerial application to pineapple fields in Hawail (Bevenue et al. 1975). Prior to application, residues for all species were $<0.3 \mathrm{ug} / \mathrm{g}$ wet weight. Within three months of application, residues ranged up to $9.4 \mathrm{ug} / \mathrm{g}$ in the Polynesian rat ( $\underline{R}$. exulans) and then declined to background values by the tentr month. Thus, mirex appears to lend itself to only shortterm biomonitoring.

Organophosphate Pesticides

The use of biochemical assays to complement residue analyses is an important technique for the investigation of the effects of newly developed pesticides on wildlife. Westlake et al. $(1980,1982)$ used the field mouse (A. sylvaticus) as an indicator species to investigate the effect of the insecticides chlorfenvinphos and carbophenothion on wildlife. Following sowing of seed dressed with these chemicals, the pattern and persistence of esterase inhibition in several tissues reflected the persistence of these insecticides in the field. Likewise, Zink: et al. (1980) found that brain cholinesterase was depressed in birds and two species of squirrels after an aerial application of acephate. At this level of arplication, the inhibition of cholines- 
terase in birds was close to the toxic leve1, but the depression in squirrels was much lower.

Polychlorinated Biphenyls (PCBs)

PCBs are exceptionally environmentally persistent chlorinated hydrocarbons that have been used as insulating materials in electrical capacitors and transformers and in plasticizers, fire retardants, hydraulic and lubricating fluids, and heat exchangers. The large amounts manufactured, their widescale use, and chemical stability have led to worldwide contamination. They have contaminated the environment through industrial discharges, movement from disposal sites, and use of oil wastes containing PCBs as a dust control measure on parking lots and roads. PCBs are lipophilic which, in addition to their stability, leads to bioaccumulation in fat tissue (Menzer and Nelson 1980, Watson et al. 1985). In the laboratory, administration of PCBs has led to reproductive failure in $\underline{P}$. leucopus (Linzey 1987).

Small mammals have been used to monitor the movement of PCBs from two contaminated sites, one in South Dakota and one in New York. PCBs were measured in the area surrounding two electrical transformer salvage companies near Colman, South Dakota (Greichus and Dohman 1980). Concentrations were highest in soll $(<0.025$ to $46 \mathrm{ug} / \mathrm{g})$, lowest in vegetation $(0.3$ to $2.2 \mathrm{ug} / \mathrm{g})$ and earthworms $(1.96 \mathrm{ug} / \mathrm{g})$, and intermediate in smal1 mammals. Concentrations ranged from 2.07 to $17.2 \mathrm{ug} / \mathrm{g}$ in liver tissue of small mammals and 2.89 to $6.87 \mathrm{in}$ muscle. The highest concentration was in the liver of the mouse (Peromyscus sp.), but too few animals of other species were caught to make meaningful comparisons. PCBs were detectable in small mammals trapped in an area 
believed to be relatively Iree of contamination and ranged up to 4.7 $u g / g$ in liver; this value appears to be high when compared to undetect. able amounts in several animals trapped at a contaminated waste site in New York state (Watson et al. 1985). The study does indicate that PCBs are accumulating in small mammals over the concentrations found in their sources of food.

PCBs also moved from soil into the food chain at a hazardous waste site in New York state where 452 tons of liquid waste containing PCBs and other organic compounds were dumped (Watson et al. 1985). As a dust control measure, an access road to the site had been repeatedly treated with oil containing PCBs. Ranges of PCBs in several media were: soil, 5.5 to 6,300 ; vegetation, 0.3 to 2.0 ; invertebrates, 0.1 to 60; and small mammal carcasses, not detected to $166 \mathrm{ug} / \mathrm{g}$ wet weight. Except for the high value in a single shrew (166 ug/g), concentrations were variable but similar in the mouse ( $\underline{P}$. leucopus) and vole ( $\underline{M}$. pennsylvanicus). The nondetectable values in some of the animals indicate recent immigration or activity away from the area of contamination. A reference area was not investigated.

\section{2, 3, 7, 8-Tetrachlorodibenzo-p-dioxin (TCDD)}

In the past, TCDD was a contaminant of the herbicide 2,4,5trichlorophenoxyacetic acid $(2,4,5-T)$. 2,3, 7,8-Tetrachlorodibenzo-pdioxin has entered the environment through the extensive use of $2,4,5-\mathrm{T}$ in agriculture to control broad-leaf weeds and as a consequence of the explosion of a chemical plant in Sevesco, Italy in 1976. During the 1960s, TCDD was extensively used in military defoliation operations in Southeast Asia. More recently, it has been shown to be produced during 
the combustion of fossil fuels and incineration of municipal wastes. It is extremely toxic to some species, causing degenerative changes in the liver and thymus and altering serum enzyme concentrations (Menzer and Nelson 1980). In humans it has been found to cause chloracne and is a teratogen.

Following an explosion at a chemical plant in Italy, a large area around the plant was contaminated with TCDD; thousands of small animals died within a few weeks (Fane111 et al. 1980a). Four years later, measurements in the common vole ( $\underline{M}$ arvalis) and other animals showed that TCDD was still accurnulating in wildlife (Fanelli et al. 1980b). Whole-body concentrations of voles ranged from 0.07 to $49 \mathrm{ppb}$ (average $4.5 \mathrm{pph}$ ); contamination of the soil ranged from 0.01 to $12 \mathrm{ppb}$ (average $3.5 \mathrm{ppb})$. Values at reference sites were not given, but presumably should be below the level of detection.

Aerial spraying equipment for the defoliation operation in Southeast Asia was tested at Eglin Air Force Base in Florida (Thalken and Young 1981). The test area was sprayed with $73,000 \mathrm{~kg}$ of 2,4,5-T during the period 1962-1970. Although no residues of the herbicide were present eight years later, residues of TCDD were still present. Animals were abundant on the site, and tissue residues were monitored in the beach mouse ( $\underline{P}$. polionotus). There was a close relationship between soil and liver concentrations of TCDD. Bioconcentration factors (liver/soil) (wet weight) ranged from six to 18. There were no histopathological differences between liver tissues of mice from the contaminated and reference sites (Cockerham and Young 1981). 
Complex Mixtures

Biomonitoring at sites contaminated with a complex mixture of chemicals, especially when the chemicals are unidentified, is difficult. Biochemical analyses for a variety of chemicals can be timeconsuming and expensive. In addition, measuring body burdens of specific chemicals does not take into account the potential for interactions within the organism. At such sites a variety of physiological and biochemical assays can be employed. In three studies, cytogenetic or genotoxic assays were applied to field populations of small mammals at sites containing complex mixtures of waste shemicals.

Monitoring chromosomal aberrations in small mammals at a petrochemical waste disposal site was used as a natural model for the analysis of environmental. mutagenesis (McBee 1985, McBee et a1. 1987, McBee and Bickham 1988). From 1961 to 1985 the site had been used for fire-fighting training exercises. Retention ponds on the site contained a mixture of oil, grease, partially combusted hydrocarbon compounds, PCBs, hexachlorobenzene and a variety of metals. Two species of small mammals, the white-footed mouse ( $P$. leucopus) and the cotton rat ( $\underline{\text {. hispidus) }}$, were trapped in sufficiently large numbers to allow statistical analyses of differences in chromosome aberrations between the contaminated site and a reference site. Using several assays (karyology, G-band karyology, and flow cytometry), all of which detect DNA damage, differences between the populations at the contaminated and reference sites were found for both species in one or more of the assays. Peromyscus leucopus had significantly more

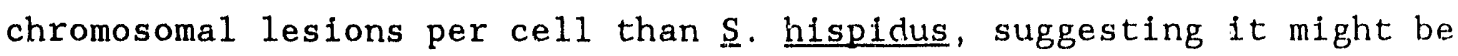


of DNA damage. Using the Ames assay, an earlier study had Indicated that the water in the waste pond was mutagenic to Salmonella typhimurIum (Brown and Donnelly 1982).

Tice et a1. (1987) examined only one species, P. leucopus, for genotoxic and cytotoxic damage at a U.S. EPA Superfund site in Camden County, New Jersey. They examined bone marrow cells for micronucleated polychromatic erythrocytes, sister chromatid exchange, average generation time, and mitotic index and peripheral blood for percent polychromatic erythrocytes. A significant increase in bone marrow micronucleated polychromatic erythrocytes was found in addition to a significant depression in both bone marrow mitotic index and percent polychromatic erythrocytes in peripheral blood at the hazardous waste site compared with a control site. There were no alterations in average generation time of celis or sister chromatid exchange frequency. They also compared the field-caught specimens with their laboratory colony of $\underline{P}$. leucopus and found a significant increase in mitotic index in the laboratory-reared stock.

Nayak and Petras (1985) also used sister chromatid exchange frequency to compare wild-caught and laboratory-reared populations of mice, $\underline{M}$. musculus. Sister chromatid exchange values were higher in wild-caught mice than in the laboratory population and the values in wild-caught mice were inversely proportional to distance between the site of capture and the nearest industrial area. Field-caught mice maintained in the laboratory for nine or more months had sister chromatid exchange values similar to those of the laboratory stock. 
Rowley et al. (1983) used field voles (M. pennsylvanicus) to assess risk of hazardous chemicals to wildlife at a waste site in Love Canal, New York. Field voles were chosen because they were the most common spectes at the site and in the surrounding area. The site contains over 6,900 tons of lindane, 2,000 tons of chlorobenzenes, 2,400 tons of benzylchlorides, and 200 tons of trichlorophenol contaminated with dioxin. A variety of assays were used as endpoints: mean life expectancy, organ toxicity, and tissue residues. The investigators found significant differences in population density; mean life expectancy; liver, adrenal, and seminal vesicle weights; and concentrations of some chlorinated hydrocarbons in fat tisue between the contaminated and reference sites.

In follow-up studies, mice and rats were exposed to the Love Canal soil or extracts of the soil under laboratory conditions. Mice exposed by direct contact with the soil had increased body and liver weights (Silkworth et al, 1984). Pregnant rats administered extracts of the soll by gavage showed effects on maternal health and fetal development (Silkworth et a1. 1986). Benzene hexachlorides, tetrachloroethanes, and TCDD were identified in the soil and extracts.

\section{Evaluation of Study Species as Monitors}

Based on the studies discussed in the previous three sections, an evaluation of the sultability of each species as a sentinel species for specific contaminants can be made (Table 11). This assessment of each species as a biomonitor is based on the extent of accumulation, significant differences between means of residues in animals from 


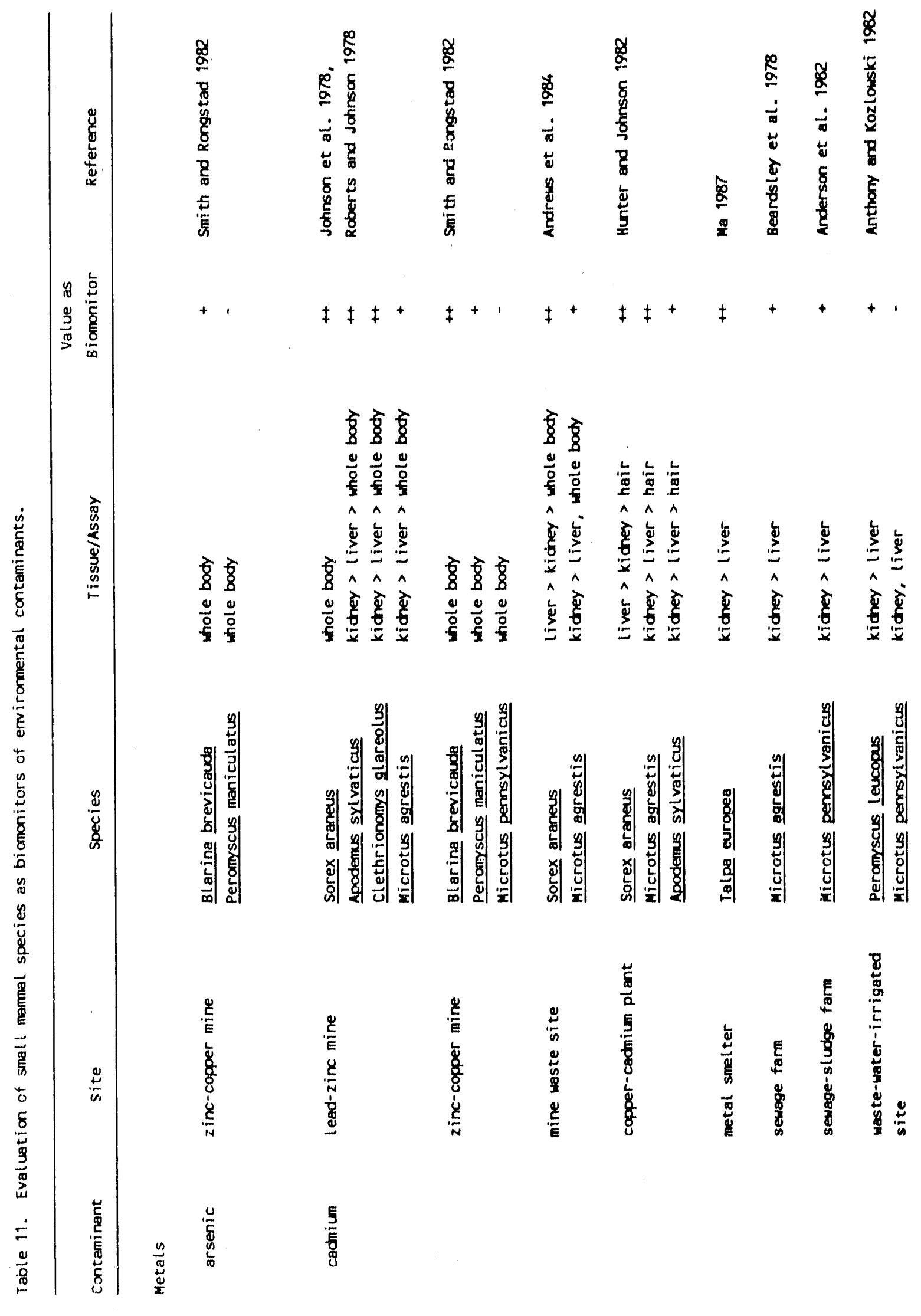




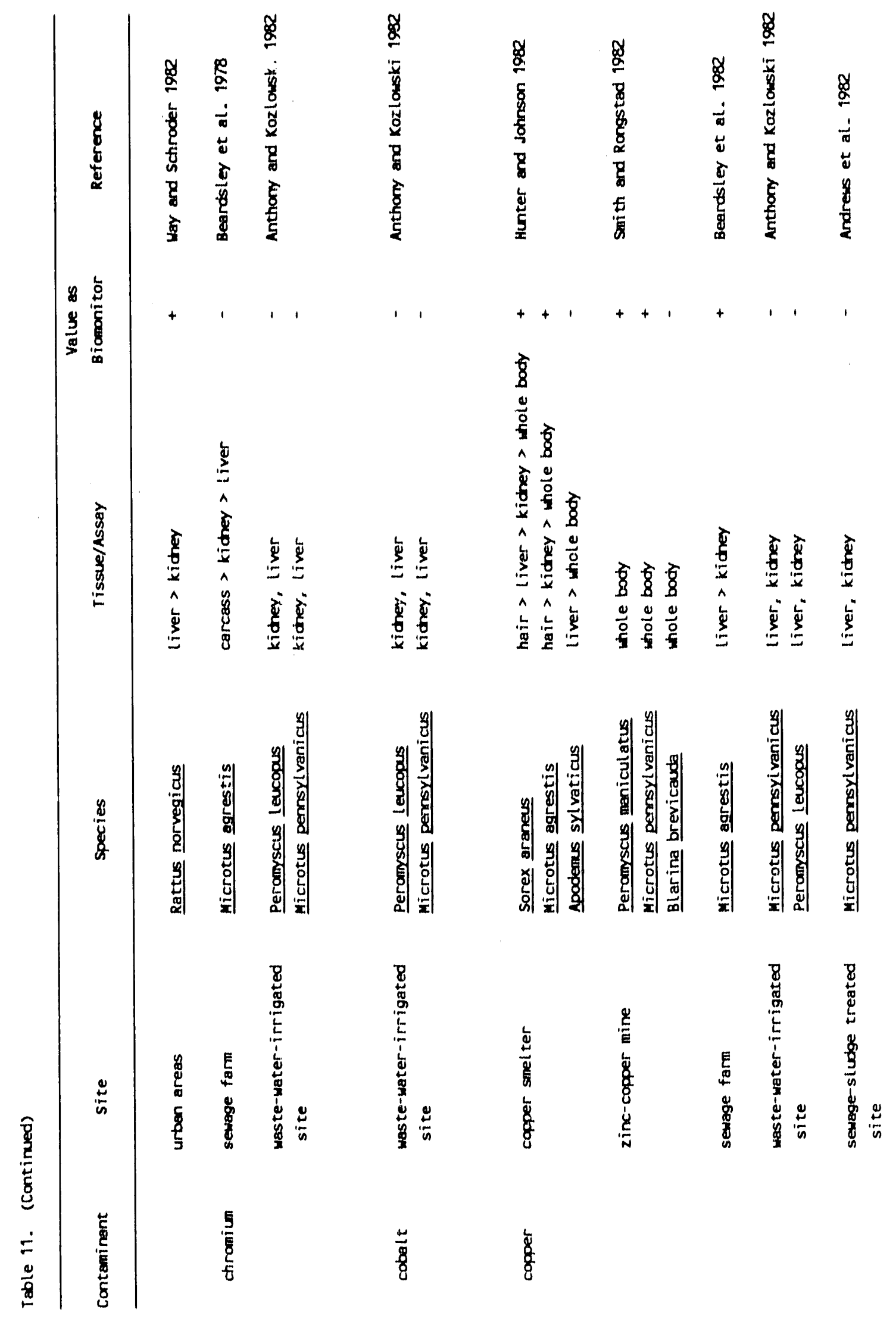




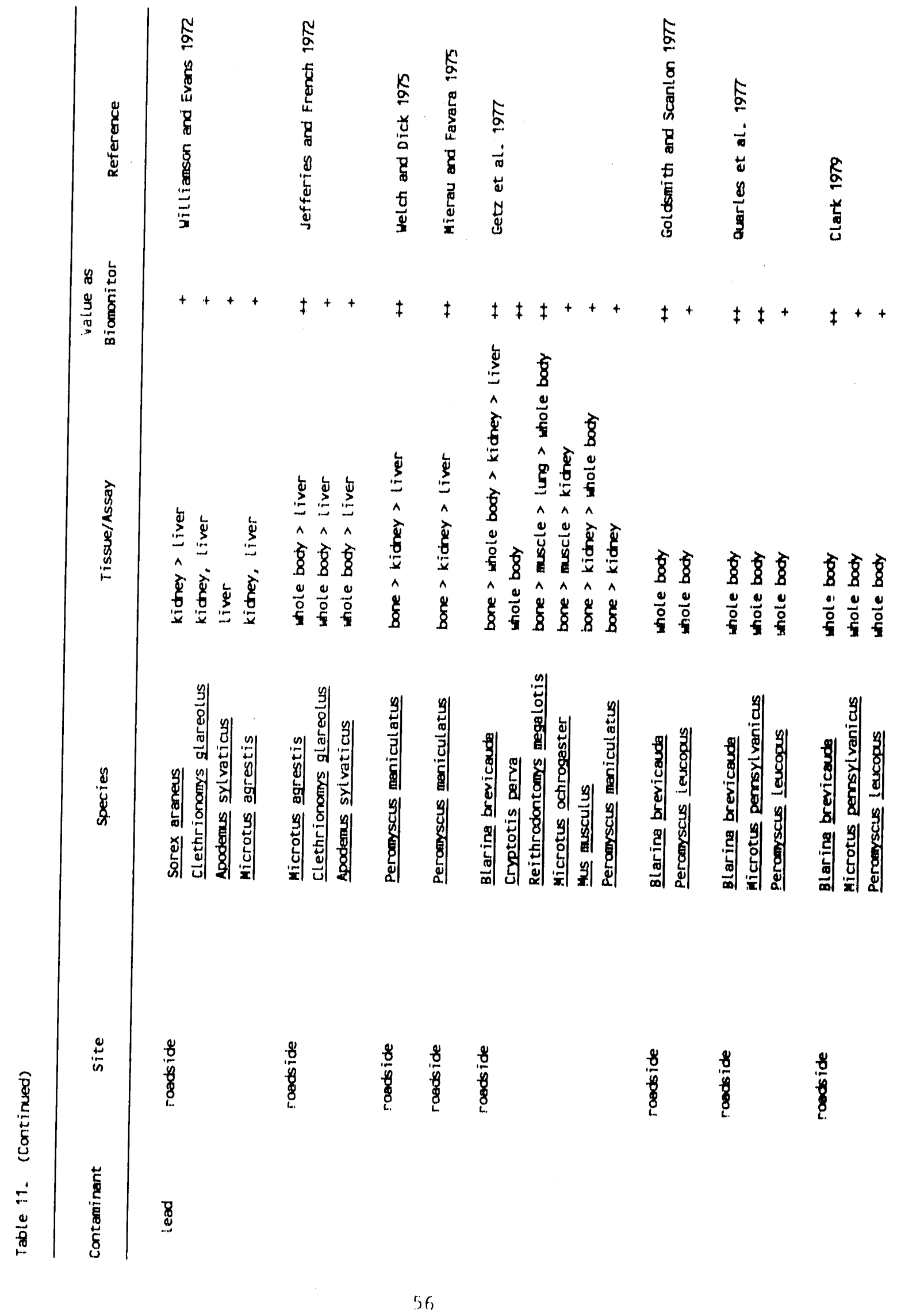




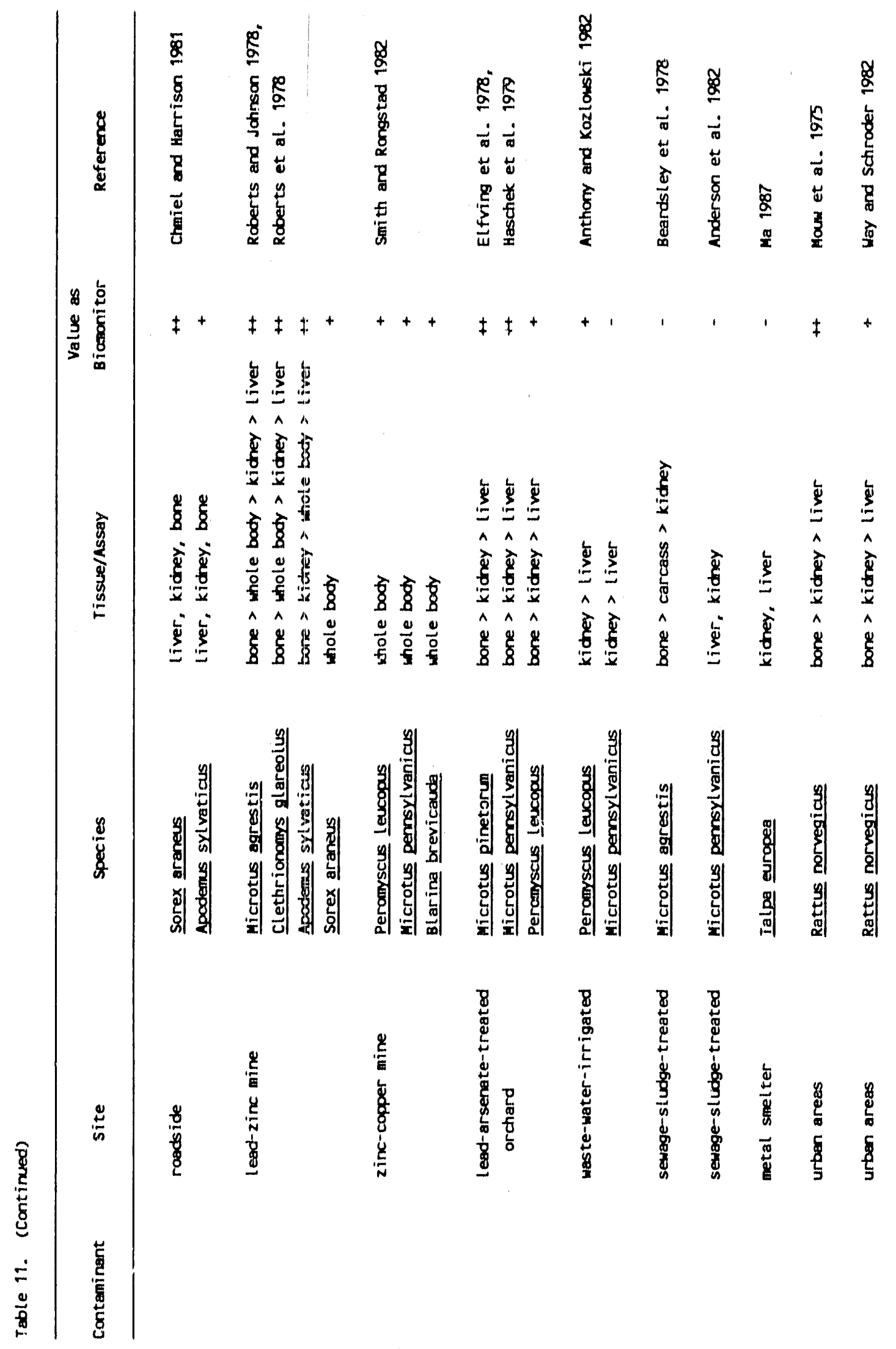




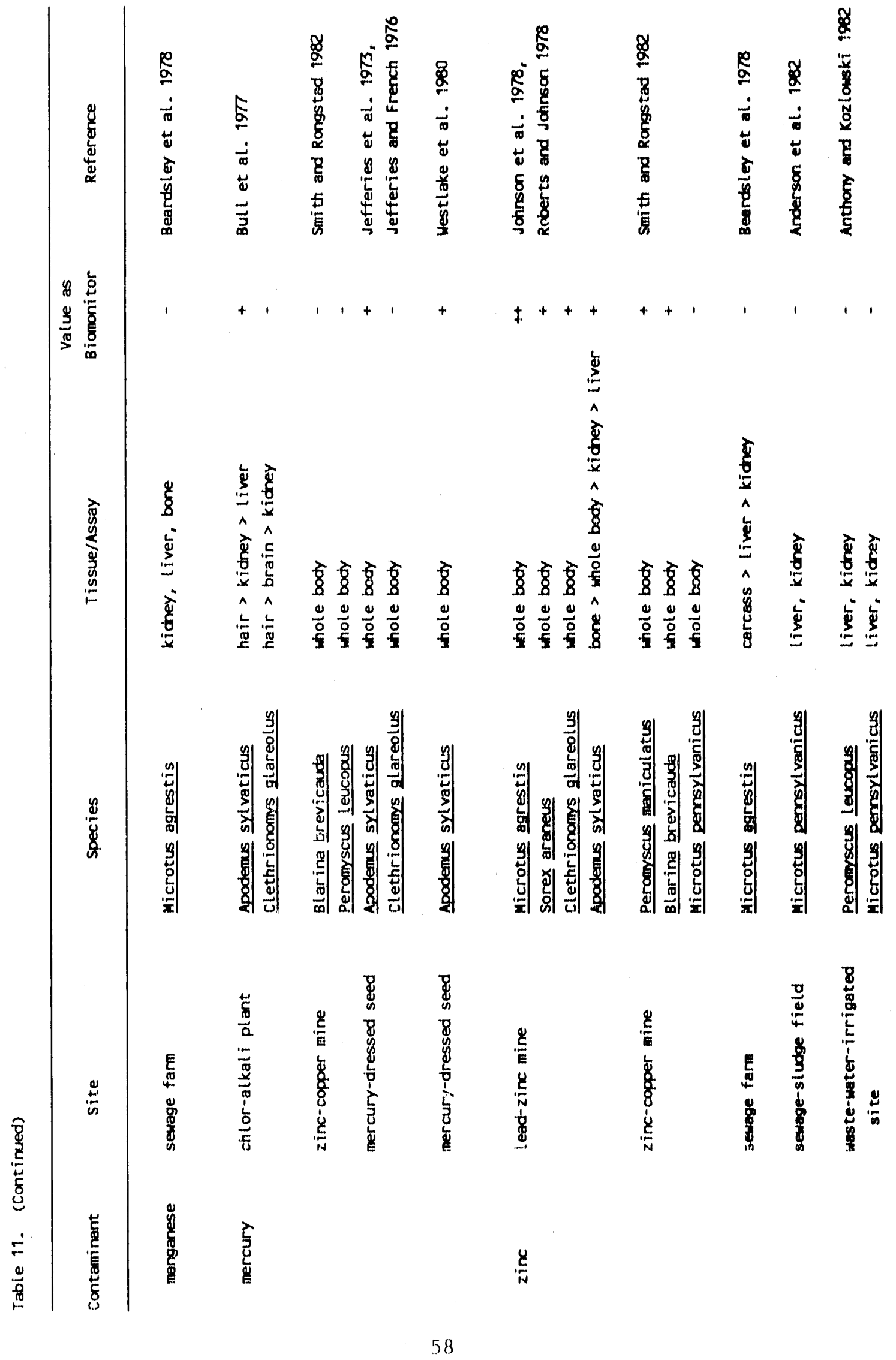




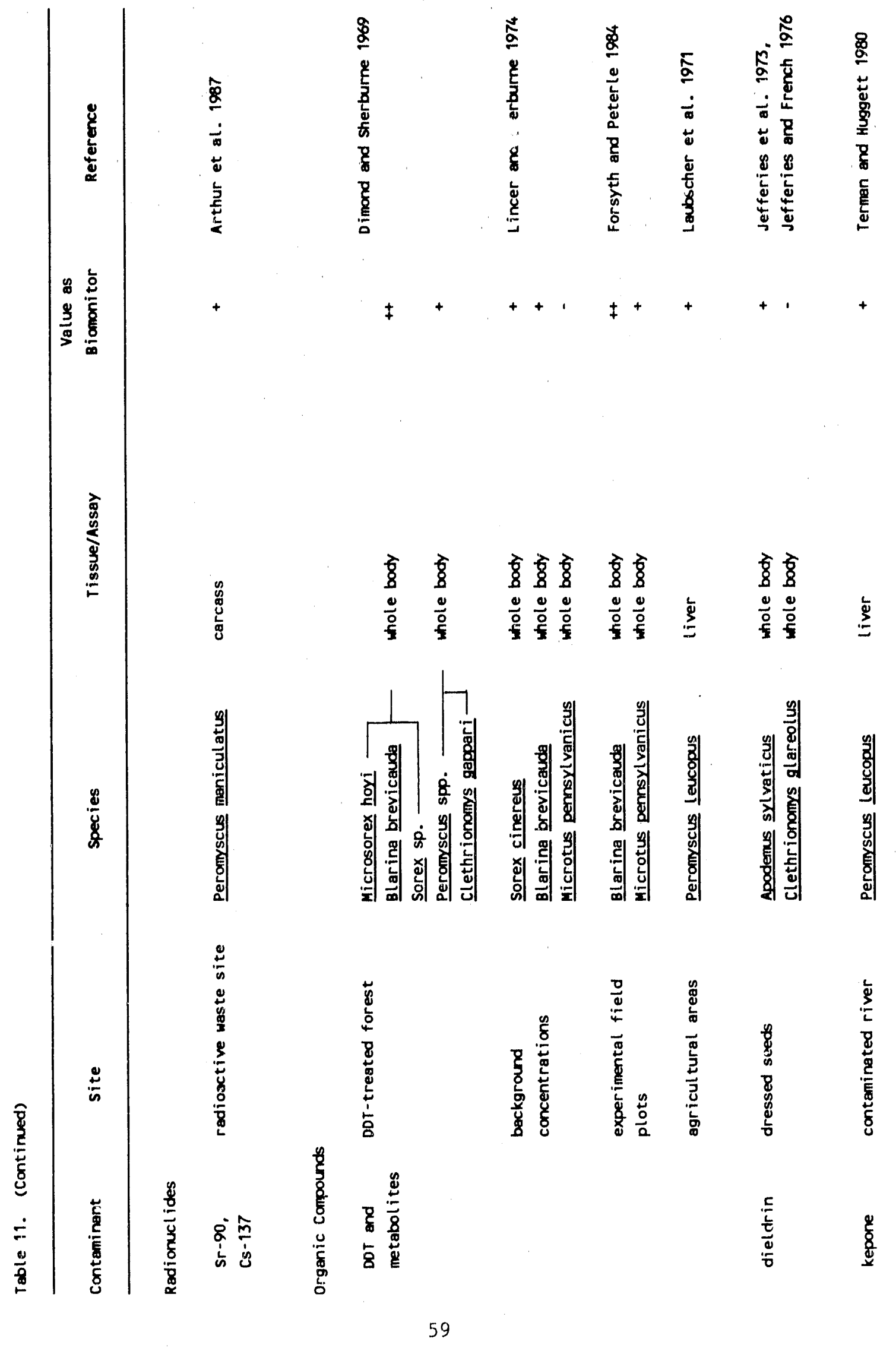




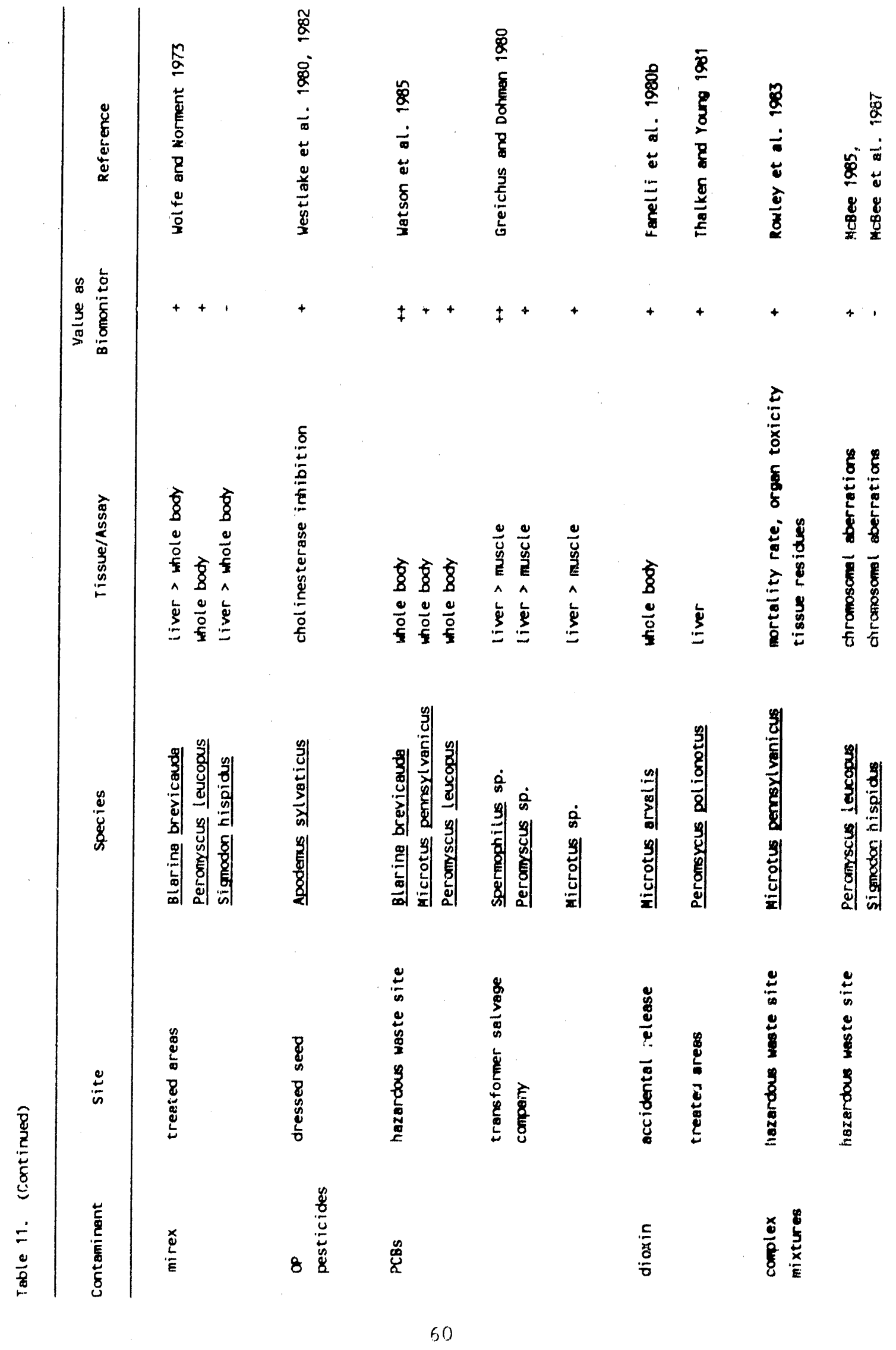




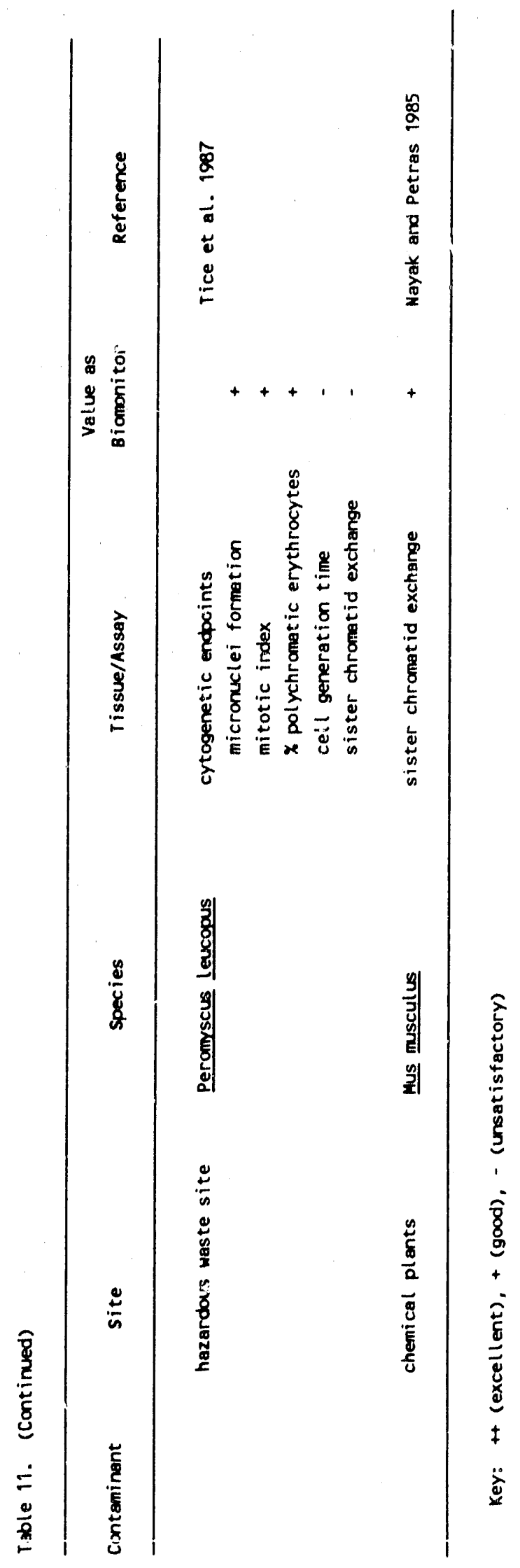


reference and contaminated sites, as well as observations by the respective authors. Where accumulation was high (several orders of magnitude above accumulation at reference sites), bioconcentration above soil values was evident, or differences between contaminated and reference sites were statistically significant, species were ranked as excellent monitors $(++)$. Where differences in accumulation between contaminated and reference sites were apparent, but statistics were not provided or too few animals were trapped to make comparisons, species were ranked as good monitors $(t)$. Where there were no differences between contaminated and reference sites or where data was insufficient, the notation $(-)$ is used. Where several species were studied at the same site, a comparative evaluation was mada, with species ranked in order of decreasing ability to serve as biomonitors. Not all studies employed the primary target tissues, but where several tissues were studied, they are ranked in order of contaminant concentration. For arsenic, chromium, cobalt, manganese, and nickel, not enough information was available to make such determinations.

Food is 'e major source of heavy metal, radionuclide, and organic contamiration for these species, and dagree of tissue contamination can generally be related to concentrations in the diet. In the following discussions the general term shrews refers to members of the genera Blarina and Sorex; mice refers to the genera Peromyscus and Apademus, and voles refers to the genera Microtus and Clethrionomys.

Cadmium in the environment is primarily associated with soil. It was not shown to accumulate in vegetation; concentrations in vegetation were always less than those of soil. The concentration factor of 
soil: invertebrates was approximately 1. Cadmium is present in invertebrates such as earthworms and insects, the primary food items of carnivorous species. Accumulation of cadmium in small mammals was generally highest in the kidney and this tissue appears to be the most suitable for monitoring studies. For the mouse and vole, concentration factors of kidney:soil or kidney:invertebrates were similar and ranged from 0.5 to 1.5 . An exception was at a copper-cadmium alloy plant where cadmium was deposited directly on the vegetation. Here concentration factors of kidney:soil and kidney: vegetation were 2.7 and 11.7, respectively, for the vole. For the shrew, accumulation was greatest in the liver, followed by the kidney. Concentration factors for the liver and kidney compared to soil or invertebrates ranged from 15 to 33 . It is interesting to note that the mean concentrations of cadmium in the kidney and liver of the shrew at the reference site were greater than the mean concentrations for the other two species at the contaminated site. Cadmium also accumulated above soil and invertebrate concentrations in the liver and kidney of the mole, a predator of invertebrates, especially earthworms.

Copper in animal tissues accumulated above reference concentrations at highly contaminated sites. An exception was one sewagetreated area where copper in the liver of the vole $\underline{M}$. agrestis was more than twice that at a reference site and copper in herbage, the main foodstuff, was also more than twice reference values. At the active copper smelter site, the copper concentration in vegetation was up to 47 times that of vegetation from a reference site while copper in the kidney of $\underline{M}$. agrestis was higher by only a factor of two and the same 
as reference values in liver tissue. Copper accumulation was greatest in the shrew ( $\underline{\mathrm{S}}$, araneus) followed by the vole (ㅆ. agrestis) and the mouse ( $\underline{A}$. sylvaticus) in decreasing order of tissue accumulation. The copper concentration of invertebrates was higher than that of vegetation, 343-569 ug/g compared to $153-375 \mathrm{ug} / \mathrm{g}$, and the shrew eats a greater weight of food than the vole, making the copper intake much greater for the shrew. Reference vaiues were also high for shrews. Copper translocation to the seeds of vegetation was low, making the diet of the mouse $\underline{A}$. sylvaticus the lowest in copper of the three species trapped at this site. Concentrations of copper in soil, vegetation, and invertebrate compartments were not measured at the zinc-copper mine. Based on these few studies, copper uptake was well regulated and where accumulation took place, choosing a monitoring species depended on the degree of contamination, route of deposition, and food concentrations. Liver and kidney were the primary target tissues for copper.

At roadside sites where lead is deposited on both soll and vegetation, all species collected were usable as monitors for this metal. There was a positive relationship between traffic density and tissue or whole-body accumulation and an inverse relationship between distance from the road and tissue or whole-body concertrations. For sites at which shrews were present, highest tissue concentrations were present in these species compared to mice and voles. At several roadside sites, shrews were more abundant than mice, indicating that roadside grassy areas are suitable habitat for shrews but not mice. The ranking of species as biomonitors at roadside sites can be corre- 
lated with food habits. The high food intake of shrews and the concentration of lead in insects, its primary food items, contribute to the high body burdens. Lead from automobile exhaust is deposited on the grasses, the primary food of Microtus spp., contributing to their positive ranking as monitors. The grassy edge along roadsides is not the primary habitat of the mice, Peromyscus spp. and $\underline{A}$. sylvaticus and their lower body burdens may reflect the short time they spend in this part of their home range.

At other sites contaminated with lead, shrews were either not abundant or not considered for study. At a site where they were present, lead levels were higher in voles than in shrews or mice, reflecting the high uptake of lead by grassy vegetation compared to invertebrates and seeds. In two studies in urban areas, rats were used as monitors of lead contamination, indicating the usefulness of this species in areas where other small mammals axe usually absent.

Although lead preferentially accumulates in bone, only half of the studies used bone as the monitoring tissue. Where bone was used, the highest accumulation value of all tissues was reported, $672 \mathrm{ug} / \mathrm{g}$ in bone of $\underline{A}$. Sylvaticus at a metal smelter waste site (Johnson et al. 1978). Whole body, kidney, and liver tissues were also suitable tissues for biomonitoring at all but sewage-treated sites.

At two sites where mercury was present, either as emissions from a chlor-alkali plant or as mercury-dressed seeds, the body burdens in mice and voles were similar. The area around the chlor-alkali plant was not highly contaminated, and although both species showed statistically significant increases compared to their respective reference 
areas, a site with a higher degree of contamination might produce a more definitive result. An orchard treated with phenylmercuric acetate 1.tkewise had a low concentration of mercury in the soil and animal tissues were not processed for mercury. Mercury was analyzed in whole bodies and hair, kidney, and liver tissues, but too few studies were available to choose one target tissue.

Zinc, an essential element, is regulated in living organisms and thus is not usually a suitable contaminant for biomonitoring. At derelict mine sites where the mean soli zinc concentration was 21,000

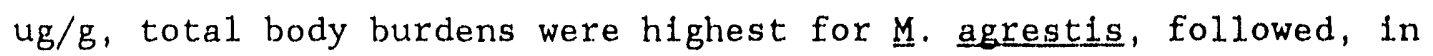
order, by $\underline{\mathbf{S}}$ araneus, $\underline{\mathrm{C}}$. glareolus, and $\underline{\mathrm{A}}$. sylvaticus. Zinc concentrations were higher in cover vegetation, the diet of the vole, than in invertebrates. Whole-body concentrations at contaminated sites were never more than a factor of 1.6 greater than those at reference sites. At a zinc-copper mine where concentrations were not measured in soil or diet compartments, mean whole-body concentrations were about two times greater at the contaminated site for three species, with concentrations in $\underline{P}$. maniculatus being slightly higher and less variable than in $\underline{M}$. pennsylvanicus. Only two $\underline{B}$. brevicauda were trapped. Most studies used whole body measurements; zinc did not bioconcentrate in liver or kidriey tissues.

Deer mice were the only species trapped in sufficient numbers at radioactive waste sites in a study to evaluate their usefulness as monitors. This species was a good monitor of both strontium-90 and cesium-1.37. Although carcass concentrations were used in this study, some sources indicate that other tissues, such as bone for strontium 
and soft tissues for cestum, might be better targets for radionuclide monitoring.

Higher concentrations of DDT and its metabolites were present in shrews than in voles at an experimental field plot and in areas previously treated with DDT for pest control. Shrews accumulated DDT residues in excess of concentrations in their stomach contents at the field plots, but had lower concentrations than in one of their primary food items, Coleoptera, at the other site, and the residues decreased with time.

Shrews were not abundant at other sites where organic wastes were present. Thus, in spite of accumulating the highest concentrations of mirex and PCBs in two studies, their scarcity would make biomonitoring difficult if it were not for the presence of other suitable species. Several species of peromyscus, common to diverse habitats, were reliable monitors of organic contaminants including kepone, TCDD, mirex and some complex mixtures. Peromyscus leucopus was present in numbers great enough for statistical analyses at two sites contaminated with complex mixtures. At both sites they gave positive results in cytogen. etic assays. Additional investigations with this species, utilizing biochemical assays as well as tissue residues are in order. Thus, a successful small-mammal monitoring program requires experience and knowledge regarding target mammals and contaminants in order to design and iraplement a meaningful program.

As discussed, fooc was the major source of contaminants at most of the study sites. Feeding group or trophic level of the species collected were generally positively related to the degree of tissue 
contamination. Thus, while the potential for monitoring at a site depends to some degree on the chemical and biological characteristics of the contaminant and the species present at the site, a generaliza. tion about food habits and capacity to biomonitor can be made. A classification of trophic level of the small. mammals studied and value as a biomonitor as established in Table 11 indicates that insectivorous small mammals (shrews) were the best sentinels for all contaminants (Table 12). Metals and organic compounds accumulate in this trophic level by direct food intake such as ingesting soll-containing earthworms, and through food chain accumulation by ingesting contaminant rich carnivorous beetles and spiders. Shrews were not tested in cytogenetic assays. Omnivorous specles such as mice and rats were suitable for many contaminants. Herbivorous species such as vol.es were in many cases unsuitable except when contaminants were accumulated by or deposited directly on vegetation in aerosol form such as emissions from refineries, smelters, and automobile exhaust.

Limitations to biomonitoring

As noted throughout the foregoing discussions, there are several problems with the use of small mammals as biomonitors. The most obvious drawback is the limited population sizes, including the lack of a suj.table biomonitaring species, at some sites. Insectivorous species such as the Soricidae (Sorex and Blarina) are widely distributed, but they are generally more selective in their habitat preference than are the Cricetidae or Muridae, and are either far less abundant than other species or more difficult to trap. In many studies highest contaminant concentrations were recorded in the Sorlcidae, but only one or two 
Table 12. Relationship of diet to biomonitoring sultability of small mammals collected at contaminated sites.

\begin{tabular}{|c|c|c|c|}
\hline \multirow[b]{2}{*}{ Contaminant/Assay } & \multicolumn{3}{|c|}{ Trophic Level } \\
\hline & Insectivorous & Omnivorous & Herbivorous \\
\hline \multicolumn{4}{|l|}{$\begin{array}{l}\text { Heavy Metals/ } \\
\text { Residue analysis }\end{array}$} \\
\hline Soll adsorbed & ++ & + & - \\
\hline Aerosol deposits & ++ & + & + \\
\hline $\begin{array}{l}\text { Organic Compounds/ } \\
\text { Residue analysis }\end{array}$ & ++ & + & + \\
\hline $\begin{array}{l}\text { Complex Mixtures/ } \\
\text { Cytogenetic assays }\end{array}$ & & + & \\
\hline
\end{tabular}

Key: ++ - excellent, + - good, - - unsatisfactory.

specimens were trapped, making statistical analysis impossible. Also, the Cricetidae and Muridae species can be raised and tested in the laboratory, while the carnivorous shrews are more difficult to maintain.

Although not noted in the tables, there was often an extremely high variability of endpoints (high standard deviations of the mean) stemming from uneven distribution of the contaminant or a small area of contamination with varying home range overlap of the contaminated area. To some degree, age, sex, and season of the year may play a part in bioaccumulation. In the few cases where these parameters were considered, results were usually equivocal. At mine sites and other sites where a mixture of metals were present, antagonistic action between the metals may take place. An antagonistic action between cadmium and zinc 
has been supgested, but much actons are not: well. documented (Hammond and Beld ton 1 (y) 30$)$.

Not all. specles aro pood sentinels. Food hablts and habltat of anch spertes to a latge doyroe determine contact with the contaminant. 'he nonblologlcal matrlx fn which the contaminant is present - alr, water, or sold as woll as the contanlnants's presence in biota that axe lluks tn food chalns vegetation and invertebrates - are fimportant cons lderations for determining the most appropriate species.

Advantages of stomont torfing

The most: 1mportant advantape of blomonitorfing is that critical information can be oftalned on the sources, bioavallablifty, and impact: on biota of chemfol contaminants. Furthermore, bfomonitorlng can be more cost-effective than analysis of a large number of soll, water, and vegetation samples. Uncontanfnated sltes and sltes with the potential for contamination can be routinely montored for $\theta$, dence of contamlnant: mlgatlon, finally, blomonltoring can help establish priorities tor stle cleanup.

For orgaridc compounds, fncluding undeftned, complex mixtures, life history studies and cytogenetic assays using an abundant, widely distributed, opportunlstite feeter such as the genus peromyscus appears to be a promlatng line of Luvestigation for evaluation of exposure to hazardous wastess. The use of restdue andidyes are also of value, but they do not demonstrate the effect of the contambant on the organtsm or population. Further Investigation usting cytogenetic assays as an Indicator of hazard assessment is needed. Also the usefulness of 
abundant, widely distributed herbivorous genera, such as Microtus, as montors needs further investigation.

An asset to the use of insectivorous and herblvorous species instead of the carnivorous shrews is the ease with which they can be ralsed and investigated in the laboratory. In several cases laboratory colonies were used to conflrm results of investigations in the fleld. Tíce et al. (1987) compared cytogenetic endpoints among wild P. leucopus from reference and contaminated sites and laboratory colonies. More laboratory investigations to support effects observed in the field, such as the association between lead exposure and intranuclear Inclusion bodies, would allow a better assessment of potential effects at a site, and would help to establish criteria for priorltization of hazardous sites for cleanup. 
T.T.T. BIOMONTIORTING S'LUDTIS A'T ORNI.

Introduction

As stumarized in Chapter II, the data on biomontorting of many contaminants such as heavy metals, radionuclides, and organic chemlcals 1s sparse, The situation at ORNL provfdes a unique opportunfty for: such studies in that several sites on or near the ORNL reservation are contaminated with the three types of contaminarits considered. The area also has a diverse rodent fauna that can be used to lnvestigate comparative uptake and accumulation of these contaminants.

Organic chemicals, fncluding polycycific aromatic hydrocarbons (PAHs), released to the environment are of concern because many of them, such as benzo[a]pyrene (BaP), are known carcinogens. Suess (1976), using data from 1966-1969, estimated the yearly emisstons of BaP in the Unfted States to be 1300 tons, the greatest contribution coming from coal combustion. BaP levels tend to be higher in urban than suburban areas. A review of the literature on benzolalpyrene concentrations fin the environment reveals that 1ittle research on its fate in the terrestrial environment has been done (Edwards 1983).

Although PAHs such as BaP are both 1 pophllfo and persistent, they genera1ly do not accunulate to a large extent in mamals. Bap is raptdy metabolized to more than twenty metabolltes fn mamallan systems. Some Bap metabolites have been shown to covalently bind to cellular: macromolecules fncluding DNA and proteln (koreeda et al. 1978 , Gelboin and T'so 1978) and as such are a potential indlcator of PAH exposure. These binding properties also provide a conventent approach 
co isolation and measurement of the metabolites (Rahn et al. 1982). Of the BaP metabolites formed, two isomeric diol epoxides are very active in binding to DNA and hemoglobin. Upon acid hydrolysis of tissues, the diol epoxide adducts are released as tetrols. These tetrols can be separated by high performance liquid chromatography (HPLC) and detected jow fluorescence analyis. There is a dose-response relationship w. ween the amount of $\mathrm{BaP}$ applied to the skin of mice and the occurrence, 24 hours later, of BaP adducts to DNA and hemoglobin (Shugart 1985).

Unfortunately, results of laboratory studies in which large doses of a chemical are adninistered over a short period of time are of questionable value for extrapolation to the long-te:m low-level exposure that is likely to occur in the environment. There are no published investigations of the titers of BaP addusts in small mammals ingesting $\mathrm{BaP}$ as part of their diet in their natural habitat. Application of the above method to small mammals collected in the field would allow such measurements to be made.

Elevated levels of mercury in the environment occur as a direct result of human activity. The major sources of mercury releases to the environment are combustion of fossil fuels; mining and reprocessing of gold, copper, and lead; operation of chlcr-alkali plants; and disposal of batteries and fluorescent lamps (National Research Council :978, Eisler 1987). As a result of these localized environmental increases, elevated concentration of mercury $(>3.9 \mathrm{ug} / \mathrm{g})$ ar rssent in biological samples. As discussed in Chapter II, eleval roury concentrations have been documented in small mammals in the vicin:ty of a chlor- 
alkali plant (Bull et al, 1977), but concentrations in all tissues were below the $3.9 \mathrm{ug} / \mathrm{g}$ that Eisler (1987) considered evidence of contumina. tion.

Mercury has no known biological function and its presence in living organisms is potentially hazardous. The toxic effects of mercury, especially methyl mercury, are well documented (Hammond and Beliles 1980). Except for seeds treated with alkyl mercury fungicides, most mercury released to the envirorument is in the inorganic form. While inorganic mercury poisoning is of less concern than methyl mercury poisoning, elemental. or inorganic mercury released to the environment can be biomethylated, especially uncer anaerobic conditions.

The primary effect of exposure to inorganic mercury is on the central nervous system where it can produce neuropsychiatric symptoms such as tremors (Hammond and Beliles 1980). The kidney is the primary target organ for inorganic mercury $\left(\mathrm{Hg}^{2+}\right)$ where it probably causes tubular obstruction.

Mercury can bioconcentrate in organisms and biomagnify through food chains (Eisler 1987). Concentrations in animal tissue from uncontaminated sites average $<0.07 \mathrm{ug} / \mathrm{g}$ (National Research Counci] 1978). As noted in Chapter II, there are only a few studies available on mercury concentrations in tissues of small mammals. Most of these studies report concentrations from only one location and orly occasion. ally report concentrations in the soil or vegetation where the aninals were captured. Little or no mention is given to the effects of mercury on wild mammals (Wren 1986a). 
Over the past three decades, a large amount of radioactiva waste material has been generated from nuclear research and technology. Appropriate storage of this material is of prestut and future concern. Improper storage or burial of such waste, particularly if it comes into contact with fluctuating water tables or migrates into nearby surface waters, may result in widespread environmental contamination. Small mammals may come into contact with contamination through surface contact with soil and water and through their burrowing activity. They may also serve as a means of radionuclide transport from the disposal area, both through emigration and as prey for larger animals.

Strontium-90 is a beta-emitting fission product of nuclear weapon detonations and is produced in the fuel cycle of nuclear power reactors. Because of its presence in fallout from nuclear weapons testing and its relatively long half-1.1fe (28 years), its toxicity has been extensively studied in the laboratory. Strontium, as a metabolic analog of calcium, is readily absorbed from the gastrointestinal tract and lungs, into the bloodstream and deposited in bone. Chronic ingestion results in leukemia and bone tumors in experimental animals (Hobbs and McClellan 1980). Strontium is also taken up by vegetation. Little information on the uptake and effects of strontium-90 on wildlife populations is available.

Extensive aquatic and groundwater monitoring studies have been undertaken on the ORNL reservation to determine the extent anc impact of existing contamination (Boyle et al. 1932). Contaminants in sediments in the vicinity of the Department of Energy's Y-12 plant in Oak Ridge have also been characterized (Hoffman et al. 1984). These 
studies provided information for selection of contaminated and refer ence sites. From these prelfminary studies, mercury, strontium-90, and several organics including Bap were shown to be present in the soll at several sices; however, no terrestrial biomonitoring studies have been performed in recent years at these sites.

The primary objectives of this part of the study were to determine if, through tissue and residue analyses, resident small mammal populations could serve as indicators of the presence of environmental. contaminants at ORNL field sites and to determine which species axe the best sentinel species for specific contaminants. This investigation focused on three areas: (1) the bioavailability of the contaminants as evidenced by tissue residues and biochemical markers; (2) the evaluation of each species as a sentinel of exposure, and (3) the relation. ship between habitat and food habits and the consequences for biomoni. toring studies. The conclusions reached in chaptex II, that highest concentrations of contaminants are found in insectivores, that orni. vores are good sentinels under most conditions, and that herbivores cun serve as sentinels under specialized conditions will be tested. To aid in the accomplishment of these objectives, an effort was made to docunent or determine experimentally the presence of these contaminants in soil and vegetation at the sites.

Another goal of the study was to assess the utility of measuring, concentrations of BaP adducts bound to hemoglobin as a toc: for monitoring the exposure of wildife populations to mutagenic or carcinogenic compolinds that are persistent in the environerit but do not accumulate jn animal tissues. Feeding studies with Bap were 
conducted in the laboratory because information on the accumulation of this contaminant during subchronic exposure was not avallable.

\section{Materials and Methods}

A11 reagents were HPLC grade and were purchased from Burdick \& Jackson, Muskegon, Michigan, except where otherwise noted. BaP (Gold Label, 99.98 pure) was purchased from Aldrich Chemical Co., Milwaukee, Wisconsin, and $7,10-14 \mathrm{C} \mathrm{BaP}(29.7 \mathrm{mCi} / \mathrm{mmol})$ was obtained from Amersham Corporation, Arlington Heights, Illinois. Both of these chemicals were used in the analysis of soll for BaF. For the subchronic feeding study with mice, purified BaP tetrols were obtained from Dr. Lee Shugart (Biology Division, Oak Ridge National Laboratory). They were prepared by the hydrolysis of the corresponding BaP diol-epoxide isomers followed by HPLC separation (Shugart et al. 1985). Female C3H mice were obtained from the colony maintained by the Biology Division at ORJVL. The mice were approximately 12 weeks old and were housed under climate-controlled conditions $\left(20^{\circ} \mathrm{C}\right)$ with free access to water and Purina 5010-C chow. Glass-distilled water was used for all analytical procedures, except in the HPLC system, where HPLC grade water (Burdick \& Jackson) was used.

Laboratory Study

Groups of 20 female $\mathrm{C} 3 \mathrm{H}$ mice, 10 per cage, were administered doses of 2, 10, or 50 ug of BaP dissolved in corn oil by intragastric intubation, twice weekly, for 7.5 weeks. A group of five controls was administered the corn oil vehicle orily. Following the third dose, three mice from the 50 ug dose group were anesthetized and sacrificed 
each week by exsanguination (heart puncture) and their blood was analyzed for BaP metabolites. After the fifth dose (2.5 weeks), three mice from the 10 us, bus group and after the ninth dose (4.5 weeks), four inte flom the uld age grom were killed and analyzed weekly for Bap herogloblu adducts Using, HFLC separation and fluorescence detection.

bescription of study sites

East Fork Poplar cleek.

East Fork Poplar Creek (EFPC) originates at the Y-12 plant, one of three facilities in Oak Ridge managed by Martin Marietta Energy Oystems, Ine, for the U. S. Department of Energy. This creek is the recelving strean for industrial effluent from the $\mathrm{Y}-12$ plant and may also jacej wastes as it flows through a commercial area of Oak Ridge. 'he cresk is $23.7 \mathrm{~km}$ in length from New Hope Pond, a waste settling pond at the east and of the Y-12 plant, to its confluence with Poplar creek. For much of its length, EFPC flows through the city of oak Ridge. Near kilometer 17, about four kilometers from the Y-12 plant, the floodplain is low and the creek periodically overflows, depositing sediment. The floodplain at this point contains abundant vegetation including sneezeweed (ㅂelenium autumnale), jewelweed (Impatiens capensts), and grasses (Sorgum halepense); there is a boxtifer (Acer regundo) canopy and an old field adjacent to the creek. Animals were trapped at this site during 1986 and 1987.

From 1950 to 1963, mercury used in a 1ithium separation process was released from the Y-12 plant into the creek. Approximately 1,080 metxic tors $(1,000,000 \mathrm{~kg})$ could not be accounted for at the plant and 
may have been released into the creek (Bashor and Turri 1986). It was recently estimated that $80,000 \mathrm{~kg}$ may be present in the floodplain (Turner 1987). Analyses of the soll by researchers at Oak Ridge Associated Universities Indicated that most of the mercury in floodplain sediments is present as inorganic salts (Bashor and Turri 1986). Soll concentrations of up to $2,600 \mathrm{ug} / \mathrm{g}$ have been measured on the site (Gist 1986).

Benzo[a]pyrene and other organic contaminants are also present in the floodplain (Hoffman et al. 1984). The source of BaP is uncertain-but it might have been released as runoff from coal piles or ash from the Y-12 steam plant at the same time as the mercury spills (Munger 1988). Concentrations of $\mathrm{BaP}$ are higher in the floodplain adjacent to the Y-12 plant than at downstream sites. Animals trapped during 1985 and 1986 were tested for BaP metabolites; animals trapped during 1986 and 1987 were analyzed for mercury residues. Radionuclides are present at extremely low levels and, according to Hoffman et al. (1984), can be excluded from consideration as important contaminants. Thus, EFPC served as a negative reference site for radiontclides in small mammals and a positive reference site for mercury and BaP.

\section{White Oak Like}

White Oak Lake (WOL) is used as a settling lake for radionuclides and other contaminants in effluents from ORNL. Small mammals were trapped under a power line on a ridge above the lake. The right of way contains dense grass (primarily Festuca sp.) and is bordered by shrubs and deciduous trees. This site became a reference area for the EFPC 
BaP studies once it became evident that only background concentrations of BaP were present. Trapping took place from June to August 1986.

\section{White Oak Creek}

White Oak Creek (WOC) flows through the ORNL complex into wOL before entering the clinch River. Discharges from a number of settling ponds contaninated with radionuclides (strontium 90, cesiun137, and cobalt-60) enter the stream at several locations. The stream flows near several solid waste storage areas (SWSAs) and trenches (Figure 1), where contaminated surface and ground water from the these areas can enter the stream. Mercury is also present in the creek and i.ts floodplain.

Two weirs are present on wOC downstream of the main plant and serve as convenient references for designating locations of sampling sites. The areas above the weirs are characterized by low lying flat flelds covered with grassy vegetation. At the point where woC enters WOL, the vegetation consists of shrubs with a canopy of boxelder and willow (Salix sp.). Animals were trapped at kilometer 2.1 (WCK 2.1), the point where WOC enters WOL; above Weir 2 (kilometer 27 [WCK 2.7]); and above Weir 1 (k1lometer 3.4 (WCK 3.4]) during the spring and summer of 1987. The WCK sites contain both mercury and strontium-90.

\section{Solid Waste Storage Area- -4}

Solid Waste Storage Area-4 (SWSA-4) comprises an area of approxi.mately 10 ha on the Oak Ridge Reservation. Between 1.951 and 1.959 SWSA4 was used as a low-level radioactive waste disposal site for wastes generated both on- and off-site (Melroy et al. 1986). Trenches 


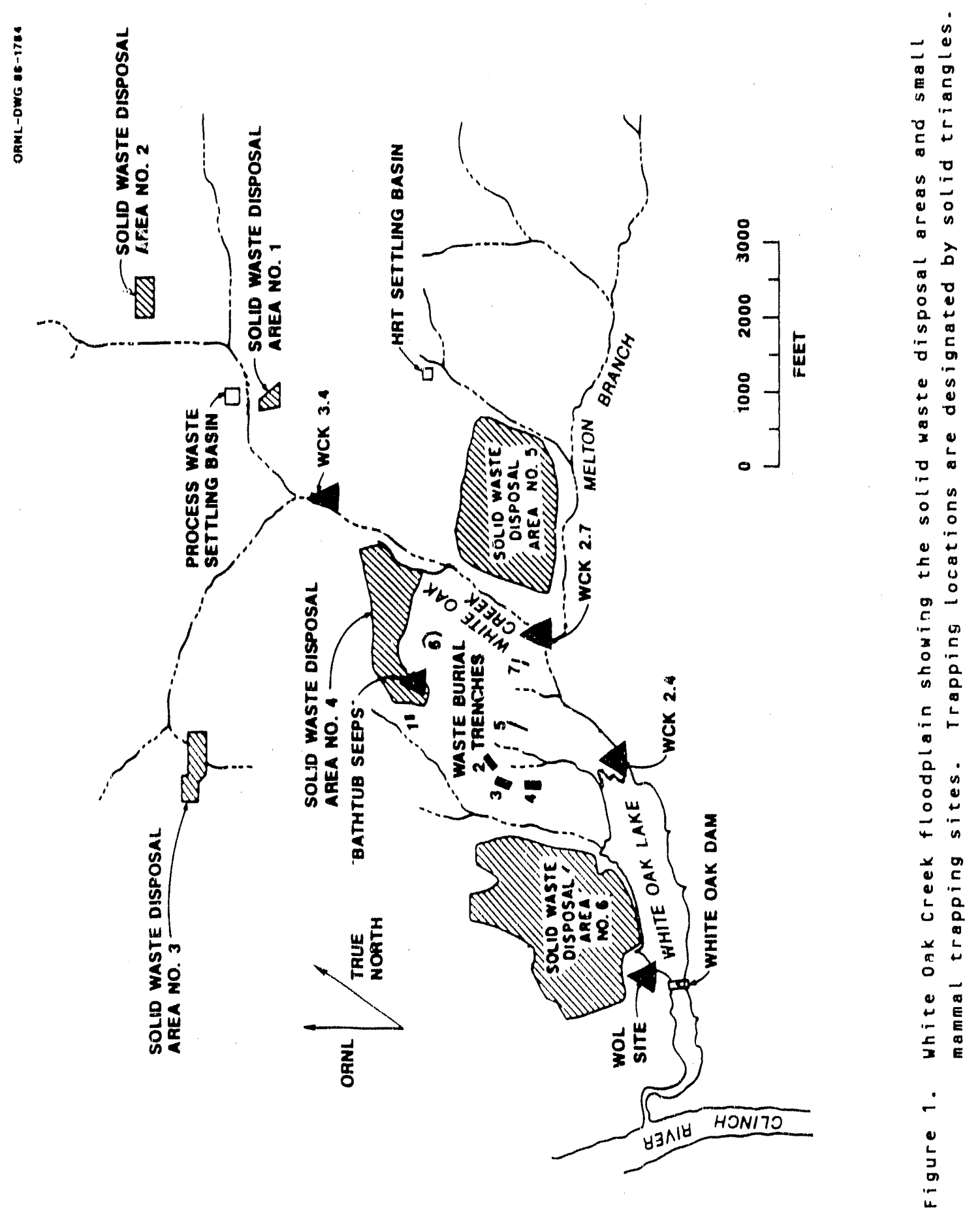


and auger holes were used for disposal of the wastes. Alpha-eintteing wastes were covered with concrete, and the beta- and gamna-emitting wastes were covered with a natural soli cover (Lomenick and Cowser 1961). The burfal ground was covered with uncontaminated fill and closed in 1959. It is now majntained as a grassy fleld. A bank covered with brush and trees separates SWSA.4 from a sinall tributary of WOC .

During periods of rain or high water table, the trenches at: SWSA-4 fill up and overflow, producting surface contamination. This phenomenon is referred to as the bathtub effect and the seeps are referred to as "bathtub seeps." According to recent stidies (Melroy et a1. 1986), up to $150 \mathrm{~Bq}$ of strontium-90 per gram of soll. (dry wt) is present at the surface. Ground level GM survey meter readings range up to 25.000 counts per minute (Figure 2) (Garten and Lomax 1987). Animals were trapped in the area of the bathtub seeps during the riping and summer of 1.987 to determine whether radionuclides were taken up by resident fauna. SWSA-4 served as the negative reference area for the mercury study.

Contaminants in soils at the study sites are sumnarized in Table 13. Based on the study of Hoffman et a1. (1984), EFPC was considered contaminated with $\mathrm{BaP}(+)$. Background concentrations, (-) of BaP are $\leq 10 \mathrm{ng} / \mathrm{g}$ (Edwards et al. 1983). Based on the previous discussions, background concentrations of mercury (-) are $<1.0 \mathrm{ug} / \mathrm{g}$, contaminatei (t) refers to 1 to $20 \mathrm{ug} / \mathrm{g}$, and highly contaminated $(+t)$ refers to $>20$ $\mathrm{ug} / \mathrm{g}$ (up to 2,000 ug/g at EFPC according to Gist 1986). Background concentiations of strontium-90 (-) are usually undetectable to very low 


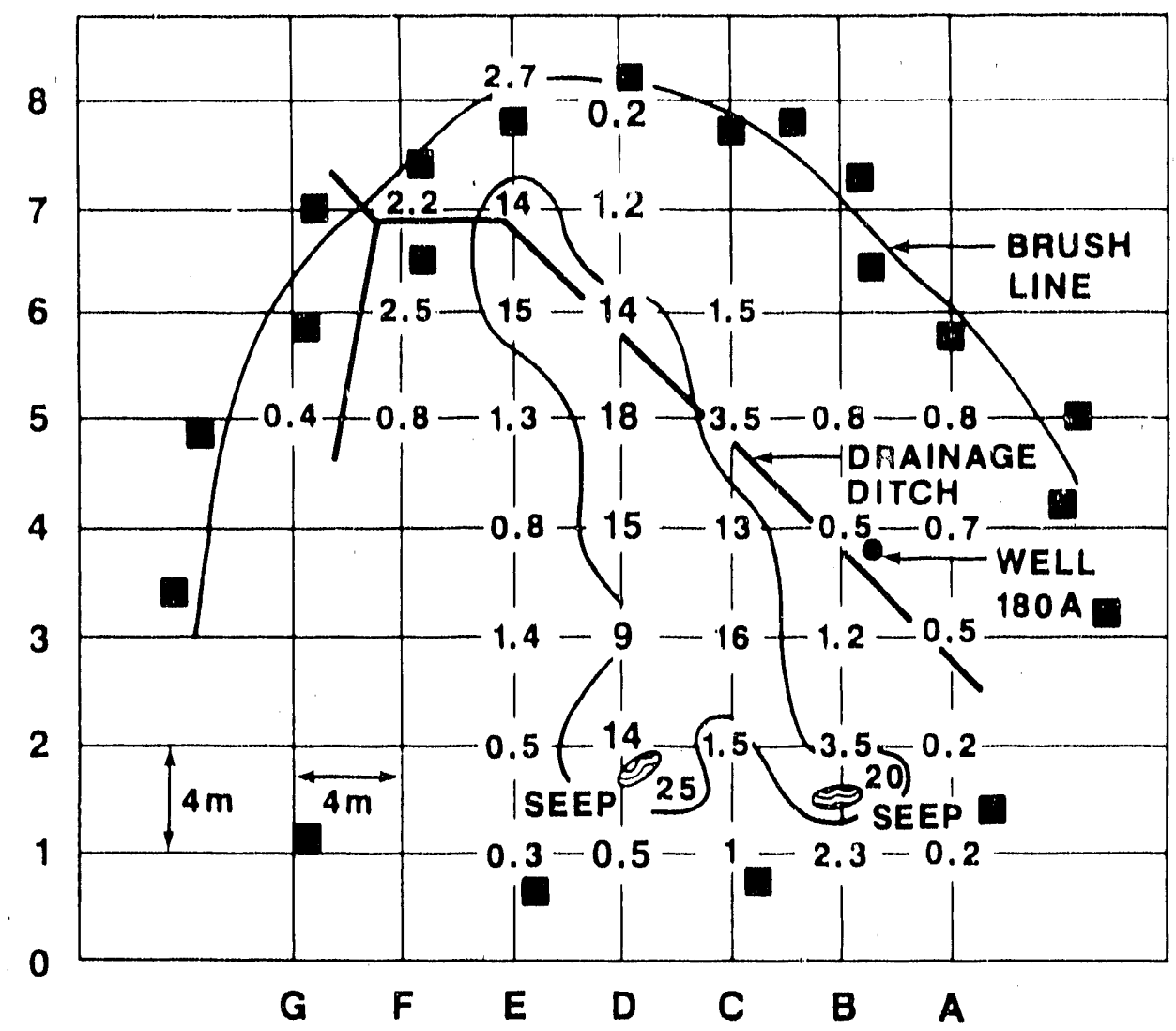

Figure 2. Solid Waste Storage Area-4 showing ground-level gamma readings, the seeps, and smal-mammal trapping sites. Gamma readings are in thousands of counts/minute. Traps are designated by solid squares.

$(<0.008 \mathrm{~Bq} / \mathrm{g}$ at EFPC according to Hoffman et al. 1984); highly contaminated sites such as SWSA-4 (+t) contain up to $150 \mathrm{~Bq} / \mathrm{g}$ of soll (Melroy et al. 1986). Contaminated sites (t) such as the WCK floodplain contain 2 to $11 \mathrm{~Bq} / \mathrm{g}$ (Garten and Lomax 1987).

Collection of Study Animals

Small mammals were trapped using $22.9 \times 7.6 \times 7.6 \mathrm{~cm}$ Sherman live traps baited with surflowel seeds and/or fish. Larger mammals were trapped with $66 \times 22.9 \times 22.9 \mathrm{~cm}$ Tomahawk live traps placed along 
Table 13. Contanfnants present at the East Fork Poplar Creek (EFP()), White Oak Lake (WOL), White Oak Creek (WOC), and Solid Waste Disposal Area-4 (SWSA-4) study sites.

\begin{tabular}{|c|c|c|c|}
\hline Site & Benzo[a]pyrene & Mercury & stront 1uil-90 \\
\hline EFPC & + & +1 & - \\
\hline WOI. & - & - &. \\
\hline WOC & - & + & + \\
\hline SWSA 44 & + & - & $+t$ \\
\hline
\end{tabular}

Key: +t (highly contamfnated), + (contaminant present:), - (background)

strean and lake banks. Traps were labelled with codes for each study site. Apples were found to be the best bait for larger animals such as groundhogs and muskrats. All traps were checked each morning and trapped animals were transported to the laboratory for weighing, spectes deterintnation, and blood collection.

\section{Collection of Soil. Samples}

Surface sol. samples $(0.3 \mathrm{~cm})$ were collected at trap locations at all. sites. At EFPC samples werz also taken with a soll corer at depths up to $140 \mathrm{~cm}$. Depostts of a grey to black substance, whlch probably Included mercury salts and carbon-rich material, were visible in the cores at a depth of $20-40 \mathrm{~cm}$. Sampling locations were noted by trap location or by coordinates with respect to a permanent markar (tree or: grid stake) at the site. Soll was anal zed for mercury and Bap.

Analytical Methods

Benzolalpyrene:

Soll samples were collected at the selected sites for analysis for BaP. Samples were air dried to a constant weight and sleved (2-mm 
mesh) befire extraction. In preliminary studies, Bap and other organics in soil and vegetation from the EFPC site were determined by the Analytical Chemistry Division at ORNL. Subsequent extractions and analyses were conducted in our laboratory using the procedures below. BaP was separated from soll by soxhlet extraction according to EPA Method 3540 (U. S. Environmental Protection Agency 1982), A11 extractions were performed in duplicate. Five-gram soll samples were mixed with five grams of anhydrous sodium sulfate (to absorb water) and five grams of Ottawa sand (to promote solvent percolation), placed in a glass extraction thimble, and extracted using $150 \mathrm{ml}$ of solvent placed in a $250-\mathrm{mL}$ round-bottomed flask (Kimax). Preliminary analyses using 1008 cyclohexane, acetone: hexane (1:1), toluene: methano1 (10:1), or 100 m methylene chloride as solvents showed that methylene chloride was a satisfactory solvent. Extractions were carried out for 18 hours at a temperature appropriate for the solvent(s) used. Solvent volumes were reduced to $1 \mathrm{~mL}$ on a Buchi Rotovapor $-\mathrm{R}$ rotoevaporator.

Because colored contaminants were present in the extract, cleanup steps developed by Edwards (1985) were employed to clarify the samples. The $1 \mathrm{~mL}$ of anajyte was added to $30 \mathrm{~mL}$ of cyclohexane which was pipetted into a separatory funnel containing $60 \mathrm{~mL}$ of dimethyl sulfoxide (DMSO). BaP was extracted into the DMSO by gently inverting the funnel several times. Since the reaction is exothermic, pressure was allowed to escape periodically. The DMSO, present as the lower layer, was drained into a clean separatory funnel to which $120 \mathrm{~mL}$ of cyclo. hexane and $120 \mathrm{~mL}$ of water were added. Most of the interfering colored contamirants remained in the original cyclohexane. Addition of water 
10 the biso allows re-extracton of the bap trito the cyclohexane. Bap

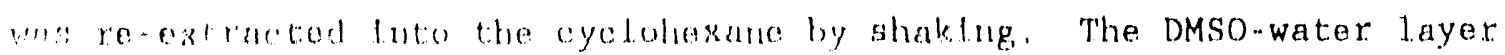

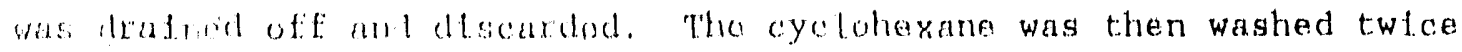
whth 50 III, of water, phaced lin a flask, drled whth sodlum sulfate, pouted Lnto a round bottomed flask, and reduced in volume to $3 \mathrm{~mL}$ using tha sotoevapotator. The concentrate was ftltered through st1 tea seppak

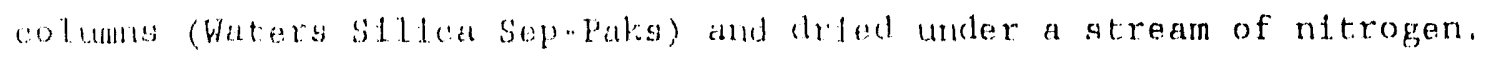
The sanples were dissolved in $1 \mathrm{ml}$ of $100 \mathrm{~g}$ methanol and filtered through a Cameo nylon filter Into 1-ml brow bottles (Shamrock Glass Go.) for storage and analysis.

Twanty-1.t samples wore lujeoted lnto a HPLC nystem (Perkin-Elmer) equipped with a fluorescent detector (Perkin.Elmer LS Serles 4 ) and a Hewlett. Packard Integrator. Samples were eluted with $100 \%$ methariol; detector settings were excltation, 355 nm and emission, $410 \mathrm{~nm}$, Bap was quantified using peak letghts of standald solutions.

In whet to detemine llat percent recovery of Bap using the

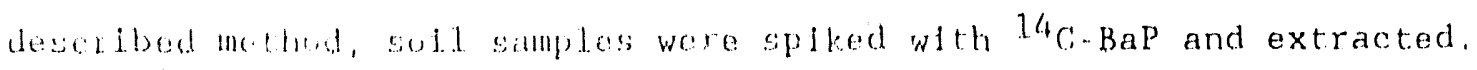
Samples were counted on a Tricarb 2000 CA Jiquid Scintillation Counter. Because recoveries were conststent for soll samples from a specific site, but varled umong soll types, the organle carbon content of the

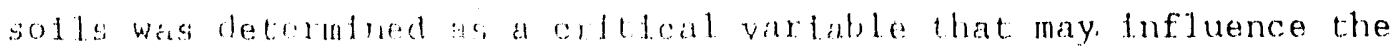

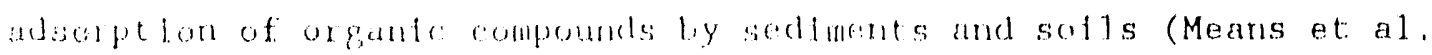
1980). Total catbon, whlch alosely appostmates the organtc carbon content of soil, ars measurul on a liCr WR 1?. Carbon Determinator. No clear cut relationshlp was found between ogganic carbon content of soll. and percent Bap rresvery (stout 1988). Slnce Bap recoveries were 
consistent for soil from each site, but differed among sites, an internal ${ }^{14} \mathrm{C}$-BaP spike was used for each soil analysis and corrections were made for percent recovery. Analyses were done in duplicate using methylene chloride as the solvent.

\section{Benzola]pyrene metabolites}

BaP metabolites were separated from hemoglobin and quantified according to a modification of the method of Shugart (1985). Small mammals were anesthetized with Metofane (methoxyilurane) in a closed jar. The thoracic cavity was opened and a sample of blood was taken by heart puncture using a $1-c c$ syringe treated with an anticoagulant (sodium heparin). Blood was taken from the tails of larger animals such as muskrats by venous puncture. The blood sample was placed in a heparinized plastic microfuge tube and centrifuged (Eppendorf Microcentrifuge) at 11,000 RPM for two minutes to isolate red blood cells (RBCs). The plasma was discarded and the cells were rinsed twice, by gentle inversion, with $2 \mathrm{~mL}$ of sterile saline ( 0.98 sodium chloride). The samples were centrifuged again and the saline was discarded. The RBCs were pipetted with water into a 15 -mL conical glass centrifuge tube (total liquid volume of $4 \mathrm{~mL}$ ) and lysed with $0.2 \mathrm{~mL}$ of carbon tetrachloride. The cells were vortexed intermittently over a 30 -minute period to ensure lysis. The samples were then centrifuged at 20,000 RPM for 20 minutes $\left(4^{\circ} \mathrm{C}\right)$ in $15-\mathrm{mL}$ plastic centrifuge tubes to separate hemoglobin from the cell debris (Beckman $T J-6 R$ ). Three $\mathrm{mL}$ of the hemoglobin was then transferred to a $10-\mathrm{mL}$ vial and a drop of the hemoglobin was set aside for later hemoglobin analysis. Two $\mathrm{mL}$ of water were added to the sample in the $10-\mathrm{mL}$ vial, followed by $50 \mathrm{uL}$ of 
consentrated HC1 (the solution darkens at this point). The samples were heated in an oven at $80^{\circ} \mathrm{C}$ for four hours. The acid-induced release of the diol-epoxide metabolites of BaP, covalently bound to hemoglobin as adducts, results in tetrol products.

The tetrols were separated from the hemoglobin by extraction through a series of three columns: a SepPak $\mathrm{C}_{18}$ cartridge (Waters Associates) attached to a 5-cc syringe, a Bond Elute PH cartridge (Analytichem International) with a 3-cc piggyback syringe, and a column prepared from diethylaminoether cellulose (DEAE) (Whatman DE 32) in an empty Bond Elute cartridge. The DEAE was suspended in sterile water and added to the cartridge to a height of $2.5 \mathrm{~cm}$. Bubbles were removed by agitation. Liquid was forced through the latter cartridge by attachment to a Micro-Vac vacuum apparatus. All columns were prewashed with $2 \mathrm{~mL}$ of $100 \%$ methanol, $2 \mathrm{~mL}$ of $20 \%$ methanol, and $2 \mathrm{~mL}$ of water before use. The water-suspended tetrols were added to the syringes or cartridges, the water removed by vacuum, and the cartridges were washed with two $2-\mathrm{mL}$ water rinses and two- $2 \mathrm{~mL} 208$ methanol rinses. The tetrols were removed from the columns with two-2. $\mathrm{mL} 1008$ methanol. washes which were collected in test tubes. The tetrols were taken to dryness under a gentle stream of nitrogen and then resuspended in $2 \cdots \mathrm{mL}$ water for placement on the Bond Elut and DEAE columns. After removal from the DEAE column and drying, the tetrols were dissolved in $1 \mathrm{~mL}$ of methanol, filtered through a Cameo nylon filter (attached to a $1-c c$ glass syringe) into 1 mL brown glass bottles, which were capped with teflon lined caps. 
For field-collected animals, the tetrols were separated and quantified on the same HPLC system as used for BaP in soil. A 20-uL sample was injected into a HPLC-equipped fluorescence detector. The metabolites were separated by an isocratic reversed-phase technique using a Vydac colurn and methanol:water $(50: 50)$ as the eluent. Detector settings were excitation, $246 \mathrm{~nm}$ and emission $370 \mathrm{~nm}$. In the laboratory study, a DuPont 850 Liquid Chromatograph coupled with a Schoeffel FS 950 fluorometer was used. The column was an ODS 10u Zorbex. Two metabolites of $\mathrm{BaP}$, the tetrols $( \pm)-7,8,9,10$-tetrahydroxy$7,8,9,10$-tetrahydro-benzo[a]pyrene, referred to as tetrols I- 1 and II-2, are detected and serve as indicators of BaP exposure in the animals. A Hewlett-Packard Integrator was used for the graphical display. Standard solutions of tetrols were prepared and run on the system to determine retention times. Pooled blood from unexposed animals was spiked with a known amount of tetrols and taken through the process to determine percent recovery. The lower level of detection was $10 \mathrm{pg}$.

BaP tetrol values were calculated using peak heights of known standard solutions run at the same time. Values were normalized to hemoglobin content of the sample. Hemoglobin samples were prepared by a modification of the method of Sigma Chemical Company (1982). Sample absorbencies were read at $540 \mathrm{~nm}$ on a Beckman Spectrophotometer Acta C111.

Mercury

Air-dried soil samples and fresh kidneys from small mamnals were analyzed for total mercury by the ORNL Analytical Chemistry Division. 
Samples were wet digested in nitric and perchloric acids and detected as a cold vapor by atomic alworption spectroscopy.

Because the levels of mercury in tissue were unknown before analysis and because data from literature searches indicated they might: be very low, kidney samples from several animals of the same species collected at EFPC (the positive reference site for $\mathrm{Hg}$ ) were pooled to make a sample weight of one gram. When analysis indicated that mercury levels were extremely high compared to the level of detection ( 40 $\mathrm{ng} / \mathrm{g}$ ), individual kidneys were submitted for each animal. In addition, kidneys from laboratory-reared (control.) mice were analyzed to establish background for uncontaminated animals. The raw data were converted to natural logarithm values and differences between reference and contaminated site means were tested using the Student's t-test.

\section{Strontium-90}

Strontium-90 concentratiors in bone were obtained by detecting the Cerenkov effect from high energy beta particles produced by yttrium-90, a daughter product of strontium-90 (Haberer 1965, Larsen 1981).

Hindlimbs and crania of sacrificed animals were cleaned of muscle rissue, dried overnight at $100^{\circ} \mathrm{C}$, and ashed at $900^{\circ} \mathrm{C}$. Weights of wet, dried, and ashed samples were recorded. The bone samples were ground, successively digested in $4 \mathrm{M}$ hydrochloric and $8 \mathrm{~N}$ nitric acid, dried, cleared with 308 hydrogen peroxide, and then dissolved in plastic vials containing $20 \mathrm{ml}$ of water and a few drops of hydrochloric acid. The vials were counted for Cerenkov radiation in a Packard Tri-Carb Scintillation Spectrometer (Model 3002). The samples were corrected for a counting efficiency of $55 \%$. The limit of detection was $0.33 \mathrm{~Bq}$. 
Bones from laboratory-reared mice were used as control samples; in addition, blank samples were taken through the procedure as process controls. Counts were transformed by taking square roots before parametric statistical analysis methods were applied. Differences between mears were tested using the Student's t-test.

$$
\text { Results }
$$

\section{Laboratory Study}

Only the anti-(t)-benzo[a]pyrene metabolite (tetrol I-1) was found in blood samples of mice treated subchronically with $\mathrm{BaP}$, as indicated by the single peak present at the same retention time (18 minutes) as the tetrol I-1 standard (Figure 3), A peak corresponding to Tetrol II2 (retention time 35 minutes) was not present. In the high and middle dose groups (50 and $10 \mathrm{ug} /$ treatment), the amount of BaP tetrol I-1 measured in the blood decreased over the experimental period. In the 50-ug dose group, concentrations of adduct fell from $7.23 \mathrm{pg} / \mathrm{mg}$ hemoglobin at week 2.5 to $0.50 \mathrm{pg} / \mathrm{mg}$ hemoglobin at week 7.5 . The 2 and 10 ug dose groups reached equilibrium by the middle of the fifth week, at which time the concentrations were $0.25 \mathrm{pg} / \mathrm{mg}$ and $0.21 \mathrm{pg} / \mathrm{mg}$ hemoglobin, respectively (Table 14). Concentrations in corn oil intubated controls were below the limit of detection.

In addition to one accidental death, five of the 65 mice did not survive to the end of the experiment. Ten of the mice in the treated groups developed large abscesses in the area surrounding the lymph nodes of the forearms; these abscesses made walking difficult. 


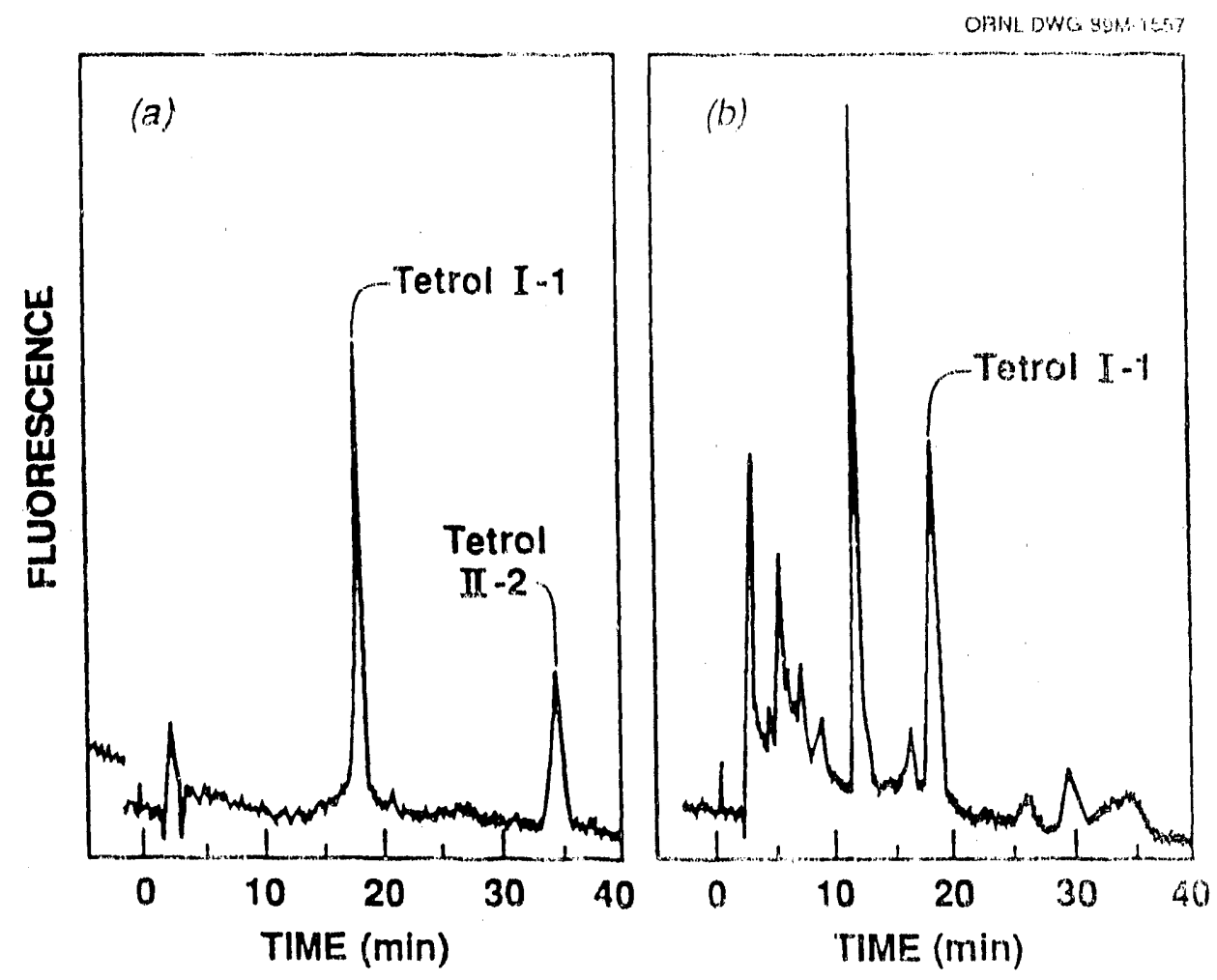

Figure 3. High performance liquid chromatography/fluorescence profiles of (a) standard solution of benzola]pyrene tetrols $I-1$ and $I I-2$, and (b) tetrols hydrolyzed from the hemoglobin of a $\mathrm{C} 3 \mathrm{H}$ mouse following four weeks of treatment with $50 \mathrm{ug}$ of benzola]pyrene twice weekly.

Table 14. Weekly concentrations of benzo[a]pyrene tetrol I-1 metabolite in the blood of $\mathrm{C} 3 \mathrm{H}$ mice fed three dose levels of benzo. [a]pyrene twice weekly in the laboratory. Concentrations in $\mathrm{pg} / \mathrm{mg}$ of hemoglobin.

\begin{tabular}{lccc} 
& \multicolumn{3}{c}{ Administered Dose } \\
\cline { 2 - 4 } Week & $2 \mathrm{ug}$ & $10 \mathrm{ug}$ & $50 \mathrm{ug}$ \\
\hline 1.5 & - & & 7.23 \\
2.5 & - & 1.01 & 1.97 \\
3.5 & - & 1.04 & 4.33 \\
4.5 & 0.58 & 0.62 & 1.29 \\
5.5 & 0.25 & 0.21 & 3.11 \\
6.5 & 0.61 & 0.33 & 2.03 \\
7.5 & 0.50 & 0.37 & 0.50
\end{tabular}


Field Studies

A total of 10 different species of mammals were captured along White Oak Creek, at the Solid Waste Disposal Area-4, above White Oak Lake, and along East Fork Poplar Creek (Table 15). The white-footed mouse, $\underline{P}$. leucopus, was the most common species trapped and was present at all sites.

\section{Description of Study Species}

Fe:omyscus leucopus was the most common species collected in the vicinity of the ORNL reservation. It was found at all sites in habitats of deciduous forest, border areas, and old fields. At EFPC it was present under the boxelder canopy along the creek where vegetation was sparse in spring, but dense by late summer and fall. White-footed mice were not found in the grassy old-field, except at the bases of solitary trees. During a long dry period in summer, it and other species were trapped only close to the creek. At SWSA-4 it was not present in the mowed field, but was trapped along the brush line and in the deciduous forest. This was the only species trapped along the lower expanse of White Oak Creek. At WCK 2.1 the ground cover is similar to that of EFPC; the ground under the boxelder and sycamore canopy is damp, but not marshy. At WCK 2.7, ․ leucopus was trapped in the grassy, dry floodplain adjacent to the creek and along the border of the forest, about 20 meters away. It was not common at the marshy WCK 3.4 area.

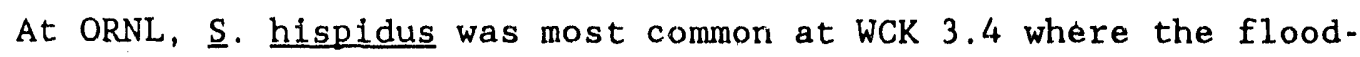
plain is low and swampy much of the year. It was also present at SWSA- 4 in the fall when the grass was not mowed. Surprisingly, the 
Table 15. Species and numbers of small mammals trapped at ORNL study sites during 1986-1988.

\begin{tabular}{|c|c|c|c|}
\hline Site & Species & Common name & Number \\
\hline \multicolumn{4}{|c|}{ East Fork Poplar Creek (EFPC) } \\
\hline & Peromyscus 1eucopus & White-footed mouse & 32 \\
\hline & Blarina brevicauda & Shortall shrew & 1.2 \\
\hline & Sigmodon hispidus & Cotton rat & 1 \\
\hline & Ondatra zibethica & Muskrat & 9 \\
\hline & Datus norveglous & Norway rat & 2 \\
\hline \multicolumn{4}{|c|}{ Whice Oak creek kilometer 2.1 (WCK 2.1) } \\
\hline & Peromyscus lencopus & White-footed mouse & 9 \\
\hline \multicolumn{4}{|c|}{ White oak creek kllometer 2.7 (WCK 2.7) } \\
\hline & Peromyscus leucopus & White-footed mouse & 5 \\
\hline \multicolumn{4}{|c|}{ White Oak Creek kilometer 3.4 (WCK 3.4) } \\
\hline & Peromyscus leucopus & White-footed mouse & 2 \\
\hline & Sigmodon hispidus & Cotton rat & 4 \\
\hline & Relthodontomys humulis & Eastern harvest mouse & 1. \\
\hline \multicolumn{4}{|c|}{ White Oak Lake (WOL) } \\
\hline & Eeromyscus leucopus & White footed mouse & 13 \\
\hline & Blarina brevicauda & Shorttail shrew & 4 \\
\hline & Sigmodon hispidus & Cotton rat & 2 \\
\hline & Microtus ochrogaster & Prairie vole & 1 \\
\hline & Mus musculus & House mouse & 1 \\
\hline \multicolumn{4}{|c|}{ Solid Waste Disposal Area-4 (SWSA-4) } \\
\hline & Peromyscus leucopus & White-footed mouse & 16 \\
\hline & Blarina brevicauda & Shorttail shrew & 3 \\
\hline & Sigmodon hispidus & Cotton rat & 5 \\
\hline & Reithrodoritomys humulis & Eastern harvest mouse & 3 \\
\hline & Microtus pinetorum & Pine vole & 3 \\
\hline & Tamias striatus & Eastern chipmunk & 2 \\
\hline & Mus musculus & House mouse & 1 \\
\hline
\end{tabular}


cotton rat was not present at EFPC with the exception of one animal during three years of trapping. This may have been due to the dryness of the field during the summer trapping periods. No animal was trapped in the old field at a distance of greater than three meters from the boxelder stand.

In this study $\underline{B}$. brevicauda was most common in areas with dense understory vegetation and fallen trees. At EFPC five were trapped within a few meters of a fallen log covered with honeysuckle. They were much less abundant than $\underline{\underline{P}}$. leucopus and had a greater tendency to die in the traps. Trapping success of $\underline{B}$. brevicauda improved when sardines were added as bait to the traps.

At ORNL $\underline{R}$. humulis was found only in grassy areas and was the only species present in the short grass surrounding the seeps at SWSA-4. Other species were caught in numbers too low to consider them as sentinel animals. Microtus pinetorum was the only true herbivore caught. Previous studies reported that pine voles were common on the Oak Ridge Reservation (Dunaway et al. 1971), but only three were trapped at SWSA-4. All three were trapped along the brush border between the grassy area and the deciduous forest. Muskrats, trapped only at EFPC, were tested for BaP metabolites but not for mercury or strontium. Muskrat dens were present (and trapping success was high) where three conditions existed: creeks banks were high; large, solitary trees having root systems that extended down the creek bank were present; and sunny, densely vegetated banks were located nearby. Muskrats slides were observed on the banks. Apples proved to be the best bait for muskrats. This species was nct trap shy and the same 
animal (identified by ear tag) was often trapped on consecutive nights.

Food habits of collected species range from primarily herbivorous

(M. pinetorum) lo primarily insectivorous (B. brevicauda). Other species such as $P$. leucopus are opportunistic feeders ... thefr diets are composed of seasonally abundant items. Food habits of the captured species are summarized in Table 16.

Table 16. Food habits of species trapped at the ORNL study sites.

\begin{tabular}{lll}
\hline Species Herbivorous Omnivorous Insectivorous \\
\hline
\end{tabular}

Microtus pinetorum

Peromyscus leucopus

Sigmcdon hispidus

Reithrodontomys humulis

Blarina brevicauda

$\mathrm{X}$

$\mathrm{X}$

$\mathrm{X}$

$\mathrm{X}$

$\mathrm{X}$

\section{Benzola]pyrene}

Results of soil analyses show that BaP was present at all three sampling locations with the highest concentrations at EFPC (70 ng/g) and the lowest along WCK ( $5 \mathrm{ng} / \mathrm{g}$ ) (Table 17). The chromatographic profile of soll from EFPC shows the complex nature of the chemicals present (Figure 4). Based on a retention time identical to that of the BaP standard in Figure $4(a), 4.00$ minutes, the highest peak in Figure 4(b) was identified as BaP in the field sample. The other compounds in the profile have not been identified.

Only tetrol I-1 was detected in the blood of some animals collected at EFPC. This metabolite was present in muskrats, shrews, and a rat. (Table 18). It was not present in 27 P. leucopus collected at this site or in any species collected at the other sites. 
Table 17. Benzo[a]pyrene concentrations in soll at the East Fork Poplar Creek (EFPC), White Oak Creek (WCK 2.1), White Oak Lake (WOL), and Solid Waste Storage Area-4 (SWSA.4) sites.

\begin{tabular}{lc}
\hline Site & $\begin{array}{c}\text { BaP in so11 } \\
(\mathrm{ng} / \mathrm{g})\end{array}$ \\
\hline EFPC & 70 \\
WCK 2.1 & 5 \\
WOL & 14 \\
SWSA-4 & 35 \\
\hline
\end{tabular}
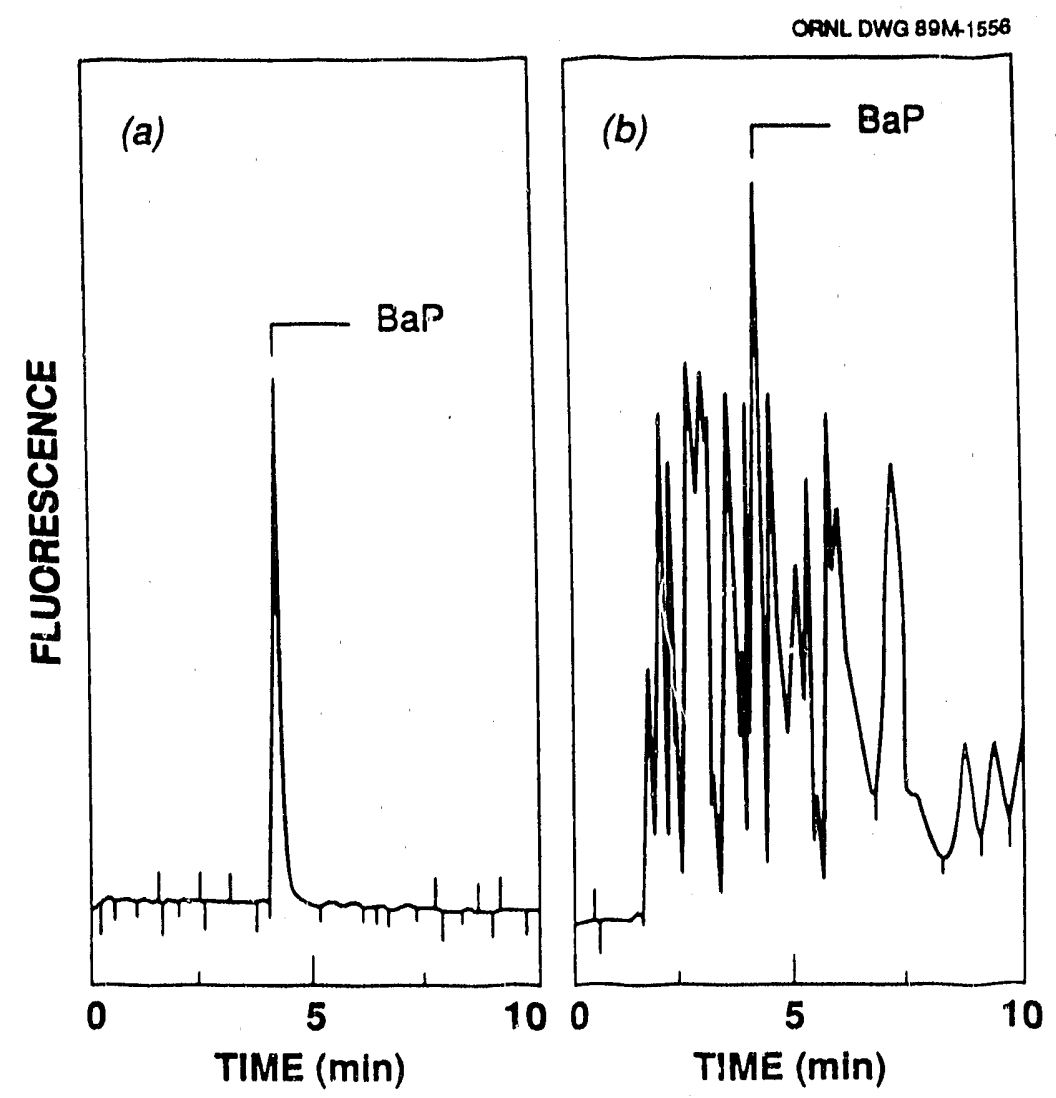

Figure 4. High performance liquid chromatography/fluorescence profiles of (a) standard solution of benzo[a]pyrene and (b) organic compounds extracted from the soil at East Fork Poplar Creek. 


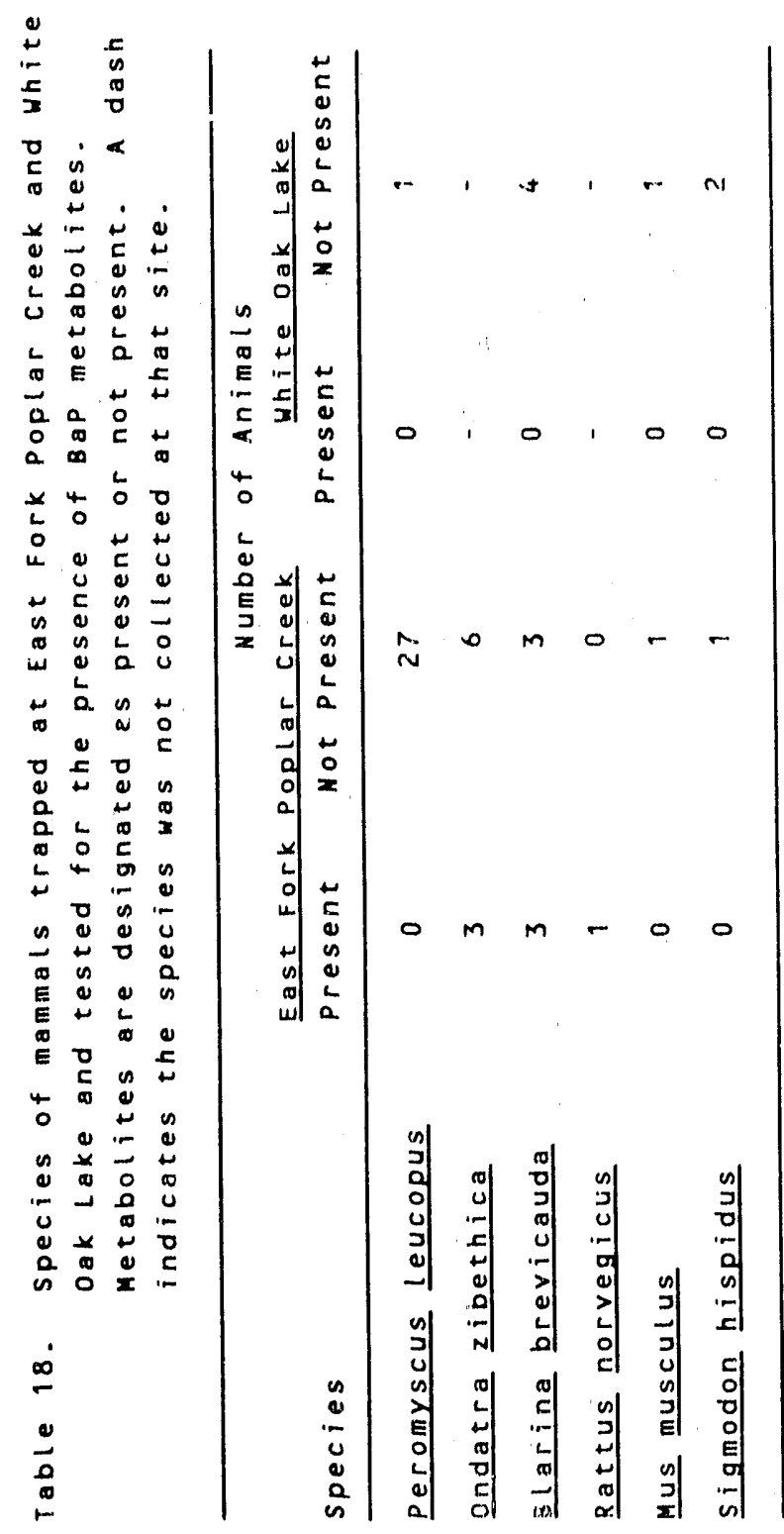


Chromatographic peaks for field-collected animals were not as clearly defined as those from laboratory-raised animals (Figure 5). As in the case of the laboratory-treated mice, only the Tetrol I-1 metabolite was present in the profile. Because of the complex mixture of chemicals found at EFPC, interfering chemicals may be present in the tetrol I-1 peaks. Therefore, concentrations found represent maximum values likely to bis pr:sınt and are reported here as either present or not present.

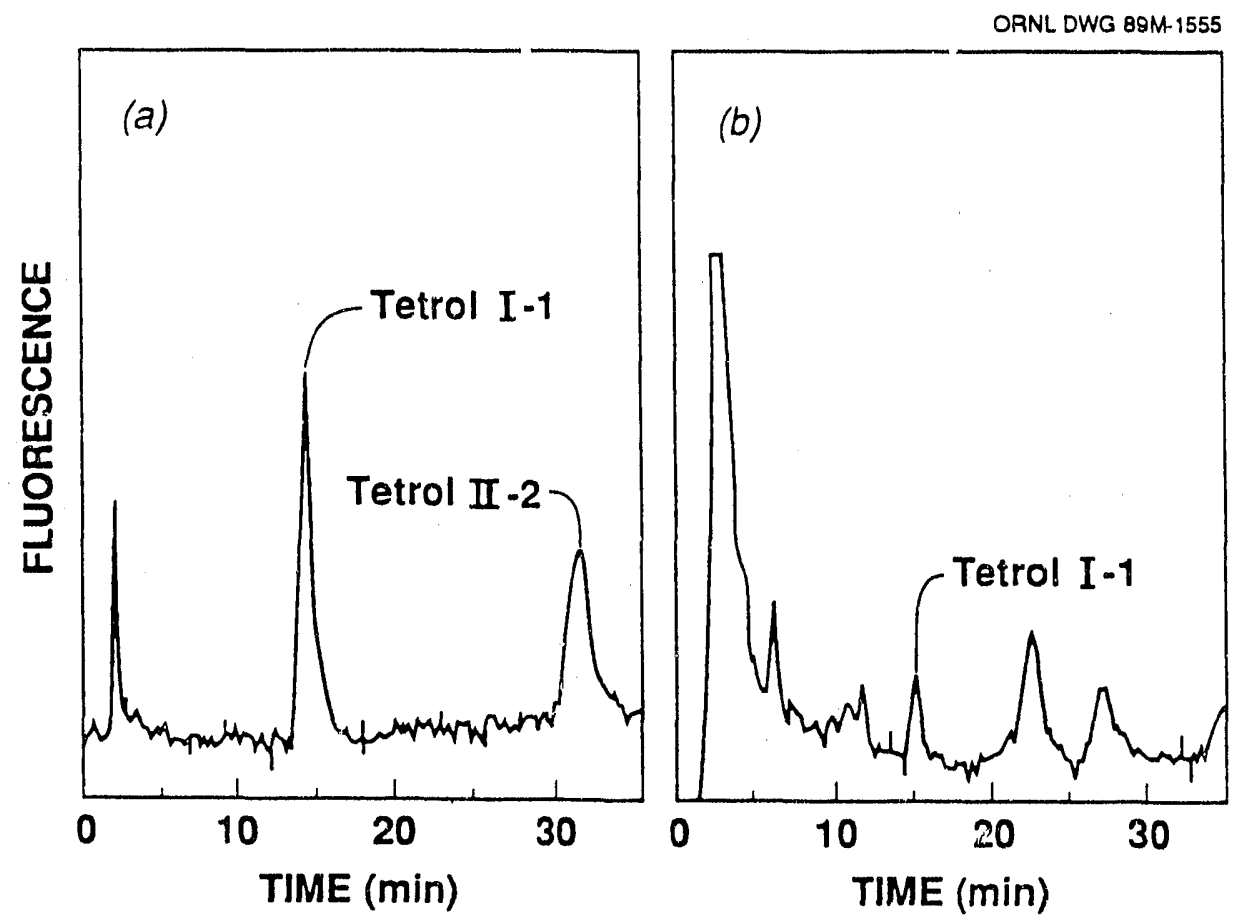

Figure 5. High performance liquid chromatography/fluorescence profiles of (a) standard solution of benzo[a]pyrene tetrols I-1 and II-2 and (b) tetrols hydrolyzed from the hemoglobin of Blarina brevicauda trapped at East Fork Poplar Creek. 


\section{Mercury}

Mercury concentrations at EFPC averaged $348 \mathrm{ug} / \mathrm{g}$ soil in the top three cm (mable 1.9) and $1675 \mathrm{ug} / \mathrm{g}$ at a soj.1 depth of $20.40 \mathrm{~cm}$. Concentrations were lower along White Oak Creek; averages ranged from $0.8 \mathrm{ug} / \mathrm{g}$ at WCK 2.7 to $7.0 \mathrm{ug} / \mathrm{g}$ at WCK 3.4 . Concentrations were lowest at the SWSA -4 reference site, $0.2 \mathrm{ug} / \mathrm{g}$.

Residues of mercury were detected in kidneys $o_{1}$ all mammals collected at the study sites (Table 19). Concentrations for the three species collected at reference sites were $\leq 3.2 \mathrm{ug} / \mathrm{g}$, with highest concentrations in $\underline{B}$. brevicauda. The highest mercury concentrations were found in mammals trappen at EFPC. Similarly, B. brevicauda averaged the highest $F_{g}$ residues in kidney at $137 \mathrm{ug} / \mathrm{g}$ (range: 3.4 to $258 \mathrm{ug} / \mathrm{g}$ ). Concentrations in $\underline{P}$. leucopus, the only species trapped at all sites, and $\underline{S}$. hispidus were also higher than those from WCK or SWSA-4, 4.2 $\mathrm{ug} / \mathrm{g}$ and $6.7 \mathrm{ug} / \mathrm{g}$, respectively, at EFPC vs $\leq 1.8 \mathrm{ug} / \mathrm{g}$ for both species at the other sites. Differences were significant between EFPC and the reference site (SWSA-4) for both $\underline{B}$. brevicauda and $\underline{\text { p. leucopus. No }}$ other species were abundant enough at EFFC to make statistical comparisons. The standaid deviation of the mean wa'i large for all fieldcollected species. The concentration in laboratory mice fed regular laboratory chow was $0.02 \mathrm{ug} / \mathrm{g}(\mathrm{n}=8)$. Wet weight concentrations of mercury in kidney tissue for individual animals are listed in APPENDIX B. Concentrations for air-aried soil samples are listed in APPENDIX $C$. 
Table 19. Mercury concentrations in soil and kidney tissue of small mammals collected on the East F'rk Poplar Creek (EFPC) floodplinin, White Oak Creek (WCK) floodiplain, and Solid Waste Storage Area-4 (SWSA-4) site. A dash indicates the species was not collected at that site.

\begin{tabular}{|c|c|c|c|c|}
\hline \multirow[b]{2}{*}{ Site } & \multicolumn{4}{|c|}{ Hg (ug \g dry weight) } \\
\hline & $\begin{array}{l}\text { Peromiscus } \\
\text { Leucopus }\end{array}$ & $\begin{array}{l}\text { Blarina } \\
\text { brevicauda }\end{array}$ & $\begin{array}{l}\text { 3igmodon } \\
\text { hispidus }\end{array}$ & Soil \\
\hline EFPC & $\underset{(n-23)}{4.2 \pm 4.2^{*}}$ & $\begin{array}{l}137.0 \pm 86.8^{* \star} \\
(n=8)\end{array}$ & $\begin{array}{l}6.7 \\
(n-1)\end{array}$ & $\begin{array}{l}348 \\
(n-2)\end{array}$ \\
\hline WCK 3.4 & $\begin{array}{l}1.4 \\
(n=2)\end{array}$ & - & $\begin{array}{l}1.8 \pm 1.1 \\
(n-4)\end{array}$ & $\begin{array}{l}7.0 \\
(n-2)\end{array}$ \\
\hline WCK 2.7 & $\begin{array}{l}1.4 \pm 0.7 \\
(n=5)\end{array}$ & - & - & $\begin{array}{l}0.8 \pm 0.5 \\
(\mathrm{n}-3)\end{array}$ \\
\hline WCK 2.1 & $\begin{array}{l}0.7 \pm 0.4 \\
(n=9)\end{array}$ & - & - & $\begin{array}{l}2.6 \pm 0.8 \\
(n-3)\end{array}$ \\
\hline SWSA -4 & $\begin{array}{l}1.8 \pm 1.4 \\
(\mathrm{n}=10)\end{array}$ & $\begin{array}{l}3.2 \pm 2.1 \\
(\mathrm{n}=3)\end{array}$ & $\begin{array}{l}0.7 \pm 0.4 \\
(n-5)\end{array}$ & $\begin{array}{l}0.2 \pm 0.1 \\
(\mathrm{n}-6)\end{array}$ \\
\hline
\end{tabular}

* Statistically significant difference compared to reference site (SWSA-4) at $\mathrm{p}<0.01$.

** Statistically significant difference compared to reference site (SWSA-4) at $\mathrm{p}<0.005$. 


\section{Strontium-90}

All field-collected small mammals from sites contaminated with strontium-90 had detectable amounts of strontium-90 in bone tissue (Table 20). At SWSA-4, highest concentrations were found in $\underline{\mathrm{R}}$. humulis (mean: $71.5 \mathrm{~Bq} / \mathrm{g}$; range: $10.0 \mathrm{~Bq} / \mathrm{g}$ to $281 \mathrm{~Bq} / \mathrm{g}$ ). This species was captured in the short grass immediately adjacent to the seeps. Concentrations were elevated for $\underline{\mathrm{S}}$. hispidus trapped at both SWSA- 4 and WCK $3.4(26.5 \mathrm{~Bq} / \mathrm{g}$ and $20.7 \mathrm{~Bq} / \mathrm{g}$, respectively) and for $\mathrm{B}$. brevicauda trapped at SWSA-4 (23.5 Bq/g); strontium-90 was present, but at low concentrations in $\underline{\mathrm{P}}$. leucopus and $\underline{\mathrm{R}}$. humulis trapped at WCK sites. Standard deviations of the mean values were large in all cases. Activities for animals trapped at EFPC averaged close to background. Activities in laboratory-reared mice averaged the same as background (distilled water) blanks and as blanks taken through the entire analytical procedure (12 counts/minute). Concentrations of strontium90 in dried bone tissue of individual animals are listed in APPENDIX D.

Discussion

Small mammals were trapped at several contaminated sites to determine the practicality of biomonitoring at ORNL and to determine appropriate sentinel species for three specific contaminants. The types of species present, the number of individuals of a species, and evidence of uptake by one or more sentinel species trapped at the sites were considered important parameters of biomonitoring. This study documents species-specific uptake of three classes of contaminants by small mammals at chemically contaminated sites. It does not provide 


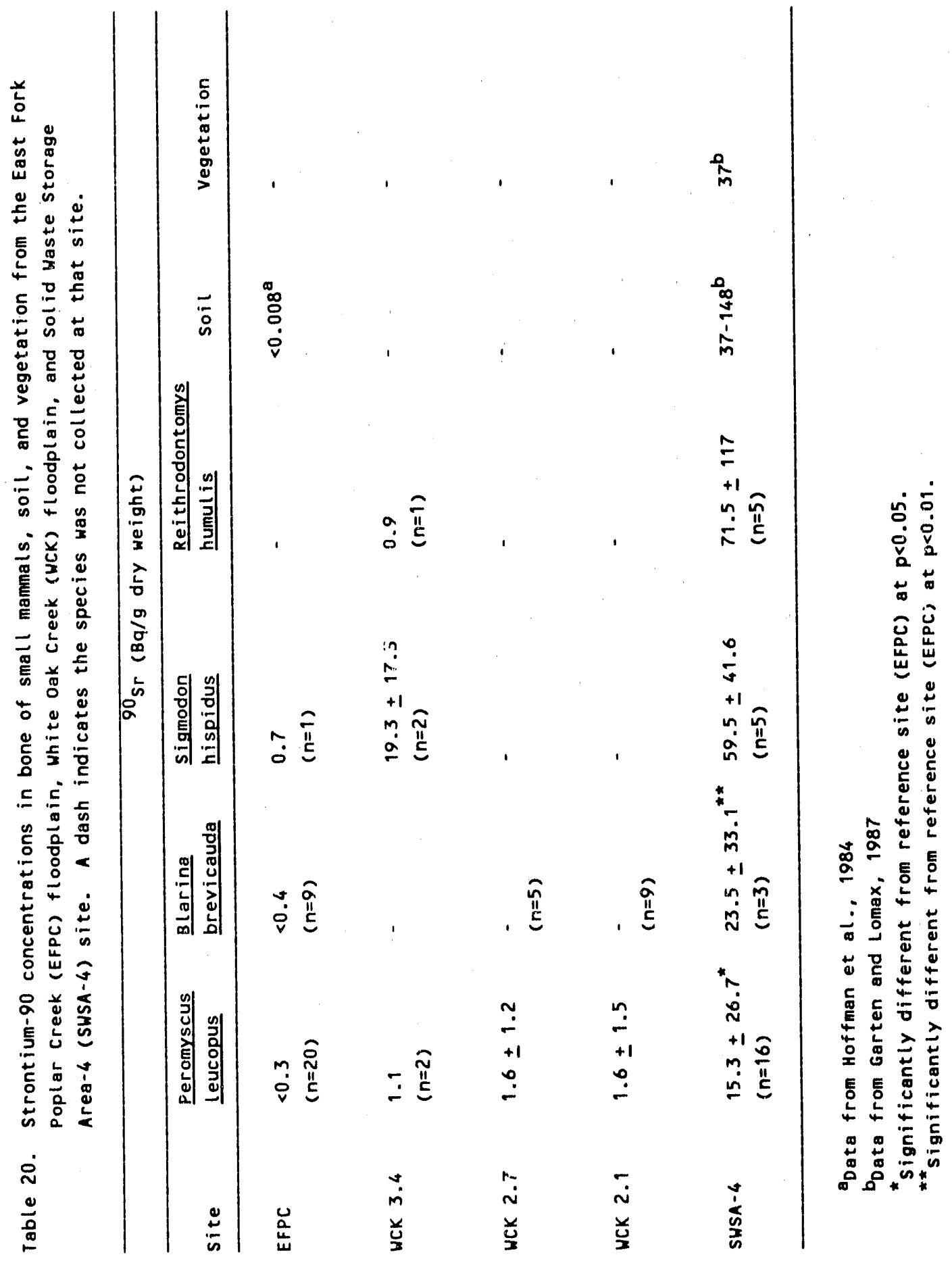


evidence for the utility of using hemoglobin adducts as a measure of BaP exposure.

\section{Benzo[a]pyrene}

More than 50 different chemicals covalently bind to macromolecules in vivo (Calleman 1984, Farmer et al. 1987). These adducts are potential indicators of exposure to the chemicals. In mammalian systems, BaP is rapidly metabolized to more than twenty metabolites (Selkirk 1986). The diol-epoxide metabolites are highly reactive, attaching to macromolecules such as DNA and hemoglobin (Sims et a1. 1974; Koreeda et al. 1978). Following administration of acute doses, the formation of adducts with DNA and hemoglobin is dose-dependent; the adduct with hemoglobin is stable and disappears at the same rate at which red blood cells are naturally destroyed (Shugart 1985). Chronic feeding of $\mathrm{BaP}$ might be expected to result in an fincrease of adducts over time until all available attachment sites on the macromolecules are filled (Osterman-Golker et a1. 1976, Calleman 1984). In this study, however, the number of adducts as measured by picograms tetrol. I-1/gram of hemoglobin decreased with time, reaching a plateau, in the case of the 2 and 10 ug treatments, by the middle of the fifth week.

The reason for the decrease of $\mathrm{BaP}$ adducts with time under this subchronic exposure is unknown, but is of considerable consequence for the use of adducts to monitor for BaP exposure of natural populations of small mammals. The mixed function oxidase system, which metabolizes many xenobiotic chemicals, is inducible in several tissues of $\mathrm{C} 3 \mathrm{H}$ mice, including intestinal tissue (Nebert and Gelboin 1969, Dunn 1981, Griffin et a1. 1986). Initially, concentrations of hemoglobin-DNA 
adducts are high following exposure. But, following induction of the enzyme system, $\mathrm{BaP}$ is rapidly metabolized in the intestinal mucosa, resulting in formation of reactive metabolites that covalently bind to intestinal cell DNA. Only small quantities of the parent compound are released to the general circulation, resulting in a decrease of the hemoglobin adducts with time. If all mammalian species act similarly, then species at contaminated field sites and in equilibrium with the contaminant in their environment would have similar low, close to undetectable, levels of BaP tetrol I-1 adducts in their blood.

Although $\mathrm{BaP}$ is nearly ubiquitous in terrestrial systems, plant uptake is usually low. In a literature review by Edwards (1983) the concentration ratios for $B a P$ in vegetation $\backslash B a P$ in soll were found to range from 0.0001 to 0.33 . Preliminary studies for this report revealed that the concentrations of $\mathrm{BaP}$ in roots, stems, and leaves of vegetation collected at the EFPC site were an order of magnitude less than those in the soil in which the plants were growing (unpublished data).

The present study shows that BaP is present in the soll at all three study sites. The highest level was found at EFPC $(70 \mathrm{ng} / \mathrm{g})$, but this level was low compared to highly contaminated areas cited by Edwards (up to $191 \mathrm{ug} / \mathrm{g}$ ). Because plant concentrations of BaP are at least an order of magnitude lower than soll concentrations, uptake from sediment or soil would be the most likely route of food chain transfer to small mammals. Results of blood analyses showed site and species differences in exposure to BaP. Low concentrations of a BaP metabolite were found in the blood of several species of mammals that have close 
contact with the sediment or soil including $\underline{B}$. brevicauda, which burrows into the ground and eats earthworms and insects contaminated with soil, and muskrats (‥ zibethica), which feed primarily on sediment-contaminated vegetation along the creek bank and sometimes feed on invertebrates found on the stream bed. BaP adducts were not detectable in omnivores such as $\underline{P}$. leucopus which ingest 1fttle soll.

A relationship between BaP in soll and tetrol metabolites in blood of mammals could not be established. Preliminary studies had shown that $\mathrm{BaP}$ was present in the soll at EFPC at concentrations up to 2.8 ug/g (Hoffman et al. 1984); however, the present study showed that BaP concentrations at EFPC during 1986 were considerably lower. Subchronic feeding studies with mice demonstrate that after a period of several weeks, BaP tetrol I-I is present in blood at low concentrations compared to concentrations reported following acute exposures and compared to concentrations found in this study during the first three weeks after administration of BaP. The metabolite was present at similar low concentrations in several species having close contact with the soll at the contaminated site. Whether these low levels were due to the same mechanism(s) as in the laboratory study or whether BaP exposure to $70 \mathrm{ng} / \mathrm{g}$ soil in the field was too low to result in adduct buildup over time is unknown. Additional studies at sites contaminated with other genotoxic chemicals are needed in order to further clarify the validity of using hemoglobin adducts as bioindicators of contaminant exposure in the field. 
Mercury

Mercury burdens in terrestrial mammals are related to diet and are lower in herbivores than in carnivores (National Research Council 1978). According to Wren (1986a) mercury concentrations are biomagnified within terrestrial food chains and highest levels of mercury (up to $40 \mathrm{ug} / \mathrm{g}$ wet weight of tissue) have been found in mammalian predators in areas where mercury-containing fungicides were widely used as seed disinfectants. Mercury does not appear to be concentrated in plants; levels are usually less than $0.5 \mathrm{ug} / \mathrm{g}$ fresh weight in reference areas and up to $3.5 \mathrm{ug} / \mathrm{g}$ over cinnebar deposits (Shacklette 1970).

Releases of mercury into EFPC have heavily contaminated the creek and its floodplain. Concentrations in the floodplain as high as 2,100 $\mu \mathrm{g} / \mathrm{g}$ of soil have been measured (Gist 1985). Total mercury has also been measured in vegetables grown along EFPC. Concentrations ranged from $0.00058 \mathrm{ug} / \mathrm{g}$ to $0.31 \mathrm{ug} / \mathrm{g}$ with an average value of $0.05 \mathrm{ug} / \mathrm{g}$ (Bashor and Turri 1986).

Although mercury was not previously documented to be present in WOC, this study shows that it is present on the wOC floodplain. Mercury may have been released into WOC from the ORNL plant and/or from burial grounds used for nonradioactive waste (Boyle et al. 1982). Concentrations on the floodplain ranged from $0.8 \mathrm{ug} / \mathrm{g}$ dry weight of soil at a site where there is little flooding to $7.0 \mathrm{ug} / \mathrm{g}$ dry weight of soil at a site where the floodplain is low and wet.

The natural trace metal content of soils varies depending on the rocks from which the soil was formed and weathering conditions; for solls in general, the mercury content averages $0.3 \mathrm{ug} / \mathrm{g}$ (Lisk 1972). 
The Hg concentration at SWSA-4, the contaminated reference site for mercury, averaged $0.2 \mathrm{ug} / \mathrm{g}$ dry weight.

In the present study, highest concentrations of mercury were found in $\underline{B}$. brevicauda at EFPC. The shorttail shrew is primarily insectivorous with a diet of earthworms, insects, and occasionally mice and voles. Its position in the food chain and its food habits, particularly the eating of soil-containing earthworms, make it ulnerable to the accumulation of mercury. Peromyscus leucopus, a seed eater, and $\underline{S}$. hispidus, an herbivore, had much lower burdens of mercury in kidney tissue. Mercury concentrations in kidney tissue of species collected along White Oak Creek (WCK) were not elevated above reference values, indicating no accumulation at soil concentrations of $\leq 7 \mathrm{ug} / \mathrm{g}$ of soil. No shrews were caught along this stream. Mercury concentrations in kidneys of all species trapped at the SWSA-4 reference site averaged less than the $3.9 \mathrm{ug} / \mathrm{g}$ indicative of environmental contamination according to Eisler (1987), but exceeded the 0.7 ug/g limit established for all tissues (National Research Council 1978). Mercury concentrations in kidney usually average higher than that of other tissues which may be the basis for the cited differences in $\mathrm{Hg}$ concentrations that are indicative of contaminated animals. The $\mathrm{Hg}$ concentration of 0.2 $u g / g$ in kidney of mice raised in the laboratory did not vary and was lower than the published background value of $0.7 \mathrm{ug} / \mathrm{g}$ (National Research Council 1.978). No information was located concerning toxic levels of inorganic mercury in tissues.

In the on $!^{\prime}$ other study that analyzed mercury in several environmental compartments, mercury was accumulated by two species of voles 
(Beardsley et a1. 1978), However, the mercury from the chlor-alkall plant was deposited on vegetation $(4 \mathrm{ug} / \mathrm{g})$, the primary food for voles. Concentrations in tissues were very $10 \mathrm{w}, 0.35$ and $0.5 \mathrm{ug} / \mathrm{g}$ in $\mathrm{kidney}$ tissue, compared to concentrations of up to $281 \mathrm{ug} / \mathrm{g}$ in kidney tissue of animals from EFPC.

\section{Strontium-90}

The bathtub effect at the southwestern corner of SWSA-4 appears to have contributed to contamination of the area. Soll concentrations of strontium-90 ranged from 44 to $150 \mathrm{~Bq} / \mathrm{g}$ dry weight (1,000 to 4,000 $\mathrm{pCi} / \mathrm{g}$ ) (Melroy et al. 1986) and fesque, the dominant vegetation at the site, averaged $37 \mathrm{~Bq} / \mathrm{g}(1,000 \mathrm{pCi} / \mathrm{g})$ dry weight (Garten and Lomax 1987). No previous studies reporting strontium-90 in soil and vegetation along wOC were found. Strontium-90 in floodplain soil at two sites along the reference area (EFPC), one above and one below the present trapping area, averaged less than $0.008 \mathrm{~Bq} / \mathrm{g}$ of soil (Hoffman et a1. 1984).

Small mammals accumulate strontium-90, a bone-seeking radionuclide, through dietary intake (Klusek 1987). At SWSA-4 highest levels of accumulation were present in bone tissue of $\underline{P}$. humulis. Eastern harvest mice feed mainly on seeds, living and eating in the strontium-90 contaminated fesque grass; four of the five individuals were collected in the grass immediately adjacent to the seeps. Strontium-90 concentrations were high in some individuals of all species caught at this site, but there was great intraspecies variation, probably reflecting the degree of overlap of the home ranges of the animals with the small seep area, which is less than $200 \mathrm{~m}^{2}$. 
Peromyscus leucopus was the most common species caught along WOC, but Strontium-90 accumulation was low. Of the three $\mathbf{S}$. hispldus which were caught within a few meters of each other adjacent to the creek (WCK 3.4), two showed bioaccumulation in bone (14.5 and $44 \mathrm{~Bq} / \mathrm{g}$ ), whereas the other had a much lower residue $(3.6 \mathrm{~Bq} / \mathrm{g})$. The only $\underline{\mathrm{P}}$. leucopus caught at this site was trapped about $50 \mathrm{~m}$ from the creek and had a very low concentration $(0.6 \mathrm{~Bq} / \mathrm{g})$. At EFPC, values for the $\mathrm{six}$ P. Leucopus and the three shitews averaged the same as the background count (1.2 counts/minute). Arthur et al. (1987) studied uptake of radionuclides at a waste site, but studied only one specles and only one tissue (lung) in addition to the carcass and pelt. Kaye and Dunaway (1962) trapped two species, but measured cesium-137, cobalt-60, and strontium-90 in carcass only.

Sentinel Species

The species of small mammals trapped in the ORNL area showed differences in their suitability as monitors of $\mathrm{BaP}, \mathrm{Hg}$, and Strontium90 and these differences may be due to disparate food habits (Table

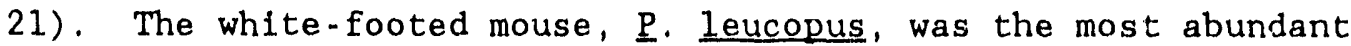
species at all sites, but was not the most suitable monitor of all three contaminants. Because of its opportunistic use of local habitats and its wide distribution, occurring from Canada south through the east and central U. S, to southern Mexico, it would make an ideal sentinel organism. Closely related species are found throughout the United States. McBee (1985) and Tice et al. (1987) have demonstrated the potential usefulness of this species as a monitor of genotoxic damage from environmental contaminants. They found evidence of alterations in 
Table 21. Evaluation of three small mammal species as biomonitors of benzo[a]pyrene, mercury, and strontium-90 at the ORNL site.

\begin{tabular}{|c|c|c|c|}
\hline \multirow[b]{2}{*}{$\begin{array}{c}\text { Trophic Leve1/ } \\
\text { Species }\end{array}$} & \multicolumn{3}{|c|}{ Relative Value as Sentinel Speciesa } \\
\hline & $\mathrm{BaP}$ & Mercury & Strontium-90 \\
\hline $\begin{array}{l}\text { Insectivore } \\
\text { Blarina brevicauda }\end{array}$ & $+1-$ & tt & + \\
\hline Omnivore & 8 & r & \\
\hline 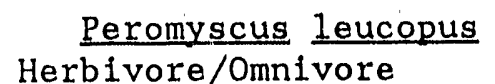 & - & + & + \\
\hline Sigmodon hisfidus & - & - & + \\
\hline
\end{tabular}
data)

${ }^{a}$ Key: ++ (excellent), + (good), " ("satisfactory or inadequate

the frequency of micronucleated erythrocyte and proliferating ce11s and chromosomal aberrations in $\underline{P}$. leucopus populations irihabiting hazardous waste sites containing complex mixtures of chemicals. Specific chemicals at the waste sites were not defined.

In the present study, however, $\underline{\underline{P}}$. leucopus was not a good monitor of the potentially genotoxic chemical, BaP, nor was it the best bioaccumulator of the heavy metal, mercury. BaP adducts to hemoglobin were not present in any of the 27 P. leucopus caught at EFPC or at the reference site. The mean mercury concentration in kidney tissue of animals from this site $(4.2 \mathrm{ug} / \mathrm{g})$ was above the $3.9 \mathrm{ug} / \mathrm{g}(1.1 \mathrm{ug} / \mathrm{g}$ fresh weight) level considered by Eisler (1987) as evidence of an environmental mercury problem; the difference was significant at thi $\mathrm{P}<0.01$ level. However, 16 of the 27 P. leucopus from EFPC analyzed had mercury concentrations below $3.9 \mathrm{ug} / \mathrm{g}$ (APPENDIX B). Lack of uptake compared to Blarina brevicauda was probably due to the above ground habits of this species and the abundant vegetation (shown to be low in 
inercury) which serves as the major food source. Minimal contact with the soll through habitat or eating habits restricts the intake of these soli-associated contaminants by $\underline{\underline{p}}$. leucopus. These data suggest that P. Leucopus, which is primarily a granivore and lives above ground, may not be suitable for biomonitoring of polycyclic aromatic hydrocarbons and is a questionable monitor for mercury.

Peromyscus leucopus was a good monitor of strontium-90 contamination at all sites, showing a graded response to the range of soil contamination (Table 20). The mean concentration of strontium-90 was higher at the heavily contaminated SWSA-4 seepage area and lower at the less contaminated WCK sites. At SWSA-4 the range of values probably reflected horne range overlap with the contaminated area. From this study, a concentration of $1.6 \mathrm{~Bq} / \mathrm{g}$ of bone (dry weight) can be considered evidence of soil contamination.

Earlier studies (Dunaway and Kaye 1961, Kaye and Dunaway 1963) reported cobalt-60 and ruthentum-106 in small mammals captured on the drained WOL bed. Since that time, seepage of strontium-90 from burial sites and migration into WCK and WOL has occurred. Results of the present study indicate that active areas of leakage from the burial. sites can be pinpointed using resident wildlife populations with small home ranges.

The data indicate that shrews are the most useful indicator species for monitoring a variety of pollutants. Blarina brevicauda was the second most abundant specius captured at the sites and was the only small mamnalian specias to show evidence of BaP exposure. All shorttail shrews captured at SWSA-4 had elevated concentrations of stron- 
tium-90 in bone tissue and all shrews captured at EFPC had higher levels of mercury than any other species captured. With the exception of one shrew, the concentration of mercury in kidney tissue was $\geq 15$ ug/g (APPENDIX B). This concentration can be considered evidence of a highly contaminated site and the species can be considered an excellent monitor. With a mean bone concentration of $23.5 \mathrm{Bg} / \mathrm{g}$ of strontium-90, Blarina brevicauda can be considered a good monitor of this radionuclide. None of the three species listed in Table 21 was considered an excelient monitor of strontium-90 because of the high standard deviations of the mean values.

Very few biomonitoring studies report contaminant concertrations in shrews. Most studies focus on larger, more economically important species. A few studies report on heavy metal concentrations in mammals (Wren 1986b), but only one (Smith and Rongstad 1982) reported mercury in shrews. Yet the shrew family (Soricidae) is distributed throughout the United States and Canada (Burt 1976) and all species consume ground-dwelling invertebrates and sometimes vertebrates as part of their diets. Their wide distribution, soil burrowing habits, and insectivorous to carnivorous eating habits make them potentially excellent sentinel species for a variety of contaminants. Drawbacks to using shrews as sentinel animals include difficulty in trapping compared to mouse species and alscontinuous distribution due to habitat requirements.

In the present study $\underline{\mathrm{S}}$. hispidus was not abundant enough at the EFPC site to determine contaminant uptake. It was present at SWSA-4 and WOC where it was a good monitor of strontium-90 (19.3 Bq/g at WCK 
and $59.5 \mathrm{~Bq} / \mathrm{g}$ at SWSA-4). A distribution limited to the southeastern United States, a habitat of grass-dominated areas, and a diet of nrimarily grass limit the usefulness of this species as a monitor of environmental contaminetion.

Other species were not trapped in large enough numbers to make meaningful comparisons concerning monitoring suitability. In addition to the shrew, only the Norway rat ( $\underline{R}$. norvegicus) and the muskrat ( $\underline{0}$. zibethica) showed traces of BaP tetrol I-1. All species at SWSA-4 showed uptake of strontium-90; thus uptake of this contaminant does not appear to be limited by food habits of the resident species because equally high concentrations of Strontium-90 occurred in both herbivores and insectivores.

General Considerations

Biological monitoring of contaminants is necessary to evaluate the movement of chemicals through food chains. There are important limitations to the use of small mammals for monitoring. Some of the contaminated study sites, such as SWSA-4, were very small in area (the most highly contaminated surface plume measured onl 8 by $24 \mathrm{~m}$ ), thus limiting the population sizes at these sites. More intensive trapping would have resulted in capture of recent immigrants.

Additional limitations to biological monitoring follow. Not all

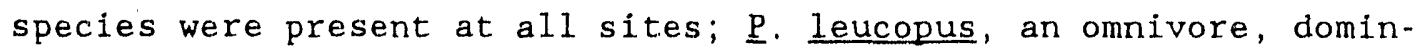
ated at most sites. There was extremely high variability of endpoints, probably reflecting the extent of overlap of home range of individuals with the contaminated area. However, since home ranges of most of the 
animals were small, one to one and one-half acres, contaminated areas could be closely pinpointed. Not all species were good sentinels. Insectivores in general, as exemplified by the shrew, were better biomonitors than herbivores. However, if the contaminant was taken up by vegetation, as in the case of strontium-90, then herbivores could be used. The sentiriel also must be compatible with the type of habitat in the contaminated zone. The eastern harvest mouse lived in the grassy area surrounding the radloactive seeps; no other species were liaptured in the grass. However, since the contamination had migrated via leaching or run off into a wooded area and down an adjacent bank, other species were exposed.

Despite the above limitations, biological availability of the three contaminants can be inferred from this study and if cleanup is being considered, a rationale can be provided for prioritizing sites. 
IV. CONCLUSIONS

A review of terrestrial biomonitoring studies using small mammals as indicator species provided information on the presence and bioavailability of several types of contaminants at nine sites, roadside sites, industrial areas, hazardous and radioactive waste disposal sites, and agricultural and forested 1and. Each species was evaluated for suitability as a monitor for specific contaminants. There was a positive relationship between biomonitoring capacity and trophic level. Insectivores were the best monitors of most contaminants, followed by omnivores and herbivores. For most contaminants there were one or two specific target tissues, but many studies did not monitor the best target tissue, analyzing on a whole body basis instead. In areas where a complex mixture of unidentified chemicals was present, several types of genotoxic and cytotoxic analyses were applied. Information was sparse for many contaminants.

In order to fill in some gaps in information and to test the hypothesis on trophic levels developed in the first part of the study, a variety of small mammals were trapped in the vicinity of the ORNL reservation in areas contaminated with BaP, mercury, and strontium-90. Formation of hemoglobin adducts with BaP was used as an indicator of BaP exposure. Mercury in kidney tissue and strontium-90 in bone tissue were determined by residue analyses. Contaminant levels in soil and vegetation were either determined experimentally or obtained from field studies by others.

Peromyscus leucopus, the white-footed mouse, was the most abundant species at all sites. Blarina brevicauda, the shorttail shrew, was the 
second most abundant species. Less common were $\underline{\mathbf{s}}$. hispidus, the cotton rat; Microtus sp., voles; and several other species.

Results of blood and tissue analyses showed site and species differences in exposure to the contaminants. Uptake was related to habitat and food preferences. Peromyscus leucopus, because of its abundance and wide distribution is the most useful species for monitoring sites where radionuclides are present; however, this specirs in not well suited as a biomonitor of polycyclic aromatic hydrocarbons such as BaP or heavy metals such as mercury. Blarina brevicauda is not as abundant or as widely distributed as $\underline{P}$. leucopus, but its trophic position makes it an ideal sentinel for a variety of contaminants. This species was the only one to show evidence of exposure to all three contaminants. Mercury concentrations in kidney tissus were more than an order of magnitude greater than those of other species and were related to the soil-associated habitat and feeding habits of this species. Elevated concentrations of stror ium-90 were present in the bone of all species trapped at the contam nated (SWSA-4) site. Strontium-90 was present in the vegetation at this site whereas mercury and BaP were associated with the soil only.

This study indicated that the quantification of hemoglobin adducts does not appear to be a feasible method to determine BaP exposure of small mammals collected at field sites. Analysis of blood following subchronic feeding studies with mice in the laboratory and following collection of small mammals in industrially-polluted areas showed low and erratic levels of a BaP metabolite-hemoglobin adduct. 


\section{LITERATURE CITED}

Anderson, T. J., G. W. Barrett, C. S. Clark, V. J. Elia, and V. A. Majet1. 1982. Metal concentrations in tissues of meadow voles from sewage sludge-treated flelds. J. Environ. Qual. 11:272277 .

Andrews, S. M., M. S. Johnson, and J. A. Cooke. 1984. Cadmium in small mammals from grassland established on metalliferous mine waste. Environ. Pollut. 33:153-162.

Anthony, B.. G. and R. Kozlowski. 1982. Heavy metals in tissues of small mammals inhabiting waste-water-irrigated habitats. J. Environ. Qual. 11:20-22.

Arthur, W. J., O. D. Markham, C. R. Groves, and B. L. Keller. 1987. Radionuclide export by deer mice at a solid radioactive waste disposal area in southeastern Idaho. Health Physics 52:45-53.

Bashor, B. S. and P. A. Turri. 1986. A method for determining an allowable concentration of mercury in soil. Arch. Environ. Contam. Toxicol. 15:435-438.

Beardsley, A., M. J. Vagg, P. H. T. Beckett, and B. F. Sansom. 1978. Use of the field vole ( $\underline{M}$. agrestis) for monitoring potentially harmful elements in the environment. Environ. Pollut. 16:65-71.

Bevenue, A., J. N. Ogata. L. S. Tengan, and J. W. Hylin. 1975. Mirex residues in wildlife and soils, Hawailan pineapple-growing areas - 1972-74. Pestic. Monit. J. 9:141-149.

Boyle, J. W., R. Blumberg, S. J. Cotter, et al. 1982. Environmental analysis of the operation of Oak Ridge National Laboratory (X-10 Site). ORNL-5870. Oak Ridge National Laboratory, Oak Ridge, TN.

Brown, K. W. and K. C. Donnelly. 1982. Mutagenic potential of water concentrates from the effluent of a waste oil storage pond. Bu11. Environ. Contam. Toxicol. 28:424-429.

Brown, L. N. 1964. Ecology of three species of Peromyscus from southern Missouri. J. Mamma1. 45:189-202.

Bull, K. R., R. D. Roberts, M. J. Inskip, and G. T. Goodman. 1977. Mercury concentrations in soil, grass, earthworms and sma11 mammals near an industrial emission source. Environ. Pollut. $12: 135-140$.

Burt, W. H. 1976. A Field Guide to the Mammals. 3rd edition. Houghton Mifflin Company, Boston, MA. 
Calleman, C.J. 1984. Hemoglobin as a dose monitor and 1ts appli.. cation to the risk estimation of ethylene oxide. ISBN 91.71462520x. Thesis, Department of Radiobiology, University of: stockholin, Sweden.

Cameron, G. N. and S. R. Spencer. 1981. Sigmodon hispldus Mamulian Species No. 158. Aner. Soc. Mammalog., pp 1.9.

Chuie1, K. M. and R. M. Harrison. 1981. Lead content: of small mamials at a roadside site in relation to the pathways of: exposure. Scj. Total. Environ. 1\%:145-154.

Clark, D. R. 1979. Lead concentrations: bats vs terrestrial smal1. mammals collected near a major highway. Environ. Scl. 'Technol. $13: 338-340$.

Cockerham, L. G, and A. L. Young. 1981. U1trastructural comparison of liver tissues from field and laboratory TCDD-exposed beach mice. In: R. E. Tucker et al., eds., Human and Environmental. Risks of Chlorinated Dioxins and Related Compounds. Plenum Press, New York, NY, pp. 373-389.

Dimond, J. B. and J.A. Sherburne. 1969. Persistence of DDT in wild populations of smal1 mamma1s. Nature 221:486-487.

Duraway, P. B. and S. V. Kaye. 1961. Studies of small mamma1 populations on the radioactive White Oak lake bed. In: J. B. Treferthen, ed., Transactions of the 26th North American Wild1fe and Natural. Resources Conference. Wildlife Management: Institute, Washington, DC, pp. 167-185.

Dunaway, P. B., J. D. Story, and J. T. Kitchings. 1971. Radiation effects and radionuclide excretion in a natural population of pine voles. In: Proceedings of the Third National. Symposium on Radioecology, volume 2. National Technical Information Service, Springfield, VA, pp. 1055-1064.

Dunn, B. P. 1981. Binding of orally administered benzo(a)pyrene to the DNA of mice over a dosage range if 100,000. In: Cooke, M. et a1., eds.. Polynuclear Aromatic Hydxocarbons: Physical and Biological Chemistry. Battelle Press, Columbus, OH, pp. 247 . 254.

Edwards, N. 'T', 1983. Polycycito aromatis hydrocarbors (PAHe) in the terrestrial ervirorment - a review. J. Environ. Quad. 12:427. 441.

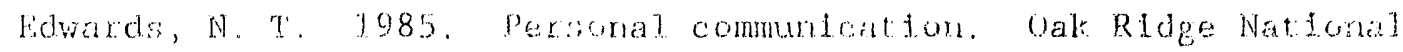
Latoratow, Oak RJge. TH. 
Eisler, R. 1987. Mercury hazards to fish, wildilfe, and Invertebrates: a synoptic review. Blological Report 85(1.10). U. S. Fish and Wildife Service, Patuxent Wildlife Research Center, Laure1, MD.

Elfving, D. C., W. M. Haschek, R. A. Stehn, C. A. Bache, and D. J. Lisk. 1978. Heavy metal residues in plants cultivated on and in small mammals indigenous to old orchard solls. Arch.

Environ. Health, March/April.

Evans, D. M. 1973. Seasonal variations in the body composition and nutrition of the vole, Microtus agrestis. J. Anim. Eco1. 42:118.

Fanell1, R., M. P. Bertoni, M. G. Castelli, C. Chiabrando, G. P. Martelli, A. Noseda, S. Garattini, C. Binaghi, V. Marazza, and F. Pezza. 1980a. 2,3,7,8-Tetrachlorodibenzo-p-dioxin toxic effects and tissue levels in animals from the contaminated area of Sevesco, Italy. Arch. Environ. Contam. Toxicol. 9:569-577.

Fanel11, R., M. G. Castelli, G. P. Martelli, A. Noseda, and S. Garattini. 1980b. Presence of 2,3,7,8-tetrachlorodibenzo-pdioxin in wildlife living near Seveso, Italy: a preliminary study. Bull. Environ. Contam. Toxicol. 24:460-462.

Farmer, P. B., H. G. Neumann, and D. Henschler. 1987. Estimation of exposure of man to substances reecting covalently with macromolecules. Arch. Toxico1. 60:251-260.

Fimreite, N., R. W. Fyfe, and J, A. Keith. 1970. Mercury contamination of Canadian prairie seed eaters and their avian predators. Can. Field-Natural. 83:269-276.

Forsyth, D. J, and T. J. Peterle. 1984. Species and age differences in accumulation of $36 \mathrm{Cl}-\mathrm{DDT}$ by voles and shrews in the fleld. Environ. Pollut. 33:327-240.

Gardner, W. S., D. R. Kendall, R. R. Odum, H. L. Windom, and J. A. Stephens. 1978. The distribution of methyl mercury in a contaminated salt marsh ecosystem. Environ. Pollut. 15:243-251.

Garten, C. T., Jr., E. A. Bondietti, J. R. Trabalka, R. L. Walker, and T. G. Scott. 1987. Field studies on the terrestrial behavior of actinide elements in East Tennessee. In: Pinder, J. E., III, et al., eds., Environmental Research on Actinide Elements. CONF-841142. Office of Scientific and Technical Information, U. S. Department of Energy, pp. 109-119. 
Garten, C. T., Jr., and R. D. Lomax. 1987. Strontium-90 contamination in vegetation from radioactive waste seepage areas at ORNL, and theoretical calculations of ${ }^{90} \mathrm{Sr}$. accumulation by deer. ORNL/TM 10453. Oak Ridge National Laboratory, Oak Ridge, TN.

Gelboin, H., and P. O. P. 'T'so. 1978. Polycyclic Hydrocarbons and Cancer: Molecular Blology and Environment. Academic Press, New York, NY.

George, S. B., J. R. Choate, and H. H. Genoways. 1986. Blarina brevicauda. Mamalian Species No. 261. Amer. Soc. Mammalog., pp. $1-9$.

Getz, L. L., L. Verner, and M. Prather. 1977. Lead concentrations in sma11 mammals living near highways. Environ. Pollut. 13:151157.

Gist, C. 1985. Unpublished data. Oak Ridge Associated Universities, Oak Ridge, TN.

Goldsmith, C. D. and P. F. Scanlon. 1977. Lead levels in small mammals and selected invertebrates associated with highways of different traffic densities. Bul1. Environ. Contam. Toxicol. $17: 311-316$.

Goyer, R. A., D. L. Leonard, J. F. Moore, B. Rhyne, and M. R. Krigman. 1970. Lead dosage and the role of the intranuclear Inclusion body, an experimential study. Arch. Environ. Health $20: 705-711$.

Greichus Y. A. and B. A. Dohman. 1980. Polychlorinated biphenyl contamination of areas surrounding two transformer salvage companies, Colman, South Dakota - September 1977. Pestic. Monit. J. $14: 26-30$.

Griffin, G. D., B. Z. Egan, N. E. Lee, and C. A. Burtis. 1986. Induction of mixed-function oxidase activity in mouse lymphold tissues by polycyclic aromatic hydrocarbons. J. Toxicol. Environ. Health 19:185-194.

Haberer, K. 1965. Measurement of beta activities in aqueous samples utilizing Cerenkov radiation. Packard Technical Bulletin No. 16. Packard Instrument Company, Downers Grove, IL.

Halford, D. K. 1987. Density, movement, and transuranic tissue inventory of sma1l mammals at a liquid radioactive waste disposal area. In: Pinder, J. E., III, et al. eds., Environmental Research on Actinide Elements. CONF-841142. Office of Scientific and Techrical Information, U. S. Department of Energy, pp 147-156. 
Hal1, E. R. 198\%. The Mammals of North America, Volumes I \& II. John Wiley \& Sons, New York, NY.

Hammond, P. B. and R. P. Beliles. 1380. Chapter 17: Metals. In: J. Doull et al., eds., Casarett and Doull's Toxicology: the Basic Science of Poisons, 2nd ed. Macmillan Publishing Co., New York, NY, PP. 409-468.

Haschek, W. M., D. J. Lisk, and R. A. Stehn. 1979. Accumulation of lead in rodents from two old orchard sites in New York. In: Animals as Monitors of Environmental Pollutants. National Academy of Sciences, Washington, DC, pp. 192-199.

Hobbs, C.H. and R.O. McClellan. 1980. Chapter 19: Radiation and radioactive materials. In: J. Doull et al., eds., Casarett and Doull's Toxicology: the Basic Sclence of Poisons, 2nd ed. Macmillan Publishing Co., New York, NY, pp. 497-531.

Hoffman, F. O., B. G. Blaylock, C. C. Travis, et al. 1984. Preliminary screening of contaminants in sediments. ORNL/TM-9370. Oak Ridge National Laboratory, Oak Ridge, TN.

Hunter, B. A. and M. S. Johnson. 1982. Food chain relationships of copper and cadmium in contaminated grassland ecosystems. Oikos $38: 108-117$.

Jefferies, D. J. and M. C. French. 1972. Lead concentrations in small mammals trapped on roadside verges and field sites. Environ. nollut. 3:147-156.

Jefferies, D. J. and M. C. French. 1976. Mercury, cadmium, zinc, copper and organochlorine insecticide levels in small in rmmals trapped in a wheat fleld. Environ. Pollut. 10:175-182.

Jefferies, D. J., B. Stainsby, and M. C. French. 1973. The ecology of small mammals in arable fields drilled with winter wheat and the increase in their dieldrin and mercury residues. J. Zool. $171: 513-539$.

Jenkins, J. H., A. H. Davis, W. J. Bigler, and G. L. Hoff. 1980. Mercury and cesium-137 in urban gray squirrels. Bul1. Environ. Contam. Toxicol. 25:321-324.

Jett, D. A., J. D. Nichols, and J. E. Hines, 1986. Effect of Orthene on an unconfined population of the meadow vole (Microtus pennsylvanicus). Can. J. Zool. 64:243-250. 
J fmenez, B. D., G. H. Ezel1, Z. B. Lgan, N. L. Lee, J. J. Beuchanp, and J. F. McCarthy, 1985. Effects of leading and temperature on the mixed function oxldase (MF) systes ln bluegl11 sunfish, Lepomfs macrochirus. Meeting abstract. Sixth Amual Meting of the Soclety of Envtromental 'loxtcology and Chemistry held in St. Loufs, Missourt, November $10-13$, p. 76.

Johnson, M. S., R. D. Roberts, M. Hutton, and M. J. Jnsklp. 1.978. Distribution of lead, zinc aid cadmium in smald mamals from polluted environments. O1kos 30:153-159.

Kaye, S, V. and P. B. Dunaway, 1962. Bloaccumlation of radioactive isotopes by herbivorous small mamals. Hent th thysics 7:205. 217.

Kaye, S. V. and P. B. Dunaway, 1963. Estimation of dose rate and equilibrium state from bioaccumalation of radionuclides by mammals. In: V. Schultz and A. W. Klement, eds., Proceeding of the First National Symposium on Radioecology. Reinhold Publishing Co., New York, NY, pp. 107-111.

Kenda11, R. V. 1982. Wildlife toxicology. Environ. Sct. 'Technol. $16: 448 \mathrm{~A}-453 \mathrm{~A}$.

Kikkawa, J. 1964. Movement, activity and distribution of sma11. rodents Clethrionomys glareolus and Apodemus sylvaticus in woodland. J, Anim. Ecol. 33:259-2.99.

Kitchings, J. T. and D. J. Levy. 1981. Habltat patterns in a smal1 mamna1 community. J. Mamma1. $62: 814-820$.

Klusek, C. S. 1987. Stronthum 90 fn food and bone from fallout. J. Environ. Quality 16:195-199.

Koreeda, M., P. D. Moore, P. G. Wisiock1, W. Levin, A. H. Conney, H. Yagi, and D. M. Jerina, 1978. Binding of benzola]pyrene 7,8diol-9,10-epoxides to DNA, RNA and mouse skin occurs with high stereoselectivity. Sclence 199:778-781.

Lackey, J. R., D. G. Huckaby, and B. G. Ormiston. 1985. Peromyscus leucopus. Mamnalian Species lNo. 247. Mnex. Soc. Manmolog., pp. 1. -10 .

Larsen, I. L. 1981. Strontium-90 determinattons by Cerenkov radiation counting for wo l. monitorfng at Oak Ridge National Laboratory. ORNL/TM-7760. Oak RLdge National. Laboratory, Oak Ridge, TN.

Laubscher, J. A., G. R. Dutt, and C. C. Roan. 1.971. Chiorinated insecticide residues fil wilditfe and soll as a function of distance from application. Pestic. Monit. J. 5:251-258. 
Lincer, J, L. and J. A. Sherburne. 1974. Organochlorines in kestrel. prey: a north-south dichotomy, J. Wildl. Manage, 38:427-434.

Linzey, A. V. 1987. Effects of chronfic polychlorinated biphenyls exposure on reproductive success of white-footed mice (Peromys cus leucopus). Arch. Environ. Contam. Toxico1, 16:455-460.

Lisk, D. J. 1972. Trace metals in solls, plants, and animals. Adv. Agron, 24:267-325.

Lomenlck, T. F. and K. E. Cowser. 1961. Status report on evaluation of solid waste disposal at ORNL-II. National Laboratory, Oak Ridge, TN.

ORNL-3182. Oak Ridge

Ma, W. -C. 1987. Heavy metal accunulation in the mole, Talpa europea, and earthworms as an indicator of metal bloavaliability in terrestrial environments. Bull. Environ. Contam. Toxicol. $39: 933-938$.

McBee, K. 1985. Chromosomal aberrations in resident small mammals at a petrochemical waste dump site: A natural model for analysis of environmental mutagenesis. PhD Dissertation. Texas A\&M University, College Station, TX.

McBee, K. and J. W. Bickham. 1988. Petrochemical-related DNA damage in wild rodents detected by flow cytometry. Bull. Environ. Contam. Toxico1. 40:343-349.

McBee, K., J. W. Bickham, K. W. Brown, and K. C. Donnelly. 1987. Chromosomal aberrations in native small mammals (Peromyscus leucopus and Sigmodon hispidus) at a petrochemical waste disposal site: I. standard karyology. Arch. Environ. Contam. Toxicol.16: 681-688.

Means, J. C., S. G. Wood, J. J. Hassett, and W. L. Banwart. 1980. Sorption of polynuclear aromatic hydrocarbons by sediments and solis. Environ. Science \& Technol. 14:1524-1528.

Melroy, L. A., D. D. Huff, and N. D. Farrow. 1986. Characterization of the near-surface radionuclide contamination assoctated with the bathtub effect at solid waste storage area 4, Oak Ridge, National Laboratory, Tennessee. ORNL/TM-10043. Oak Ridge National Laboratory, Oak Ridge, TN.

Menzer, R. E. and J. O. Ne1son. 1980. Chapter 25: Water and soll pollutants. In: J. Doull et al,, eds., Casarett and Doull's Toxicology: the Basic Science of Poisons, 2nd ed. Macmillan Publishing Co., New York, NY, pp. 497-531.

Merritt, J. F. 1981. Clethricnomys gapper1. Mammalian Species No. 146. Amer. Soc. Mammalog, pp. 1-9. 
Mierau, G, W. and B, E. Favara, 1975. Lead polsoning, in ruadside populations of deer mice. Environ. Pollut. 8:55.54.

Mouw, L., K. Kalltis, M. Anver, J. Schwartz, A. Constan, R. Hartung, B. Cohen, and D. Ringler. 1975. Lead: possible toxiclty in urban vis rural rats. Arch. Environ. Health 30:276-280.

Munger, F, 1.988. Oak Ridge mercury findings promisting. Knoxville News-Sentine1. March 14, 1988.

Murphy, S, D. 1980, Chapter 16: Pesticides. In: J. Doull et al., eds., Casarett and Doul1's Toxicology, the Basic Sclence of Polsons. Macmillan Publishing Co., New York, NY, pp. 357-409.

Nationa1 Research Counc11. 1978. An assessment of mercury in the envirorunent. National Academy of Sclences, Washington, DC.

Nayak, B. N. and M. L. Petras, 1985. Environmental monftoring for genotoxicity: in vivo sister chromatid exchange in the house mouse (Mus musculus). Can. J. Cyto1. 27:351-356.

Nebert, D. W. and H, V. Gelboin. 1969. The in vivo and in vitro induction of aryl hydrocarbon hydroxylase in mammallan cells of different species, tissues, strains, and developmental and hormonal states. Arch, Biochem. Biciphysics 134:76-89.

Nowak, R. M. and J. L. Paradiso. 1983. Walker's Mammals of the World. 4th ed., Volunes I \& II. The Johns Hopkins University Press, Baltimore, MD.

Osterman-Golker, S., L. Ehrenberg, D. Segerback, and I. Halstrom. 1976. Evaluation of genetic risks of alkylating agents. II. Hemoglobin as a close monitor. Mutat. Res. 34:1-15.

Pernetta, J. C. 1976. Diets of the shrews Sorex araneus L. and Sorex minutus L. in Wytham grassland. J. Animal Ecol. 45:899912 .

Pollard, E. and J. Relton. 1970. A study of small mammals in hedges and cultivated fields. J. App1. Eco1. 7:549-557.

Quarles, H. D. III, R. B. Hanawalt, and N. E. Odum. 1974. Lead in small mammals, plants, and soll at yarying distances from a highway. J. App1, Eco1. 11:937-949,

Rakn, R., S. Chang, J. Holland, and L. Shugart. 1982. A fluorometric-HPLC assay for quantitating the binding of BaP metabolites to DNA. Biochem. Blophy. Res. Comn. 109:262-268. 
Rattner, B. A. and D. J. Hoffman. 1987. Monitoring contaminant exposure in wildlife with mixed-function oxygenases. Meeting abstract. Eighth Annual Meeting of the Soclety of Environmental Toxicology and Chemistry held In Pers'acola, Florida, November 9 12, p. 171 .

Relch, L. M. 1981. Microtus pennsylvanicus. Mammalian Species No. 159. Amer. Soc. Mammalog., pp. 1-8.

Roberts, R. D. and M. S. Johnson, 1978. Dispersal of heary metals from abandoned mine workings and the tr transference through terrestrial food chains. Environ. ?ollut. 16:293-310.

Roberts, R. D., M. S. Johnson, and M. Hutton. 1978. Lead contamination of small mammals from abandoned me,te, ilftarous mines. Environ. Pollut. 15:61-69.

Rowley, M. H., J. J. Christian, D. K. Basu, M. A. Pawlikowski, and B. Paigen. 1983. Use of small rnammals (voles) to assess a hazardous waste site at Love Canal, Nlagara Falls, New York. Arch. Environ. Contam. Toxicol. 12:383-397.

Rudge, M. R. 1968. The food of the common shrew Sorex araneus $L$. (Insectivora: Soricidae) In Britain. J. Animal Ecol. 37:565. 581.

Scanlon, P. F. 1979. Lead contamination of mammals and invertebrates near highways with different traffic volumes. In: Animals as Monitors of Environmental Pollutants. National Academy of Sciences, Washington, DC, pp. 200-208.

Schlesinger, W. H. and G. L. Potter. 1974. Lead, copper, and cadmium concentrations in small mammals in the Hubbard Brook Experiment Forest. O1kos 25:148-152.

Shacklette, H. T. 1970. Mercury content of plants. U. S. Geol. Surv. Prof. Pap. 713:35-35.

Sharma, R. P. and J. L. Shupe, 1977. Lead, cadmium, and arsenic residues in animal tissues in relation to those in their surrounding habitat. Sci. Total Environ. 7:53-62.

Shugart, L. 1985. Quantitating exposure to chemical carcinogens: in vivo alkylation of hemoglobin by benzo[a]pyrene. Toxicology $34: 211-220$.

Shugart, L., R. O. Rahn, and J. M. Holland. 1985. Quantifying benzo[a]pyrene binding to DNA by fluorescent analysis. In: $M$. W. Cooke and A. J. Dennis, eds., Polynuclear Aromatic Hydrocarbons: Seventh International Symposium on Formation, Metabolism and Measurement. Battelle Press, Columbus, OH, pp. 1087-1097. 
Sigma Chemical Company. 1982. The quantitative colorimetric determination of total hemoglobin in whole blood at 530-550 un. Technical Bulletin No. 525. Sigma Chemical Company, Saint Louis, MO.

Silkworth, J. B., D. N. McMartin, R. Rej, R. S. Narang, V. B. Stein, R. G. Briggs, and L. S. Kaminsky. 1984. Subchronic exposure of mice to Love Canal soil contaminants. Fund. App1. Toxicol. 4:231-239.

Silkworth, J. B., C. Tumasonis, R. G. Briggs, A. S. Narang, R. S. Narang, $R, \operatorname{Re} j, V$. Stein, D. N. McMartin, and L. S. Kaminsky. 1986. The effects of Love Canal soll extracts on maternal health and fetal development in rats. Fund. App1. Toxicol. $7: 471-485$.

Sims, P., P. L. Glover, A. Swaisland, K. Pal, and A. Hewer. 1974. Metaboifc activation of benzo[a]pyrene proceeds by a diol epoxide. Nature 252:326-328.

Spencer, S. R. and G. N. Cameron. 1982. Reithrodontomys fulvescens. Mammalian Species No. 174. Amer. Soc. Mammalog., pp. 1-7.

Smith, G. J. and O. J. Rongstad. 1982. Small mammal heavy metal concentrations from mined and control sites. Environ. Pollut. $28: 121-134$.

Smolen, M. J. 1981. Microtus pinetorum. Mammalian Species No. 147. Amer. Soc. Mammalog., pp. 1-7.

Stout. J. G. 1988. Unpublished data. Oak Ridge National Laboratory, Oak Ridge, TN.

Suess, M. J. 1976. The environmental load and cycle of polycyclic aromatic hydrocarbons. Sci. Total Environ. 6:239-250.

Terman, C. R. and R. J. Huggett. 1980. Occurrence of Kepone in white-footed mice (Peromyscus leucopus noveboracensis) on Jamestown Island, Virginia, Environ. Int1. 3:307-310.

Thalken, C. E. and A. L. Young. 1981. Long-term field studies of a rodent population continuously exposed to TCDD. In: R. E. Tucker et al., eds., Human and Environmental Risks of Chlorinated Dioxins and Related Compounds. Plenum Press, New York, NY, pp. $357-372$.

Tice, R. R., B. G. Ormiston, R. Bnucher, C. A. Luke, and D. E. Paquette. 1987. Enviroimental biomonitoring with feral rodent species. In: S. S. Sandhu et al., eds., Short-term Bloassays in the Analysis of Complex Mixtures. Plenum Press, New York, NY, pp. $175-180$. 
Turner, R, 1987. Personal communication. Oak Ridge National Laboratory, Oak Ridge, TN.

U. S. Environmental Protection Agency. 1982. Test methods for evaluating solid waste: Physical/chemical methods. SW-846. U. S. Environmental Protection Agency, Washington, DC.

Val Valin, C. C., A. H. Andrews, and L. K. Eller. 1968. Some effects of mirex on two warm water fishes. Trans. Amer. Fish. Soc. 97:185-198.

van den Brink, F. H. 1968. A Guide to the Mammals of Britain and Europe. Houghton Miffilin Company, Boston, MA.

Watson, M. R., W. B. Stone, J. C. Okoniewski, and L. M. Smith. 1985. Wildiffe as monitors of the movement of polychlorinated biphenyls and other organochlorine compounds from a hazardous waste site. Trans. Northeast. Fish and Wildlife Conf. held in Hartford, CT, May 5-8, pp. 91-104.

Watts, C. H. S. 1968. The foods eaten by wood mice and bank voles in Wytham Woods, Berks. J. Anim. Ecol. 37:25-41.

Way, C. A. and G. D. Schroder. 1982. Accumulation of lead and cadmium in wild populations of the commensal rat, Rattus norveglicus. Arch. Environ. Contam. Toxico1. 11:407-411.

Welch, W. R. and D. L. Dick. 1975. Lead concentrations in tissues of roadside mice. Environ. Pollut. 8:15-21.

Westlake, G. E., C. A. Blunden, P. M. Brown, P. J. Bunyan, A. D. Martin, P. E. Sayers, P. I. Stanley, and K. A. Tarrant. 1980. Residues and effects in mice after drilling wheat treated with chlorfenvinphos and an organomercurial fungicide. Ecotoxicol. Environ. Safety 4:1-16.

Westlake, G. E., P. J. Bunyan, J. A. Johnson, A. D. Martin, and P. I. Stanley. 1982. Biochemical effects in mice following exposure to wheat treated with chlorfenvinphos and carbophenothion under laboratory and field conditions. Pestic. Biochem. Physiol. $18: 49-56$.

Whitaker, J. O., Jr. 1974. Cryptotis parva. Mammalian Species No. 43. Amer. Soc. Mammalog., pp. 1-8.

Whitaker, J. O., Jr., and T. W. French. 1984. Foods of six sympatric shrews from New Brunswick. Can. J. Zool. 62:622-626.

Williamson, P. and P. R. Evans. 1972. Lead: levels in roadside invertebrates and small mammals. Bull. Environ. Contam. Toxicol. 8:280-288. 
Wolfe, J. L. and B. R. Norment. 1973. Accumulation of mirex residues in selected organisms after an aerial treatment, Mississippi - 1971-72. Pestic. Monit. J. 7:112-116.

Wren, C. D. 1986a. A review of metal accumulation and toxicity in wild mammals. 1. Mercury. Environ. Res. 40:210-244.

Wren, C. D. 1986b. Mammals as biological monitors of environmental metal levels. Environ. Monit. Assess. 6:127-144.

Zink1, J. G., R. B. Roberts, C. J. Henny, and D. J. Lenhart. 1980. Inhibition of brain cholinesterase activity in forest birds and squirrels exposed to aerially applied acephate. Bull. Environ. Contam. Toxicol. 24:676-683. 
APPENDICES

$131 / 132$ 


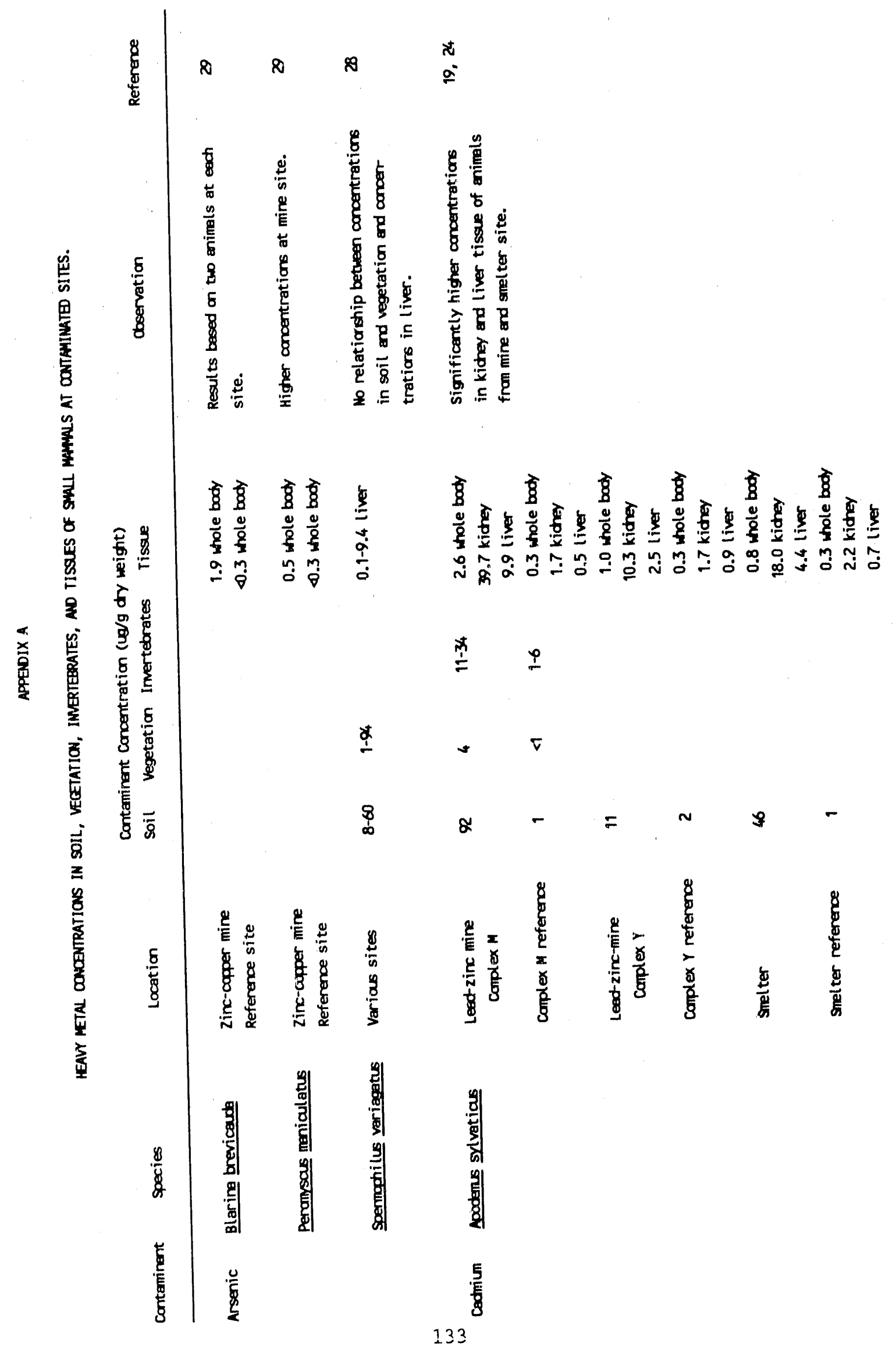




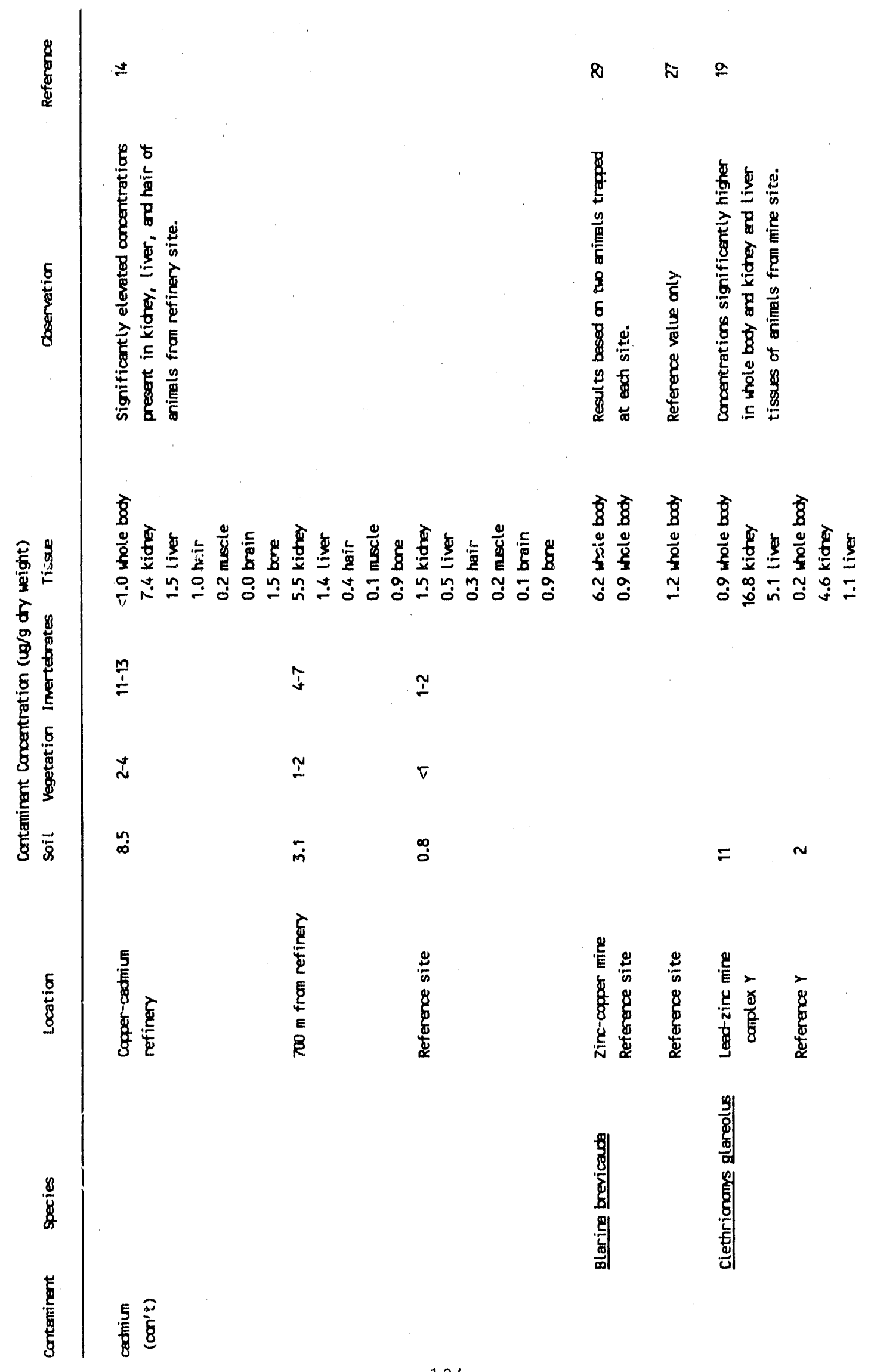




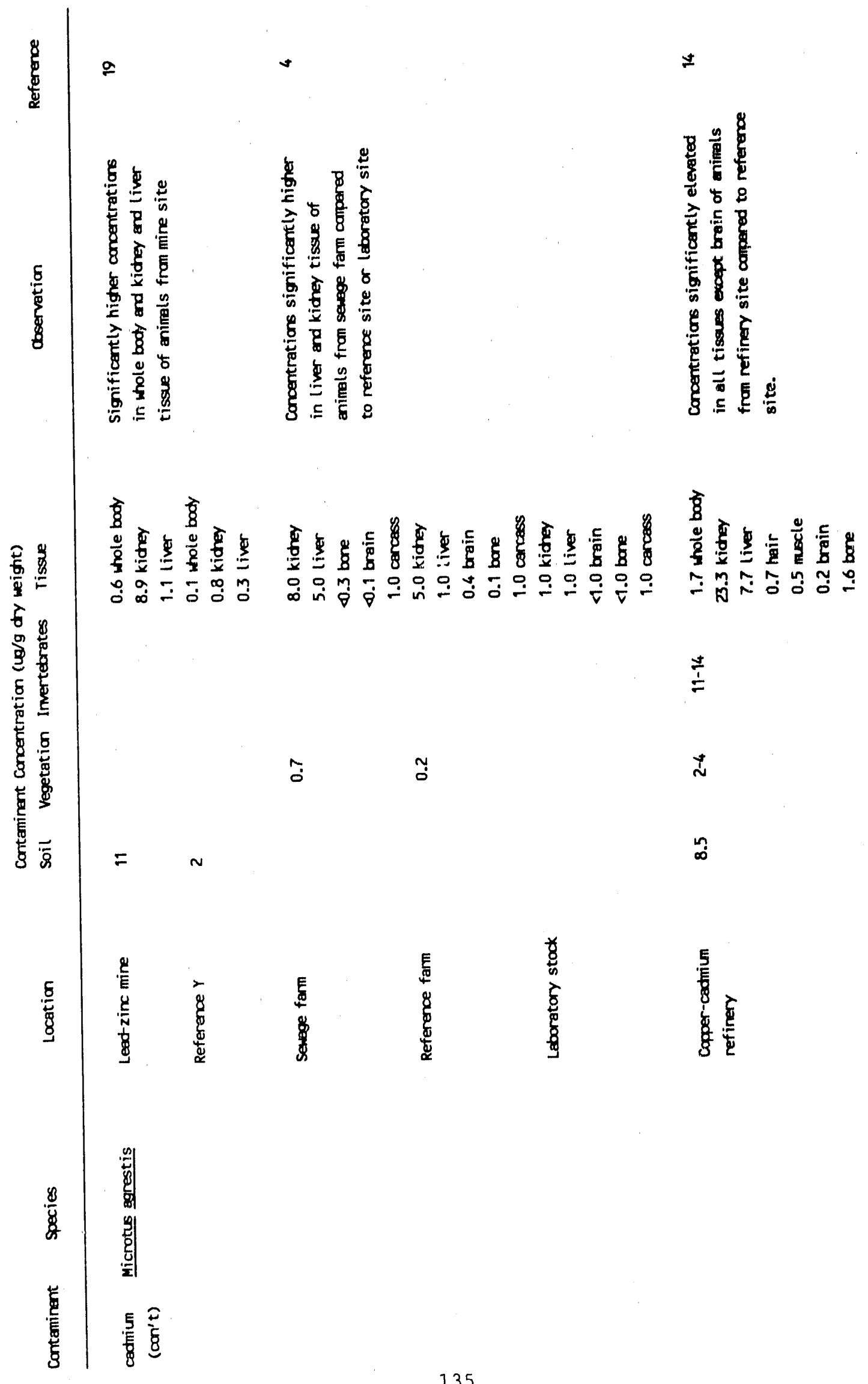




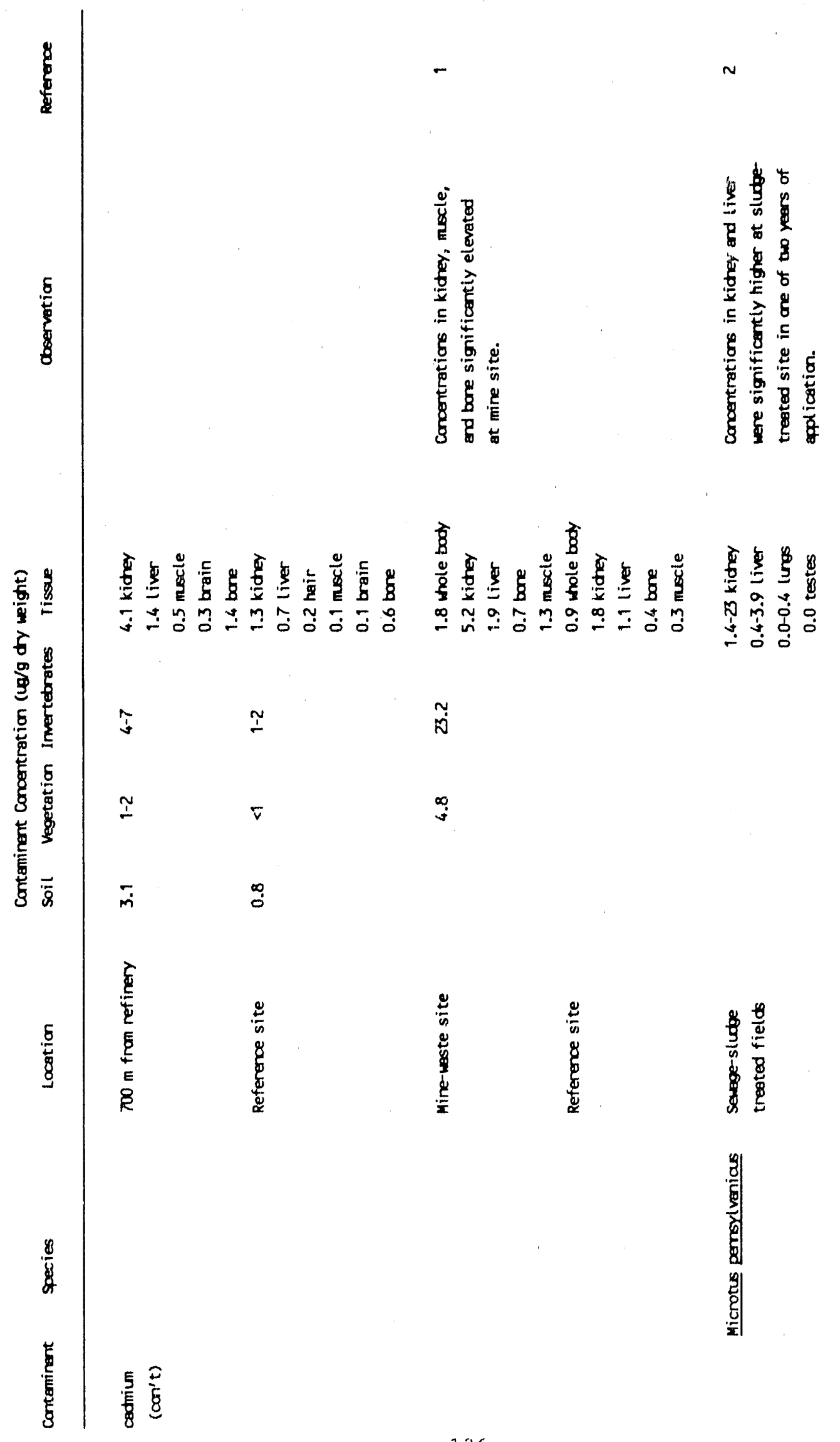




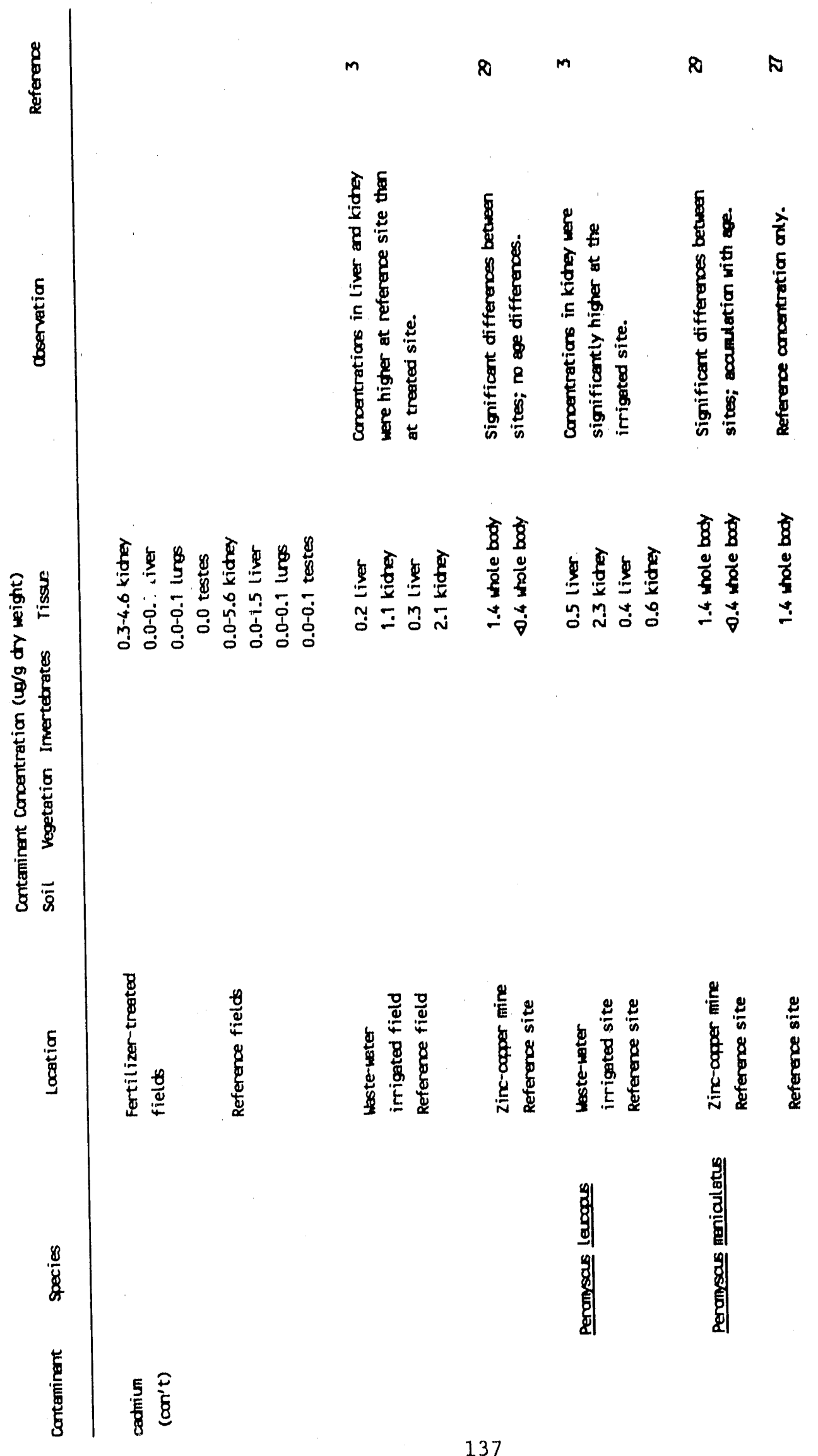




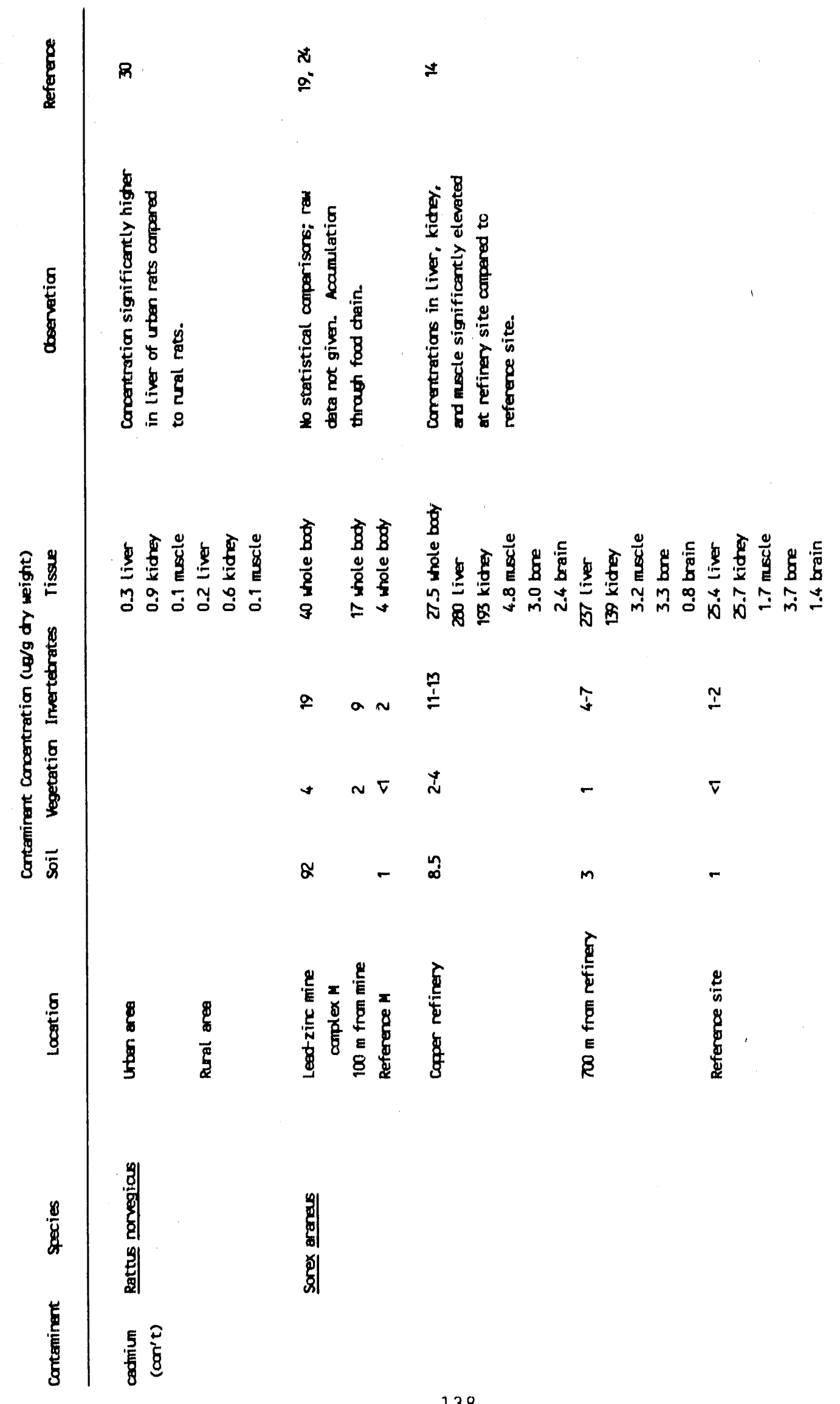




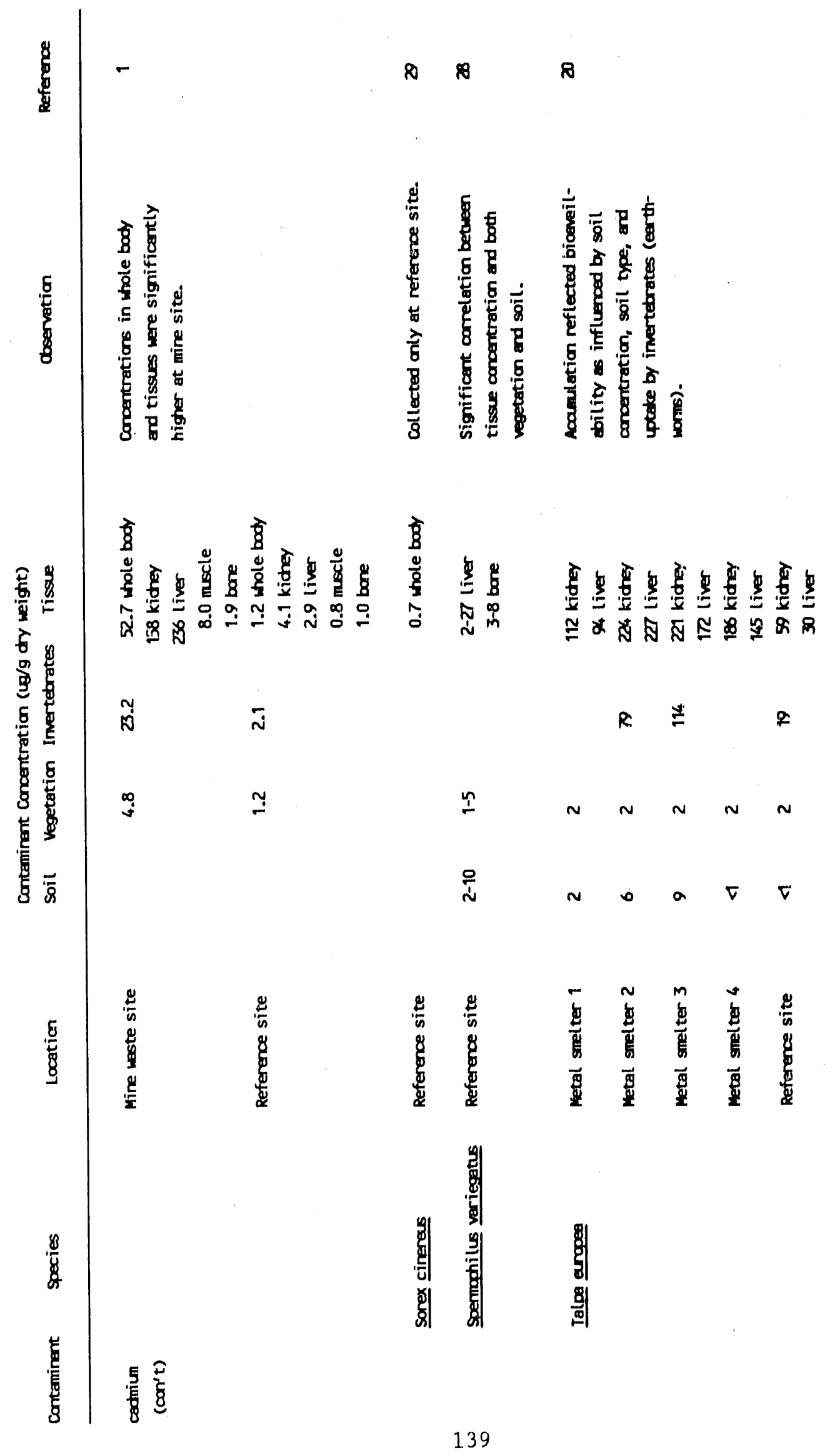




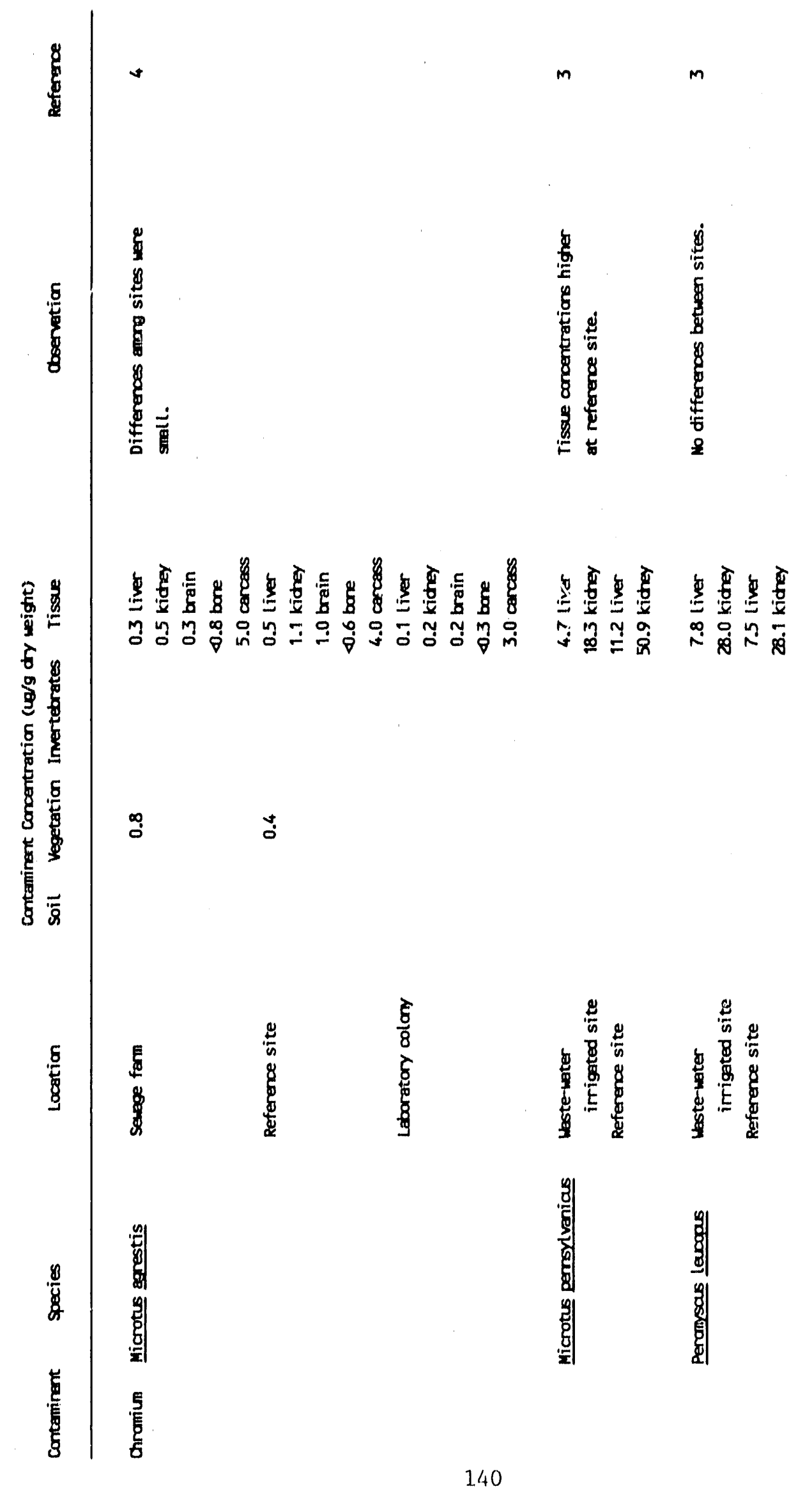




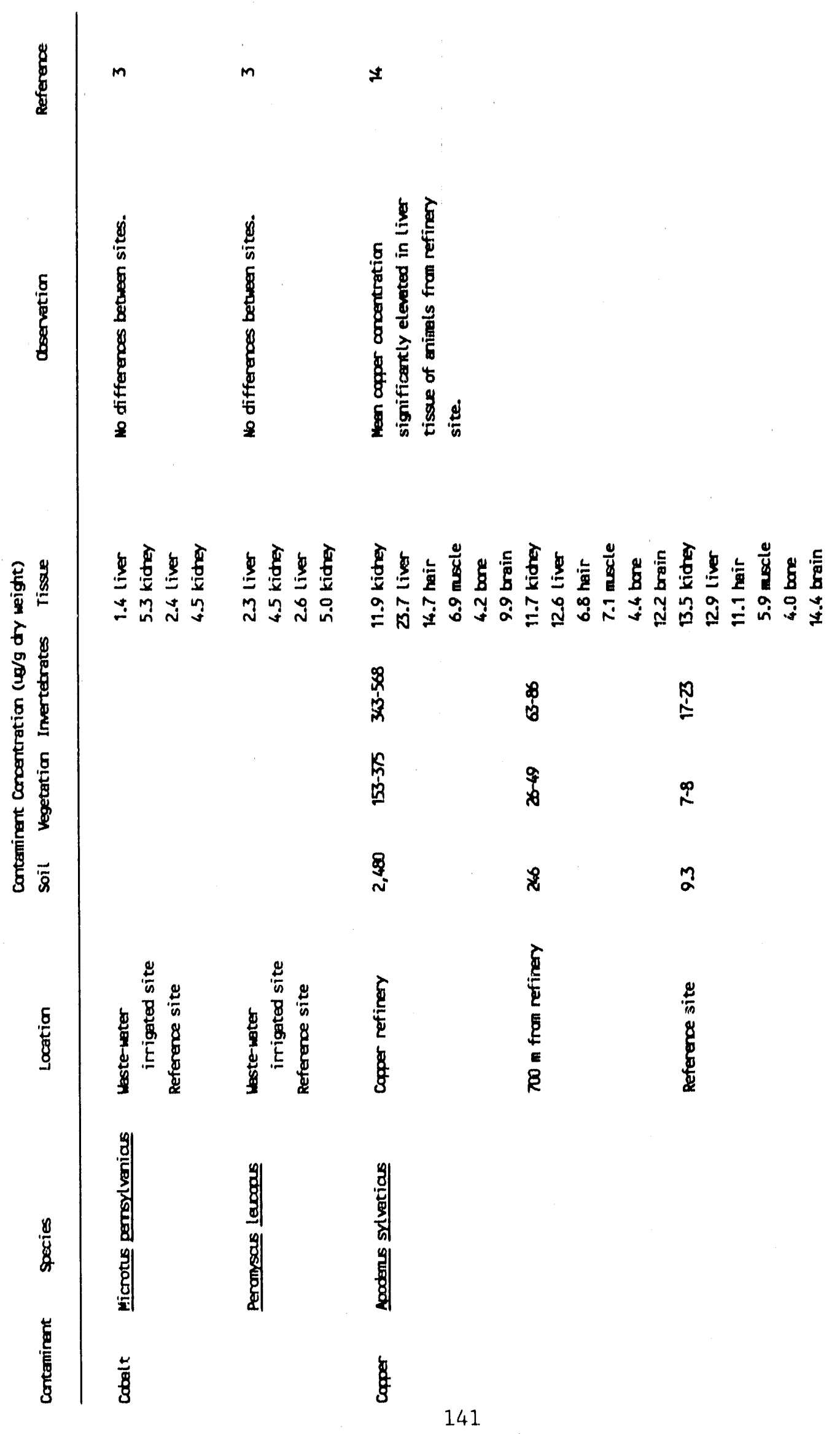




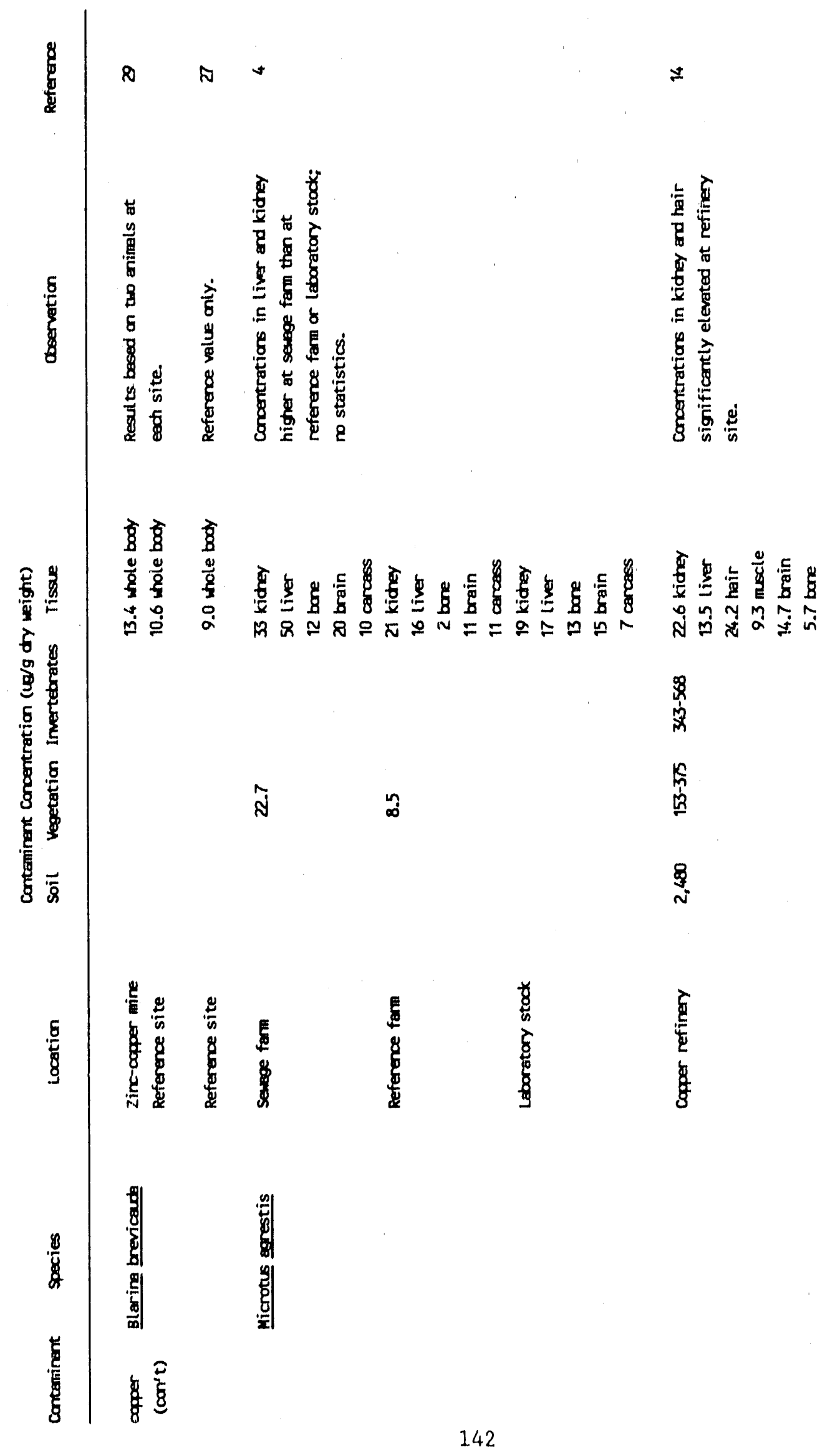




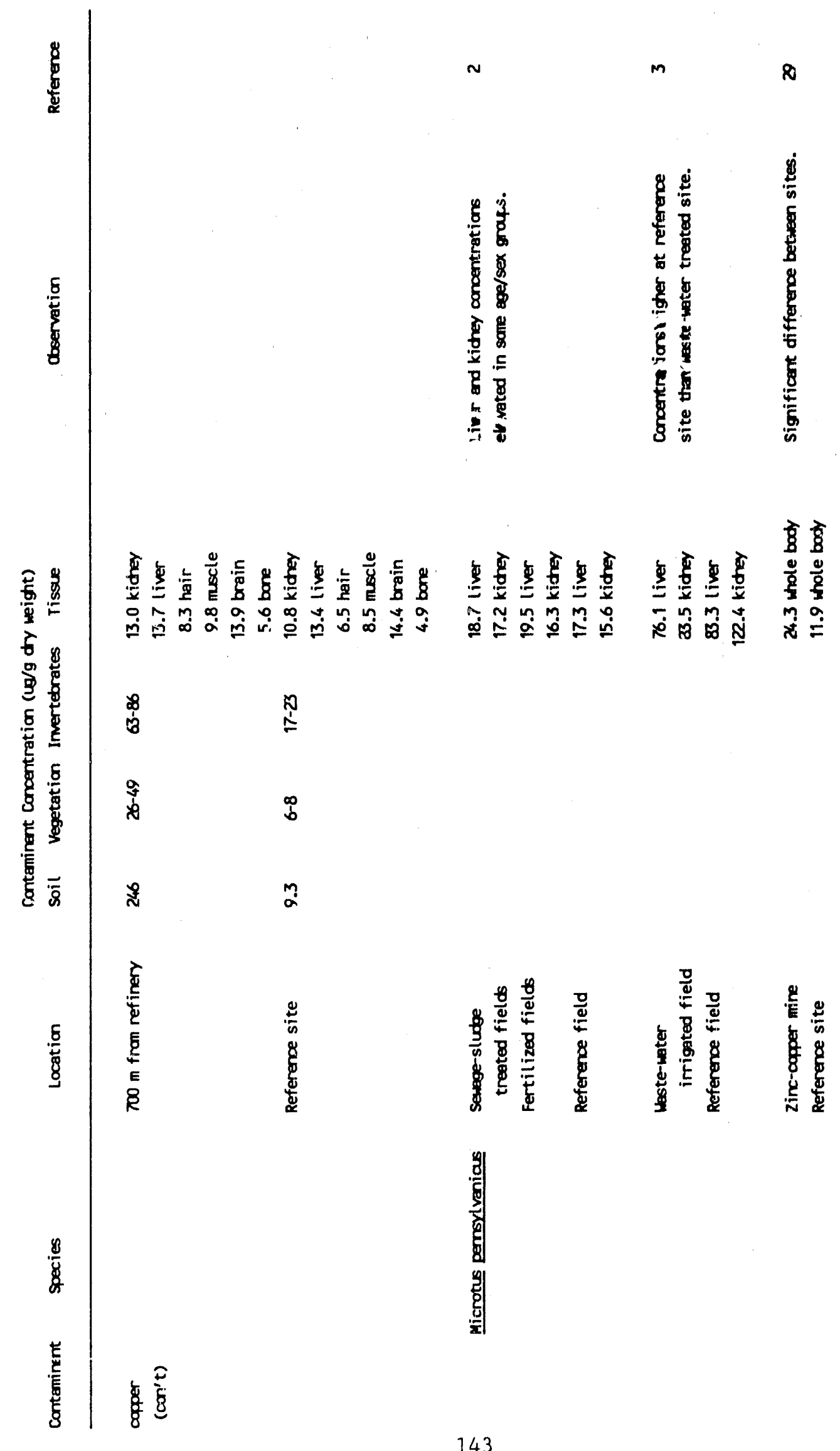




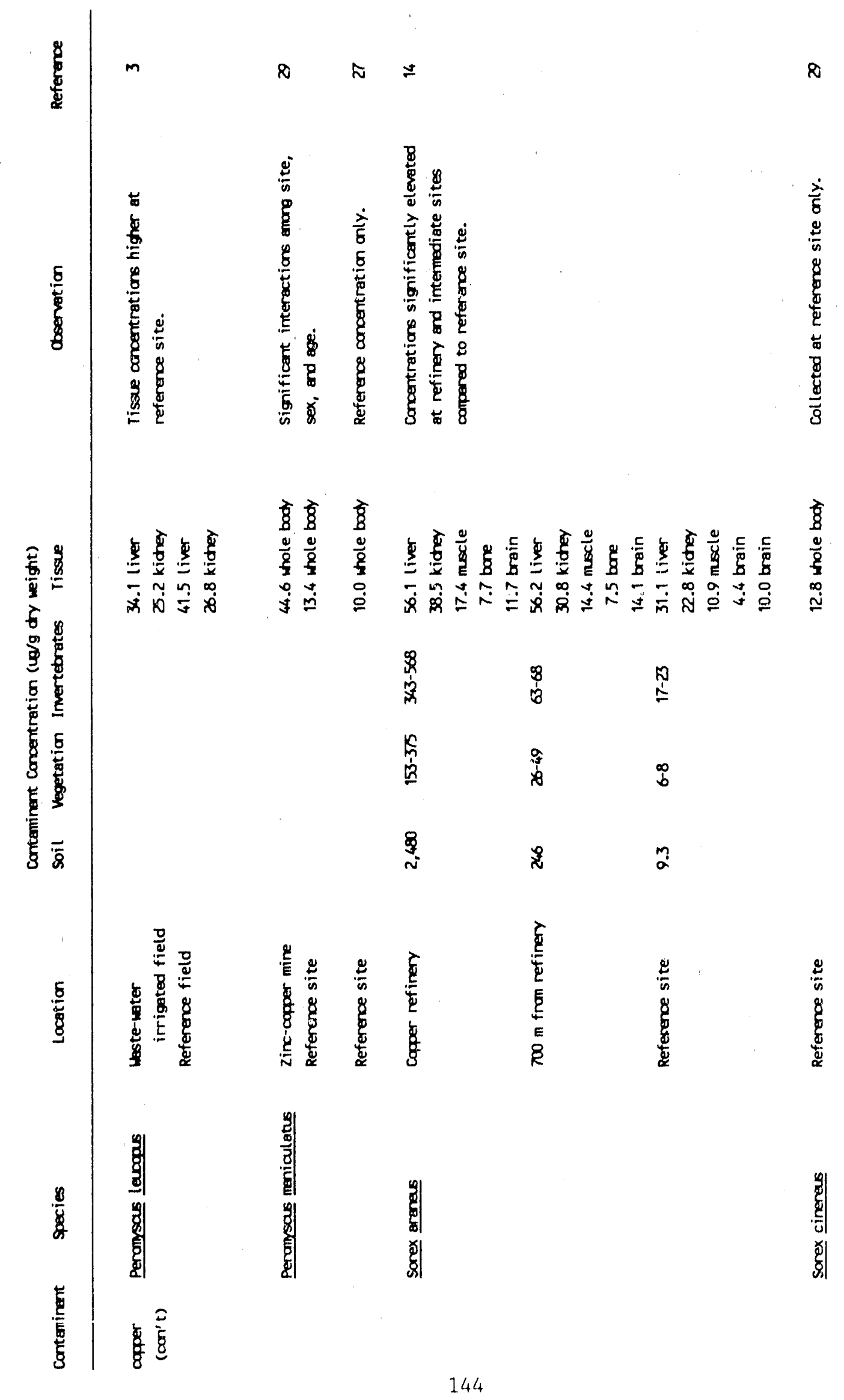




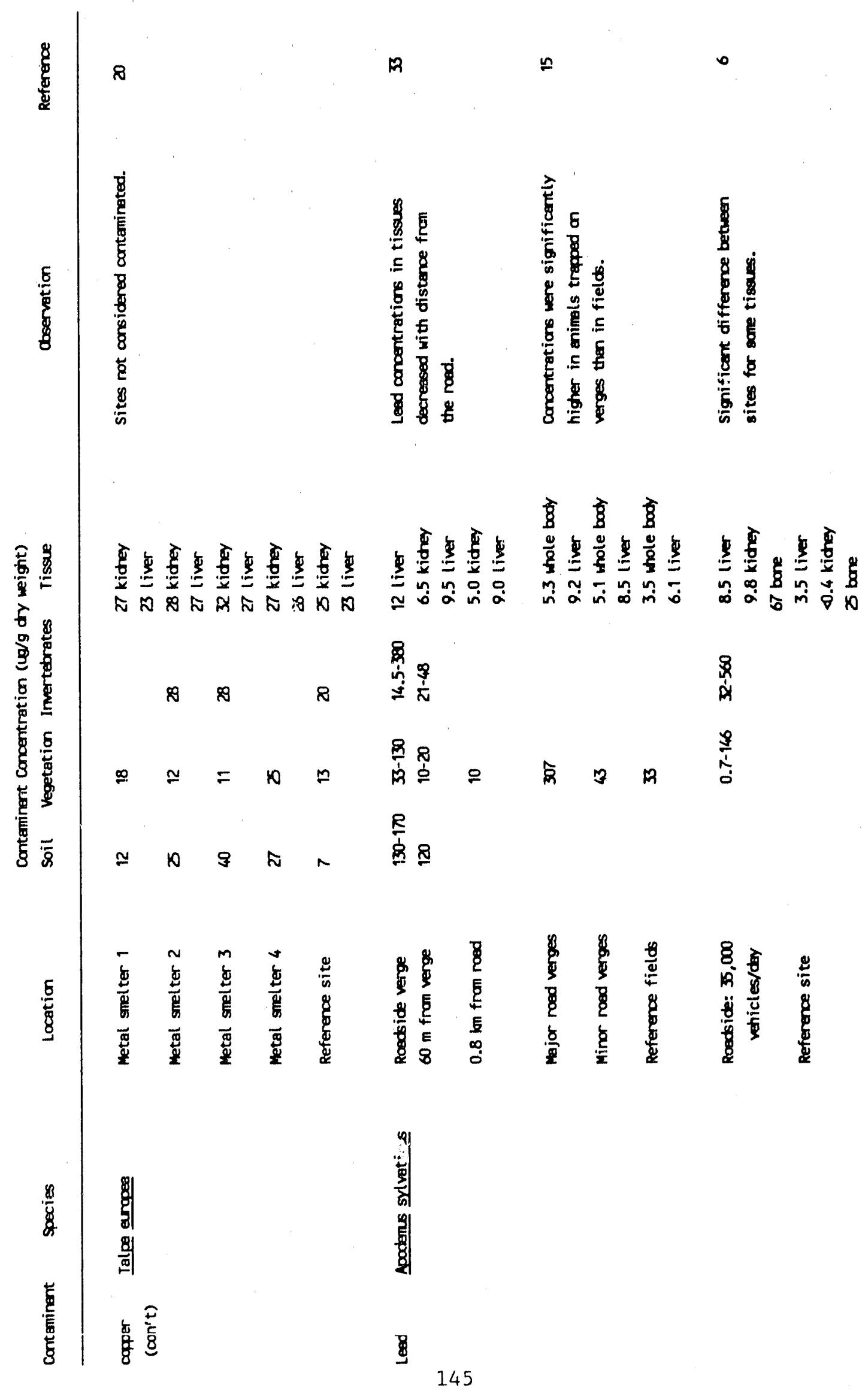




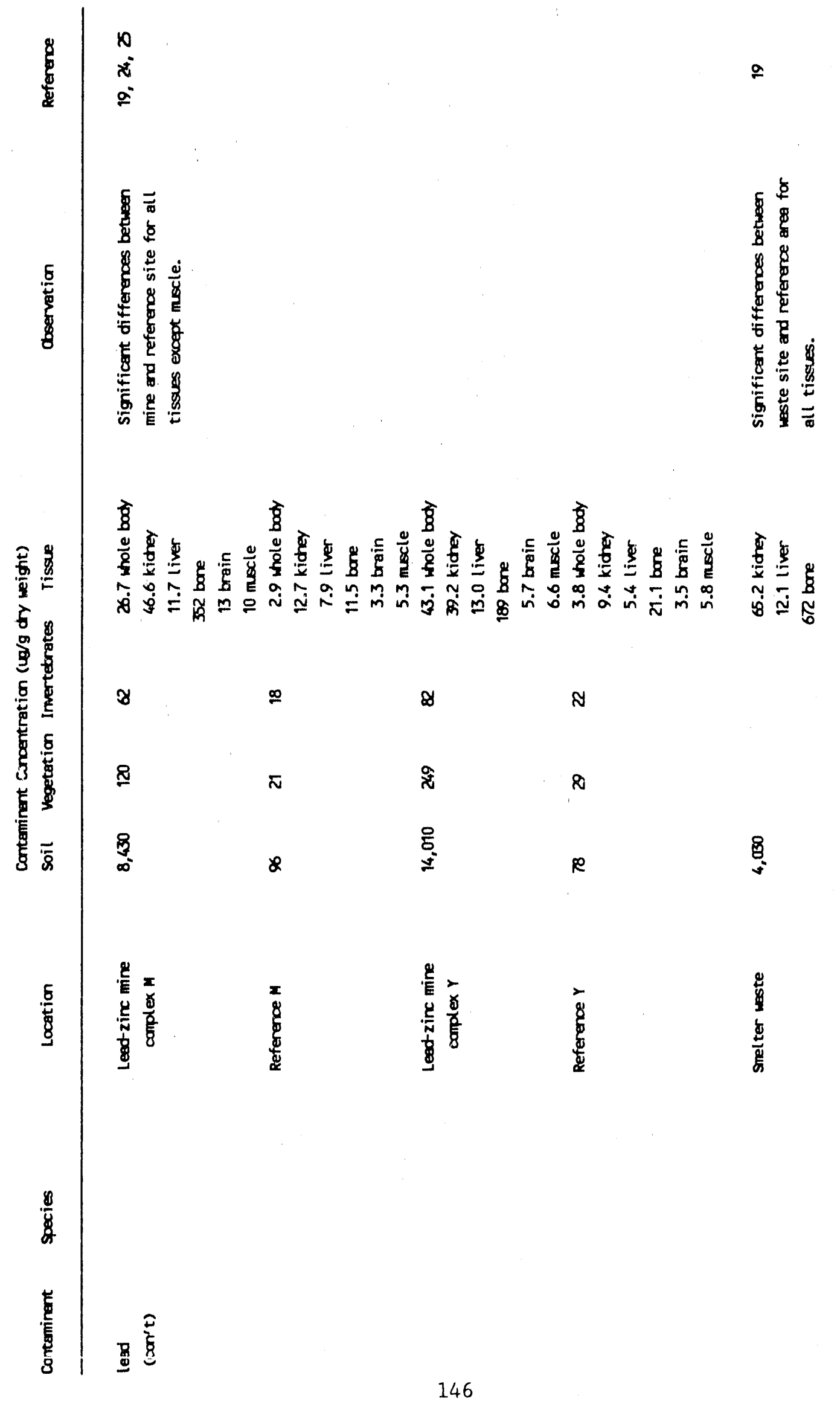




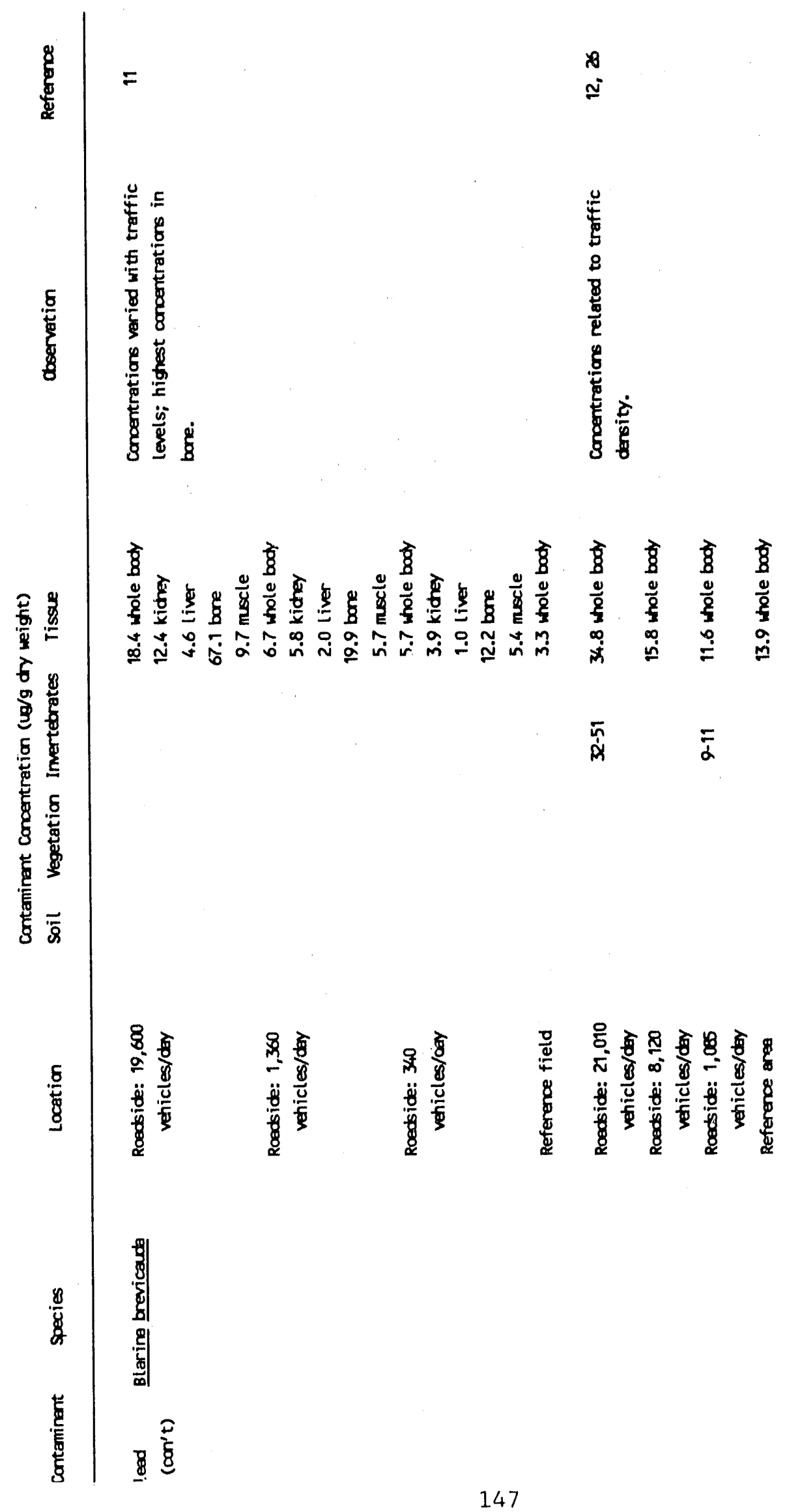




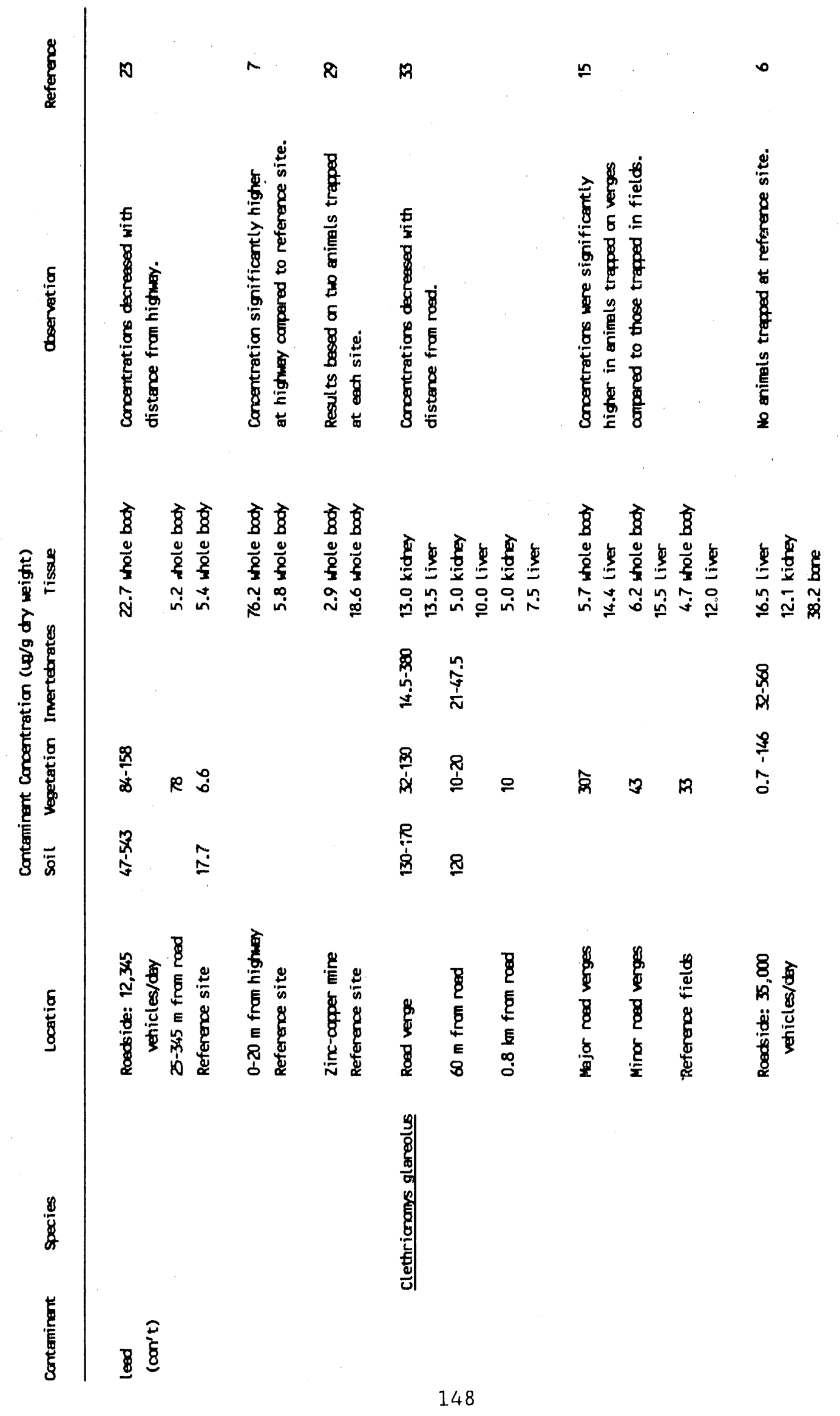




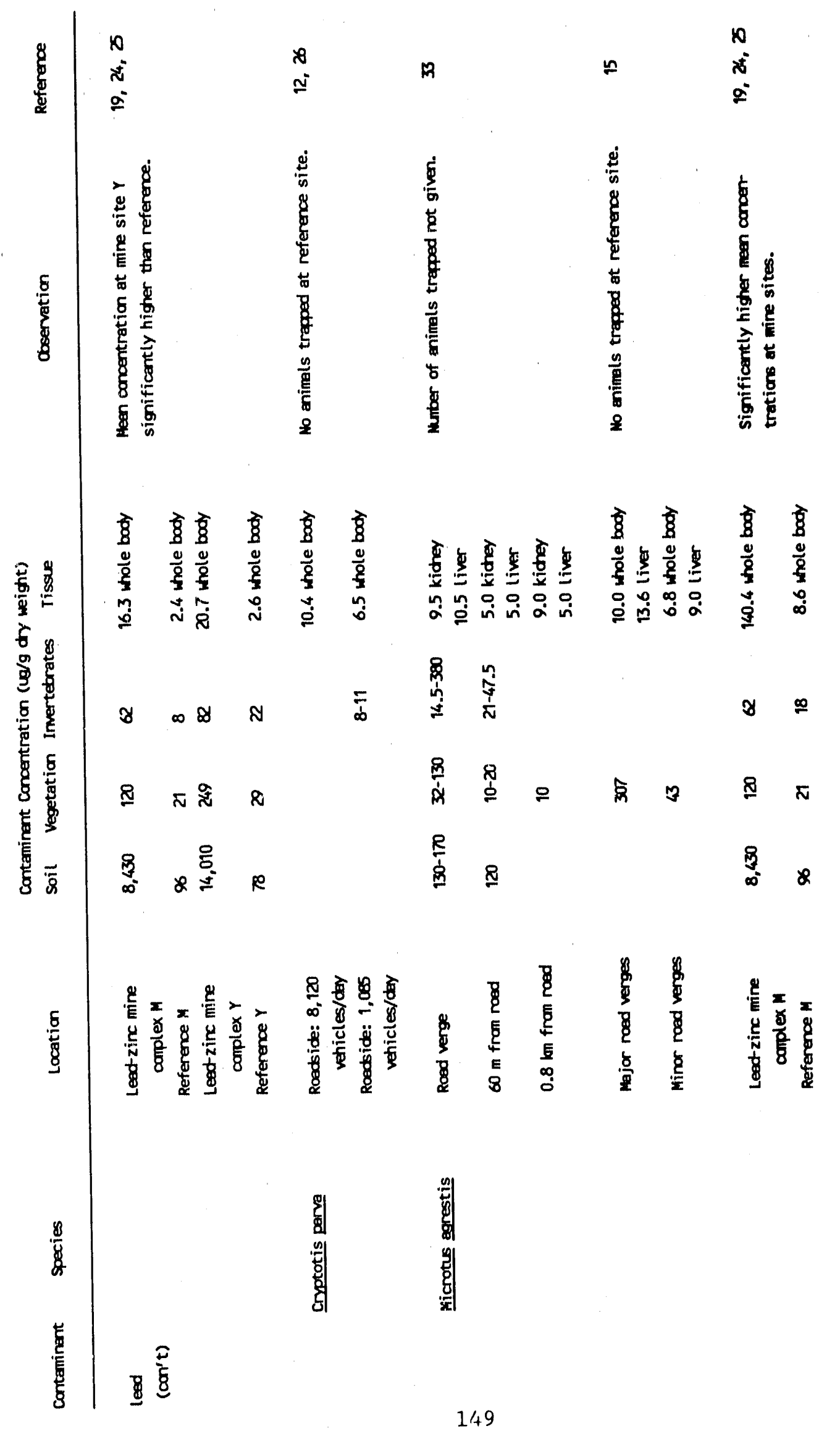




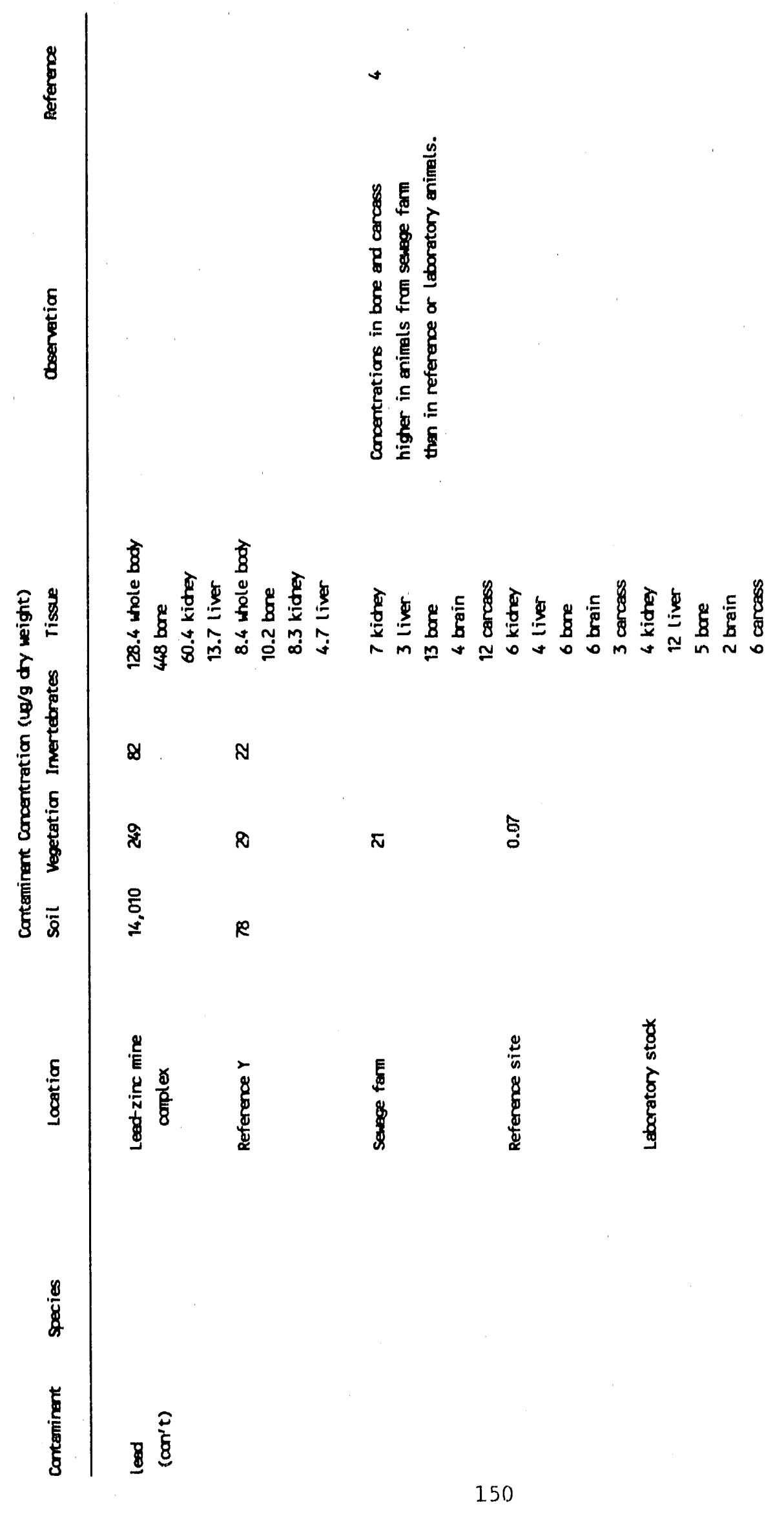




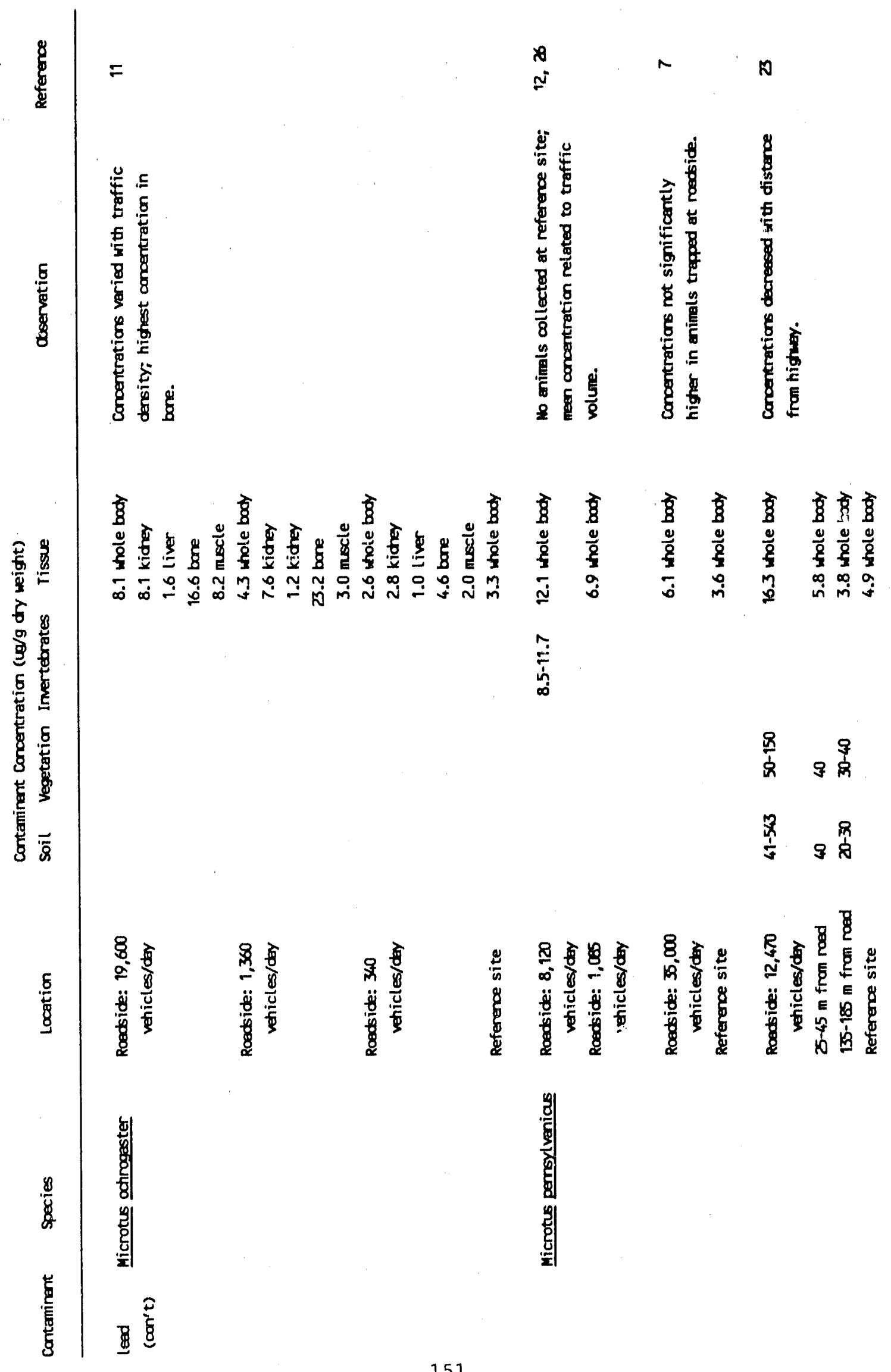




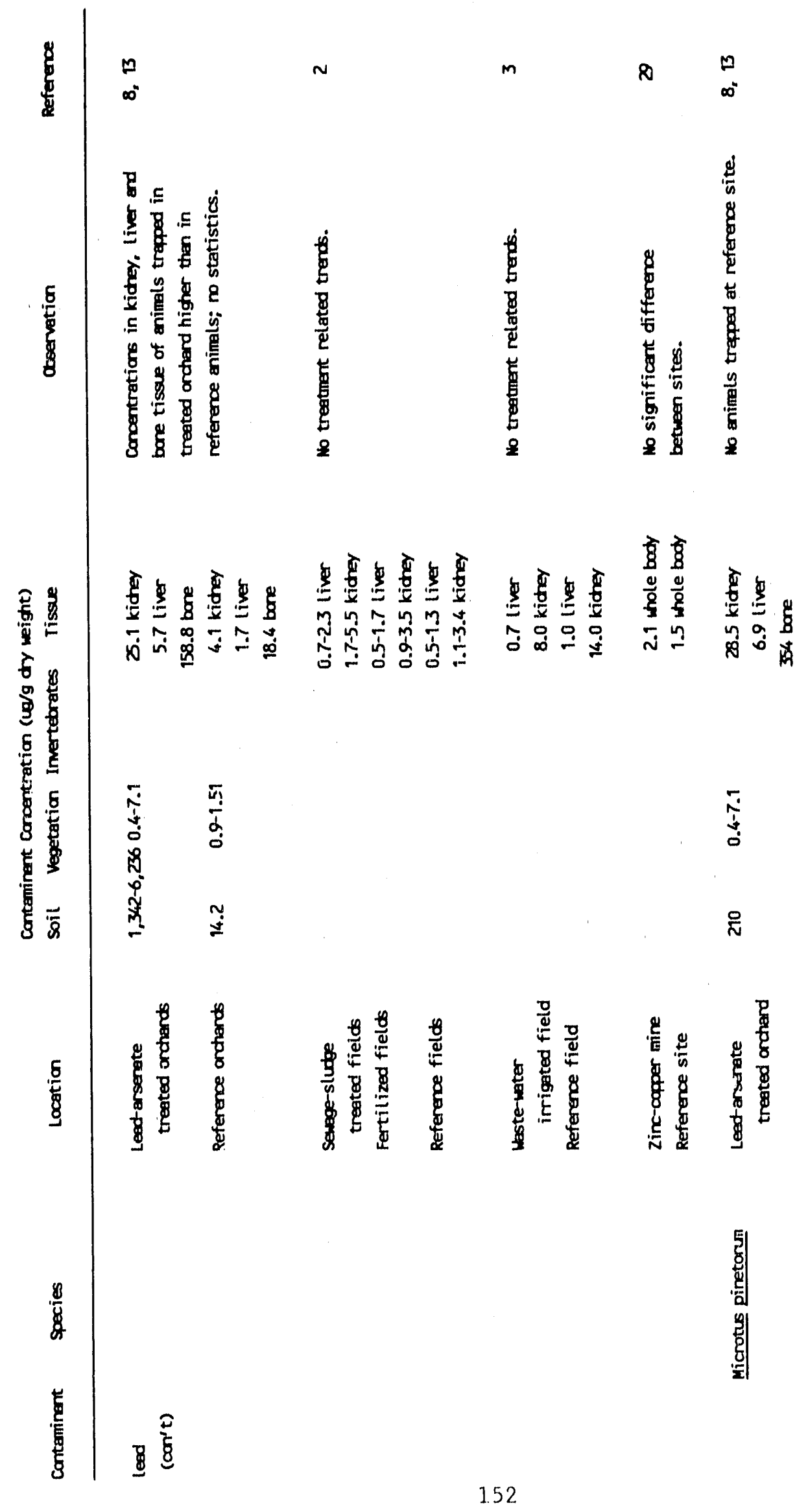




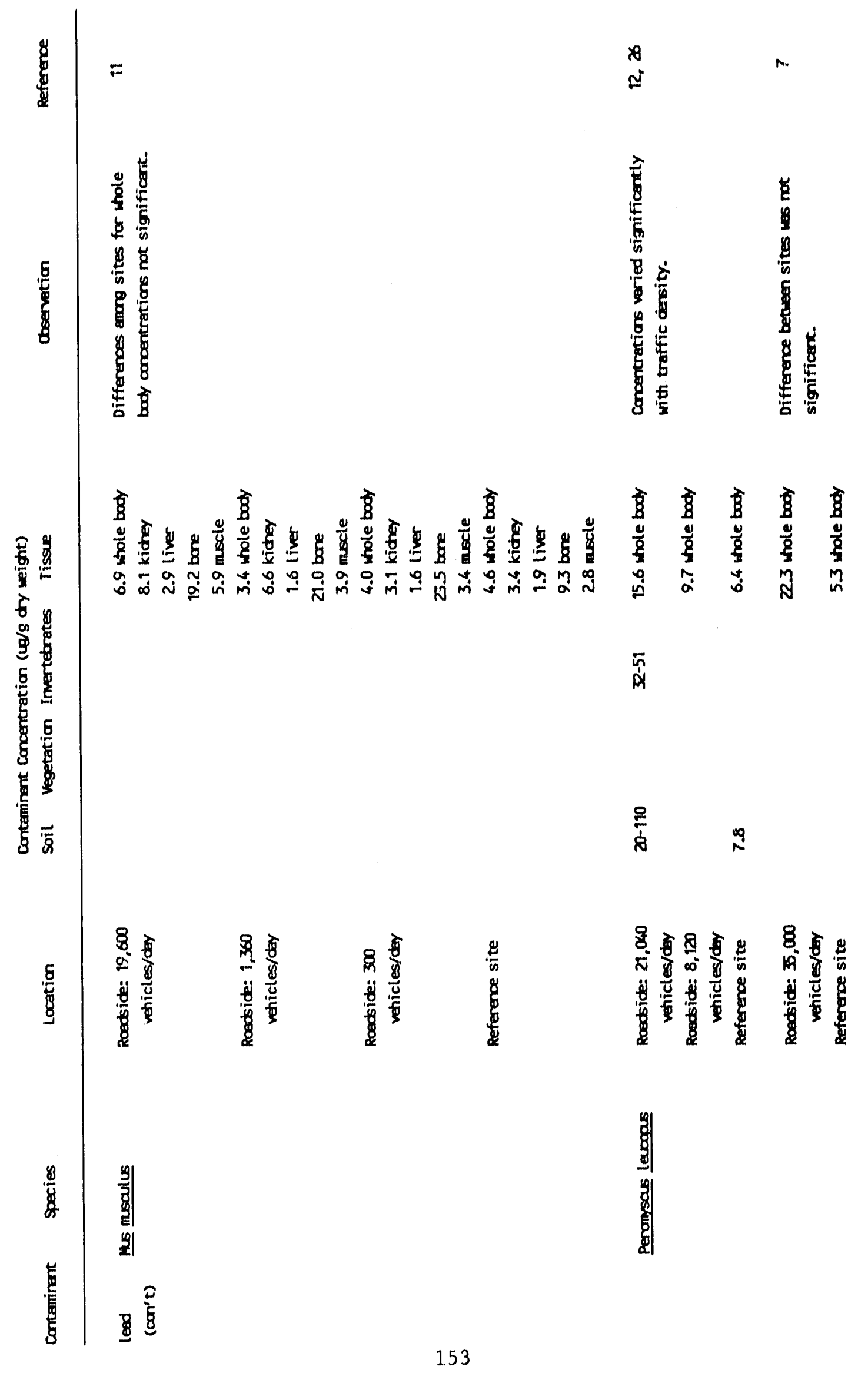




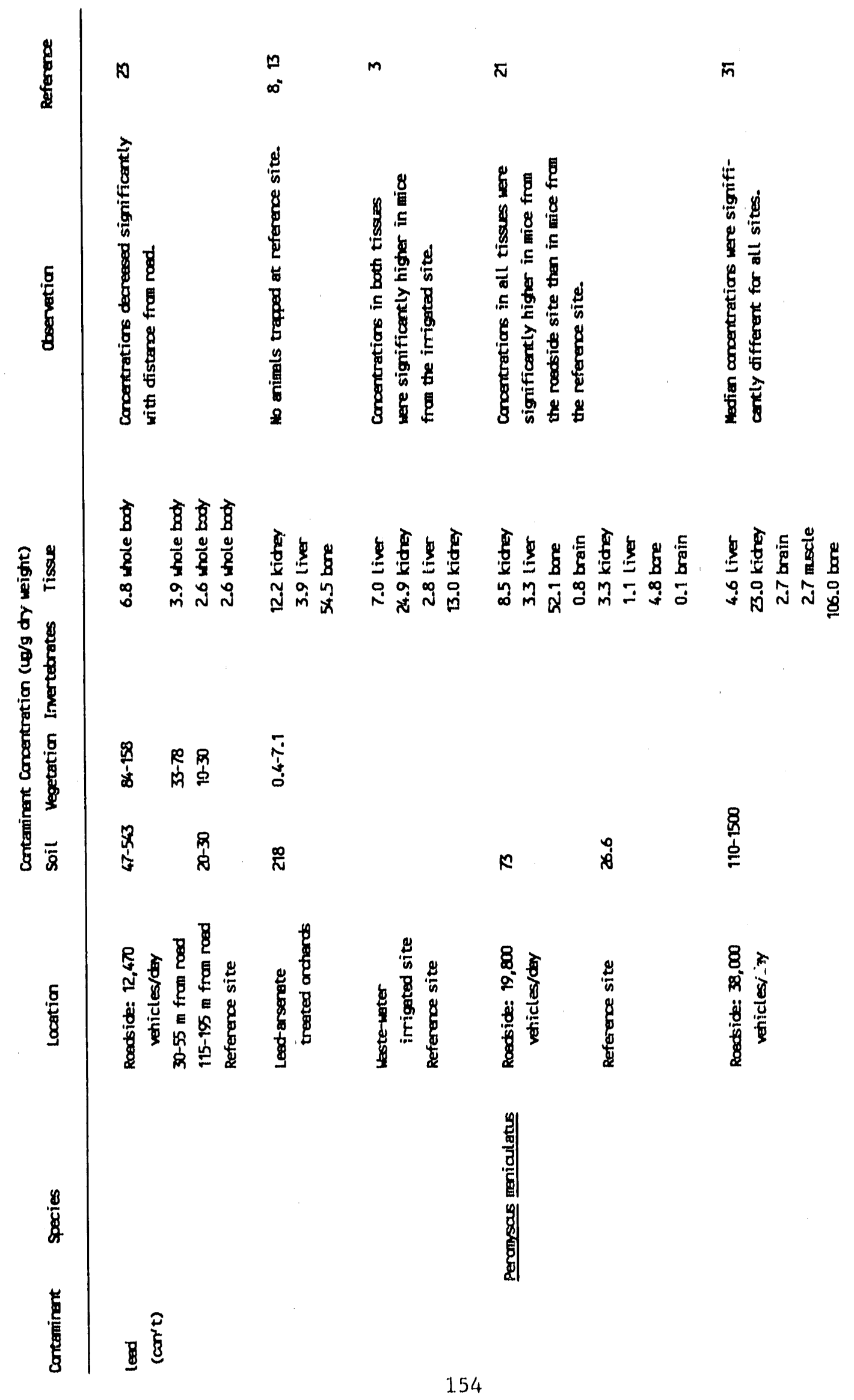




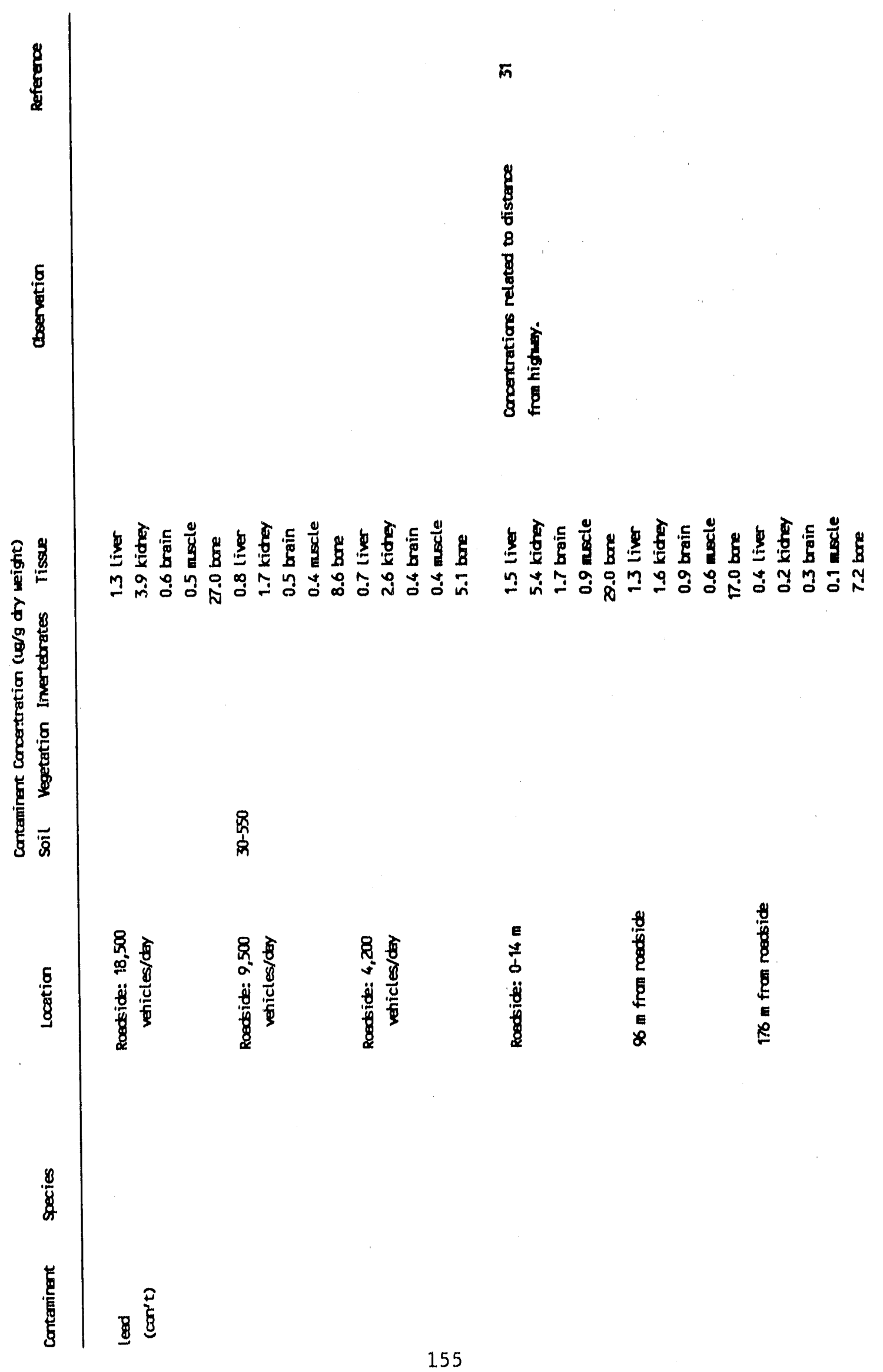




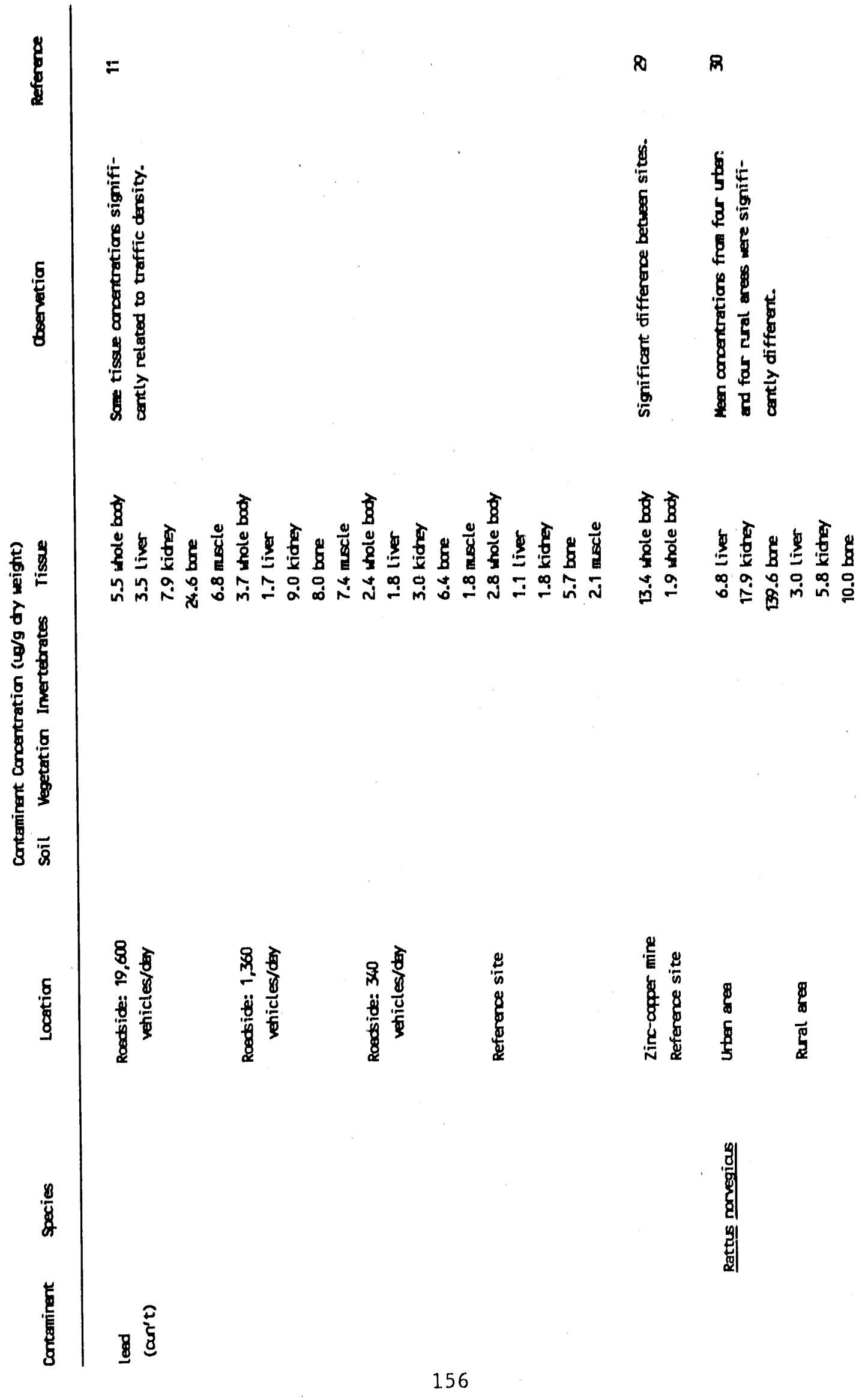




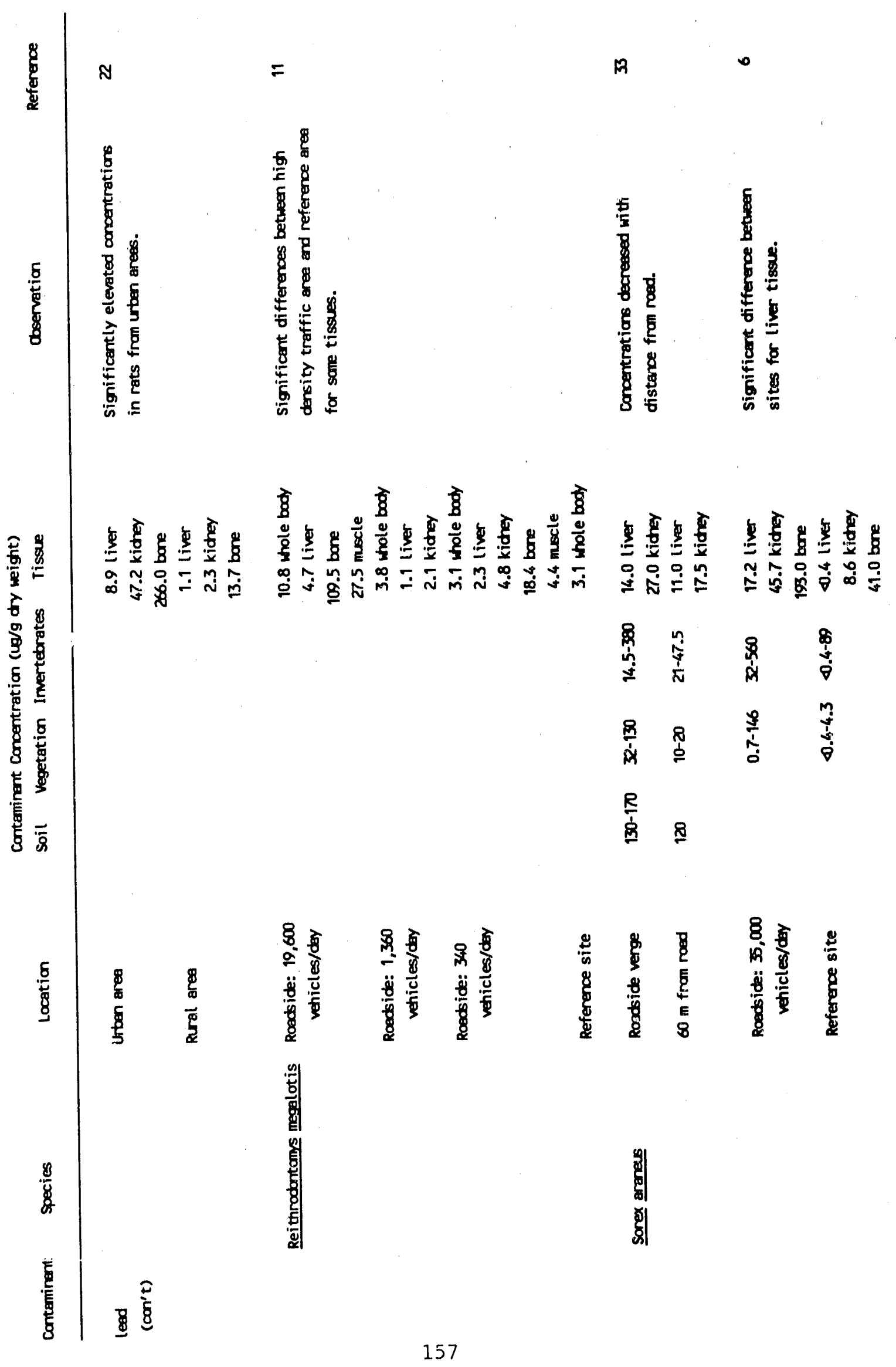




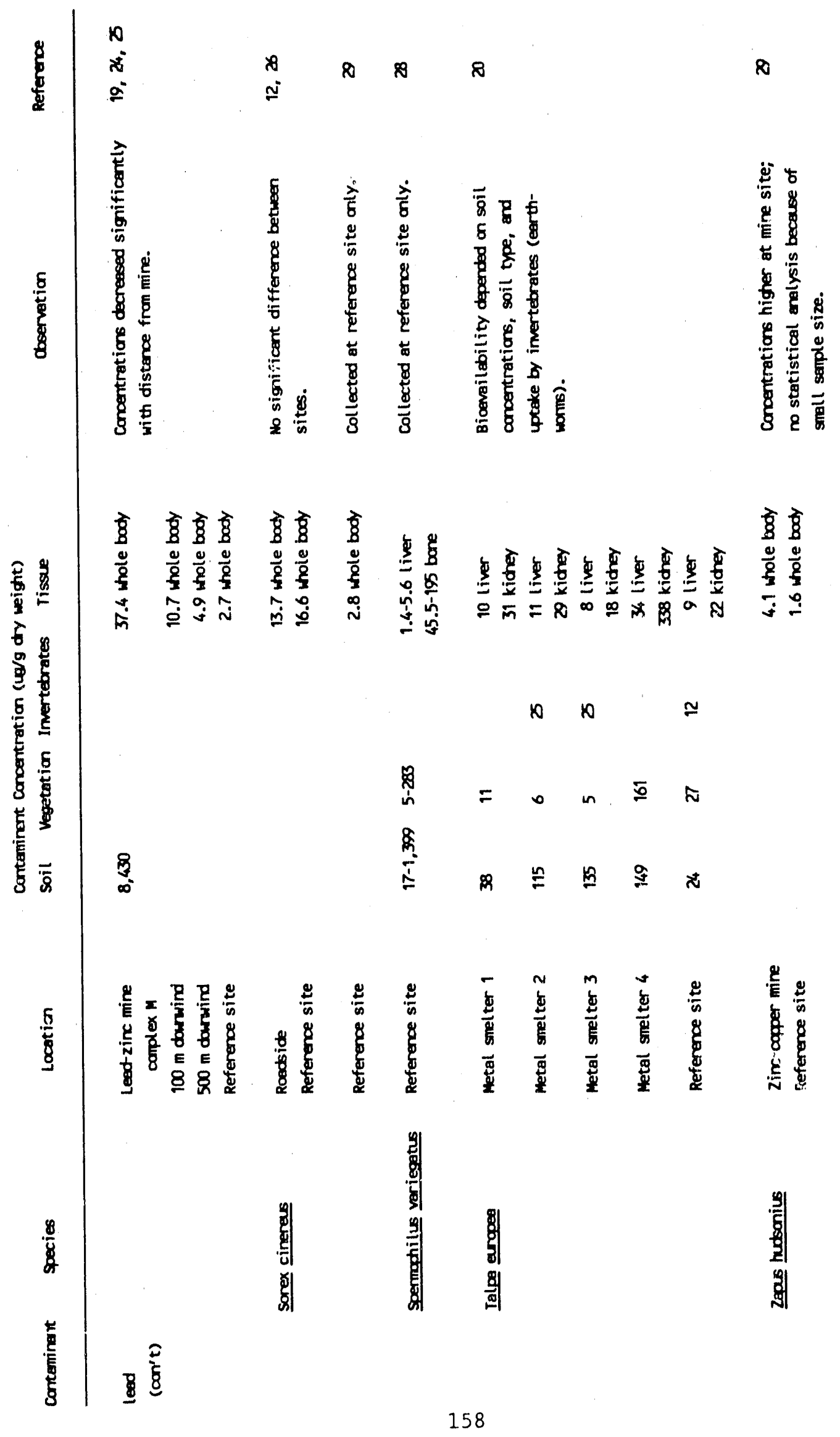









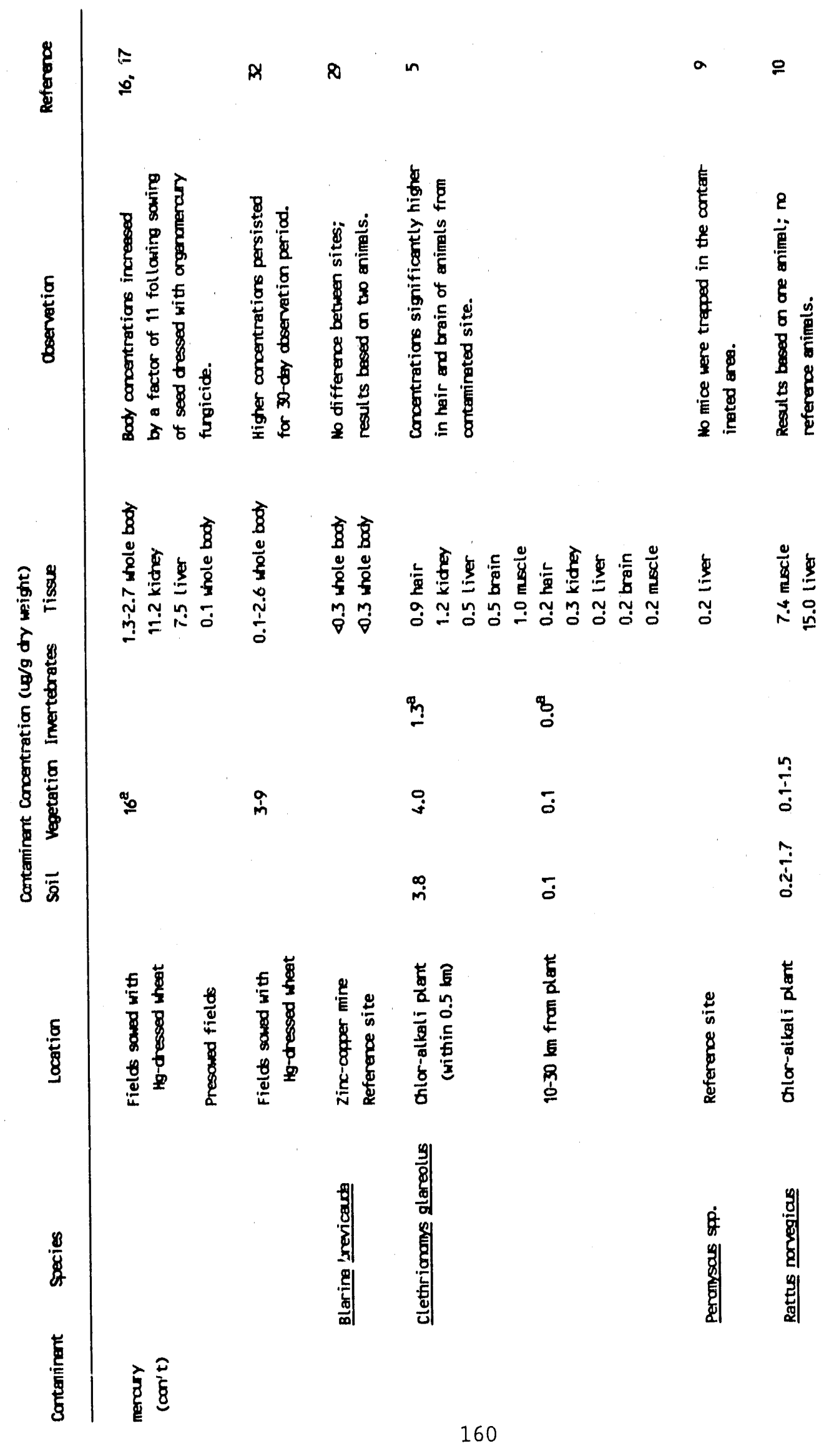




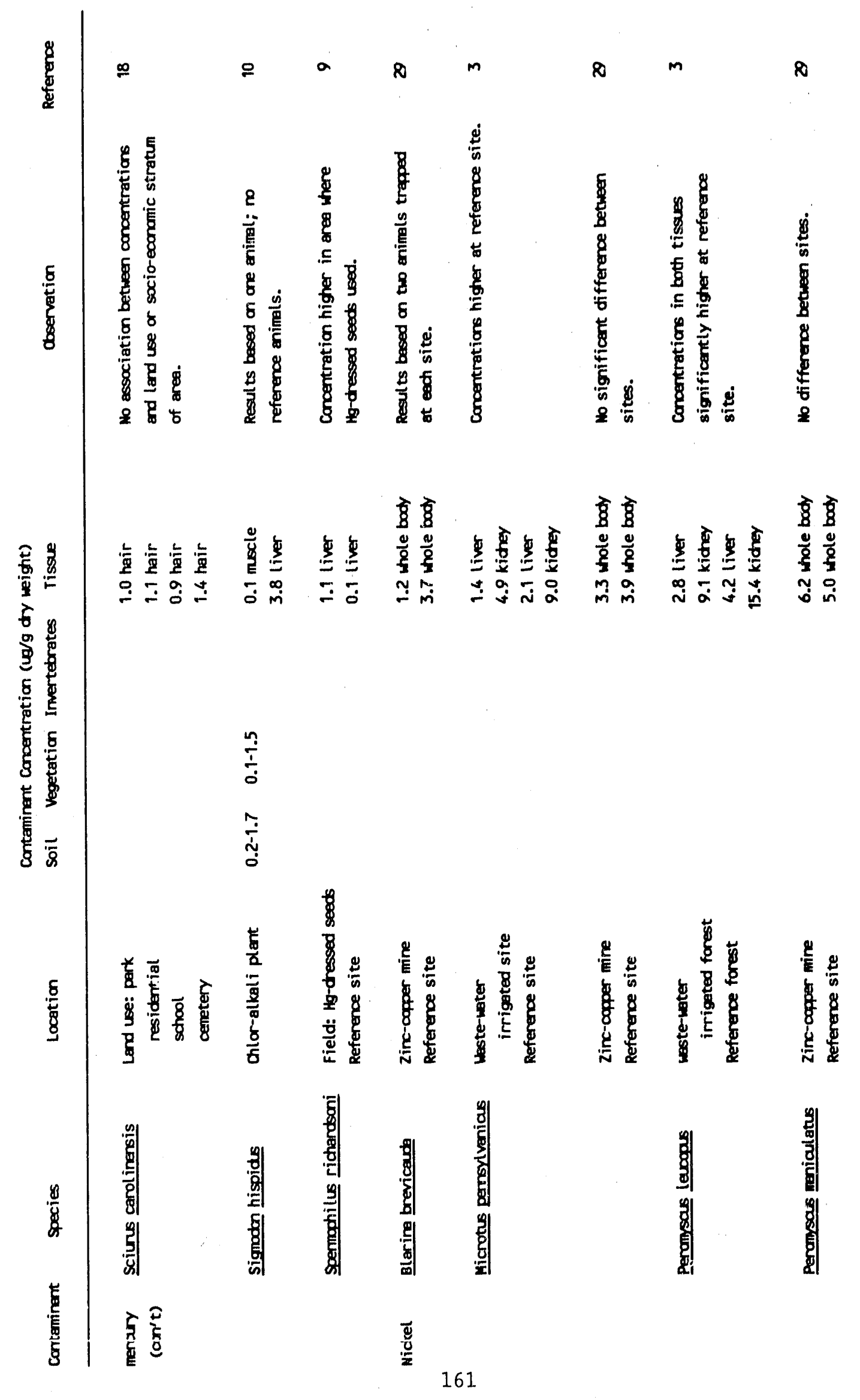




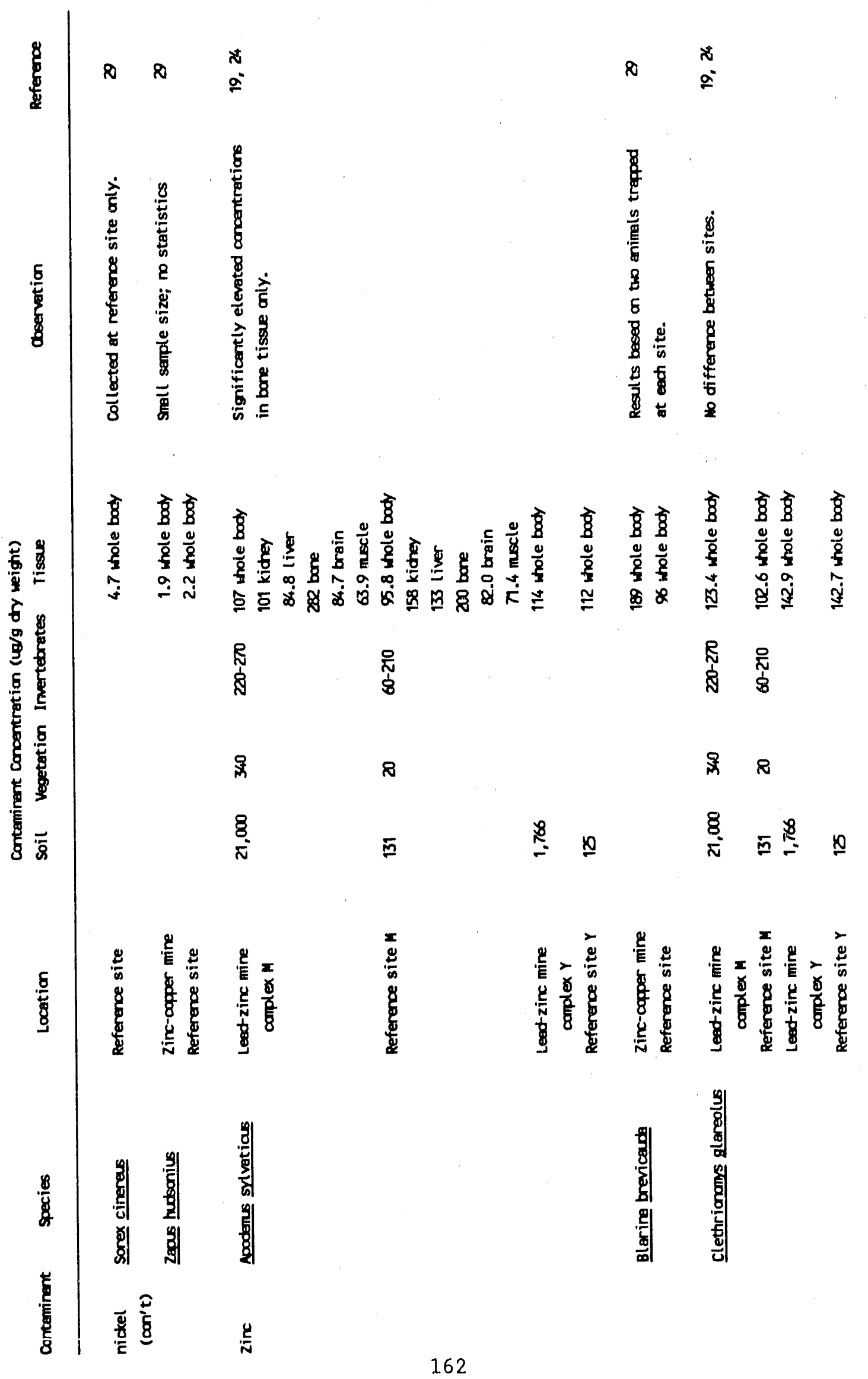




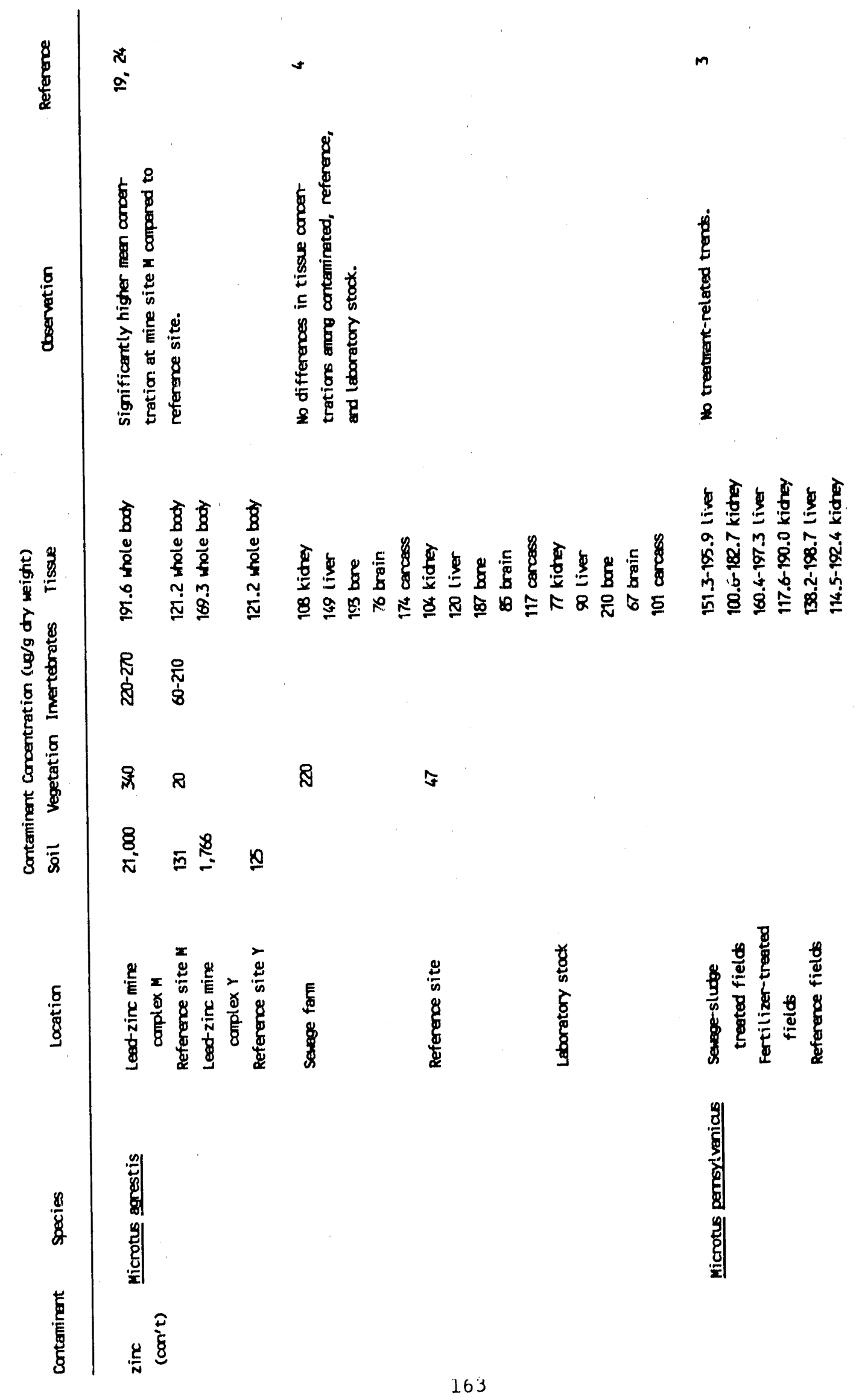




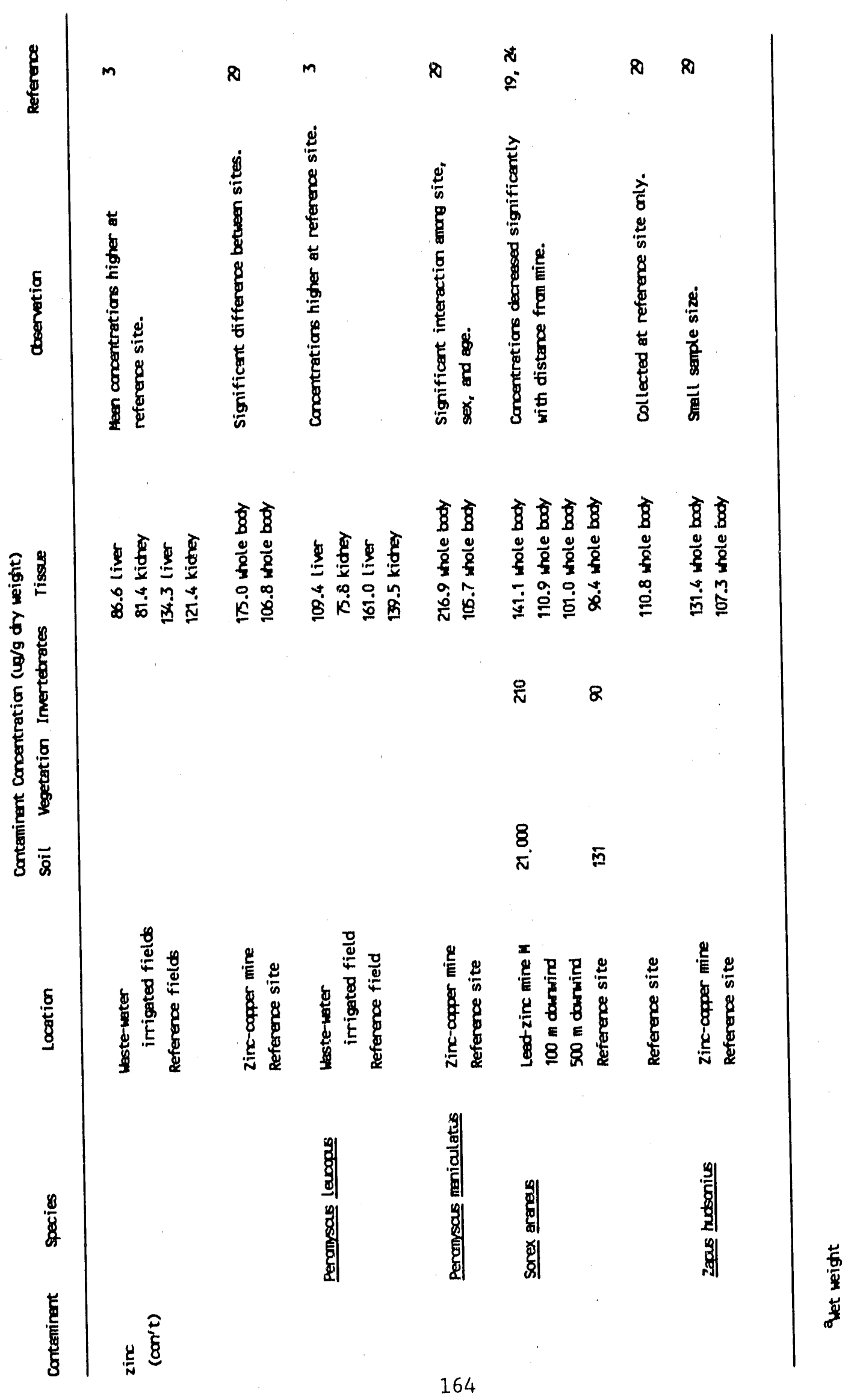




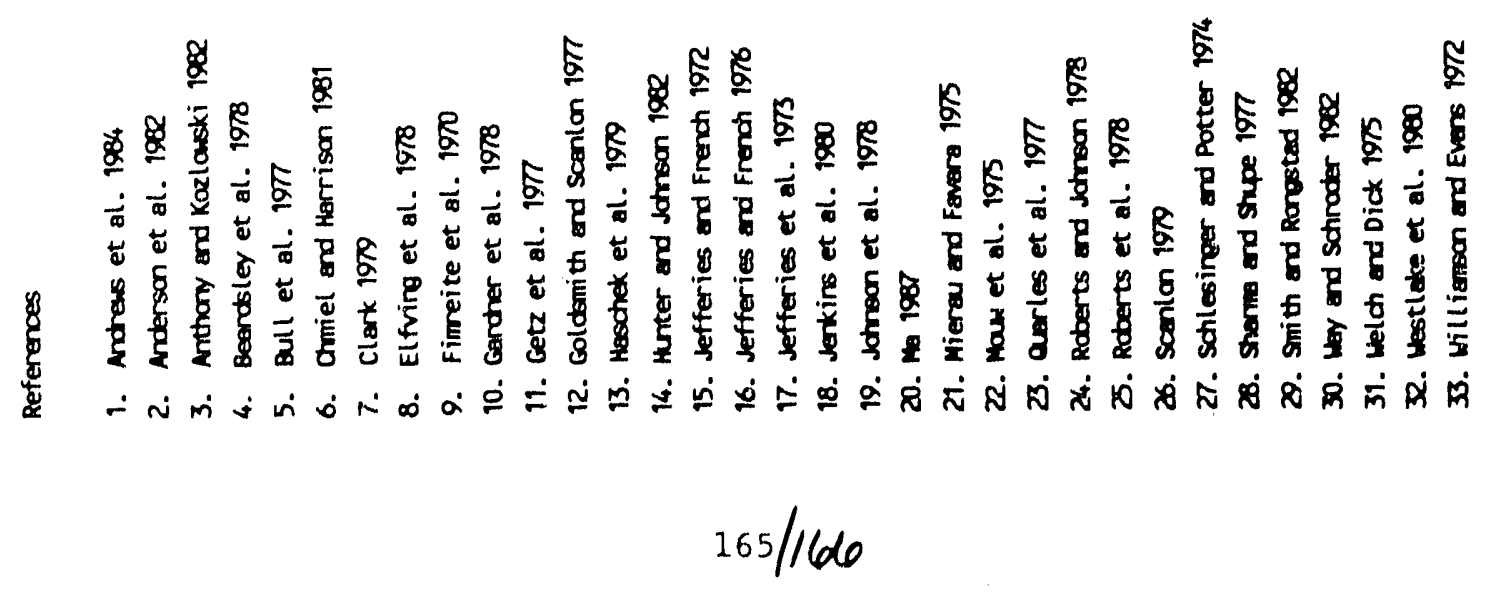


CONCENTRATIONS OF MERCURY IN KIDNEY TISSUE OF SMALL MAMMALS AT ORNL

Mercury concentrations (ug/g wet $w t$ ) in kidney tissue of individual antmals identified by site, species, and code.

Site Species $\begin{gathered}\text { Mercury } \\ \text { (ug/g wet wt) }\end{gathered}$

Laboratory control mouse $(n-6)$

0.02

WCK 2.1

\begin{tabular}{|c|c|c|c|}
\hline Peromyscus & leucopus & $(7-16 A)$ & 0.38 \\
\hline Peromyscus & leucopus & $(7 \cdot 16 \mathrm{C})$ & 0.15 \\
\hline Peromyscus & leucopus & $(7-16 E)$ & 0.27 \\
\hline Peromyscus & 1eucopus & $(7-16 I)$ & 0.25 \\
\hline Peromyscus & leucopus & $(7-16 \mathrm{~J})$ & 0.17 \\
\hline Peromyscus & 1eucopus & $(7-21 D)$ & 0.18 \\
\hline Peromyscus & 1eucopus & $(7-22 \mathrm{H})$ & 0.13 \\
\hline Peromyscus & leucopus & $(7-22 I)$ & 0.08 \\
\hline Peromyscus & leucopus & $(7-23 B)$ & 0.26 \\
\hline
\end{tabular}

WCK 3.4

Sigmodon hispidus (7-21B) 0.63

Reithrodontomys humilis $(7-21 \mathrm{~A}) \quad 0.42$

Peromyscus leucopus (7-21D) 0.27

Sigmodon hispidus (7-22B) 0.10

Sigmodon hispidus $(7-22 \mathrm{~A}) \quad 0.74$

Peromyscus leucopus $(5-13 \mathrm{~A}) \quad 0.46$

Sigmodon hispidus $(5-19 \mathrm{C}) \quad 0.52$

WCK 2.7

Peromyscus leucopus (7-21A) 0.35

Peromyscus leucopus $(7-21 \mathrm{C}) \quad 0.62$

Perainyscus leucopus $(7-21 \mathrm{~F}) \quad 0.20$

Peromyscus leucopus (7-22A) 0.26

Peromyscus leucopus $(7-22 F) \quad 0.41$

SWSA -4

Peromyscus leucopus ( $\mathrm{S}_{4} 5-27 \mathrm{~S}, 0, \mathrm{~S}_{4} 5-28 \mathrm{Q}$

$$
\left.\mathrm{S}_{4} 5-290\right) \quad 0.39
$$

Peromyscus leucopus $\left(\mathrm{S}_{4} 5-29 \mathrm{P}, \mathrm{S}_{4} 6-4 \mathrm{~V}, \mathrm{I}, \mathrm{T}\right) 1.33$

Microtus pinetorum ( $\left.\mathrm{S}_{4} 5-29 \mathrm{E}, \mathrm{S}_{4} 6-10 \mathrm{~J}\right) \quad 0.06$

Peromyscus leucopus $\left(\mathrm{S}_{4} 7-14 \mathrm{U}\right) \quad 0.60$ 


Site Species $\begin{gathered}\text { Mercury } \\ \text { (ug/g wet wt) }\end{gathered}$

\begin{tabular}{|c|c|}
\hline Peromyscus leucopus ( $S_{4} 7-14 \mathrm{~W}$ ) & 0.22 \\
\hline Peromyscus leucopus $\left(S_{4} 7-17 R\right)$ & 0.48 \\
\hline Peromyscus leucopus $\left(s_{4} 7-17 U\right)$ & 0.15 \\
\hline Peromyscus leucopus $\left(S_{4} 7-16 \mathrm{~V}\right)$ & 0.24 \\
\hline Re1throdontomys humulis $\left(\mathrm{S}_{4} 7-22 \mathrm{D}, \mathrm{H}\right)$ & 0.32 \\
\hline Blarina brevicauda $\left(S_{4} 7-22 F\right)$ & 0.36 \\
\hline Mus musculus $\left(\mathrm{S}_{4} 7-21 \mathrm{~K}\right)$ & 0.04 \\
\hline Tamias striatus $\left(\mathrm{S}_{4} 7-28 \mathrm{~T}\right)$ & 0.36 \\
\hline Tamias striatus ( $447-29 \mathrm{~S})$ & 0.05 \\
\hline Peromyscus leucopus ( $\left.S_{4} 7-21 \mathrm{BB}\right)$ & 0.55 \\
\hline Sigmodon hispldus $\left(S_{47} 7-22 B B\right)$ & 0.36 \\
\hline Re1throdontomys humilis $\left(\mathrm{S}_{4} 9-23 \mathrm{E}\right)$ & 0.27 \\
\hline Blarina brevicauda $\left(S_{4} 9-23 \mathrm{~F}\right)$ & 0.96 \\
\hline Sigmodon hispidug $\left(S_{4} 9-24 K\right)$ & 0.10 \\
\hline Blarina brevicauda (S49-24N) & 1.52 \\
\hline S1gmodon hispidus $\left(\mathrm{S}_{4} 11-17 \mathrm{~B}\right)$ & 0.26 \\
\hline Sigmodon hispidus $\left(S_{4} 11-17 \mathrm{C}\right)$ & 0.04 \\
\hline S1gmodon hispidus (S411-17D) & 0.02 \\
\hline Microtus pinecorum $\left(\mathrm{S}_{4}-7 \mathrm{~T}\right)$ & 0.06 \\
\hline Peromyscus leucopus $\left(S_{4} 5-17 \mathrm{~V}\right)$ & 0.20 \\
\hline Microtus pinetorum $\left(5_{4} 5-19 S\right)$ & 0.01 \\
\hline Peromyscus leucopus ( $\left.\mathrm{S}_{4} 5-19 \mathrm{CC}\right)$ & 0.82 \\
\hline
\end{tabular}

EFPC

\begin{tabular}{|c|c|c|}
\hline Peromyscus Leucopus & $(E 8-3 A)$ & 0.60 \\
\hline Peromyscus leucopus & $(E 8-3 B)$ & 0.51 \\
\hline Peromyscus leucopus & $(E 8-4 A)$ & 5.5 \\
\hline Peromyscus leucopus & $(E 8-4 B)$ & 3.1 \\
\hline Peromyscus leucopus & $(E 8-5 B)$ & 0.62 \\
\hline Blarina brevicauda & $(E 8-5 A)$ & 57. \\
\hline Peromyscus leucopus & $\begin{array}{c}(E 8-14 A, E 8-5 A, \\
E 8-6 A, E 8-5 B)\end{array}$ & 0.78 \\
\hline $7 / 2$ & $\begin{array}{l}(E 8-15 A, E 8-15 C \\
4 / 86, D O A, 10 / 16 / 85)\end{array}$ & 21. \\
\hline Sigmodon hispidus ( & $E 8-15 B)$ & 1.9 \\
\hline Peromyscus leucopus & $(E 8-6 x, 7,3)$ & 1.94 \\
\hline Peromyscus leucopus & $(E 8-7(11), E 8-13(6)$ & 1.08 \\
\hline Peromyscus leucopus & $(E 8-13(2), E 8-13(27)$ & 0.97 \\
\hline Peromyscus leucopus & $(\mathrm{E} 9-27(21 \mathrm{~A}),(27))$ & 0.70 \\
\hline Peromyscus leucopus & $(E 9-26(6), E-10-15)$ & 0.82 \\
\hline Blarina brevicauda & $($ E9-14) & 73 \\
\hline Blarina brevicauda & (E9-15A) & 42. \\
\hline Blarina brevicauda & $(E 9-15 B)$ & 43. \\
\hline Peromyscus & $(E 7-2 A)$ & 0.78 \\
\hline bus & $(E 7-14 t$ & 0.76 \\
\hline
\end{tabular}




\begin{tabular}{|c|c|c|}
\hline Site & Species & $\begin{array}{r}\text { Merc } \\
(\mathrm{ug} / \mathrm{g} \text { w }\end{array}$ \\
\hline \multirow[t]{16}{*}{ EFPC } & $\left(\operatorname{con}^{\prime} t\right)$ & \\
\hline & Peromyscus leucopus (E7-17Q) & 1.58 \\
\hline & Peromyscus Leucopus (E7-23P) & 1.19 \\
\hline & Peromyscus leucopus (E7-25E) & 0.90 \\
\hline & Peromyscus leucopus (E7-29C) & 1.77 \\
\hline & Rattus norvegicus (E7-3UA) & 4.77 \\
\hline & Peromyscus leucopus (E7-31A) & 0.42 \\
\hline & Peromyscus leucopus (E7-31B) & 0.08 \\
\hline & Peromyscus leucopus (E8-7A) & 0.59 \\
\hline & Blarina brevicauda (E8-7B) & 58.50 \\
\hline & Blarina b-avicauda (E8-15C) & 0.96 \\
\hline & Peromyscus leucopus (E9-24A) & 0.31 \\
\hline & Peromyscus Leucopus (E9-24B) & 0.62 \\
\hline & Blarlna brevicauda (E9-29L) & 14.80 \\
\hline & Peromyscus leucopus (E10-16A) & 0.87 \\
\hline & Rattus noryegicus (E10-17A) & 5.17 \\
\hline
\end{tabular}


APPENDIX C

CONCENTRATIONS OF MERCURY IN SOIL AT ORNL

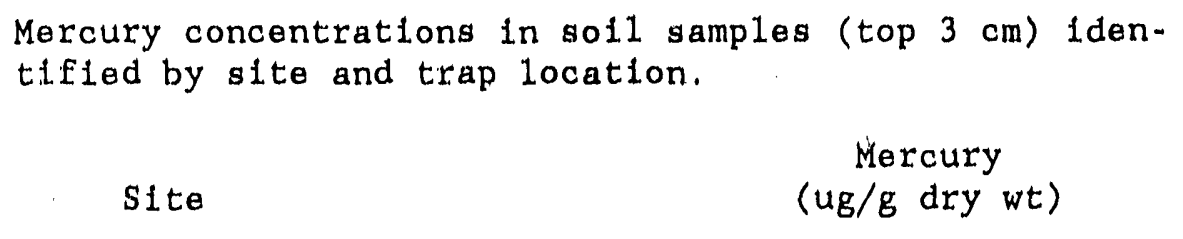

WCK 2.1

Trap A

3.5

Trap E

2.3

Trap I

2.0

WCK 3.4

Trap A

6.6

Trap B

7.3

WCK 2.7

Trap A

Trap B

0.34

Trap C

0.89

1.3

SWSA - 4

$\begin{array}{ll}\text { Trap B } & 0.32\end{array}$

Trap H $\quad 0.28$

$\begin{array}{ll}\text { Trap Q } & 0.15\end{array}$

Trap V 0.17

Trap V $\quad 0.09$

Trap U $\quad 0.24$

EF'PC

$1-20 \mathrm{~cm}(2) \quad 348$

$30-40 \mathrm{~cm}(2) \quad 1665$ 
CONCENTRATIONS OF STRONTIUM-90 IN BONES OF SMALL MAMMALS AT ORNL

\begin{tabular}{|c|c|}
\hline Species & $\begin{array}{l}\text { Strontium }-90 \\
(\mathrm{~Bq} / \mathrm{g} \text { dry } w t)\end{array}$ \\
\hline Laboratory control mouse ( 7 samples) & n.d. \\
\hline \multicolumn{2}{|l|}{ SWSA -4} \\
\hline Peromyscus leucopus $\left(S_{4} 5-270\right)$ & 5.67 \\
\hline Peromyscus leucopus $\left(S_{4} 5-27 \mathrm{~S}\right)$ & 1.64 \\
\hline Peromyscus leucopus $\left(\mathrm{S}_{4} 5-28 \mathrm{Q}\right)$ & 3.97 \\
\hline Tamias striatus $\left(\mathrm{S}_{4} 5-28 \mathrm{~T}\right)$ & 8.91 \\
\hline Microtus pinetorum $\left(S_{4} 5-29 E\right)$ & 1.45 \\
\hline Peromyscus leucopus $\left(\mathrm{S}_{4} 5-290\right)$ & 3.81 \\
\hline Tamias striatus $\left(\mathrm{S}_{4} 5-29 \mathrm{~S}\right)$ & 0.95 \\
\hline Peromyscus leucopus ( $\left.S_{4} 5-29 \mathrm{P}\right)$ & 4.29 \\
\hline Reithrodontomys humulis $\left(S_{4} 6-4 D\right)$ & 10.43 \\
\hline Peromyscus leucopus $\left(\mathrm{s}_{4} 6-4 \mathrm{~V}\right)$ & 0.85 \\
\hline Peromyscus leucopus $\left(S_{4} 6-4 I\right)$ & 1.56 \\
\hline Peromyzicus leucopus $\left(S_{4} 6-4 \mathrm{~T}\right)$ & 2.34 \\
\hline Re1th codontomys humulis $\left(S_{4}^{6-10 B}\right)$ & 0.04 \\
\hline Microtus pinetorum $\left(\mathrm{S}_{4} 6-10 \mathrm{~J}\right)$ & 31.81 \\
\hline Peromyscus leucopus $\left(\mathrm{S}_{4} 7 \cdot 14 \mathrm{U}\right)$ & 3.85 \\
\hline Peromyscus leucopus $\left(S_{4} 7-14 \mathrm{~W}\right)$ & 3.40 \\
\hline Peromyscus leucopus $\left(\mathrm{S}_{4} 7-16 \mathrm{~V}\right)$ & 1.20 \\
\hline Peromyscus leucopus $\left(\mathrm{S}_{4} 7-17 \mathrm{R}\right)$ & 48.76 \\
\hline Peromyscus leucopus $\left(S_{4} 7-17 \mathrm{U}\right)$ & 9.88 \\
\hline Mus musculus $\left(\mathrm{S}_{47} 71 \mathrm{~K}\right)$ & 1.29 \\
\hline Peromyscus leucopus $\left(S_{4} 7-21 B B\right)$ & 86.11 \\
\hline Reithrodontomys humu1is ( $\left.4_{4} 7-22 \mathrm{D}\right)$ & 16.00 \\
\hline Blaina brevicauda $\left(\mathrm{S}_{47}-22 \mathrm{~F}\right)$ & 3.90 \\
\hline Reithrodontomys humulis $\left(\mathrm{S}_{4} 7-22 \mathrm{H}\right)$ & 10.17 \\
\hline Sigmodon hispidus $\left(\mathrm{S}_{4} 7-22 \mathrm{BB}\right)$ & 1.33 \\
\hline Reithrodontomys humulis $\left(S_{4} 9-23 E\right)$ & 280.76 \\
\hline Blarina brevicauda $\left(\mathrm{S}_{4} 9-23 \mathrm{~F}\right)$ & 4.99 \\
\hline Stgmodon hispidus $\left(S_{4}^{4}-24 \mathrm{~K}\right)$ & 51.64 \\
\hline Blarina brevicauda ( $\left.S_{4} 9-24 N\right)$ & 61.72 \\
\hline Sigmodon hispidus (S $411-17 \mathrm{~B})$ & 111.82 \\
\hline Sigmodon hispidus $\left(S_{4} 11-17 C\right)$ & 74.80 \\
\hline SLgmodon hispldus $\left(S_{4} 11-17 D\right)$ & 49.46 \\
\hline
\end{tabular}




$\begin{array}{ll}\text { Site } & \text { Strontium-90 } \\ \text { (Bq/g dry } w t)\end{array}$

SWSA-4 (con't)

Microtus pinetorum $\left(\mathrm{S}_{4} 4-7 \mathrm{~T}\right) \quad 38.03$

Peromyscus leucopus ( $\left.\mathrm{S}_{45} 5-17 \mathrm{~V}\right) \quad 66.67$

Microtus pinetorum $\left(\mathrm{S}_{4} 5-19 \mathrm{~S}\right) \quad 78.79$

Peromyscus leucopus $\left(\mathrm{S}_{4} 5-19 \mathrm{CC}\right) \quad 0.30$

WCK 2.1

Perom $\approx$ leucopus $(7-16 \mathrm{~A}) \quad 0.19$

Peromyscus leucopus_(7-16C) 1.60

Peromyscus leucopus (7-16E) $\quad 1.08$

Pnromyscus leucopus (7-16I) 2.49

Peromyscus leucopus (7-16J) 4.69

Peromyscus leucopus (7-21D) 2.15

Peromyscus 1eucopus $(7-22 \mathrm{H}) \quad 0.14$

Peromysous leucopus (7-22I) 0.75

Peromyscus leucopus (7-23B) 1.22

WCK $\because 4$

Reilhrodontomys humulis (7-21A) 0.93

Sigmodon hispidus (7-21B) 14.46

Peromyscus leucopus (7-21D) $\quad 0.62$

Sigmodon hispidus $(7-22 \mathrm{~A}) \quad 3.58$

Sigmodon hispidus (7-22B) $\quad 44.06$

Peromyscus leucopus (5-13A) $\quad 1.62$

Sigmodon hispidus $(5-19 \mathrm{C}) \quad 15.04$

WCK 2.7

Peromyscus leucopus (7-21A) 1.36

Peromyscus leucopus (7-21C) 1.36

Peromyscus leucopus $(7-21 \mathrm{~F}) \quad 1.43$

Peromyscus leucopus (7-22A) 0.32

Peromyscus leucopus (7-22F) 3.66

EFPC

Leromyscus leucopus (E8-6[x]) n.d.

Peromyscus leucopus (E8-6[11]) n.d.

Peromyscus leucopus (E8-3A) 0.02

Peromyscus leucopus (E8-3R) 0.05

Peromyscus leucopus (E8-4i ) n.d.

Peromyscus leucopus (E8-4B) n.d.

Blarina brevicauda (E8-5A) n.d.

Peromyscus leucopus (E8-5B) n.d.

Blarina brevicauda (E9-14A) n.d.

Blarina brevicauda (E9-15A). 0.44

Blarina brevicauda (E9-15B) n.d.

Peromyscus leucopus (E7-2A) 0.33 


\begin{tabular}{|c|c|c|}
\hline S & Species & $\begin{array}{l}\text { Strontium } \\
(\mathrm{Bq} / \mathrm{g} \text { dry }\end{array}$ \\
\hline \multirow[t]{21}{*}{ EFPC } & $\left(\operatorname{con}^{\prime} t\right)$ & \\
\hline & Rattus norvegicus (E7-17A) & $\mathrm{n}$. \\
\hline & Peromyscus leucopus (E7-17Q) & \\
\hline & Peromyscus leucopus $(7-23 P)$ & \\
\hline & Peromyscus leucopus (E7-25E) & $\mathrm{n}$ \\
\hline & Peromyscus 1eucopus (E7-29C) & 0. \\
\hline & Blarina brevicauda (E7-29L) & \\
\hline & Rattus norvegicus (E7-30A) & \\
\hline & Peromyscus leucopus (E7-31A) & \\
\hline & Peromyscus leucopus (E7-31B) & \\
\hline & Peromyscus leucopus (E8-5B) & \\
\hline & Peromyscus leucopus (E8-6A) & \\
\hline & Peromyscus 1eucopus (E8-7A) & \\
\hline & Blarina brevicauda (E:8-7B) & \\
\hline & Blarina brevicauda (E8-15A) & \\
\hline & Sigmodon hispidus $(E B-15 B)$ & \\
\hline & Blarina brevicauda (E8-15C) & \\
\hline & Peromyscus leucopus (E9-24A) & \\
\hline & Peromyscus leucopus (E9-24B) & \\
\hline & $\overline{\text { Peromyscus }} \overline{\text { leucopus }}$ (E10-16A) & \\
\hline & Blarina brevicauda (E10-16B) & \\
\hline
\end{tabular}

n.d. - not detectable 

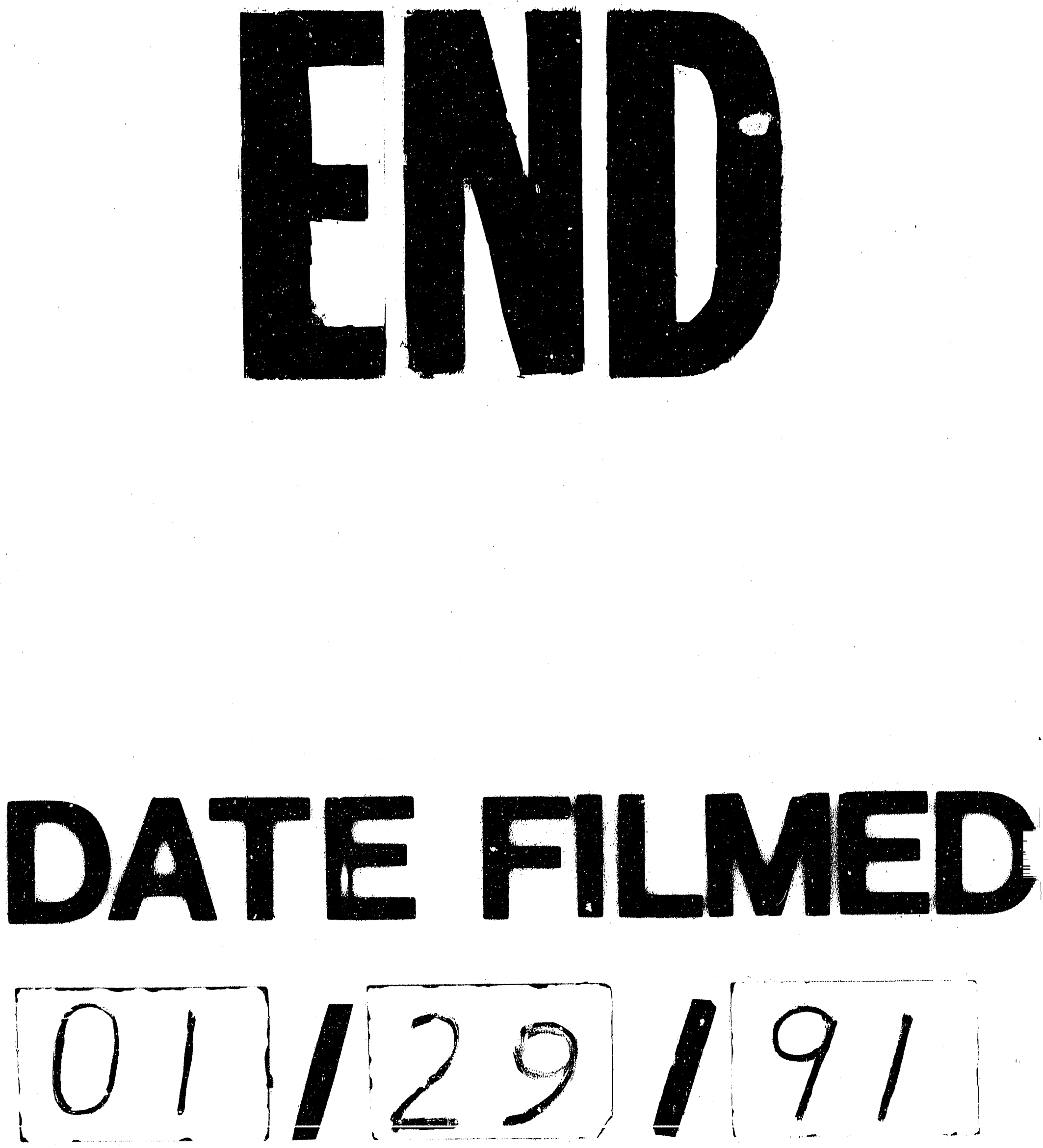


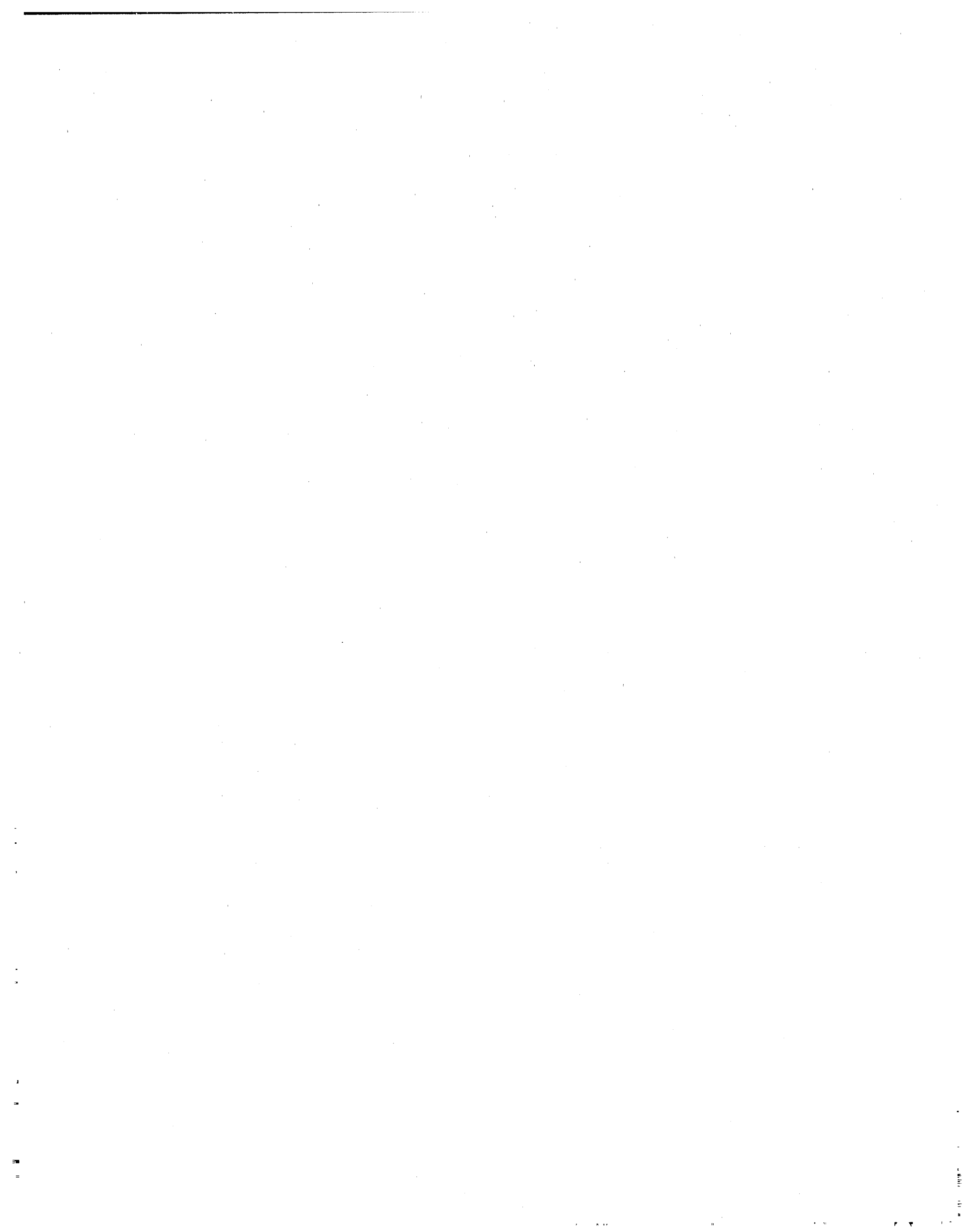

